\author{
UNIVERSIDADE DE SÃO PAULO \\ ESCOLA DE ENGENHARIA DE SÃO CARLOS \\ DEPARTAMENTO DE HIDRÁULICA E SANEAMENTO
}

\title{
ESTRATÉGIAS DE OPERAÇÃO DE REATORES AERÓBIOIANÓXICO OPERADOS EM BATELADA SEQUENCIAL PARA REMOÇÃO DE NITROGÊNIO DE ÁGUA RESIDUÁRIA INDUSTRIAL
}

Eng. Alexandre Fernandes Ono

Dissertação apresentada à Escola de Engenharia de São Carlos, da Universidade de São Paulo, como parte dos requisitos para obtenção do título de Mestre em Engenharia (Hidráulica e Saneamento)

ORIENTADOR: Prof. Dr. Eugenio Foresti

SÃO CARLOS 
AUTORIZO A REPRODUÇÃO E DIVULGAÇÃO TOTAL OU PARCIAL DESTE TRABALHO, POR QUALQUER MEIO CONVENCIONAL OU ELETRÔNICO, PARA FINS DE ESTUDO E PESQUISA, DESDE QUE CITADA A FONTE.

Ficha catalográfica preparada pela Seção de Tratamento da Informação do Serviço de Biblioteca - EESC/USP

$058 \mathrm{~d}$

Ono, Alexandre Fernandes

Estratégias de operação de reatores aeróbio/anóxico operados em batelada sequiencial para remoção de nitrogênio de água residuária indústrial / Alexandre Fernandes Ono ; orientador Eugenio Foresti. -- São Carlos, 2007.

Dissertação (Mestrado) - Programa de Pós-Graduação e Área de Concentração em Hidráulica e Saneamento - - Escola de Engenharia de São Carlos da Universidade de São Paulo.

1. Remoção de nitrogênio. 2. Modelo cinético. 3. Microsensores. 4. Efluente industrial. I. Título. 
FOLHA DE JULGAMENTO

Candidato: Engenheiro ALEXANDRE FERNANDES ONO

Dissertação defendida e julgada em 27/07/2007 perante a Comissão Julgadora:

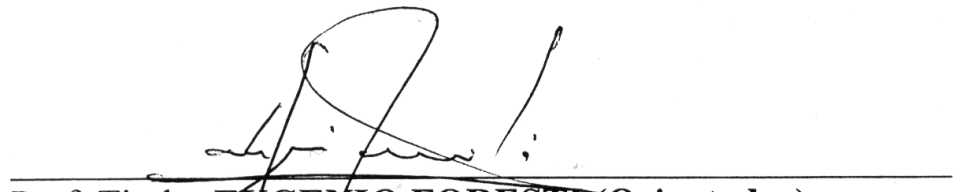

AProd'ABO

Prof. TitularE4GEXIO FORESTT(Orientador)

(Escola de Engenharia de São Carlos/USP)

Fodion P. Silve

Prof. Dr. EDSON LUIZ SILVA

Aprovado

(Universidade Federal de São Carlos/UFSCar)

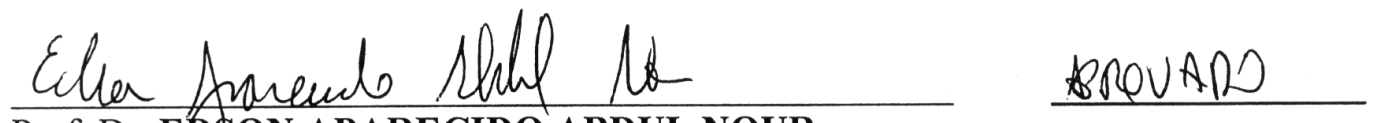

Prof. Dr. EDSON APARECIDO ABDUL NOUR

(Universidade Estadual de Campinas/UNICAMP)

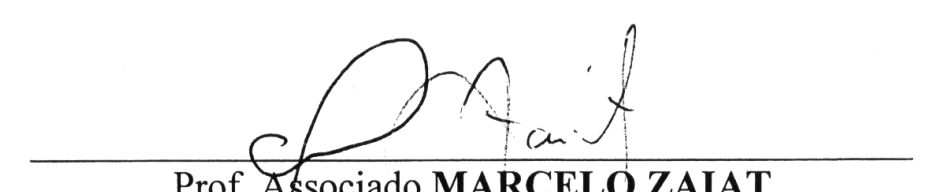

Prof. Associado MARCELO ZAIAT

Coordenađor do Programa de Pós-Graduação

em Engenharia (Hidráulica e Saneamento)

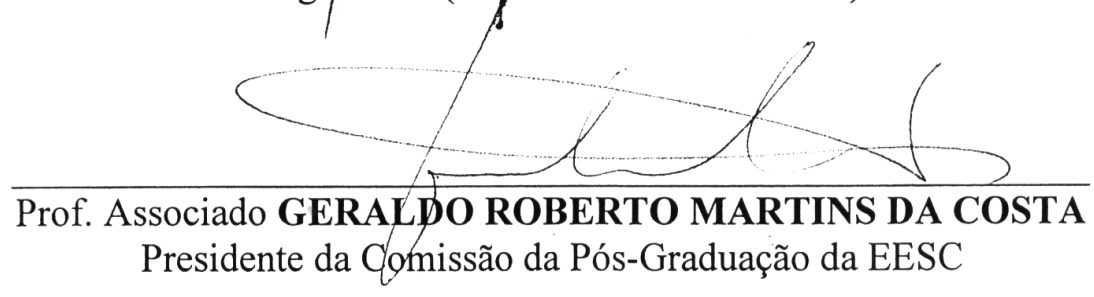





\section{Agradecimentos}

Ao Prof. Dr. Eugenio Foresti pela orientação e oportunidade de desenvolver este trabalho.

Ao CNPq, pela bolsa de estudo concedida.

Aos colegas do programa de pós-graduação e do Laboratório de Processos Biológicos, pela convivência, aprendizado e colaboração na realização da pesquisa e aos momentos agradáveis no café...

Em especial ao Arnaldo, Beth, Janja, Elô, Wagner, Dani, Renata, Tiago, Bruna, Cris, Renato, pelo incentivo, sugestões e apoio ao longo do trabalho e pela amizade.

Às secretárias Rose, Sá e Paví.

A todos amigos, colegas e familiares que me apoiaram diretamente e indiretamente nesta etapa da minha vida ...

À Juliana pelo carinho, atenção e incentivo.

... aos meus pais, Ruth e Ono e à minha irmã Andréa, pelo carinho, apoio, incentivo, paciência, ...

A DEUS pelo dom da vida! 


\section{Sumário}

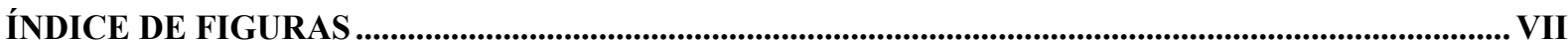

ÍNDICE DE TABELAS ....................................................................................................................III

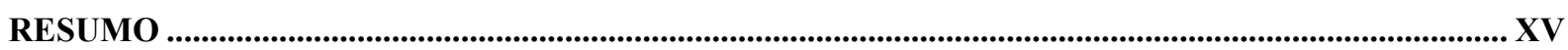

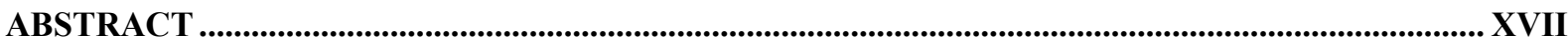

\section{Capítulo 1 - Introdução e Objetivos}

1.1. INTRODUÇÃO

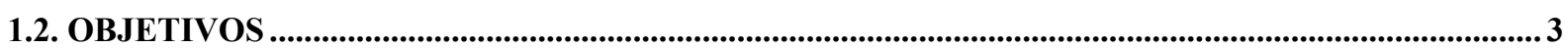

\section{Capítulo 2 - Revisão da Literatura}

2.1. PROCESSOS CONVENCIONAIS PARA REMOÇÃO DE NITROGÊNIO ............................................5

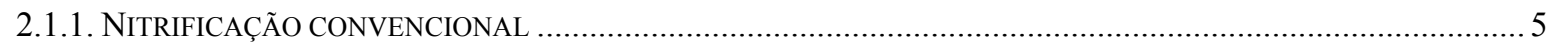

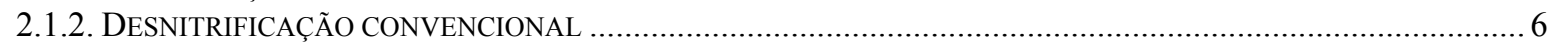

2.2. NOVOS PROCESSOS DE REMOÇÃO BIOLÓGICA DE NITROGÊNIO …......................................... 7

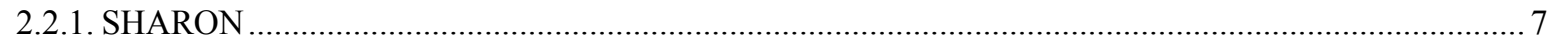

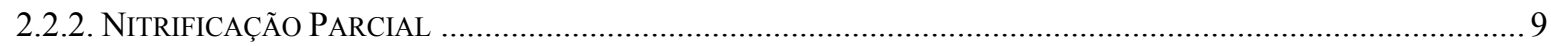

2.2.3. NITRIFICAÇÃO E DESNITRIFICAÇÃO SIMULTÂNEA - SND ………..........................................................

2.2.4. ANAMMOX

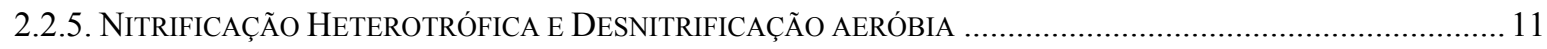

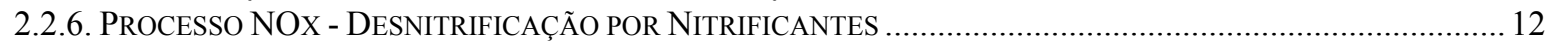

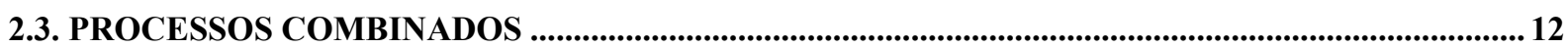

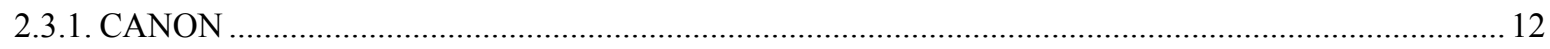

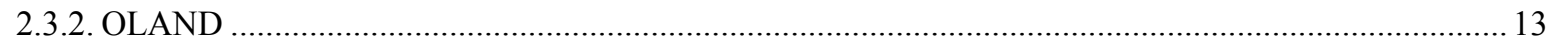

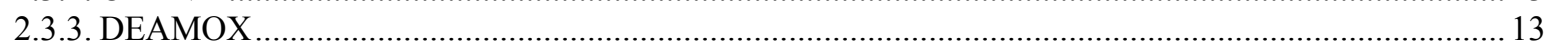

2.4. DESNITRIFICAÇÃO AUTOTRÓFICA UTILIZANDO COMPOSTOS DE ENXOFRE.....................14

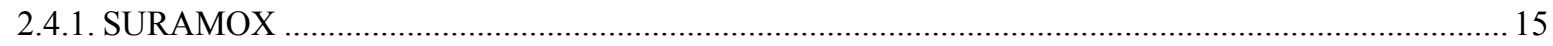

\section{Capítulo 3 - Material e Métodos}

3.1. VISÃO GERAL DO PROCEDIMENTO EXPERIMENTAL................................................................. 17

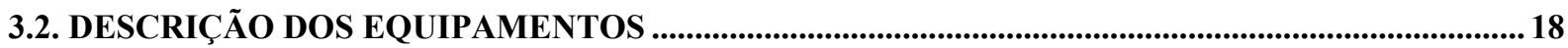

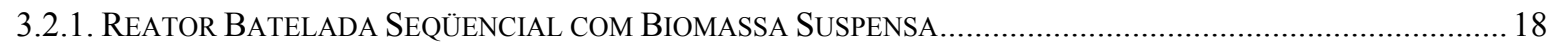

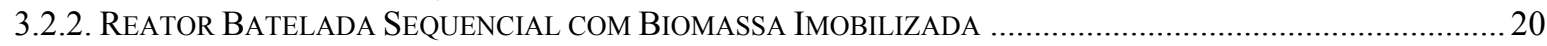

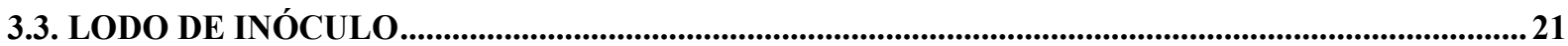

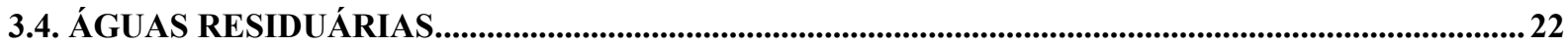

3.5. PROCEDIMENTO EXPERIMENTAL - DESCRIÇÃO DA OPERAÇÃO ............................................ 25

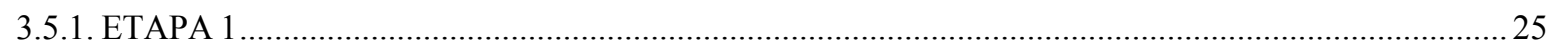

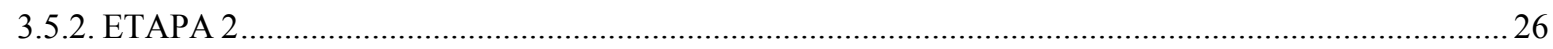




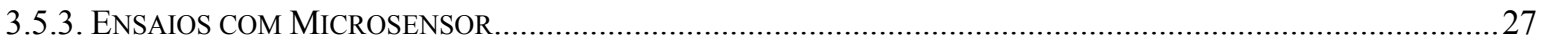

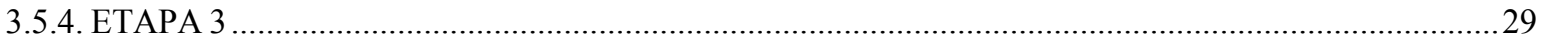

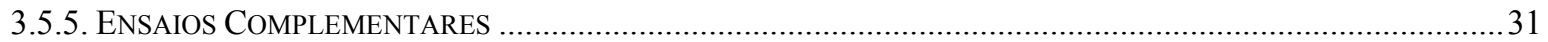

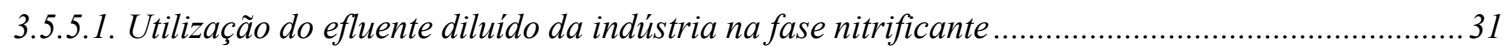

3.5.5.2. Verificação da nitrificação e do possível processo anammox sem interferentes ............................. 31

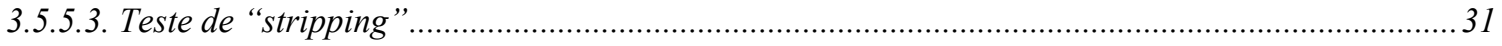

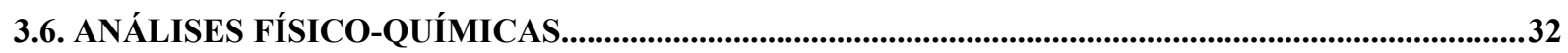

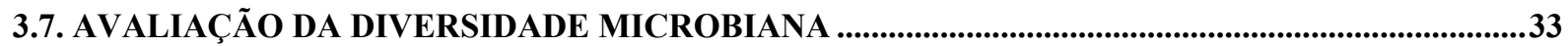

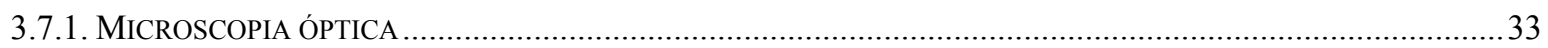

3.7.2. MICROSCOPIA ELETRÔNICA DE VARREDURA

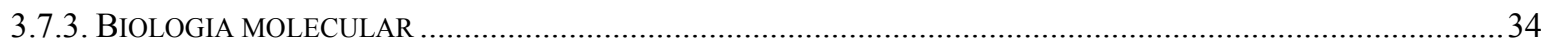

\section{Capítulo 4 - Resultados e Discussão}

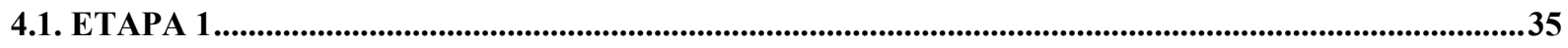

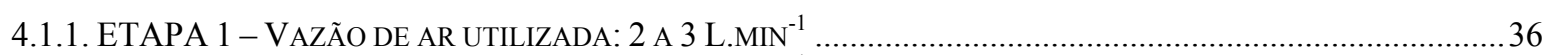

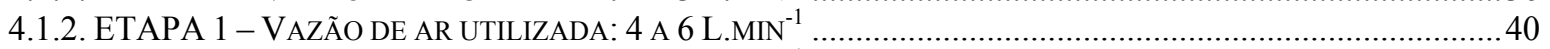

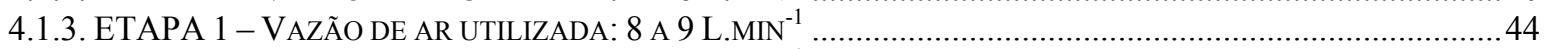

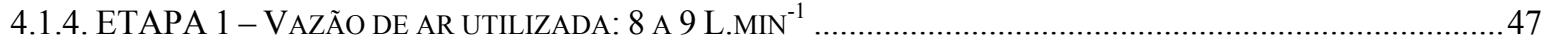

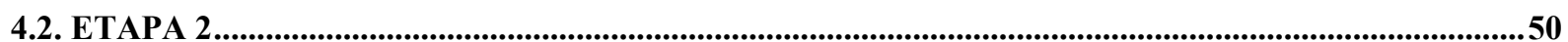

4.2.1. AJUSTE DA AERAÇÃO PARA O PROCESSO NITRIFICANTE …...................................................................51

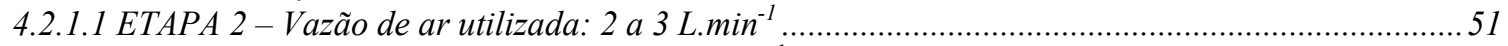

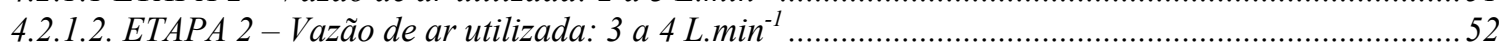

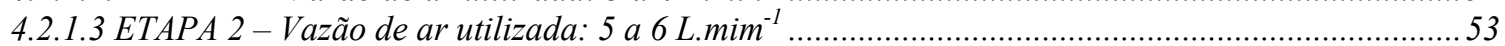

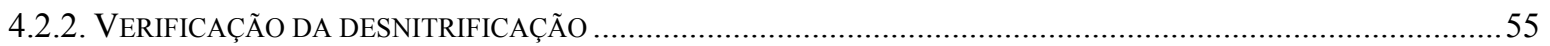

4.2.2.1. ETAPA 2 - Adição de afluente na fase anóxica proveniente de reator metanogênico ...................56

4.2.2.2 ETAPA 2 - Adição de afluente na fase anóxica proveniente de reator sulfetogênico..................... 61

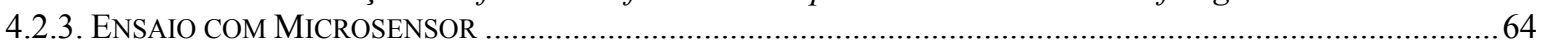

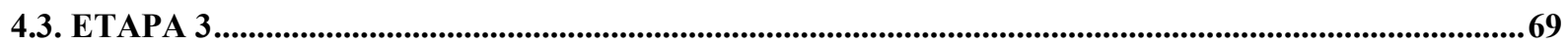

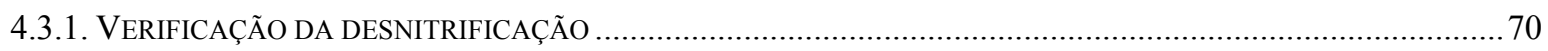

4.3.1.1. ETAPA 3-Adição de afluente na fase anóxica proveniente de reator metanogênico .....................70

4.3.1.2. ETAPA 3 - Adição de afluente na fase anóxica proveniente de reator sulfetogênico......................74

4.3.1.3. ETAPA 3 - Adição de afluente na fase anóxica proveniente de reator sulfetogênico...................... 78

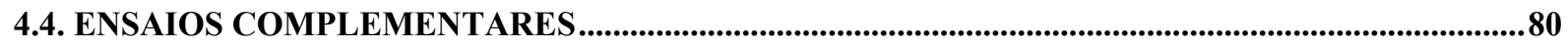

4.4.1. UTILIZAÇÃO DO EFLUENTE ORIGINAL DA INDÚSTRIA DILUÍDO NA FASE NITRIFICANTE.............................80

4.4.2. VERIFICAÇÃO DA NITRIFICAÇÃO E DO POSSÍVEL PROCESSO ANAMMOX SEM INTERFERENTES ..................81

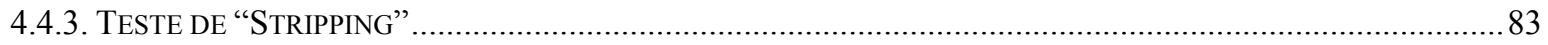

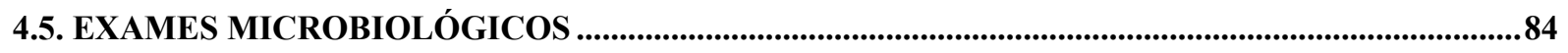

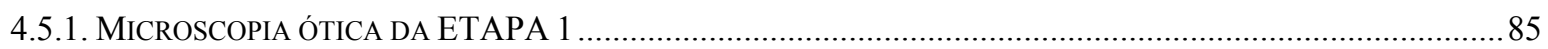

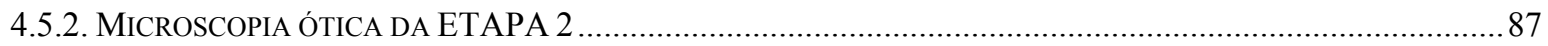

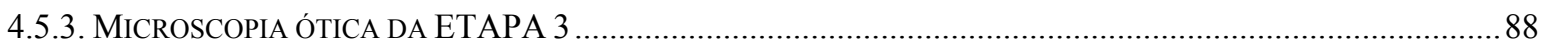

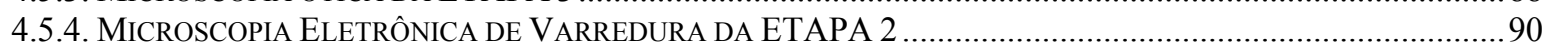

4.5.5. MicROSCOPIA ELETRÔNICA DE VARREDURA DA ETAPA 3 ...............................................................91

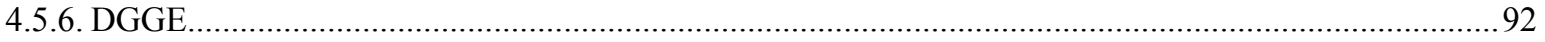

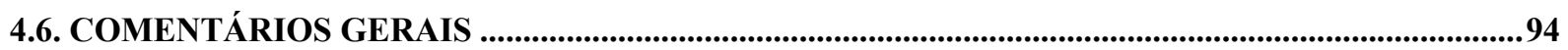

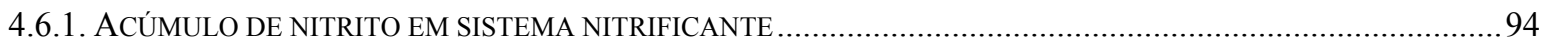

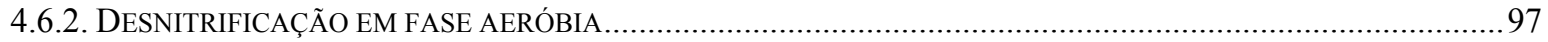

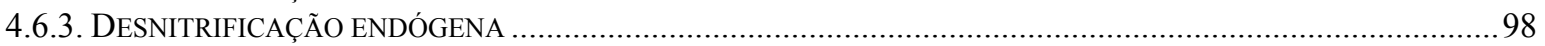

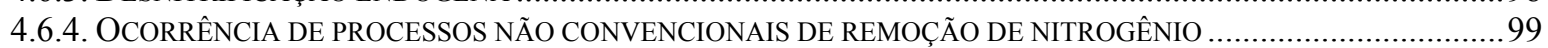

4.6.5. UTILIZAÇÃO DE COMPOSTOS DE ENXOFRE PARA O PROCESSO DE DESNITRIFICAÇÃO AUTOTRÓFICA........102 


\section{Capítulo 5 - Conclusões}

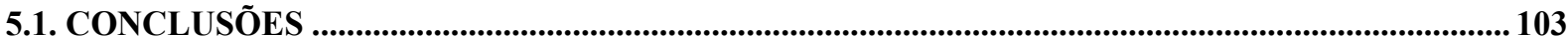

\section{Capítulo 6 - Referências}

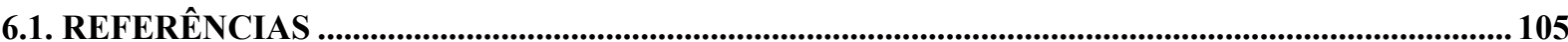




\section{Índice de Figuras}

Figura 1: Vantagem da remoção de nitrogênio via nitrito.

Figura 2: Relação entre a temperatura e o tempo mínimo de retenção celular, para as bactérias nitrificantes do gênero Nitrossomonas e Nitrobacter. Adaptado de Mulder e van Kemper, (1997).

Figura 3: Representação de biofilme em suporte inerte com gradiente de oxigênio dissolvido formando zonas aeradas e anóxicas. Adaptado de "Applications of Cell Immobilization Biotechnology - NEDOVIĆ e WILLAERT (2005)”.

Figura 4: Fluxograma do conceito do processo DEAMOX. 14

Figura 5: Fluxograma do procedimento experimental. 18

Figura 6: Instalação experimental utilizada para as Etapas 1 e 2.

Figura 7: Detalhes do reator utilizado para as Etapas 1 e 2 (IAMAMOTO, 2006). 20

Figura 8: Instalação experimental e detalhes do reator utilizado na Etapas 3. 21

Figura 9: Esquema simplificado da produção de óleo sulfonado. .22

Figura 10: Reator sulfetogênico 24

Figura 11: Reator metanogênico ${ }^{2}$ 24

Figura 12: Representação gráfica do ciclo da Etapa 1 25

Figura 13: Representação gráfica do ciclo da Etapa 2 . 26

Figura 14: Desenho esquemático do reator tipo célula de fluxo. 28

Figura 15: Materiais suportes fixados na célula de fluxo. 28

Figura 16: Montagem experimental do reator tipo célula tipo fluxo para aplicação de ensaios com microsensor.. 28

Figura 17: Preparação para a realização do ensaio com microsensor. 29

Figura 18: Ensaio de microsensor em andamento. 29

Figura 19: Representação gráfica do ciclo da Etapa 3 30

Figura 20: Aparato utilizado para o teste de "Stripping". 32 
Figura 21: Perfil temporal de 24 horas de compostos de nitrogênio realizado na Etapa 1 com vazão de ar aplicado no sistema de 2 a 3 L. $\mathrm{min}^{-1}$.

Figura 22: Esquema do modelo convecional para remoção de nitrogênio proposto.

Figura 23: Perfil temporal de 24 horas de ácidos orgânicos realizado na Etapa 1 com vazão de ar aplicado no sistema de 2 a 3 L.min ${ }^{-1}$

Figura 24: Perfil temporal de 24 horas de compostos de nitrogênio realizado na Etapa 1 com vazão de ar aplicado no sistema de 4 a 6 L.min ${ }^{-1}$

Figura 25: Perfil temporal de 24 horas de compostos $\mathrm{pH}$ e potencial Redox realinado na Etapa 1 com vazão de ar aplicado no sistema de 4 a 6 L.min ${ }^{-1}$

Figura 26: Perfil temporal de 24 horas de ácidos orgânicos realizado na Etapa 1 com vazão de ar aplicado no sistema de 4 a 6 L.min ${ }^{-1}$

Figura 27: Perfil temporal de 24 horas de compostos de nitrogênio realizado na Etapa 1 com vazão de ar aplicado no sistema de 8 a 9 L.min ${ }^{-1}$

Figura 28: Perfil temporal de 24 horas de ácidos orgânicos realizado na Etapa 1 com vazão de ar aplicado no sistema de 8 a 9 L.min ${ }^{-1}$

Figura 29: Duplicata do perfil temporal de 24 horas de compostos de nitrogênio realizado na Etapa 1 com vazão de ar aplicado no sistema de 8 a 9 L.min ${ }^{-1}$

Figura 30: Duplicata do perfil temporal de 24 horas de ácidos orgânicos realizado na Etapa 1 com vazão de ar aplicado no sistema de 8 a 9 L.min ${ }^{-1}$.....

Figura 31: Ajuste da aeração para o processo nitrificante na Etapa 2. Vazão de ar utilizada de 2 a 3 L.min ${ }^{-1}$ 51

Figura 32: Ajuste da aeração para o processo nitrificante na Etapa 2. Vazão de ar utilizada de 3 a 4 L.min ${ }^{-1}$ 53

Figura 33: Ajuste da aeração para o processo nitrificante na Etapa 2. Vazão de ar utilizada de 5 a 6 L.min ${ }^{-1}$ 54

Figura 34: Perfil temporal de compostos de enxofre realizado conjuntamente com o ajuste da aeração para o processo nitrificante na Etapa 2. Vazão de ar utilizada de 5 a 6 L. $\min ^{-1}$ 55

Figura 35: Verficação da desnitrificação na Etapa 2 com adição de afluente na fase anóxica proveniente de reator metanogênico.... 56

Figura 36: Esquema do modelo cinético adotado englobando a possibilidade de ocorrência da ANAMMOX.

Figura 37: Acompanhamento dos compostos de enxofre na fase anóxica da Etapa 2 com adição de afluente proveniente de reator metanogênico 
Figura 38: Acompanhamento de ácidos orgânicos na fase anóxica da Etapa 2 com adição de afluente proveniente de reator metanogênico.

Figura 39: Acompanhamento do $\mathrm{pH}$ e do potencial Redox na fase anóxica da Etapa 2 com adição de afluente proveniente de reator metanogênico.

Figura 40: Verficação da desnitrificação na Etapa 2 com adição de afluente na fase anóxica proveniente de reator sulfetogênico

Figura 41: Acompanhamento de ácidos orgânicos na fase anóxica da Etapa 2 com adição de afluente proveniente de reator sulfetogênico.

Figura 42: Resultados de diversos ensaios com microsensor em biofilmes. Relação da profundidade com a concentração de oxigênio dissolvido

Figura 43: Foto do material suporte Carvão Mineral. 66

Figura 44: Foto do material suporte Carvão Vegetal. 66

Figura 45: Foto do material suporte Espuma de Poliuretano. 66

Figura 46: Foto do material suporte Discos Plásticos. (Polietileno) .66

Figura 47: Foto do material suporte Polietileno de Baixa Densidade. .66

Figura 48: Foto do material suporte Brita Basáltica. 66

Figura 49: Perfil de oxigênio em biofilme. Material suporte - Brita Basáltica. .67

Figura 50: Perfil de oxigênio em biofilme. Material suporte - Carvão Mineral 67

Figura 51: Perfil de oxigênio em biofilme. Material suporte - Carvão Vegetal.

Figura 52: Perfil de oxigênio em biofilme. Material suporte-Disco Plástico.

Figura 53: Perfil de oxigênio em biofilme. Material suporte -Polietileno de Baixa Densidade. 68

Figura 54: Perfil de oxigênio em biofilme. Material suporte -Espuma de Poliuretano. 68

Figura 55: Comparação entre as espessuras dos biofilmes nos diferentes suportes. 68

Figura 56: Verficação da desnitrificação na Etapa 3 com adição de afluente na fase anóxica proveniente de reator metanogênico.

Figura 57: Acompanhamento dos compostos de enxofre na fase anóxica da Etapa 3 com adição de afluente proveniente de reator metanogênico. 73 
Figura 58: Acompanhamento de ácidos orgânicos na fase anóxica da Etapa 3 com adição de afluente proveniente de reator metanogênico

Figura 59: Verficação da desnitrificação na Etapa 3 com adição de afluente na fase anóxica proveniente de reator sulfetogênico ............................................................ 75

Figura 60: Acompanhamento dos compostos de enxofre na fase anóxica da Etapa 3 com adição de afluente proveniente de reator sulfetogênico

Figura 61: Acompanhamento de ácidos orgânicos na fase anóxica da Etapa 3 com adição de afluente proveniente de reator sulfetogênico 77

Figura 62: Verficação da desnitrificação na Etapa 3 com adição de afluente na fase anóxica proveniente de reator sulfetogênico.

Figura 63: Acompanhamento de ácidos orgânicos na fase anóxica da Etapa 3 com adição de afluente proveniente de reator sulfetogênico 79

Figura 64: Utilização do efluente original da indústria diluído na fase nitrificante 80

Figura 65: Verificação da nitrificação e do possível processo anammox sem interferentes na fase aeróbia e anóxica 82

Figura 66: Teste de "Stripping". 84

Figura 67: Morfologias encontradas no reator de biomassa suspensa na Etapa 1. (1) Cocobacilos coloniais com inclusões; (2) Filamentos e bacilos com inclusões e sem inclusões; (3) Bacilos com inclusões e cocos; (4) Aglomerado de bactérias semelhantes à 'Clusters' ANAMMOX; (5) Cocos semelhantes à nitrosococcus (maior); (6) Filamentos, bacilos com inclusões; (7) Filamentos, bacilos com inclusões e cocos em tétrade semelhantes à bactérias ' $\mathrm{G}^{\prime}$; (8) Cocos em tétrade semelhantes à bactérias ' $\mathrm{G}$ '. 86

Figura 68: Microscopia óptica de contraste de fase na Etapa 2 do reator com biomassa suspensa. (1) Cocos semelhantes à nitrosococcus; (2) Filamentos com inclusões semelhantes à nostocoida limicola; (3) Cocobacilos coloniais com inclusões; (4) Aglomerado de cocos envolto por membrana semelhantes à 'Clusters' ANAMMOX; (5) Aglomerados de bacilos e cocos; (6) Aglomerado de microganismos envolto por membrana semelhantes à 'Clusters' ANAMMOX; (7) Bacilos semelhantes à bacterias fototróficas anoxigênicas; (8) Filamentos septados, bacilos com inclusões e bactérias ' $\mathrm{G}$ '. 88

Figura 69: Microscopia óptica de contraste de fase na Etapa 3 do reator com biomassa imobilizada. (1) Bacilos com inclusões; (2) Bacilos com inclusões de enxofre; (3) Cocos semelhantes à Nitrosococcus; (4) Filamentos septados com inclusões, bacilos com inclusões diversas; (5) Cocos semelhantes à nitrosococcus; (6) Filamentos septados com inclusões semelhantes à Thiothrix.

Figura 70: Microscopia eletrônica de varredura (MEV) de amostras do reator de biomassa suspensa da Etapa 2. (1) Aglomerado de cocos semelhantes às bactérias ANAMMOX; (2) Bacilos e cocos diversos. 90 
Figura 71: Microscopia eletrônica de varredura (MEV) de amostras do reator de biomassa suspensa da Etapa 2. (1) Bacilos diversos; (2) Bacilos e cocos diversos; (3) Bacilos curvos, semelhantes à BRS - Bactéria Redutora de Sulfato; (4) Filamentos septados........................................................................... 91

Figura 72: Fragmentos de DNA amplificados e separados por eletroforese em gel de gradiente desnaturante (DGGE).

Figura 73: Relação entre a concentração de amônia e ácido nitroso e a inibição à bactérias nitrificantes adaptado de Anthonisen et al. (1976)............................................ 96 


\section{Índice de Tabelas}

Tabela 1: Principais compostos e concentrações médias do efluente do reator sulfetogênico e metanogênico.

Tabela 2: Principais características dos reatores sulfetogênico e metanogênico.

Tabela 3: Água residuária sintética utilizada para os ensaios com microsensor. .28

Tabela 4: Parâmetros de análise e métodos utilizados. 33

Tabela 5: Coeficientes cinéticos obtidos pelo modelo convencional de remoção de nitrogênio aplicado à ETAPA 1 - Vazão de ar utilizada: 2 a 3 L.min ${ }^{-1}$

Tabela 6: Coeficientes cinéticos obtidos pelo modelo convencional de remoção de nitrogênio aplicado à ETAPA 1 - Vazão de ar utilizada: 4 a 6 L. $\mathrm{min}^{-1}$.

Tabela 7: Coeficientes cinéticos obtidos pelo modelo convencional de remoção de nitrogênio aplicado à ETAPA 1 - Vazão de ar utilizada: 8 a 9 L.min ${ }^{-1}$

Tabela 8: Coeficientes cinéticos obtidos pelo modelo convencional de remoção de nitrogênio aplicado à ETAPA 1 - Vazão de ar utilizada: 8 a 9 L.min ${ }^{-1}$.

Tabela 9: Coeficientes cinéticos obtidos pelo modelo convencional de remoção de nitrogênio aplicado à ETAPA 2 no ajuste de aeração - Vazão de ar utilizada: 2 a 3 L.min ${ }^{-1}$.

Tabela 10: Coeficientes cinéticos obtidos pelo modelo convencional de remoção de nitrogênio aplicado à ETAPA 2 no ajuste de aeração - Vazão de ar utilizada: 3 a 4 L. $\min ^{-1}$.

Tabela 11: Coeficientes cinéticos obtidos pelo modelo convencional de remoção de nitrogênio aplicado à ETAPA 2 no ajuste de aeração - Vazão de ar utilizada: 5 a 6 L. $\mathrm{min}^{-1}$.

Tabela 12: Coeficientes cinéticos obtidos pelo modelo convencional de remoção de nitrogênio aplicado à ETAPA 2 na fase desnitrificante, com adição de afluente proveniente de reator metanogênico. 56

Tabela 13: Coeficientes cinéticos obtidos pelo modelo não-convencional de remoção de nitrogênio aplicado à ETAPA 2 na fase desnitrificante, com adição de afluente proveniente de reator metanogênico. 58

Tabela 14: Coeficientes cinéticos obtidos pelo modelo convencional de remoção de nitrogênio aplicado à ETAPA 2 na fase desnitrificante, com adição de afluente proveniente de reator sulfetogênico. 
Tabela 15: Coeficientes cinéticos obtidos pelo modelo não-convencional de remoção de nitrogênio aplicado à ETAPA 2 na fase desnitrificante, com adição de afluente proveniente de reator sulfetogênico.

Tabela 16: Coeficientes cinéticos obtidos pelo modelo convencional de remoção de nitrogênio aplicado à ETAPA 3 na fase desnitrificante, com adição de afluente proveniente de reator metanogênico. 71

Tabela 17: Coeficientes cinéticos obtidos pelo modelo não-convencional de remoção de nitrogênio aplicado à ETAPA 3 na fase desnitrificante, com adição de afluente proveniente de reator metanogênico. 72

Tabela 18: Coeficientes cinéticos obtidos pelo modelo convencional de remoção de nitrogênio aplicado à ETAPA 3 na fase desnitrificante, com adição de afluente proveniente de reator sulfetogênico.

Tabela 19: Coeficientes cinéticos obtidos pelo modelo não-convencional de remoção de nitrogênio aplicado à ETAPA 3 na fase desnitrificante, com adição de afluente proveniente de reator sulfetogênico. 76

Tabela 20: Coeficientes cinéticos obtidos pelo modelo convencional de remoção de nitrogênio aplicado à ETAPA 3 na fase desnitrificante, com adição de afluente proveniente de reator sulfetogênico.

Tabela 21: Coeficientes cinéticos obtidos pelo modelo convencional de remoção de nitrogênio aplicado ao ensaio complementar que utiliza efluente original da indústria diluído na fase nitrificante. 81

Tabela 22: Coeficientes cinéticos obtidos pelo modelo convencional de remoção de nitrogênio aplicado ao ensaio complementar para verificação da nitrificação e da desnitrificação do possível processo anammox sem interferentes

Tabela 23: Descrição dos materiais biológicos utilizados para avaliação da comunidade microbiana em DGGE. 92

Tabela 24: Comparação entre similaridade das comunidades microbianas (\%). 93

Tabela 25: Reações teóricas do processo SURAMOX 101 


\section{RESUMO}

ONO, A. F. Estratégias de operação de reatores aeróbio/anóxico operados em batelada seqüencial para remoção de nitrogênio de água residuária industrial. Dissertação (mestrado) Escola de Engenharia de São Carlos, Universidade de São Paulo. São Carlos, 2007.

A pesquisa propôs avaliar o desempenho e o comportamento de reatores seqüenciais em batelada com biomassa suspensa e imobilizada, em escala de bancada, na remoção de compostos de nitrogênio. Tais sistemas foram testados como tratamento complementar de reatores sulfetogênico e metanogênico utilizados no tratamento de água residuária industrial com alta concentração de sulfato e amônia. Visou o desenvolvimento de uma estratégia de operação que viabilizasse o uso dos próprios constituintes da água residuária para a maximização da eficiência do tratamento. $\mathrm{O}$ estudo foi dividido em 3 etapas principais. $\mathrm{Na}$ Etapa 1 (181 dias de operação), o reator com biomassa suspensa foi mantido com 4 fases alternadas aeróbio/anóxico e ciclo de 24 horas, e verificou-se a presença da desnitrificação

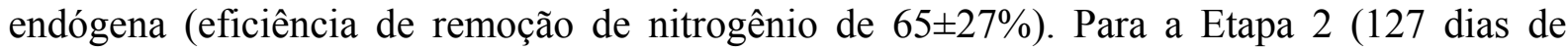
operação), o reator de biomassa suspensa foi submetido ao tempo de ciclo de 12 horas, com uma fase aeróbia (6horas) e com posterior fase anóxica (6 horas). Nessa etapa adicionou-se efluentes dos reatores metanogênico e sulfetogênico, ricos em ácidos voláteis (ácido acético), com intuito de acelerar o processo desnitrificante. Os resultados obtidos foram baixos em termos de remoção de nitrogênio (42 $\pm 21 \%$ ). Para a Etapa 3 (134 dias de operação), foram ensaiados vários meios suportes, através de técnica de microsensores de oxigênio dissolvido, a fim de verificar a formação de biofilme específico (nitrificante/desnitrificante) e optou-se pelo uso do carvão mineral no reator com biomassa imobilizada. Nesta última etapa, foi mantida a estratégia operacional adotada na Etapa 2 (ciclo 12 horas), bem como a adição de parcela do afluente na fase anóxica. A remoção de nitrogênio, com períodos aeróbio e anóxico e ciclo de 12 horas, mostrou-se viável no reator com biomassa imobilizada (eficiência de remoção de nitrogênio de $72 \pm 13 \%$ ). Ao final dos ensaios experimentais, realizaram-se modelagens cinéticas que permitiram a compreensão dos processos convencionais e não convencionais ocorridos nas várias etapas para remoção de nitrogênio, tais como desnitrificação em fase aeróbia e o processo ANAMMOX.

Palavras-chave: Remoção de Nitrogênio. Modelo Cinético. Microsensores. Efluente Industrial. 


\begin{abstract}
ONO, A. F. Strategies of operation of aerobic/anoxic sequential batch reactors for industrial wastewater nitrogen removal. Dissertação (mestrado) - Escola de Engenharia de São Carlos, Universidade de São Paulo. São Carlos, 2007.

The purpose of this research was to evaluate the performance and the behavior of sequential batch reactors with suspended and immobilized biomass, in benches scale, for the nitrogen composite removal. Such systems had been tested as sulphetogenic and methanogenic reactors complementary treatment, used in an industrial waste water treatment with high sulphate and ammonia concentrations. The research aimed for the development of an operation strategy that could make possible the use of the proper waste water constituent for the improvement of the treatment efficiency. The study was divided into 3 main stages. In Stage 1 (181 days of operation), the reactor with suspended biomass was kept with 4 alternating phases aerobic/anoxic and a 24-hour cycle was used, and the endogenous

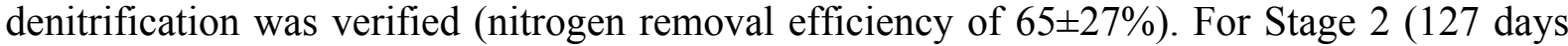
of operation), the suspended biomass reactor was submitted to a cycle of 12 hours, with an aerobic phase (6 hours) and posterior anoxic phase (6 hours). In this stage effluent of the methanogenic and sulphetogenic reactors, rich in volatile acid (acetic acid), was added to accelerate the denitrify process. The achieved results had been low in terms of nitrogen removal $(42 \pm 21 \%)$. For Stage 3 (134 days of operation), some supports media was tested through dissolved oxygen microsensors technique, in order to check the specific biofilm formation (nitrificant/denitrificant) and the mineral coal was opted to be used in the immobilized biomass reactor. In this last stage it was adopted an operational strategy similar in Stage 2 (12 hours cycle), as well as the addition of part of the affluent in the anoxic phase. The nitrogen removal, with aerobic and anoxic periods and 12 hours cycle, revealed feasible in the reactor with immobilized biomass (nitrogen removal efficiency of $72 \pm 13 \%$ ). In the end of the experimental tests, kinetic modelings were done and had allowed the understanding of conventional and not conventional processes occurred in the stages for nitrogen removal, such as desnitrification in aerobic phase and ANAMMOX process.
\end{abstract}

Key-Words: Nitrogen Removal. Kinetic Model. Microsensor. Industrial Waste Water. 


\section{Capítulo 1}

\section{Introdução e Objetivos}

\subsection{INTRODUÇÃO}

A adequação de efluentes industriais e domésticos aos padrões de lançamento, determinados por lei, exige a remoção de compostos potencialmente poluidores. Compostos como nitrogênio e fósforo, se não removidos, podem causar eutrofização e como conseqüência podem causar a mortandade de organismos aquáticos.

Os processos usualmente conhecidos para remoção de nutrientes, especialmente o nitrogênio, são os processos físico-químicos e os processos biológicos. Suas aplicações estão condicionadas à concentração de nitrogênio amoniacal do efluente. Segundo Mulder (2003), os processos biológicos são viáveis para concentrações de nitrogênio amoniacal de até 5000 $\operatorname{mgN}-\mathrm{NH}_{4}{ }^{+} \cdot l^{-1}$. Para concentrações superiores à essas são viáveis os processos físicos químicos, tais como 'Stripping' da amônia e a precipitação de $\mathrm{MgNH}_{4} \mathrm{PO}_{4}$.

Convencionalmente, nos processos biológicos para remoção de nitrogênio, utilizam-se a nitrificação e a desnitrificação em reatores aeróbios e anóxicos, respectivamente. $\mathrm{O}$ nitrogênio amoniacal é oxidado à nitrato na fase aeróbia e posteriormente reduzido na fase anóxica com o auxílio de fontes exógenas de carbono. A integração dos processos nitrificantes e desnitrificantes em um único pode tornar-se um processo interessante tendo em vista a diminuição dos custos para implementação do sistema terciário.

Recentemente, novos processos para remoção estão sendo estudados e apresentam muitas vantagens em relação aos tradicionais para remoção biológica de nutriente. A remoção via nitrito é um processo muito interessante, pois se pode economizar oxigênio e alcalinidade para nitrificação e fonte externa de carbono para o processo de desnitrificação heterotrófica. Outro processo que é digno de atenção é o processo ANAMMOX que utiliza o nitrito como aceptor de elétrons e utiliza o nitrogênio amoniacal como fonte de energia e não necessita de fonte adicional de carbono.

Entre trabalhos realizados no Laboratório de Processos Biológicos da Escola de Engenharia de São Carlos da Universidade de São Paulo, sobre remoção de elevadas 
concentrações de nitrogênio em reatores sequenciais em batelada, que contribuíram para a realização deste trabalho, destacam-se os trabalhos de Daniel (2005) e Iamamoto (2006).

Daniel (2005) operou reator seqüencial em batelada com biomassa imobilizada e aeração intermitente para remoção de nitrogênio de efluente sintético. Testou diferentes concentrações de nitrogênio amoniacal afluentes (40, 125, 250 e $\left.500 \mathrm{mgN} . l^{-1}\right)$ e obteve como produto principal do processo nitrificante o nitrito e nas fases anóxicas foi verificado a desnitrificação. Iamamoto (2006) testou diferentes concentrações de nitrogênio amoniacal, que variou de 125 a $500 \mathrm{mgN} . l^{-1}$, em reator com biomassa suspensa operado em batelada seqüencial com aeração intermitente. Com $125 \mathrm{mgN} . l^{-1}$ o produto principal da nitrificação foi nitrato e na condição de $250 \mathrm{mgN} . l^{-1}$ o nitrito foi o principal produto das fases aeróbias e foi verificado a nitrificação e a desnitrificação simultânea em fase aeróbia.

Neste trabalho, a água residuária industrial, objeto desta pesquisa, apresentava altas concentrações de nitrogênio amoniacal e sulfalto. Foi utilizado um reator sulfetogênio para reduzir o sulfato presente e em seguida um reator metanogênico para eliminação da carga orgânica gerada no processo biológico de redução de sulfato. No entanto, a concentração de nitrogênio amoniacal afluente era semelhante à do efluente, necessitando efetiva remoção de nitrogênio deste efluente industrial. Diante desta problemática, optou-se por realizar a remoção biológica do nitrogênio deste efluente industrial complexo em um único reator aeróbio/anóxico em batelada sequencial e verificar qual a melhor estratégia operacional para alcançar os objetivos traçados. 


\subsection{OBJETIVOS}

O objetivo desta pesquisa foi avaliar o desempenho e comportamento de reatores sequenciais em batelada, aeróbio/anóxico biológicos, para remoção de compostos de nitrogênio. Foram utilizados reatores em bateladas sequenciais com ciclos aeróbios/anóxicos e almejou-se a melhor configuração e condição operacional para o tratamento biológico destinado a promover a nitrificação e a desnitrificação. Visou o desenvolvimento de uma estratégia de operação que viabilizasse o uso dos próprios constituintes da água residuária industrial para a maximização da eficiência do tratamento.

Os objetivos específicos foram:

- Avaliar a desnitrificação endógena;

- Verificar as melhores estratégias de operação com relação às fases aeróbias e anóxica e os respectivos tempos de duração;

- Avaliar a adição de uma parte do afluente para o processo desnitrificante;

- Avaliar o melhor meio suporte para o reator nitrificante/desnitrificante através de técnicas de microsensores;

- Modelagem cinética da nitrificação e desnitrificação dos dois reatores;

- Comparação entre reatores com biomassa suspensa e biomassa imobilizada; 


\section{Capítulo 2}

\section{Revisão da Literatura}

\subsection{PROCESSOS CONVENCIONAIS PARA REMOÇÃO DE NITROGÊNIO}

\subsubsection{Nitrificação convencional}

A nitrificação é um processo aeróbio realizado por microorganismos Gram-negativos litoautótrofos pertencente à família Nitrobacteriaceae, que não são esporulados e podem ser esféricos, bacilares ou espiralados (GÓMEZ-HERNÁNDEZ et al., 1995; PROSSER et al., 1989). Este processo consiste na oxidação de formas reduzidas de nitrogênio inorgânico $\left(\mathrm{NH}_{4}{ }^{+}\right.$e $\left.\mathrm{NH}_{3}\right)$ a nitrito $\left(\mathrm{NO}_{2}{ }^{-}\right)$e nitrato $\left(\mathrm{NO}_{3}{ }^{-}\right)$e é catalisada por dois grupos distintos de bactérias: Oxidadoras de amônia, que oxidam amônia, e não amônio, a nitrito e as que oxidam nitrito, levando à nitrato. Ambos os grupos utilizam-se de vias não assimilativas para se obter energia para crescimento e manutenção celular (MADIGAN et al., 1997).

Para esses microorganismos, a fonte de carbono é inorgânica, geralmente $\mathrm{CO}_{2}$, e a energia é obtida por meio da oxidação destes substratos inorgânicos. Em sistemas de tratamento de efluentes, a contribuição de organismos heterótrofos na nitrificação pode ser considerada desprezível (VAN LOOSDRECHT e JETTEN, 1998).

Os dois principais gêneros de bactérias atuantes nesses processos são Nitrossomosas e Nitrobacter, sendo essas bactérias aeróbias obrigatórias (VAN HAANDEL e MARAIS, 1999). Utilizam preferencialmente o $\mathrm{CO}_{2}$ como fonte de carbono. A temperatura ótima de operação destes microrganismos é de $30^{\circ} \mathrm{C}$ a $35^{\circ} \mathrm{C}$, com faixa de $\mathrm{pH}$ ótimo para nitrificação entre 7 e 9 (HENZE et al., 1997).

A nitrificação pode ser descrita como:

$2 \mathrm{NH}_{3}+3 \mathrm{O}_{2} \stackrel{\text { Nitrosomonas }}{\longrightarrow} 2 \mathrm{NO}_{2}{ }^{-}+3 \mathrm{H}^{+}+2 \mathrm{H}_{2} \mathrm{O} \quad \Delta \mathrm{G}^{\mathbf{o}}=-384 \mathrm{~kJ}$ 
A equação geral é descrita como:

$$
\mathrm{NH}_{3}+2 \mathrm{O}_{2} \longrightarrow \mathrm{NO}_{3}^{-}+\mathrm{H}_{2} \mathrm{O}+\mathrm{H}^{+} \quad \Delta \mathrm{G}^{\mathbf{o}}=-268 \mathrm{~kJ}
$$

Nota-se que o processo nitrificante não remove nitrogênio da água residuária, apenas muda o estado de oxidação dos compostos de nitrogênio. Como é um processo acidificante, observa-se uma grande quantidade de alcalinidade consumida, podendo afetar o $\mathrm{pH}$ e a estabilidade do sistema. Teoricamente, $8,64 \mathrm{mg}$ de alcalinidade na forma de bicarbonato $\left(\mathrm{HCO}_{3}{ }^{-}\right)$são consumidos para cada $1 \mathrm{mg}$ de nitrogênio, na forma de amônia, oxidado.

\subsubsection{Desnitrificação convencional}

A desnitrificação é a conversão biológica do nitrogênio, na forma de nitrato e nitrito, a formas mais reduzidas, como $\mathrm{NO}, \mathrm{N}_{2} \mathrm{O}$ e $\mathrm{N}_{2}$ (ROS, 1995). As rotas bioquímicas utilizadas são idênticas àquelas envolvidas na respiração, exceto pelo aceptor de elétrons que, na desnitrificação, é o nitrato. A desnitrificação ocorre em meio onde a concentração de oxigênio dissolvido é igual ou muito próxima de zero, estabelecendo condições anóxicas devidas à presença de nitrato no meio líquido.

Os passos da redução dissimilativa a formas intermediárias gasosas de nitrogênio, são mostrados :

$$
\mathrm{NO}_{3}{ }^{-} \longrightarrow \mathrm{NO}_{2}{ }^{-} \longrightarrow \mathrm{NO} \longrightarrow \mathrm{N}_{2} \mathrm{O} \longrightarrow \mathrm{N}_{2}
$$

Os três últimos produtos são liberados na forma gasosa, mas somente a redução a $\mathrm{N}_{2}$ é capaz de evitar os prejuízos decorrentes da presença de compostos nitrogenados no meio líquido.

A manutenção de baixas concentrações de oxigênio dissolvido nos sistemas desnitrificantes é importante para que bons níveis de redução de nitrato sejam alcançados. A desnitrificação pode ser melhor na ausência de OD, na faixa de potencial de óxido redução (REDOX) entre $+100 \mathrm{mv}$ e $-100 \mathrm{mv}$. Segundo Pochana e Keller (1999), a eficiência da desnitrificação decresce quando a concentração de OD é superior a $0,2 \mathrm{mgO}_{2} \cdot l^{-1}$. 
Temperatura e $\mathrm{pH}$ representam as condições ambientais mais importantes para o desenvolvimento da desnitrificação. Para van Haandel e Marais (1999), a desnitrificação pode se desenvolver na faixa de temperatura de $7^{\circ} \mathrm{C}$ a $40^{\circ} \mathrm{C}$ e, abaixo de $3^{\circ} \mathrm{C}$, nenhuma desnitrificação é observada. Entretanto, na maioria dos estudos de desnitrificação desenvolvidos, a temperatura é mantida na faixa de $20^{\circ} \mathrm{C}$ a $30^{\circ} \mathrm{C}$.

Vários autores afirmam que uma faixa ótima de $\mathrm{pH}$ para a desnitrificação situa-se entre 6,5 e 7,5 e que, em $\mathrm{pH}<6,0$ e $\mathrm{pH}>8,0$, ocorrem diminuições nas atividades de bactérias desnitrificantes.

Com pode se observar na Equação 5 , a desnitrificação é um processo que gera alcalinidade.

$$
2 \mathrm{NO}_{3}^{-}+1,25 \mathrm{CH}_{3} \mathrm{COOH} \longrightarrow 2,5 \mathrm{CO}_{2}+\mathrm{N}_{2}+1,5 \mathrm{H}_{2} \mathrm{O}+2 \mathrm{OH}^{-} \quad \Delta \mathrm{G}^{\mathbf{o}}=-4076 \mathrm{~kJ}
$$

Teoricamente, para cada $1 \mathrm{mg}$ de nitrogênio, na forma de nitrato reduzido, há produção de 4,32 mg de alcalinidade na forma de bicarbonato $\left(\mathrm{HCO}_{3}{ }^{-}\right)$. Comparativamente, observa-se que esta produção de alcalinidade é metade da consumida na etapa de nitrificação.

As bactérias responsáveis pela desnitrificação na sua maioria são heterótrofas. Portanto, utilizam matéria orgânica como fonte de carbono e de energia. O doador de elétrons é fundamental para o processo desnitrificante, pois confere aos microrganismos poder redutor sobre o aceptor de elétrons, que são os compostos oxidados de nitrogênio como o nitrato e nitrito.

\subsection{NOVOS PROCESSOS DE REMOÇÃO BIOLÓGICA DE NITROGÊNIO}

\subsubsection{SHARON}

O processo SHARON ("Single-reactor High-activity Ammonium Removal Over Nitrite"), baseia-se na oxidação parcial de amônia à nitrito. A principal vantagem desse processo é a eliminação da etapa de oxidação de nitrito a nitrato (nitratação) e da etapa de redução de nitrato a nitrito, resultando em redução significativa dos custos operacionais devido a dois fatores: redução do consumo de energia, pela diminuição do consumo de oxigênio na etapa aeróbia e redução da demanda por fonte de carbono exógeno, necessária na etapa de desnitrificação. Conforme o Figura 1 , são mostradas as vantagens do processo SHARON. 


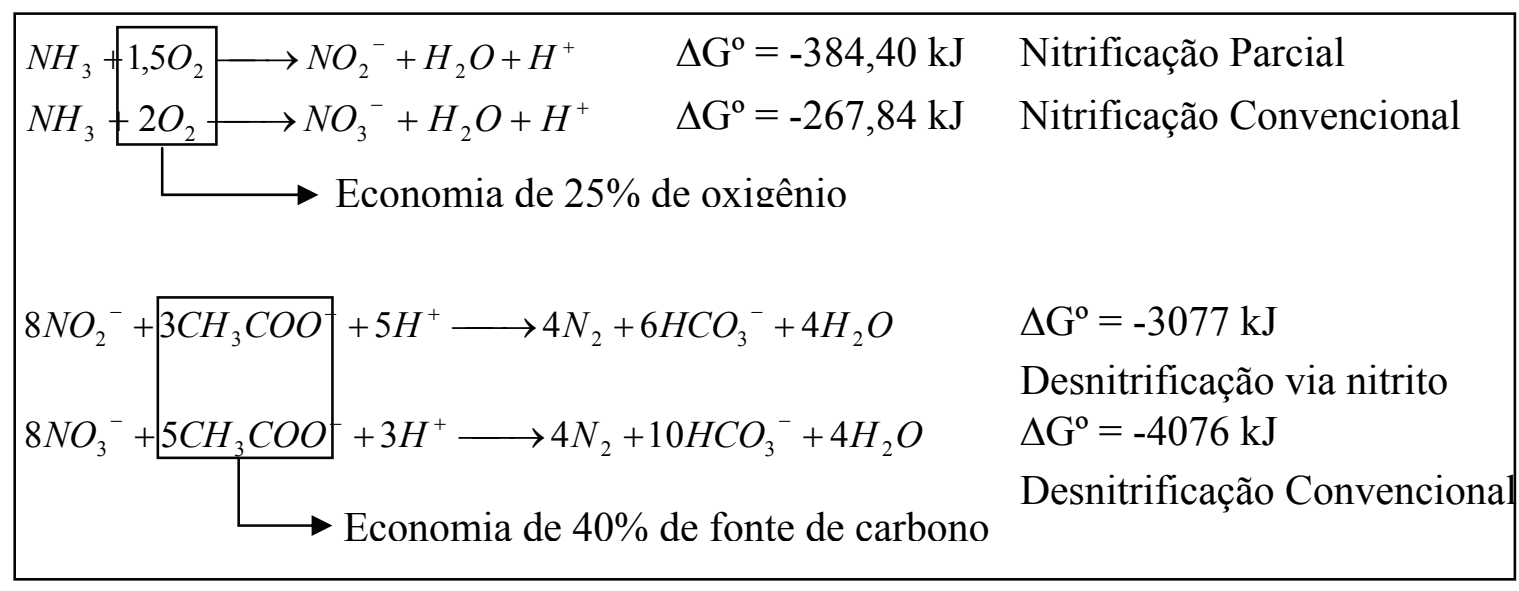

Figura 1: Vantagem da remoção de nitrogênio via nitrito.

Hunik et al. (1993) verificaram que bactérias oxidadoras de amônia cresciam mais rapidamente do que as bactérias oxidadoras de nitrito, a temperaturas superiores a $15^{\circ} \mathrm{C}$ e com pH entre 7 e 8 . Portanto, um controle rigoroso combinado da temperatura de operação, do tempo de retenção celular e do $\mathrm{pH}$, seriam fundamentais para a produção de nitrito. Em reatores de mistura, com baixos tempos de detenção hidráulica, as bactérias nitratantes seriam seletivamente removidas do reator, proporcionando, portanto, acúmulo de nitrito no meio. A seguir, é mostrado na Figura 2, que representa a relação entre o tempo mínimo de retenção celular (TDH Mínimo) e a temperatura para as bactérias do gênero Nitrossomonas (Oxidadoras de Amônia) e Nitrobacter (Oxidadoras de nitrito):

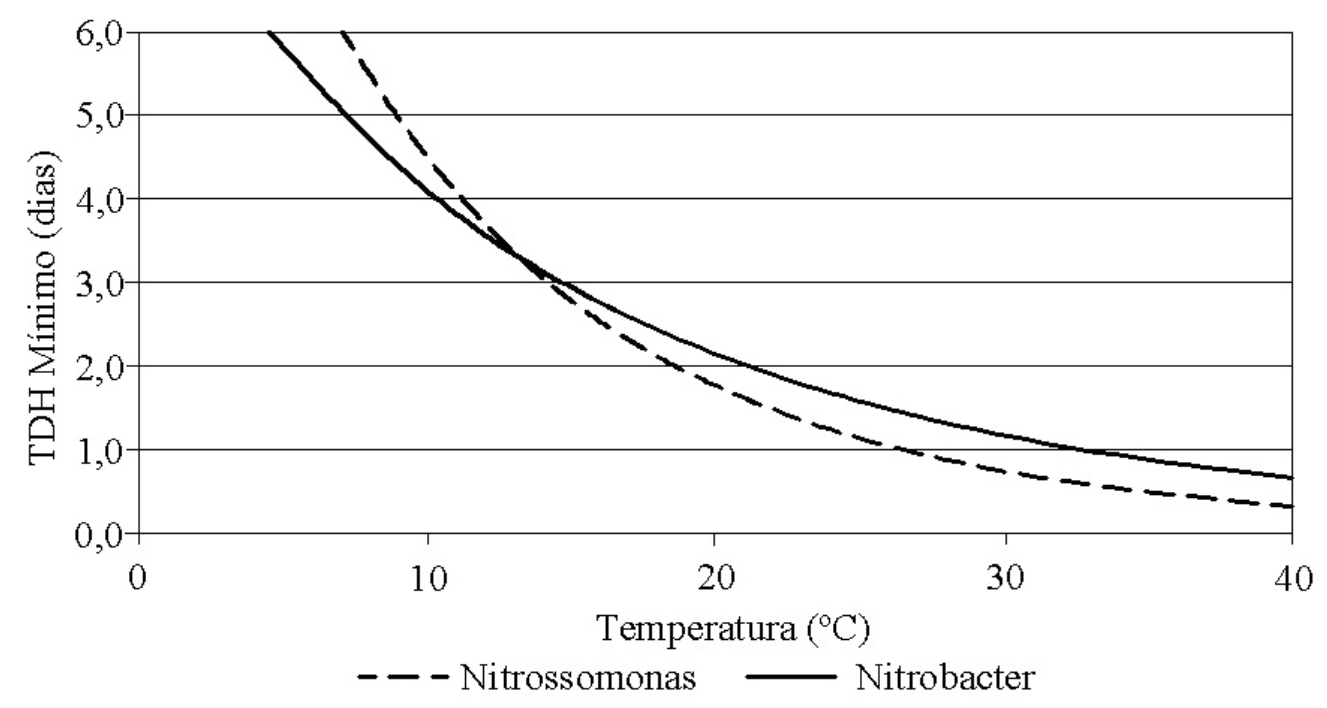

Figura 2: Relação entre a temperatura e o tempo mínimo de retenção celular, para as bactérias nitrificantes do gênero Nitrossomonas e Nitrobacter. Adaptado de Mulder e van Kemper, (1997). 


\subsubsection{Nitrificação Parcial}

As vantagens da oxidação parcial do nitrogênio amoniacal até nitrito foram apresentadas no tópico anterior. No processo SHARON, o acúmulo de nitrito no sistema se deve basicamente ao controle populacional de microrganismos nitritantes e nitratantes, ao tempo de detenção hidráula (em sistemas contínuos de mistura completa, sem imobilização e sem recirculação de biomassa) e pela temperatura, devido a diferentes tempos de geração desses microrganismos.

Pode-se também alcançar o acúmulo de nitrito em sistemas aeróbios sem controle das bactérias nitrificantes: sistemas em batelada, sistemas com biomassa imobilizada ou sistemas com tempo de retenção celular elevados. O acúmulo de nitrito nesses sistemas se dá basicamente pela inibição dos microrganismos oxidadores de nitrito pela amônia livre. Concentrações de 1 a $5 \mathrm{mg}$ de $\mathrm{N}-\mathrm{NH}_{3}$ inibem as nitratantes e não a nitritantes (ABELING e SEYFRIEND, 1992 apud VILLAVERDE et al., 2000). Em determinadas concentrações e pH, alguns compostos orgânicos e metais pesados podem inibir os microrganismos nitratantes. (SUTHERSAN e GANCZARCZYK, 1886; RANDALL e BUTH, 1984). Portanto, o pH, a temperatura e a concentração de nitrogênio amoniacal são os principais parâmetros a serem controlados. Os microrganismos que oxidam amônia à nitrito são menos sensíveis do que os microrganismos que oxidam nitrito à nitrato.

Outros fatores como baixas concentrações de oxigênio no meio (ÇEÇEN e GONENC, 1995), baixas concentrações de hidroxilamina livre $\left(\mathrm{NH}_{2} \mathrm{OH}\right)$ (YANG e ALLEMAN, 1992) e fases alternadas de nitrificação e desnitrificação no mesmo reator (VILLAVERDE e. al., 2000) parecem ter consistente correlação com a baixa atividade nitritante.

\subsubsection{Nitrificação e Desnitrificação Simultânea - SND}

A nitrificação e desnitrificação simultânea (SND - Simultaneous Nitrification and Denitrification) se dá pela oxidação do nitrogênio amoniacal em fase aeróbia e a redução de compostos oxidados de nitrogênio em um mesmo reator sob condições de aeração que favoreçam o desenvolvimento de micronichos em biofilmes condicionados à um gradiente de oxigênio. As bactérias nitrificantes se desenvolvem em áreas com elevadas concentrações de oxigênio, enquanto os microrganismos desnitrificantes se densenvolvem com baixas concentrações de oxigênio dissolvido no interior do biofilme (MUNCH et al., 1996), conforme se vê na Figura 3 : 


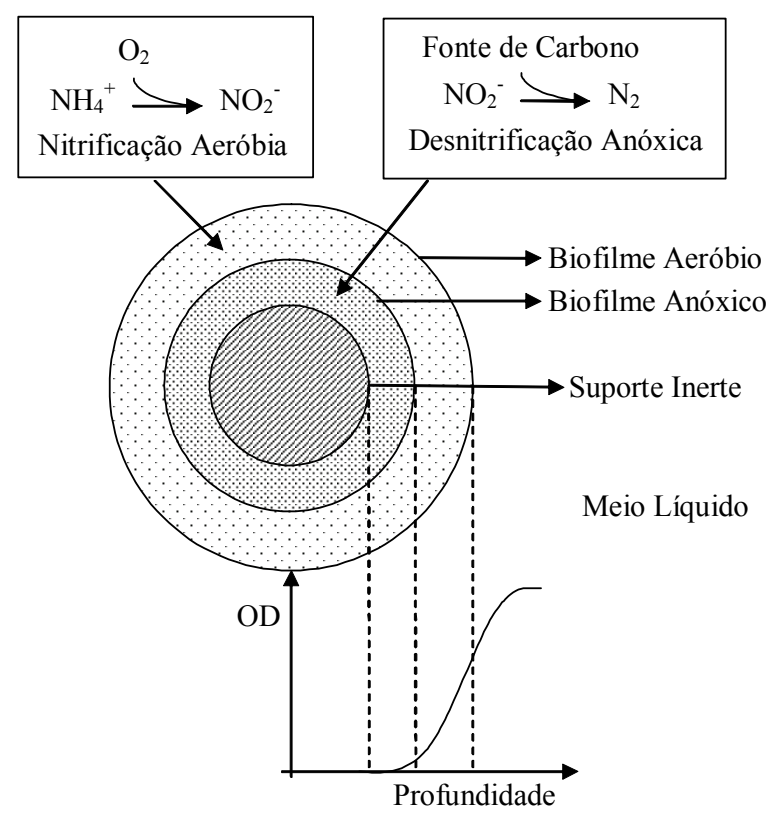

Figura 3: Representação de biofilme em suporte inerte com gradiente de oxigênio dissolvido formando zonas aeradas e anóxicas. Adaptado de "Applications of Cell Immobilization Biotechnology - NEDOVIĆ e WILLAERT (2005)".

Segundo Pochana e Keller (1999) a nitrificação e a desnitrificação simultânea são fenômenos físicos causados pela limitação da difusão do oxigênio no biofilme e segundo esses mesmos autores, para a concentração de $0,5 \mathrm{mg} . l^{-1}$ a velocidade de nitrificação se iguala à velocidade de desnitrificação. Devido à baixas concentrações de oxigênio dissolvido no meio, a nitrificação pode se dar até nitrito (ÇEÇEN e GONENC, 1994). Este fato pode ser interessante na nitrificação e desnitrificação simultânea, pois os requisitos de matéria orgânica para a desnitrificação via nitrito são teoricamente 40\% (MULDER e VAN KEMPER, 1997) menor comparando-se com a desnitrificação de nitratos.

Outros autores relacionam diferentes concentrações de oxigênio dissolvido no meio para alcançar a nitrificação e a desnitrificação simultânea. Em sistemas de biomassa imobilizada há de se fazer ressalvas em relação à essas concentrações de oxigênio limitantes, pois este parâmetro irá depender da estrutura do biofilme, como espessura e forma, e também do grau de aderência do biofilme, além de outros fatores como o tipo de material suporte utilizado.

\subsubsection{ANAMMOX}

Em 1995, Mulder e colaboradores, operando um reator fluidificado com células imobilizadas, que tratava efluente de um reator metanogênico, observaram que grandes 
quantidades de íons amônia eram removidas do sistema, concomitantemente com o consumo de nitrato e elevada produção de gás nitrogênio. Posteriormente, Van de Graaf et al., (1996) e Madigan et al., (1997) observaram que nitrito é aceptor de elétrons preferencial para este processo, chamado ANAMMOX (“ANaerobic AMMonia OXidation”).

Van de Graaf et al., (1996) propuseram uma reação estequimétrica avaliada por meio do balanço de massa, descrita na Equação 6:

$$
\mathrm{NH}_{3}+1,31 \mathrm{NO}_{2}^{-}+0,0425 \mathrm{CO}_{2}+\mathrm{H}^{+} \longrightarrow 1,045 \mathrm{~N}_{2}+0,22 \mathrm{NO}_{3}^{-}+1,87 \mathrm{H}_{2} \mathrm{O}+0,09 \mathrm{OH}^{-}+0,0425 \mathrm{CH}_{2} \mathrm{O} \text { Biomassa }
$$

O principal produto do ANAMMOX é o $\mathrm{N}_{2}$, mas aproximadamente $10 \%$ do nitrogênio alimentado (amônia e nitrito) são convertidos a nitrato $\left(\mathrm{NO}_{3}{ }^{-}\right)$. O processo ANAMMOX é promissor, pois não requer fonte de carbono para remoção de nitrogênio, por se tratar de processo litoautotrófico. O crescimento de biomassa nestes sistemas é muito baixo, portanto é preciso um sistema eficiente de separação de sólidos e um longo período de partida para se obter concentração de biomassa suficiente para manutenção da operação (JETTEN et al., 1997).

\subsubsection{Nitrificação Heterotrófica e Desnitrificação aeróbia}

A nitrificação heterotrófica se mostra interessante, principalmente pelo fato de que estes organismos são também capazes de realizar a desnitrificação aeróbia na presença de matéria orgânica (ROBERTSON et al., 1988; ANDERSSON e LEVINE, 1986; VAN NIEL et al., 1987). O crescimento de todos os microrganismos capazes de realizar a nitrificação heterotrófica é completamente dependente da oxidação de compostos orgânicos (KUENEN e ROBERTSON, 1987). O produto final da nitrificação heterotrófica é geralmente nitrito (CASTIGNETTI e GUNNER, 1980), o qual pode servir de substrato para as bactérias litoautotróficas oxidadoras de nitrito e/ou para as bactérias heterotróficas desnitrificantes, dependendo da condição ambiental imposta.

Um exemplo deste microrganismo é o Paracoccus denitrificans, mais conhecido como Thiosphaera pantotropha, que pode produzir nitrito a partir de uréia, amônia e hidroxilamina e é também capaz de reduzir o nitrito em condições de aerobiose estrita (ROBERTSON e KUENEN, 1988). Essa bactéria é capaz de se desenvolver em ambientes mixotróficos e heterótrofos e também é capaz de oxidar compostos de enxofre para geração de energia 
(GUPTA et al., 1997). A velocidade de nitrificação heterotrófica é menor em relação à nitrificação autótrofa, porém pode se desenvolver em ambientes em que a nitrificação autótrofa não ocorre, como por exemplo, em meios ácidos (ROBERSON e KUENEN, 1988).

Análises mais recentes revelaram novas espécies, tais como Microvirgula aerodenitrificans (PATUREAU et al., 1998) e Thauera mechernichensis (SCHOLTEN et al., 1999), capazes de realizar a desnitrificação aeróbia, mesmo em condições de saturação de oxigênio. Estes microrganismos podem co-respirar oxigênio e óxidos de nitrogênio em condições de aerobiose e produzir $\mathrm{N}_{2}$. São microrganismos heterótrofos e podem crescer utilizando acetato, etanol e glicerol como doador de elétrons (PATUREAU et al., 1998; SCHOLTEN et al., 1999).

\subsubsection{Processo NOx - Desnitrificação por Nitrificantes}

Microrganismos semelhantes às Nitrossomonas podem nitrificar e desnitrificar simultaneamente sob condições de aerobiose estrita, controlando e estimulando a atividade desnitrificante pela adição de concentrações traços de óxidos de nitrogênio $\left(\mathrm{NO} / \mathrm{NO}_{2}\right)$, obtendo como produto principal, nitrogênio molecular (SCHMIDT et al., 2003). Este processo, testado em escala piloto $\left(3,5 \mathrm{~m}^{3}\right)$ sob altas concentrações de nitrogênio amoniacal (2 $\mathrm{kg} \mathrm{N}-\mathrm{NH}_{4}{ }^{+} \cdot \mathrm{m}^{-3}$ ), alcançou uma média de remoção de aproximadamente $67 \%$ do nitrogênio presente com 200 ppm de $\mathrm{NO}_{2}{ }^{-}$(KUAI e VERSTRAETE, 1998).

Segundo Schmidt et al. (2003), os custos para implementação desse sistema em plantas já existentes são baixos (€10.000 a €55.000, dependendo da dimensão da planta) e os custos para o fornecimento de $\mathrm{NO}_{2}$ são de $€ 0,05$ a $€ 0,08$ por kilograma de $\mathrm{N}$-amônia, porém, podem-se reduzir os custos em até $80 \%$ relacionados com a adição de matéria orgânica e $50 \%$ com o fornecimento de oxigênio.

\subsection{PROCESSOS COMBINADOS}

\subsubsection{CANON}

No processo CANON ("Completely Autotrophic Nitrogen removal Over Nitrite"), amônio é parcialmente convertido a nitrito pelas bactérias oxidadoras de amônia, sob condições limitadas de oxigênio e, em seguida, bactérias ANAMMOX convertem o nitrito produzido com parte do amônio remanescente formando nitrogênio gasoso. (SLIEKERS et al., 2002; JETTEN et al., 2003). 
Neste processo, a oxidação aeróbia de amônia e a oxidação anaeróbia de amônia (ANAMMOX) ocorrem no mesmo reator. Condições de limitação de oxigênio são impostas para que estes dois processos oxidativos de amônia aconteçam ao mesmo tempo. A oxidação de nitrito $\left(\mathrm{NO}_{2}{ }^{-}\right)$à nitrato $\left(\mathrm{NO}_{3}{ }^{-}\right)$é prevenida pela operação à elevadas concentrações de $\mathrm{NH}_{3}$ no sistema (NIELSEN et al., 2005).

\subsubsection{OLAND}

No processo OLAND (“Oxygen Limited Autotrophic Nitrification Denitrification”), o oxigênio é fornecido em quantidade limitada para que a nitrificação proceda apenas até nitrito. Devido à escassez de aceptores de elétrons, o nitrito formado é consumido para oxidar o restante do amônio (VERSTRAETE e PHILIPS, 1998).

A principal diferença entre o processo CANON e o OLAND é que este faz uso da atividade desnitrificante pelas bactérias aeróbias nitrificantes e aquele incorpora $o$ ANAMMOX. No processo OLAND, as bactérias do gênero Nitrossomonas, oxidadoras de amônia, obtêm energia a partir da combinação da nitrificação e da desnitrificação autotrófica (VERSTRAETE e PHILIPS, 1998), como se pode observar nas Equações 7 e 8, :

$$
\begin{array}{lc}
0,5 \mathrm{NH}_{3}+0,75 \mathrm{O}_{2} \longrightarrow 0,5 \mathrm{NO}_{2}{ }^{-}+0,5 \mathrm{H}_{2} \mathrm{O} & \Delta \mathrm{G}^{\mathrm{o}}=-384 \mathrm{~kJ} \\
0,5 \mathrm{NH}_{3}+0,5 \mathrm{NO}_{2}{ }^{-}+\mathrm{H}^{+} \longrightarrow 0,5 \mathrm{~N}_{2}+\mathrm{H}_{2} \mathrm{O} & \Delta \mathrm{G}^{\mathrm{o}}=-360 \mathrm{~kJ}
\end{array}
$$

Comparado-se ao processo de nitrificação e desnitrificação convencional, verifica-se a economia de $62,5 \%$ de oxigênio e não há necessidade de adição de fonte de carbono, pelo fato das bactérias responsáveis por esse processo utilizarem o próprio íon amônia como agente redutor. A oxidação direta de amônio a nitrogênio gasoso pode ser alcançada em única fase. Este processo não requer condições anóxicas, mas pode ocorrer em condições microaeróbias (VERSTRAETE e PHILIPS, 1998).

\subsubsection{DEAMOX}

O processo DEAMOX (DEnitrifying AMmonium OXidation) se baseia na desnitrificação autotrófica e utiliza o sulfeto como doador de elétrons para produção de nitrito a partir da redução do nitrato em processo anaeróbio (KALYUZHNYI et al., 2006). O nitrito 
formado juntamente com o nitrogênio amoniacal dá ensejo ao processo ANAMMOX, conforme as Equações 9 e 10 :

DEAMOX: $\quad 4 \mathrm{NO}_{3}^{-}+\mathrm{HS}^{-} \rightarrow 4 \mathrm{NO}_{2}^{-}+\mathrm{SO}_{4}^{-2} \quad \Delta \mathrm{G}=-453 \mathrm{~kJ}$

ANAMMOX: $\quad \mathrm{NH}_{3}+\mathrm{NO}_{2}^{-}+\mathrm{H}^{+} \rightarrow \mathrm{N}_{2}+2 \mathrm{H}_{2} \mathrm{O} \quad \Delta \mathrm{G}=-360 \mathrm{~kJ}$

Como se pode observar na Figura 4, neste processo é necessário à produção de nitrato em uma unidade separada. No reator anaeróbio anterior, a matéria orgânica prontamente degradável é consumida e é produzido sulfeto a partir da redução de sulfato. No reator DEAMOX, combina-se parte do efluente do reator nitrificante e parte do reator anaeróbio, para a redução de nitrato a nitrito utilizando sulfeto como doador de elétrons (processo DEAMOX) e em seguida à utilização do nitrito e nitrogênio amoniacal para a ocorrência do processo ANAMMOX.

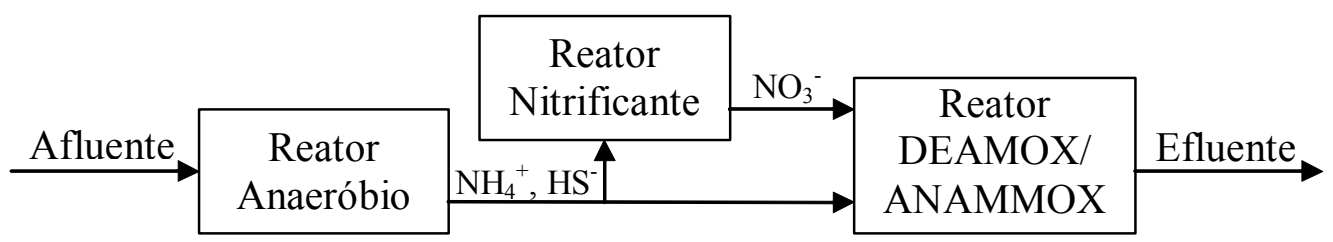

Figura 4: Fluxograma do conceito do processo DEAMOX.

Nota-se que tanto o processo DEAMOX quanto o processo ANAMMOX são processos autotróficos, portanto é muito importante que o reator anaeróbio tenha uma boa eficiência de remoção de matéria orgânica para não afetar os processos autotróficos à jusante. A água residuária deve necessariamente conter elevadas concentrações de sulfato para a produção de sulfeto suficiente para reduzir o nitrato à nitrito.

\subsection{DESNITRIFICAÇÃO AUTOTRÓFICA UTILIZANDO COMPOSTOS DE ENXOFRE}

A desnitrificação utilizando compostos de enxofre se baseia na desnitrificação autotrófica pelas bactérias oxidadoras de enxofre, tais como Thiobacillus denitrificans e Thiomicrospira denitrificans. Essas bactérias são quimiolitotróficas e, em ambientes anóxicos, oxidam compostos reduzidos de enxofre, como sulfeto, sulfito, tiossulfato e enxofre 
elementar, à sulfato. Também são capazes de utilizar hidrogênio para desnitrificar (AHN et al., 2006; WANG et al., 2005). A desnitrificação utilizando compostos reduzidos de enxofre como fonte de energia foi observada com baixas relações C/N (DRISCOLL et al., 1978; TROUVE et al., 1998). Porém, Gommers et al. (1988) relataram evidências da ocorrência deste processo litoautotrófico quando matéria orgânica é presente.

Os principais produtos deste processo quimiolitotrófico são nitrogênio gasoso, sulfato e em alguns casos, enxofre elementar. Além do nitrato, Thiobacillus denitrifican também podem utilizar $\mathrm{NO}$ e $\mathrm{N}_{2} \mathrm{O}$ como aceptores de elétrons (WANG et al., 2005).

\subsubsection{SURAMOX}

Fdz-Polanco et al. (2001) operaram um reator anaeróbio de leito fluidificado e carvão ativado granular tratando vinhaça oriunda de destilaria de etanol e verificaram que uma porcentagem importante $(50 \%)$ do nitrogênio entrando no reator como NTK foi removida da fase líquida, aparecendo como $\mathrm{N}_{2}$ na fase gasosa. Simultaneamente, apenas $20 \%$ do sulfato presente no inicio no efluente apareceu como sulfeto no efluente ou como sulfeto de hidrogênio no gás, indicando que $80 \%$ do enxofre foi removido. Este novo processo foi chamado de SURAMOX (SUlfate Reduction and AMmonia Oxidation), onde a energia livre de Gibbs, calculado por meio de dados termodinâmicos, da reação teórica, é negativa, mostrando a viabilidade de ocorrência desta reação por microrganismos (VILLAVERDE, 2004). A reação teórica é mostrada a seguir:

$$
\mathrm{SO}_{4}^{2-}+2 \mathrm{NH}_{3}+2 \mathrm{H}^{+} \rightarrow \mathrm{S}^{0}+\mathrm{N}_{2}+4 \mathrm{H}_{2} \mathrm{O} \quad \Delta \mathrm{G}^{\mathrm{o}}=-45 \mathrm{~kJ}
$$

Apesar da reação proposta pelos autores (Equação 11), ainda não há muita informação sobre este processo. Até o presente momento não se tem notícia da reprodutividade do processo SURAMMOX.

Em sistemas de tratamento biológico de águas residuárias para remoção de nitrogênio, vários processos ocorrem simultaneamente. A imposição de uma condição ao reator pode favorecer um processo ao outro, no entanto, é difícil distinguir os processos com contribuições minoritárias. Ferramentas de análise microbiológicas mais acuradas como FISH ("Fluorescent in situ hybridization"), sequenciamento genético dos microorganismos e modelos matemáticos, entre outras ferramentas, podem indicar tais processos minoritários. 


\section{Capítulo 3}

\section{Material e Métodos}

O sistema experimental utilizado nesta pesquisa foi construído e operado nas dependências do Laboratório de Processos Biológicos - LPB do Departamento de Hidráulica e Saneamento - SHS da Escola de Engenharia de São Carlos - EESC da Universidade de São Paulo - USP.

\subsection{VISÃO GERAL DO PROCEDIMENTO EXPERIMENTAL}

Basicamente, os experimentos foram divididos em 3 etapas, conforme esquematizado na Figura 5 e descritos resumidamente a seguir. Além das etapas principais, foram realizados ensaios complementares e exames microbiológicos de microscopia óptica, de microscopia eletrônica de varredura e avaliação de comunidades microbianas por meio de algumas técnicas de biologia molecular. A descrição detalhada das etapas está no item 3.5 Procedimento experimental.

ETAPA 1 - Esta foi a etapa inicial utilizada para observar o comportamento do reator operado em batelada seqüencial com biomassa suspensa nas fases de aeração e não aeração. Nesta etapa, optou-se inicialmente por estratégia de operação com 4 fases alternadas aeróbias/anóxicas, com ciclo total de 24 horas. Na fase anóxica, não foi adicionado qualquer tipo de fonte externa de carbono. Portanto, essa etapa teve por objetivo a verificação da ocorrência da desnitrificação endógena. $\mathrm{Na}$ fase aeróbia, foram realizados testes para verificar a melhor vazão de ar aplicada no sistema que favorecia a nitrificação.

ETAPA 2 - Com a finalização da Etapa 1 anterior, constatou-se a possibilidade de se omitir algumas fases. Pretendeu-se, portanto, a otimização do sistema, com a redução do número de fases e optou-se por utilizar apenas duas: a primeira fase de aeração e a segunda fase anóxica. Nesta nova etapa, cada fase teve duração de 6 horas, perfazendo um ciclo de 12 horas. Na fase anóxica, com intuito de otimizar a desnitrificação, adicionou-se efluente originário de reator 
sulfetogênio e de reator metanogênico. Como a quantidade de biomassa nesta etapa foi diminuída em aproximadamente $40 \%$ em relação à etapa anterior, necessitou-se nova verificação para ajuste da melhor vazão de ar para nitrificação.

ETAPA 3 - Esta etapa foi semelhante à Etapa 2 anterior. No entanto, utilizou-se um reator com biomassa imobilizada. A estratégia de aeração e não aeração foi a mesma, assim como a adição de afluente na fase desnitrificante. A vazão de ar utilizada desta etapa foi a melhor vazão encontrada na etapa anterior. Para a escolha do melhor material suporte, inoculou-se biomassa em reator tipo célula com diferentes suportes inertes. Foram utilizados ensaios com microsensores de oxigênio dissolvido para determinação das espessuras dos biofilmes. Escolheu-se então, o meio suporte que favorecesse o desenvolvimento, não excessivo, de filme aeróbio e anóxico para aplicação no reator nitrificante/desnitrificante.

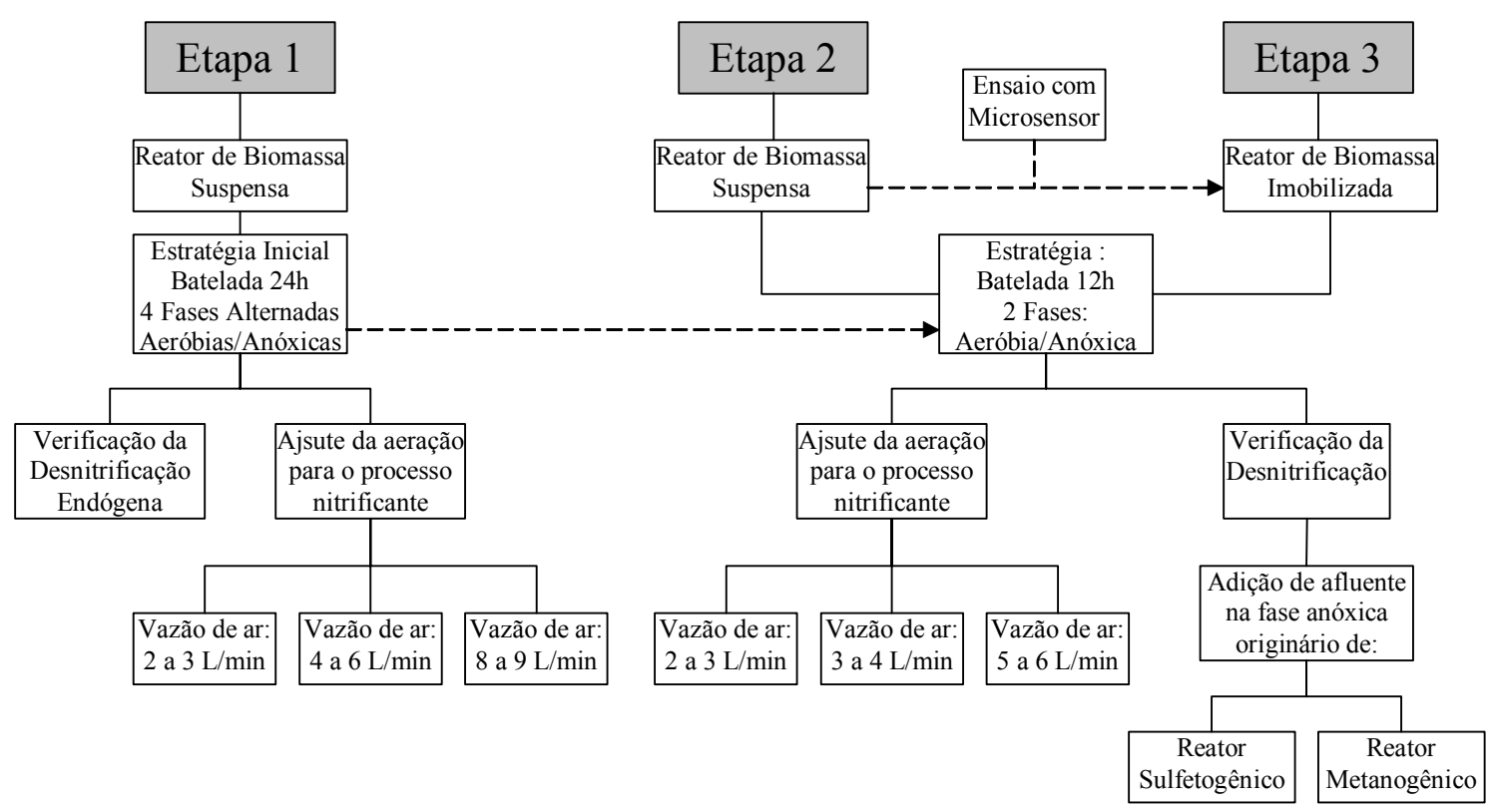

Figura 5: Fluxograma do procedimento experimental.

\subsection{DESCRIÇÃO DOS EQUIPAMENTOS}

\subsubsection{Reator Batelada Seqüencial com Biomassa Suspensa}

Foi utilizado um reator operado em bateladas seqüenciais e contendo biomassa suspensa, o qual havia sido usado anteriormente por Iamamoto (2006). O reator foi confeccionado em acrílico, com volume total de 6,5 litros. A agitação era promovida por 18 
impelidores do tipo pás planas, controlada por dispositivo eletromecânico. $\mathrm{O}$ ar era injetado por meio de pedras porosas, dispostas no fundo do reator, de maneira a difundir o gás no meio líquido. O reator possuía paredes laterais duplas, para permitir a circulação de água proveniente de banho ultra-termostatizado entre elas, de maneira a manter a temperatura de operação controlada a $30 \pm 1{ }^{\circ} \mathrm{C}$, confome mostrado na Figura 6. As dimensões do reator e suas tomadas laterais e de fundo podem ser vistas na Figura 7.

A alimentação do reator era feita utilizando-se uma bomba dosadora (Prominent ${ }^{\circledR}$ Concept), sendo que o líquido era previamente aquecido pela passagem por uma serpentina imersa em banho-maria. O descarte do líquido tratado era realizado por bomba dosadora (Prominet ${ }^{\circledR}$ Concept) e a canalização de descarte era provida de sistema anti-sifão. A vazão de ar era regulada por um medidor com escala de 1 a 10 litros de ar por minuto.

O sistema era controlado via computador por meio de placa decodificadora de sinais interligada à duas válvulas solenóides, bombas alimentadoras e de descarte, e agitador mecânico. Para as diferentes fases de operação, o agitador mecânico, os períodos de aeração e não aeração, bem como a operação das bombas de enchimento e descarte eram controlados por este sistema automatizado.

Os valores de $\mathrm{pH}$ e de potencial de óxido-redução (REDOX) eram obtidos por eletrodos específicos acoplados ao medidor multi-sondas ORION $^{\circledR}$ modelo 920A Plus. O oxigênio dissolvido era quantificado por meio do medidor de oxigênio dissolvido ORION ${ }^{\circledR}$ modelo 810A.

As leituras de $\mathrm{pH}, \mathrm{REDOX}$ e OD eram enviadas pelos medidores ORION $^{\circledR}$ via cabo serial ligadas às portas RS232C de um micro-computador a cada 10 segundos. $\mathrm{O}$ software para a aquisição, desenvolvido pela empresa T\&S foi modificado para alternar os canais de leituras do $\mathrm{pH}$ e REDOX do aparelho ORION ${ }^{\circledR}$ 920A Plus e enviar os sinais digitais para o computador em períodos de 5 segundos alternadamente. O software supracitado foi modificado para registrar diferentes entradas digitais simultaneamente e desenvolveu-se também um sistema de controle baseado em faixas de $\mathrm{pH}$, REDOX e OD que automaticamente ligava/desligava canais, de maneira a manter os valores dos parâmetros dentro das faixas desejadas. Este sistema automático para controle de variáveis $(\mathrm{pH}, \mathrm{REDOX}$ e OD) não foi utilizado, porém, poderá ser utilizado posteriormente para controle de parâmetros operacionais em sistemas de tratamento. 

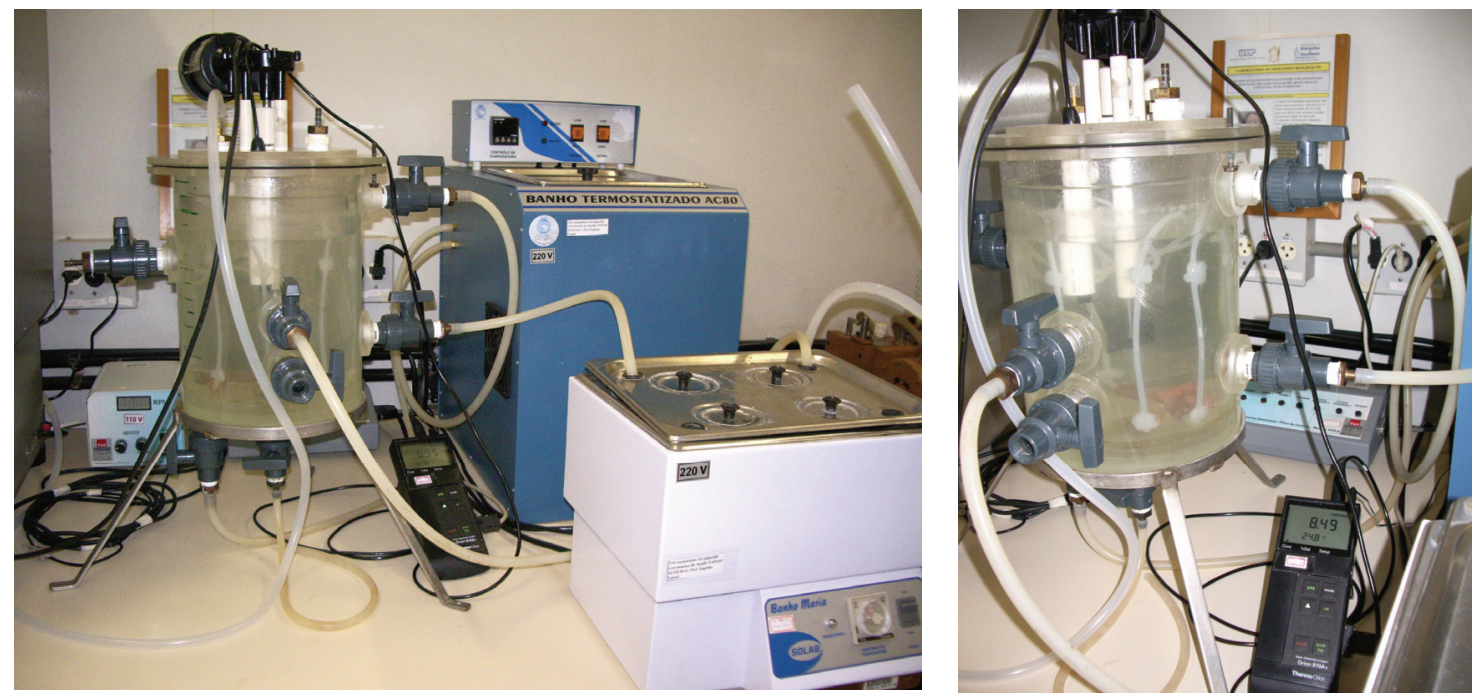

Figura 6: Instalação experimental utilizada para as Etapas 1 e 2.

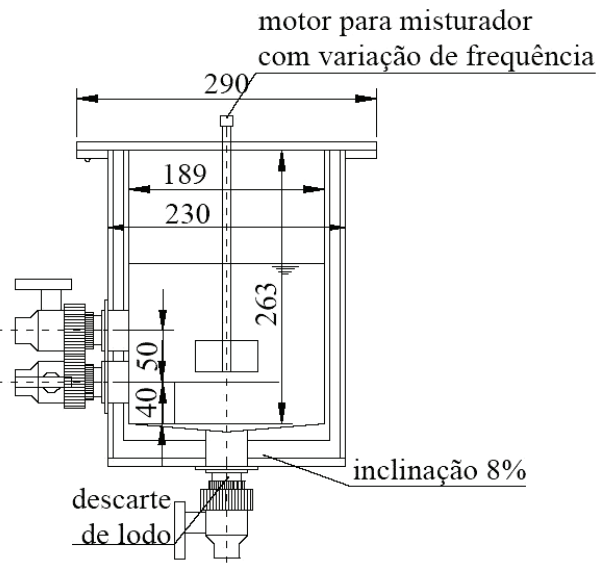

Corte A-A

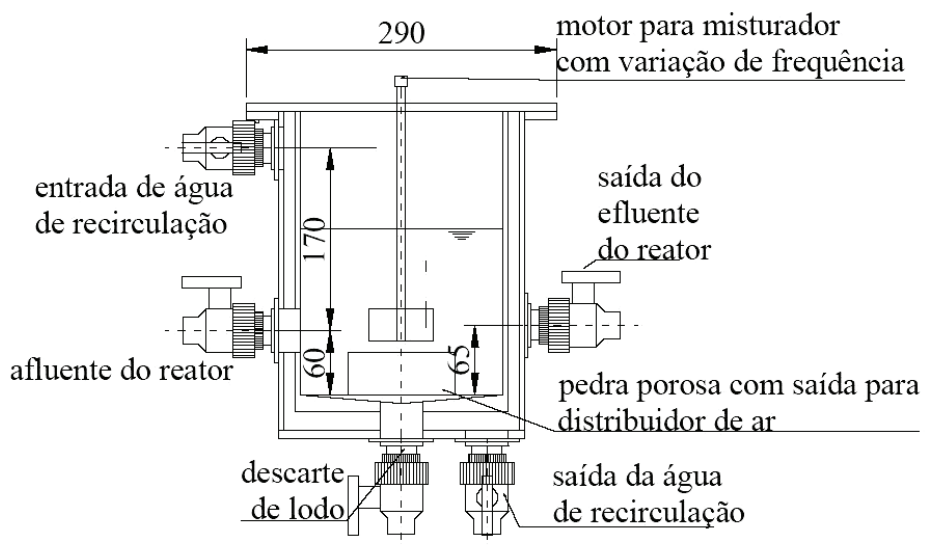

Corte B-B

Figura 7: Detalhes do reator utilizado para as Etapas 1 e 2 (IAMAMOTO, 2006).

\subsubsection{Reator Batelada Sequencial com Biomassa Imobilizada}

O reator utilizado com biomassa imobilizada e operado em bateladas seqüenciais foi confeccionado em acrílico, com volume total de 15 litros e volume útil de 7 litros. Tal unidade tinha formato cilíndrico com $15 \mathrm{~cm}$ de diâmetro e $90 \mathrm{~cm}$ de altura, conforme mostrado na Figura 8. O reator foi preenchido com pedaços carvão mineral, sem nenhum préprocessamennto, com diâmetro médio de $3,5 \mathrm{~cm}$. A porosidade do leito inicial foi de aproximadamente $50 \%$.

O reator era provido de sistema de recirculação, no qual o líquido era succionado por bomba dosadora (Prominent ${ }^{\circledR}$ Concept), na tomada de coleta 5 (Figura 8) e re-injetado pela tomada de coleta de fundo, com uma vazão de $23 \mathrm{~L} . \mathrm{h}^{-1}$. No fundo do reator, havia uma placa 
de alumínio perfurada para que o líquido recirculado fosse distribuído de forma uniforme pela seção transversal do reator.

No fundo do reator também havia um tubo de PVC de 1/4", com furos de $1 \mathrm{~mm}$ para a melhor distribuição de ar no meio líquido. Este tubo de PVC era ligado à rede de ar comprimido. O sistema permanecia em câmara climatizada, que mantinha a temperatura em $30 \pm 1{ }^{\circ} \mathrm{C}$. A alimentação do reator, o descarte e o acionamento da aeração eram manuais, sendo que essas operações obedeciam aos tempos pré-determinados do ciclo.

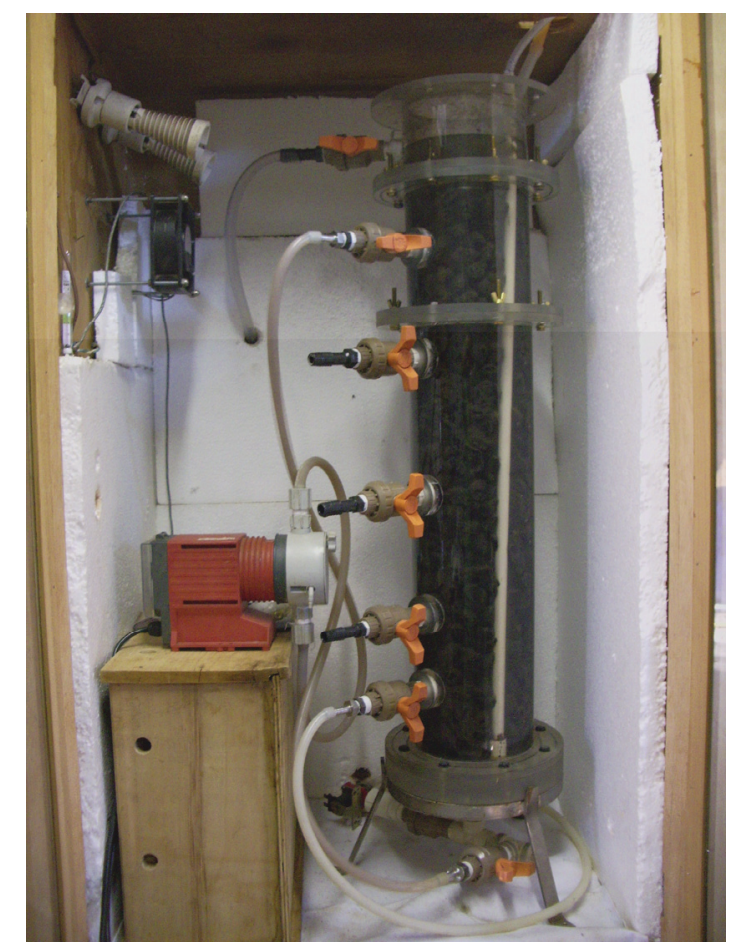

6

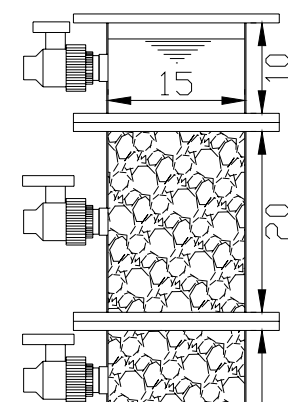

4

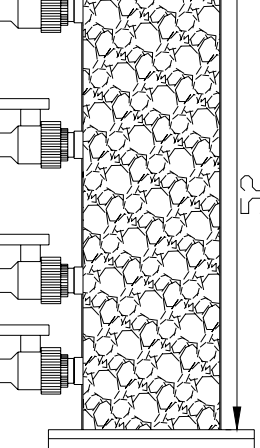

(1)

Figura 8: Instalação experimental e detalhes do reator utilizado na Etapas 3.

\subsection{LODO DE INÓCULO}

O reator contendo biomassa suspensa foi inoculado com 2,5 litros de lodo granular, proveniente de reator UASB da estação de tratamento de águas residuárias de abatedouro de aves da empresa Dacar Industrial S.A., localizada na cidade de Tietê - SP - Brasil, e com 0,5 litro de lodo de reator nitrificante/desnitrificante, para remoção de elevadas concentrações de nitrogênio amoniacal do experimento em bancada, anteriormente utilizado por Iamamoto (2005). O lodo granular foi inserido no sistema sem nenhum tratamento ou processamento prévio.

O sistema de biomassa imobilizada foi inoculado com 0,5 litro de lodo do sistema de biomassa suspensa utilizado nesta pesquisa, já adaptado às condições nitrificantes e 
desnitrificantes e 2 litros de lodo granular proveniente de reator UASB da empresa Dacar Industrial S.A. in natura.

\section{4. ÁGUAS RESIDUÁRIAS}

Parte da pesquisa foi desenvolvida com efluente proveniente de reator piloto do tipo ASBBR (Anaerobic Sequencing Batch Biofilm Reactor) para redução biológica de sulfato via processo anaeróbio (reator sulfetogênico), aplicado ao tratamento de águas residuárias contendo elevadas concentrações de sulfato, da DISSOLTEX Indústria Química Ltda (São Carlos-SP). Outra parte da pesquisa foi desenvolvida com efluente de um reator metanogênico que tratava o efluente do reator sulfetogênico, ambos operados pelo pós-doutorando Dr. Arnaldo Sarti na Escola de Engenharia de São Carlos no Laboratório de Processos Biológicos.

A empresa DISSOLTEX tem como atividade principal a produção de tintas, vernizes, solventes orgânicos, thinners, ceras e nitroceluloses. Além dessas atividades, a empresa fabrica óleos sulfonados para engraxe de couros, que se baseia na sulfonação de óleos vegetais (milho, soja e algodão). Este processo é o principal contribuinte dos resíduos líquidos da empresa, devido à separação do óleo sulfonado proveniente do nos reatores químicos utilizados no processo de sulfonação da indústria (Informação Pessoal) ${ }^{1}$, conforme esquema simplificado de produção, indicada na Figura 9 .

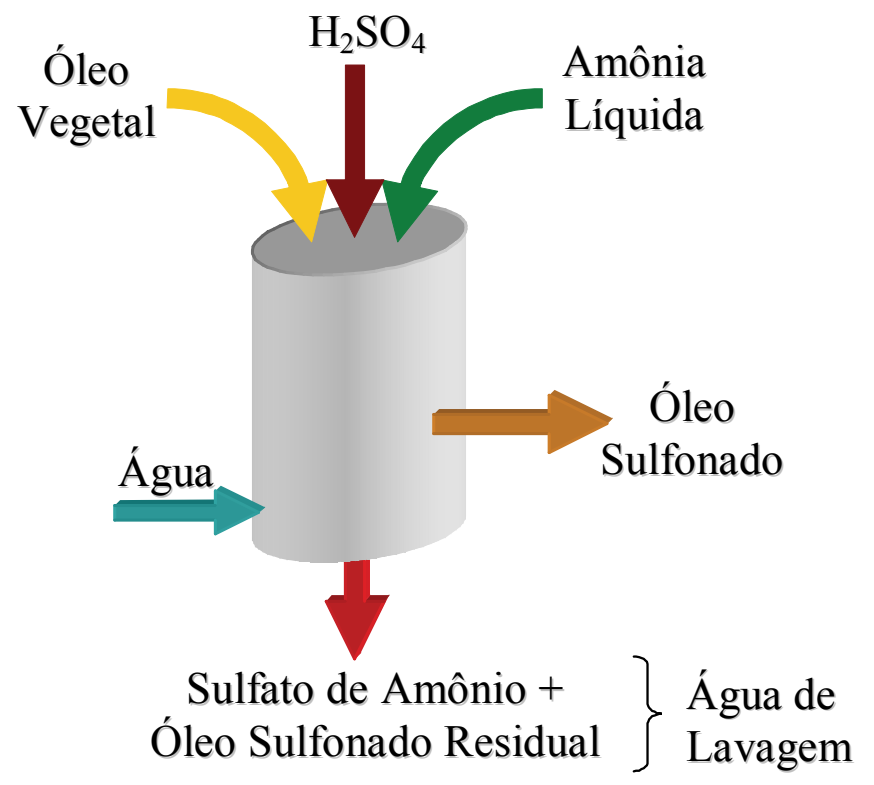

Figura 9: Esquema simplificado da produção de óleo sulfonado.

\footnotetext{
${ }^{1}$ Informação fornecida pelo Dr. Arnaldo Sarti em São Carlos - SP em 2006.
} 
O efluente da DISSOLTEX (água de lavagem), com alta concentração de sulfato (valor médio de $287 \mathrm{gSO}_{4}{ }^{2-} \cdot l^{-1}$ ), era diluído com esgoto sanitário para para completar a capacidade de tratamento do ASBBR, mostrado na Figura 10, de $0,6 \mathrm{~m}^{3}$ de volume líquido composto por leito fixo de "pedaços" irregulares de carvão mineral (diâmetro entre 40 a 80 $\mathrm{mm})$.

O tratamento no reator sulfetogênico (piloto) consistiu, principalmente, na redução dissimilativa do sulfato presente na água de lavagem, pela atividade das bactérias redutoras de sulfato (BRS). $\mathrm{O}$ sulfato $\left(\mathrm{SO}_{4}{ }^{2-}\right)$ é utilizado como aceptor final de elétrons durante o metabolismo respiratório, que produz sulfeto de hidrogênio $\left(\mathrm{H}_{2} \mathrm{~S}\right)$ como um dos produtos finais (SCHAUDER e KRÖGER, 1993). Para adequação do processo de remoção de sulfato, foi adicionado como fonte exógena de matéria orgânica o etanol, para que a redução dissimilativa se processasse adequadamente.

A oxidação de compostos orgânicos pode ser incompleta, levando principalmente à formação de acetato como produto final. Portanto, uma elevada concentração de acetato foi obtida no reator sulfetogênico. Na Tabela 1 , são apresentadas as principais características médias do efluente do reator sulfetogênico utilizado neste trabalho e na Figura 10 é mostrada a foto do reator sulfetogênico, operado pelo pós-doutorando Dr. Arnaldo Sarti.

Tabela 1: Principais compostos e concentrações médias do efluente do reator sulfetogênico e metanogênico².

\begin{tabular}{lccc}
\hline \multirow{2}{*}{ Composto } & \multirow{2}{*}{ Unidade } & \multicolumn{2}{c}{ Reator } \\
\cline { 3 - 4 } & & Sulfetogênico & Metanogênico \\
\hline Sulfato & $\operatorname{mgSO}_{4}^{-2} \cdot l^{-1}$ & $9-335$ & $22-232$ \\
Sulfeto & $\mathrm{mgS}^{-2} \cdot l^{-1}$ & $0,3-202$ & $0,3-130$ \\
Sulfito & $\operatorname{mgSO}_{3}^{-2} \cdot l^{-1}$ & $278-541$ & $2-334$ \\
Nitrogênio Amoniacal & $\operatorname{mgNH}_{4}^{+} \cdot l^{-1}$ & $112-392$ & $165-299$ \\
Ácido Acético & $\mathrm{mgHac}^{-1}$ & $22-625$ & $22-623$ \\
Alcaliniade à Bicarbonato & $\mathrm{mgCaCO}_{3} \cdot l^{-1}$ & $404-1040$ & $1213-1550$ \\
pH & - & $5,3-6,9$ & $7,2-7,9$ \\
\hline
\end{tabular}

\footnotetext{
${ }^{2}$ Nem sempre os efluentes foram utilizados logo após a saída do reator. Em muitos casos, eles foram armazenados e consequentemente as características originais da água residuária foram alteradas não intensionalmente, principalmente com relação às concentrações de compostos de enxofre (devido à oxidação natural do sulfeto).
} 


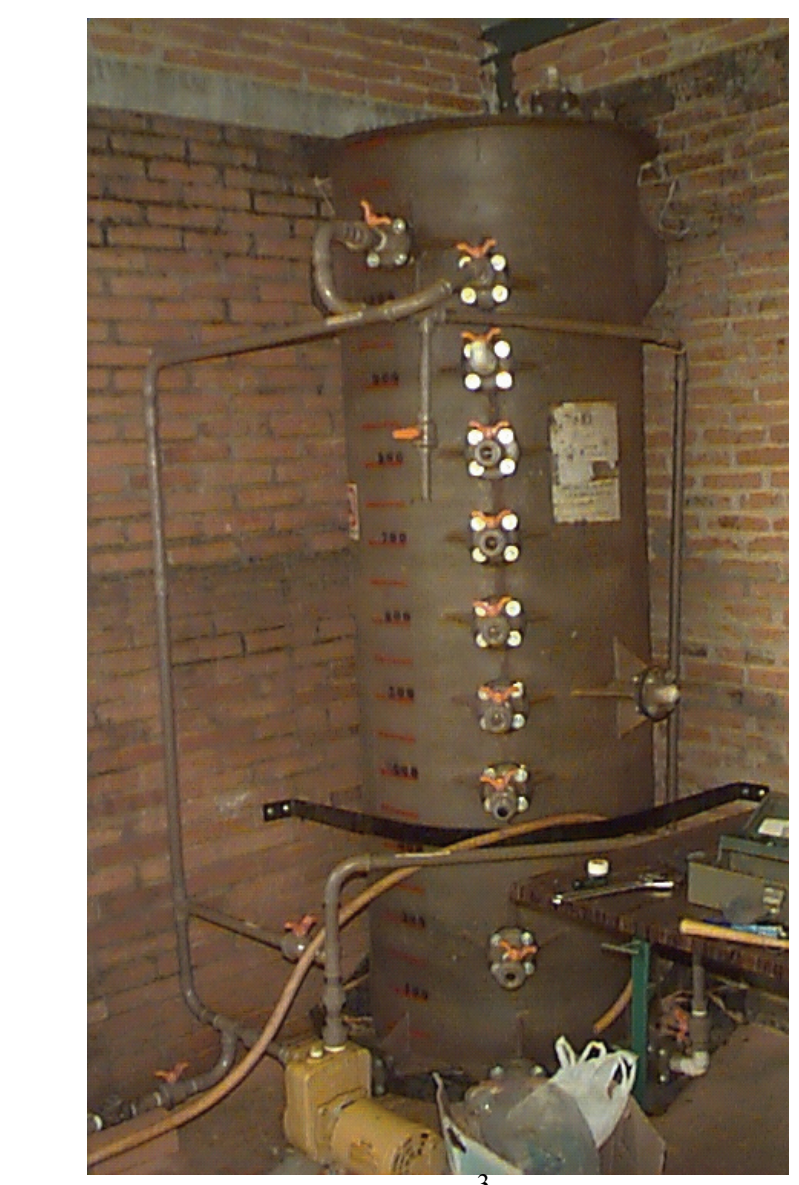

Figura 10: Reator sulfetogênico ${ }^{3}$.

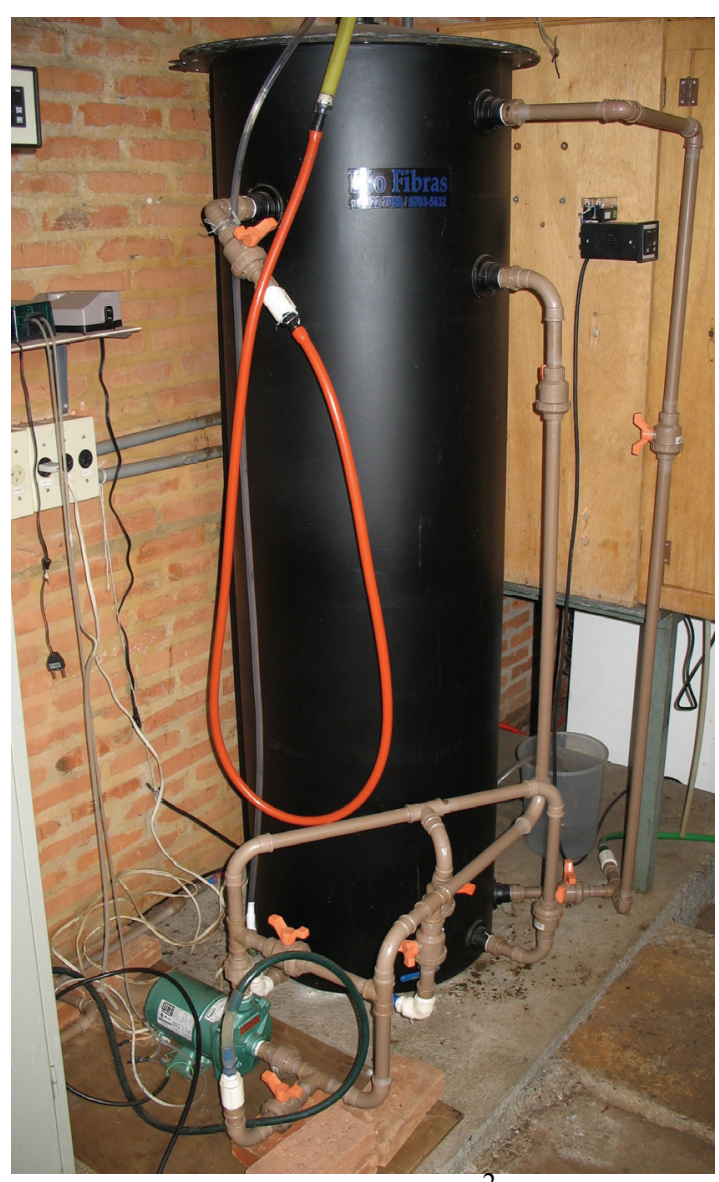

Figura 11: Reator metanogênico ${ }^{2}$

O reator ASBBR metanogênico piloto (volume útil de 430 litros), mostrado na Figura 11 , era preenchido com suporte de carvão mineral, com porosidade de leito $(\varepsilon)$ próxima de $50 \%$, e tinha como objetivo adequar o efluente do reator sulfetogênico com relação às concentrações de matéria orgânica (principalmente ácido acético), conforme legislação vigente. Na Tabela 2 está mostrado as características principais dos reatores sulfetogênico e metanogênico.

Tabela 2: Principais características dos reatores sulfetogênico e metanogênico.

\begin{tabular}{lcc}
\hline \multirow{2}{*}{ Características } & \multicolumn{2}{c}{ Reator } \\
\cline { 2 - 3 } & Sulfetogênico & Metanogênico \\
\hline Volume Total $\left(\mathrm{m}^{3}\right)$ & 1,2 & 0,43 \\
Volume Útil $\left(\mathrm{m}^{3}\right)$ & 0,6 & 0,23 \\
L/D & 3,0 & 3,2 \\
Vazão de Recirculação $\left(\mathrm{m}^{3} \cdot \mathrm{h}^{-1}\right)$ & $3,3-5,6$ & 0,6 a 1,8 \\
Material Suporte & Carvão Mineral & Carvão Mineral \\
\hline
\end{tabular}

${ }^{3}$ Foto cedida pelo Dr. Arnaldo Sarti. 
Não se observou nenhuma transformação/remoção substancial nas concentrações de nitrogênio amoniacal, tanto no reator sulfetogênico quanto no reator metanogênico posterior. $\mathrm{Na}$ Tabela 1, estão apresentados dados médios da composição do efluente do reator metanogênico.

\subsection{PROCEDIMENTO EXPERIMENTAL - DESCRIÇÃO DA OPERAÇÃO}

\subsubsection{ETAPA 1}

Na Etapa 1, utilizou-se estratégia inicial de 4 fases alternadas - aeróbias/anóxicas - a fim de verificar o comportamento dos microrganismos às condições alternadas de aeração e não aeração em reator com biomassa suspensa. Foi proposto, inicialmente, um ciclo de 24 horas para posterior otimização. O reator foi alimentado com 4,5 litros de afluente.

O ciclo era composto por 15 minutos ( 0,25 horas) de enchimento do reator, 5 horas e 45 minutos de aeração (5,75 horas), 6 horas de período anóxico com o impelidor mecânico à $50 \mathrm{rpm}, 6$ horas de aeração, 5 horas e 30 minutos (5,5 horas) de período anóxico com impelidor mecânico a $50 \mathrm{rpm}$ ligado até a terceira hora do início da segunda fase anóxica, finalizando com o descarte de efluente com duração de 30 minutos (0,5 horas). As fases do ciclo podem ser facilmente visualizadas na Figura 12 :

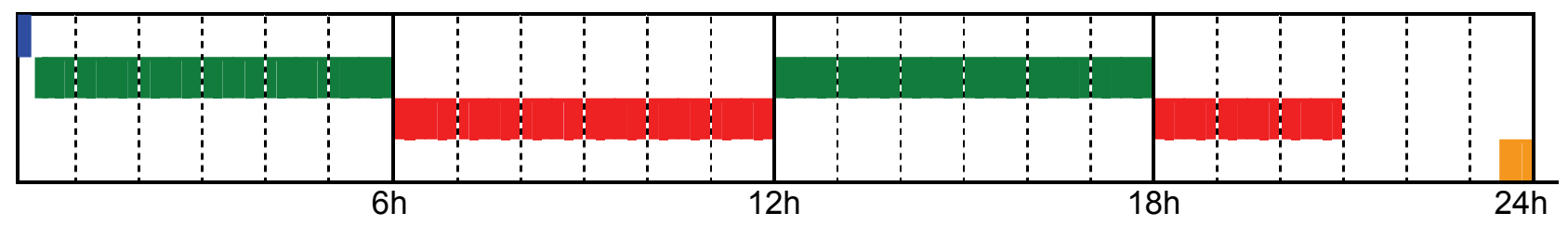

Figura 12: Representação gráfica do ciclo da Etapa 1: Alimentação; Aeração; Agitação; Descarte.

Nas fases aeróbias, variou-se a vazão de ar injetada no sistema a fim de verificar a melhor condição para a ocorrência do processo nitrificante. Paralelamente, pôde-se verificar a influência da insuficiência de aeração sob os processos nitrificantes e desnitrificantes. Foram utilizadas três faixas de vazão de ar diferentes: de 2 a 3 , de 4 a 6 e de 8 a 9 L.min ${ }^{-1}$. O afluente era alcalinizado com bicarbonato de sódio $\left(\mathrm{NaHCO}_{3}\right)$, de forma que a concentração fosse aproximadamente $1000 \operatorname{mgHCO}_{3}^{-} \cdot l^{-1}$, para que a nitrificação não sofresse limitação por alcalinidade. 
Nas fases anóxicas, o agitador mecânico era acionado a baixa velocidade (50 rpm), apenas para manter o sistema homogeneizado, sem provocar grandes perturbações hidrodinâmicas, nem incorporação de ar. Nesta mesma fase, não era adicionada nenhuma fonte de carbono. Pretendeu-se, com isso, a verificação da ocorrência da desnitrificação endógena. Nesta etapa manteve-se uma alta concentração de biomassa no sistema (aproximadamente 8,1 gSVT. $l^{-1}$ ).

\subsubsection{ETAPA 2}

Com a finalização da Etapa 1, constatou-se a possibilidade de se omitir algumas fases. Com o intuito de otimizar o sistema, optou-se pela redução do número de fases. Foram utilizadas, portanto, duas fases: a primeira fase aerada e a segunda fase anóxica. Cada fase nesta nova etapa teve duração de aproximadamente 6 horas, perfazendo um ciclo de 12 horas, metade do ciclo utilizado na etapa anterior. O reator foi alimentado com 4,5 litro de afluente.

O ciclo era composto por 15 minutos (0,25 horas) de enchimento ou alimentação do reator, 5 horas e 45 minutos de aeração (5,75 horas), 5 horas e 30 minutos (5,5 horas) de período anóxico com impelidor mecânico à $50 \mathrm{rpm}$, ligado até a terceira hora do início da fase anóxica, finalizando com o descarte de efluente com duração de 30 minutos (0,5 horas), totalizando um ciclo de 12 horas. A Figura 13 representa as fases do ciclo:

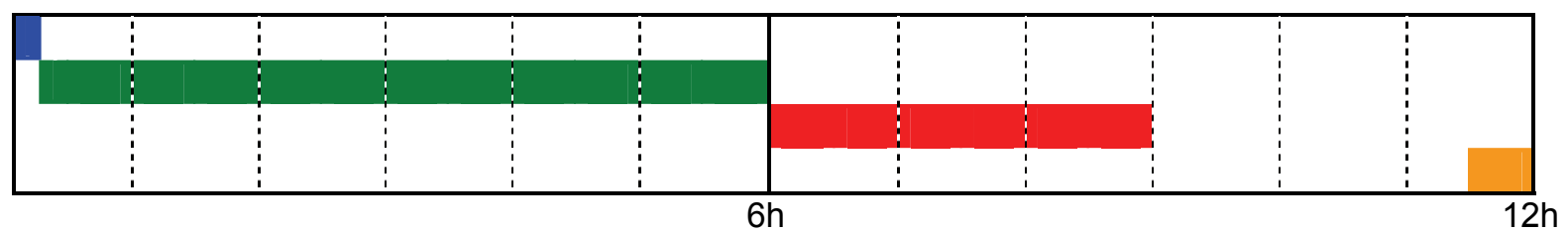

Figura 13: Representação gráfica do ciclo da Etapa 2: Alimentação; Aeração; Agitação; Descarte.

Como a concentração de biomassa no sistema foi diminuída em aproximadamente 40\% (5,8 gSVT. $\left.l^{-1}\right)$, necessitou-se a adequação de uma nova vazão de ar introduzida no sistema a fim de nitrificar o afluente no tempo desejado, que nesta etapa foi de no máximo 6 horas. Foram testadas três faixas de vazões de ar diferentes: 2 a 3, 3 a 4 e 5 a 6 L.min $^{-1}$. O afluente era alcalinizado com bicarbonato de sódio $\left(\mathrm{NaHCO}_{3}\right)$ de forma que a concentração fosse aproximadamente $1000 \mathrm{mgHCO}_{3}^{-} \cdot l^{-1}$ para que a nitrificação não sofresse limitação por alcalinidade.

$\mathrm{Na}$ fase anóxica, foi adicionada parcela do afluente (de 10 a $20 \%$ do volume útil), com intuito de acelerar o processo desnitrificante. Foram testados dois tipos de afluentes: 
originário de reator sulfetogênico e originário de reator metanogênico (descritos no item 3 do Capítulo 3). O efluente destes dois reatores (sulfetogênico e metanogênico) contém elevadas concentrações de compostos reduzidos e, ao serem adicionados na fase anóxica, após a nitrificação, poderiam favorecer o processo de desnitrificação biológica.

$\mathrm{O}$ agitador mecânico era acionado na fase anóxica com velocidade de $50 \mathrm{rpm}$, apenas para manter o sistema misturado sem provocar grandes perturbações hidrodinâmicas nem incorporação de ar.

\subsubsection{Ensaios com Microsensor}

A fim de se avaliar o perfil de concentração de oxigênio em biofilmes de diferentes suportes, utilizaram-se microsensores em experimentos especialmente realizados para esta finalidade. Estes ensaios foram realizados no Laboratório Avançando de Tratamento de Água e Reuso - LATAR do Departamento de Hidráulica e Saneamento - SHS da Escola de Engenharia de São Carlos - EESC da Universidade de São Paulo - USP, com o auxílio e colaboração do engenheiro e especialista em micro-eletrônica fina Wagner Lamon e do Prof. Titular Roberto Campos da Universidade de São Paulo.

Pequenas amostras de materiais suportes inertes com lodo proveniente de reator nitrificante/desnitrificante foram inoculadas em "célula de fluxo" procedendo-se à medida de oxigênio dissolvido (OD) utilizando-se microsensores. Foram utilizados seis tipos de materiais diferentes: 1 - Polietileno de baixa densidade (PEBD); 2 - Disco plástico comercial; 3 - Espuma de poliuretano; 4 - Carvão mineral; 5 - Carvão vegetal e; 6 - Brita basáltica. Essas pequenas amostras de materiais foram fixadas na célula de fluxo com silicone. A Figura 14 mostra o desenho esquemático da célula de fluxo e suas dimensões e a Figura 15 mostra os materiais suportes fixados na célula de fluxo.

O lodo floculento, proveniente do sistema nitrificante/desnitrificante, foi recirculado, através de bomba peristáltica (marca MILAN ${ }^{\circledR}$ ) e aerado continuamente, durante sete dias. Após esse período, o sistema foi alimentado por 30 dias com efluente sintético que simulava a composição média do reator sulfetogênico para tratamento do efluente industrial da empresa DISSOLTEX. O efluente foi alcalinizado com bicarbonato de sódio e o reator foi mantido e operado a $25{ }^{\circ} \mathrm{C}$. Na Tabela 3 , está descrita a composição do efluente sintético utilizado para a aplicação de microsensores. 
Tabela 3: Água residuária sintética utilizada para os ensaios com microsensor.

\begin{tabular}{lcc}
\hline \multicolumn{1}{c}{ Composto } & Unidade & Valores médios \\
\hline Sulfato & $\operatorname{mgSO}_{4}{ }^{-2} \cdot l^{-1}$ & 700 \\
Nitrogênio Amoniacal & $\mathrm{mgNH}_{4}{ }^{+} \cdot l^{-1}$ & 350 \\
Ácido Acético & $\operatorname{mgHac}^{-1}$ & 1200 \\
Alcalinidade & $\operatorname{mgHCO}_{3}{ }^{-} \cdot l^{-1}$ & 1000 \\
\hline
\end{tabular}

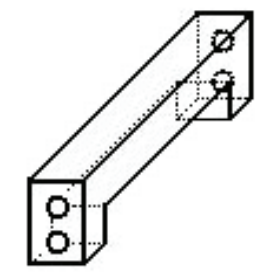

\section{Reator tipo célula de fluxo}

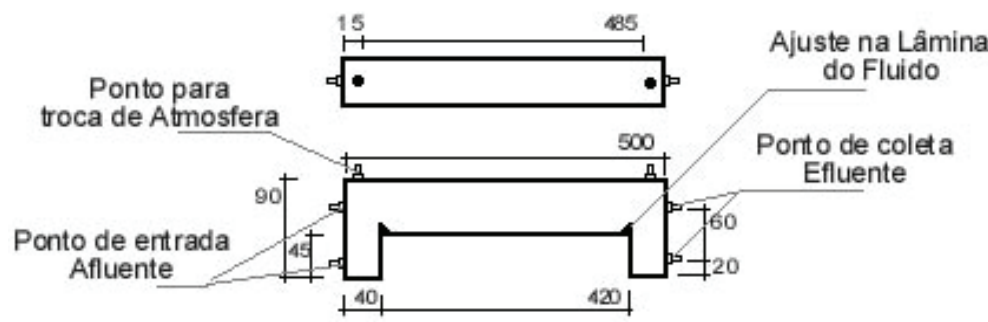

Figura 14: Desenho esquemático do reator tipo célula de fluxo.

Após o $37^{\circ}$ dia do início do experimento, procedeu-se a avaliação do biofilme formado com microsensor de OD. Porém, a concentração de $\mathrm{N}_{-} \mathrm{NH}_{4}{ }^{+}$foi diminuída para 100 mg. $l^{-1}$. A temperatura foi mantida a $25^{\circ} \mathrm{C}$ e a velocidade superficial adotada foi de $5,8 \times 10^{-2}$ $\mathrm{cm} \cdot \mathrm{s}^{-1}$. A Figura 16 apresenta a montagem experimental do reator tipo célula para aplicação de ensaios com microsensor.

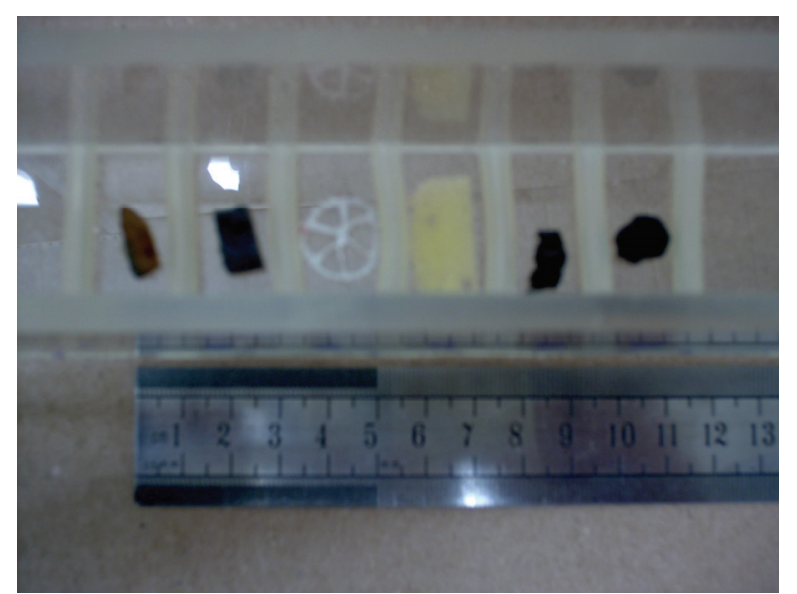

Figura 15: Materiais suportes fixados na célula de fluxo.

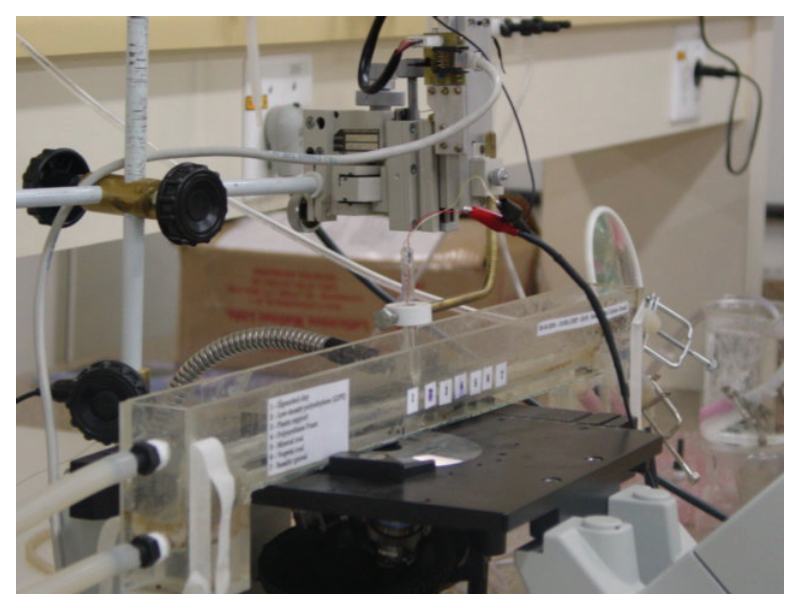

Figura 16: Montagem experimental do reator tipo célula tipo fluxo para aplicação de ensaios com microsensor. 
Os micro-eletrodos foram calibrados na saturação do oxigênio e no ponto de concentração zero de oxigênio dissolvido e foram fixados em servomecanismo, chamado também de micro-manipulador controlado por computador, com deslocamentos verticais de $10 \mu \mathrm{m}$. A cada deslocamento vertical, o servomecanismo pára, o que permite que a leitura seja feita em condições estáveis, armazena os dados em memória e prossegue sucessivamente de forma totalmente automatizada (Lamon, 2007).

Procedeu-se à análise do perfil de OD ao longo da espessura do filme biológico. Para garantir a medida de OD até o final do biofilme foram utilizados microsensores até o rompimento dos mesmos, pela tentativa do microcontrolador descer pelo material suporte inerte. Para a análise dos pontos experimentais de concentração de OD ao longo do filme biológico, foi utilizado o software Origin ${ }^{\circledR}$ versão 6.1. Na Figura 17 e na Figura 18 estão apresentados os suportes inertes fixados no reator tipo célula de fluxo e o sensor de OD preparado para realizar as medidas em biofilme.

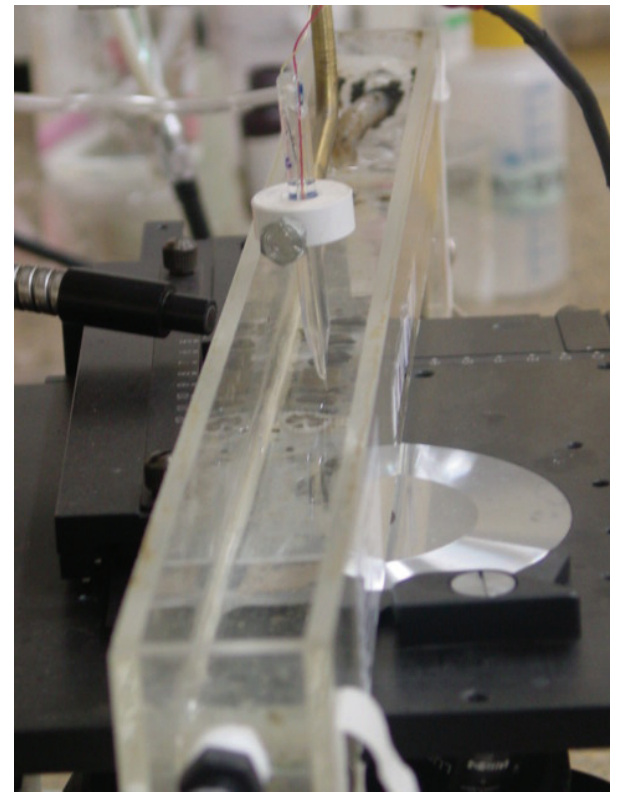

Figura 17: Preparação para a realização do ensaio com microsensor.

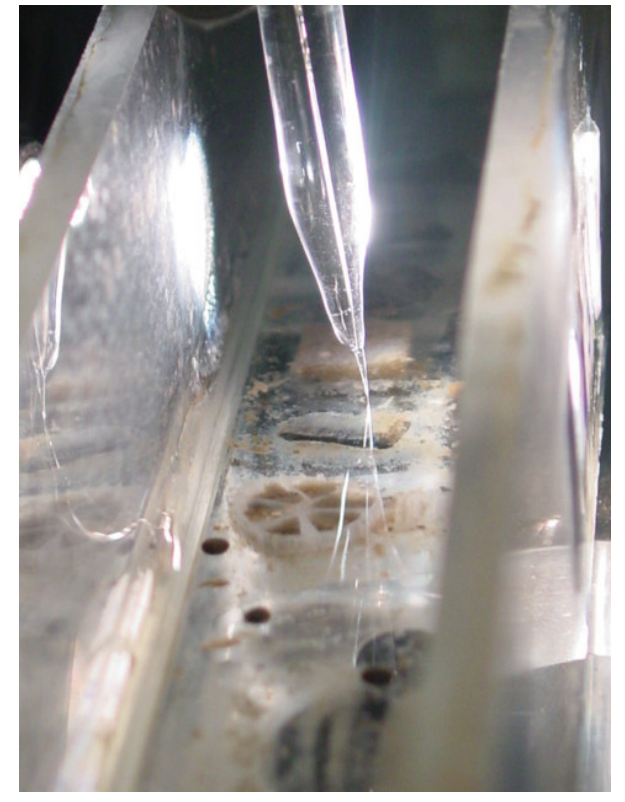

Figura 18: Ensaio de microsensor em andamento.

\subsubsection{ETAPA 3}

Esta etapa foi semelhante à Etapa 2 anterior. No entanto, utilizou-se reator com biomassa imobilizada (descrito no item 1.2 do Capítulo 3) para o tratamento da água residuária. Pretendeu-se a comparação entre os sistemas de biomassa suspensa e este novo 
sistema. Para implementação desta etapa, foram utilizados os resultados dos ensaios com microsensor, para escolha do melhor meio suporte para o processo nitrificante/desnitrificante.

Após a inoculação do reator tipo celular com vários meios suportes (descrito no item 3.6.3 deste capítulo), mediu-se a concentração de oxigênio dissolvido no interior de cada biofilme e determinaram-se as espessuras dos biofilmes aeróbios e anóxicos em cada material suporte inoculado. De posse destes dados, foi possível escolher um material suporte que apresentava características compatíveis com o sistema aeróbio/anóxico utilizado.

Nesta etapa, o ciclo tinha duração de 12 horas, como na Etapa 2 anterior. No entanto, os tempos para enchimento/alimentação e para descarte do reator eram menores e tinham durações iguais (5 minutos). Após a alimentação, o reator era submetido à aeração por aproximadamente 6 horas. Cessada a aeração, ligava-se a recirculação do reator, que se prolongava por aproximadamente seis horas, finalizando com o rápido descarte do efluente, conforme esquematizado na Figura 19 :

\begin{tabular}{|c|c|c|c|c|c|c|c|c|c|}
\hline & & & & & & & & & \\
\\
\hline
\end{tabular}

Figura 19: Representação gráfica do ciclo da Etapa 3: Alimentação; Aeração; Agitação; Descarte.

A vazão de ar utilizada para a fase aeróbia foi a que forneceu os melhores resultados na Etapa 2 anterior (5 a 6 L. $\mathrm{min}^{-1}$ ). $\mathrm{O}$ afluente foi alcalinizado com bicarbonato de sódio $\left(\mathrm{NaHCO}_{3}\right)$ com concentração aproximada de $1000 \mathrm{mgHCO}_{3}^{-} \cdot l^{-1}$.

O reator foi alimentado com aproximadamente 6,5 litros. Assim como na Etapa 2, uma parcela do afluente (de 10 a 20\% do volume útil) foi adicionada na fase anóxica com o intuito de se acelerar o processo desnitrificante e foram testados dois tipos de afluentes: originário de reator sulfetogênico e originário de reator metanogênico.

Diferentemente do reator de biomassa suspensa, utilizado na Etapa 1 e na Etapa 2, o mecanismo utilizado para promover a mistura do sistema era composto por uma bomba dosadora que recirculava a água residuária do topo para o fundo do reator, com uma vazão de 23 L.h $^{-1}$ Nesta etapa, não foi feito o controle da concentração de biomassa, devido a dificuldades operacionais. 


\subsubsection{Ensaios Complementares}

Além das Etapas 1, 2 e 3 estabelecidas, foram realizados ensaios complementares julgados necessários para a elucidação de alguns aspectos importantes dos processos. Ressalve-se que não foram feitas adaptações prévias da biomassa para realização específica destes experimentos. Alguns dos ensaios complementares foram realizados após o término das etapas principais previstas.

\subsubsection{Utilização do efluente diluído da indústria na fase nitrificante}

Foi realizado um perfil temporal de concentração de 6 horas, no reator de biomassa suspensa, a fim de verificar o comportamento das bactérias nitrificantes diante do efluente bruto original da indústria. Com base na concentração do efluente bruto da indústria estudada, diluiu-se $30 \mathrm{~mL}$ deste efluente em 10 litros de água proveniente do sistema de abastecimento d'água local e alcalinizou-se com $30 \mathrm{~g}$ de bicarbonato de sódio. A vazão de ar utilizada neste experimento foi de 5 a 6 L.min ${ }^{-1}$.

\subsubsection{Verificação da nitrificação e do possível processo anammox sem interferentes}

Com a verificação do decaimento de uma pequena parcela de nitrogênio amoniacal no reator com biomassa imobilizada, em algumas fases desnitrificantes, foi realizado um experimento para verificação do consumo de $\mathrm{N}$-amoniacal sem nenhum outro interferente (sulfato, sulfeto, ácidos, etc) e também para avaliação da nitrificação sem possíveis interferentes.

Preparou-se um efluente sintético composto com cloreto de amônia $\left(\mathrm{NH}_{4} \mathrm{Cl}\right)$ e bicarbonato de sódio $\left(\mathrm{NaHCO}_{3}\right)$ de forma que a concentração de nitrogênio amoniacal fosse de $180 \mathrm{mgN}-\mathrm{NH}_{4}{ }^{+} \cdot l^{-1}$ e de bicarbonato fosse de $1500 \mathrm{mgHCO}_{3}^{-} \cdot l^{-1}$. O procedimento adotado foi semelhante ao adotado na Etapa 3.

\subsubsection{Teste de "stripping"}

Este ensaio foi realizado para eliminar a suspeita de grandes perdas de nitrogênio amoniacal por "stripping". Foram utilizados 8 litros de afluente do reator metanogênico, promovendo-se a alcalinização com $10 \mathrm{~g}$ de bicarbonato de sódio. $\mathrm{O}$ frasco contendo esse 
líquido foi autoclavado (30 minutos à $121^{\circ} \mathrm{C}$ e $1,1 \mathrm{~atm}$ ), assim como mangueiras, difusores de ar e rolha, para eliminar todo e qualquer tipo de contaminação biológica, a fim de garantir que as perdas de nitrogênio amoniacal ocorressem apenas por arraste do ar. Utilizou-se a vazão de ar entre 8 e 9 litros por minuto e o $\mathrm{pH}$ do sistema permaneceu entre 9,0 e 9,6. A Figura 20 mostra o aparato utilizado para este experimento.

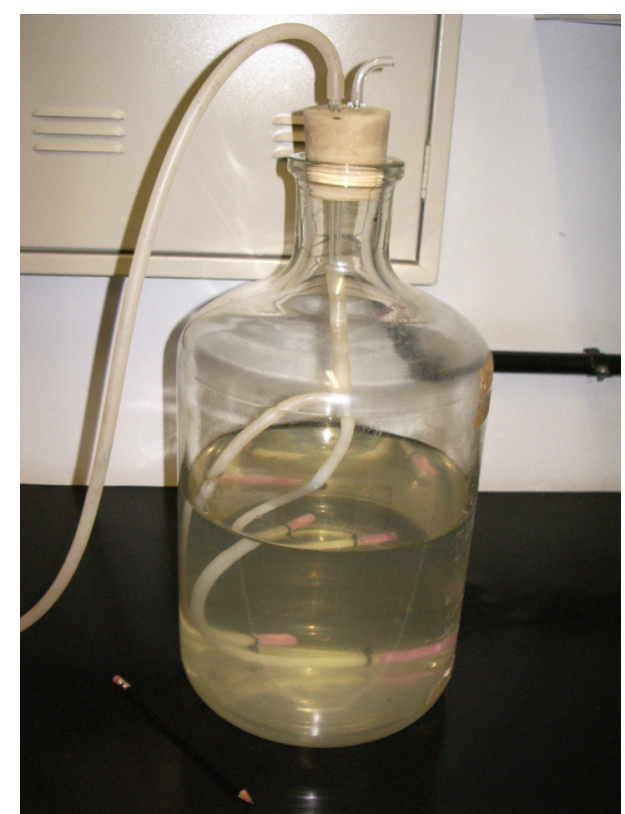

Figura 20: Aparato utilizado para o teste de "Stripping".

\subsection{ANÁLISES FÍSICO-QUÍMICAS}

Para a realização das análises de nitrato, nitrito e nitrito, coletavam-se as amostras que eram inicialmente centrifugadas a $3000 \mathrm{rpm}$ durante 5 minutos. As amostras de nitrato e nitrito eram filtradas em membrana de $45 \mu \mathrm{m}$. Todas as análises e procedimentos analíticos eram executados de acordo com o Standard Methods for the Examination of Water and Wastewater (2000), assim como as análises de sulfato, sulfito, sulfeto e sólidos voláteis totais (SVT). Foram utilizados kits $\mathrm{HACH}^{\circledR}$ para análises de sulfato (SulfaVer ${ }^{\circledR} 4$ AccuVac $($ ), sulfeto (azul de metileno - colorimétrico) e sulfito (Iodométrico). Os parâmetros de análise e os métodos utilizados estão resumidos na Tabela 4. 
Tabela 4: Parâmetros de análise e métodos utilizados.

\begin{tabular}{ll}
\hline \multicolumn{1}{c}{ Análise } & \multicolumn{1}{c}{ Método utilizado } \\
\hline Nitrato $\left(\mathrm{N}_{-} \mathrm{NO}_{3}^{-}\right)$ & Espectofotométrico \\
Nitrito $\left(\mathrm{N}-\mathrm{NO}_{2}{ }^{-}\right)$ & Colorimétrico \\
Nitrogênio Amoniacal $\left(\mathrm{N}-\mathrm{NH}_{4}{ }^{+}\right)$ & Titulométrico \\
Sólidos Voláteis Totais $(\mathrm{SVT})$ & Gravimétrico \\
Alcalinidade & Titulométrico \\
Ácidos Voláteis & Cromatografia Gasosa \\
Sulfato $\left(\mathrm{SO}_{4}{ }^{-2}\right)$ & Colorimétrico \\
Sulfeto $\left(\mathrm{S}^{2-}\right)$ & Colorimétrico \\
Sulfito $\left(\mathrm{SO}_{3}{ }^{-2}\right)$ & Iodométrico \\
\hline
\end{tabular}

As medidas de oxigênio dissolvido no meio foram feitas utilizando-se medidor $\mathrm{ORION}^{\circledR}$ modelo $810 \mathrm{~A}+$ provido por eletrodo de membrana. As medidas de $\mathrm{pH}$ e potencial REDOX foram feitas utilizando-se o medidor ORION ${ }^{\circledR}$ 920A + com duplo canal de leitura, provido de eletrodos acoplados.

Para determinação dos ácidos voláteis orgânicos foi utilizado metodologia de acordo com Moraes et al. (2000), foi utilizado cromatógrafo gasoso Hewlett-Packard ${ }^{\circledR}$, modelo 6890 com coluna HP $\left(\right.$ Innowax $^{\circledR}$ ) de 30 metros de comprimento e com $25 \mu \mathrm{m}$ de diâmetro interno e detector de ionização de chama. Utilizou-se hidrogênio como gás de arraste das amostras com vazão de $30 \mathrm{~mL} \cdot \mathrm{min}^{-1}$. O volume de amostra injetada, previamente preparada, foi de $1 \mu \mathrm{L}$.

\subsection{AVALIAÇÃO DA DIVERSIDADE MICROBIANA}

\subsubsection{Microscopia óptica}

Utilizou-se microscópio ótico Leica ${ }^{\circledR}$ DM LB, com câmera Leica ${ }^{\circledR}$ DC 200 para captura de imagens e o software Image-Pro plus (ver. 4.5.0.19) para o processamento dessas imagens adquiridas. As imagens foram feitas com aproximação de 1500 vezes. As amostras foram examinadas sob contraste de fase e fluorescência.

\subsubsection{Microscopia eletrônica de varredura}

Algumas amostras de lodo foram submetidas aos exames de microscopia eletrônica de varredura $(\mathrm{MEV})$ em microscópio de varredura digital Zeiss ${ }^{\circledR}$ DSM-960. Todas as amostras foram preparadas de acordo com Araújo et al. (2003). 


\subsubsection{Biologia molecular}

A avaliação da diversidade microbiana das amostras foi feita por meio de técnicas de PCR/DGGE no Laboratório de Processos Biológicos - LPB. O DNA foi extraído segundo recomendado por Griffiths et al. (2000). Para amplificação de fragmentos do DNA utilizou-se primers específicos do domínio Bactéria (NIELSEN et al., 1999). Esses fragmentos amplificados foram separados por eletroforese em gel de gradiente desnaturante (DGGE).

Para a comparação dos padrões de bandas de DGGE, utilizou-se a equação de Gillian et al. (1998), a qual dá uma aproximação da similaridade entre duas amostras. Esta equação pode ser visualizada na Equação 12:

$$
C s=\frac{2 \cdot j}{[(a+b)]} .100
$$

Onde: 'Cs' é o grau de similaridade entre as bandas das amostras, 'a' é o número de bandas da amostra 1, 'b' é o número de bandas da amostra 2 e 'j' é o número de bandas em comum entre as duas amostras. 


\section{Capítulo 4}

\section{Resultados e Discussão}

Os resultados experimentais foram dividos em etapas principais (Etapas 1,2 e 3), ensaios complementares e exames microbiológicos. Os fatos mais relevantes, que em muitos experimentos se repetem, são discutidos neste mesmo capítulo no item 4.6. - Comentários Gerais

\subsection{ETAPA 1}

Na primeira etapa, utilizou-se como estratégia de operação um ciclo total de 24 horas, compostas por duas fases aeradas e duas fases não aeradas alternadas, com duração de 6 horas cada uma, começando pela fase aeróbia. Foram testadas três diferentes faixas de vazão de ar aplicada nas fases aeróbias desse sistema com biomassa suspensa: de 2 a 3 , de 4 a 6 e de 8 a 9 L. $\min ^{-1}$.

Pretendeu-se avaliar com esta estratégia a nitrificação autótrofa e a desnitrificação endógena, pois não foi adicionada nenhuma fonte de carbono para a fase desnitrificante. A concentração média de biomassa nesta fase foi de $8,1 \mathrm{gSVT} . l^{-1}(\approx 40 \%$ de volume de lodo em relação ao volume total do reator).

Operou-se o sistema de biomassa suspensa em bateladas sequenciais nesta etapa durante 181 dias. De acordo com os dados de monitoramento, a carga nitrogenada aplicada no sistema chegou a $0,15 \mathrm{kgN}-\mathrm{NH}_{4}{ }^{+} \cdot \mathrm{m}^{-3} \cdot \mathrm{dia}^{-1}$, com eficiência média de $65 \pm 27 \%$, alcançando em alguns casos eficiência máxima de remoção de nitrogênio superior a 90\%. A concentração média afluente de $\mathrm{N}$-amoniacal foi de $134 \pm 23 \mathrm{mgN}-\mathrm{NH}_{4}{ }^{+} . l^{-1}$ e a concentração efluente de nitrato e nitrito foram $14,8 \pm 12 \mathrm{mgN}-\mathrm{NO}_{3}{ }^{-} . l^{-1}$ e $9,9 \pm 12 \mathrm{mgN}-\mathrm{NO}_{2}{ }^{-} \cdot l^{-1}$. A concentração média de ácido acético na entrada foi de $607 \pm 245 \mathrm{mg} . \mathrm{l}^{-1}$.

Observou-se nas fases aeróbias que a nitrificação só ocorreu após o consumo total dos ácidos orgânicos presentes no sistema, provavelmente devido à competição de oxigênio pelas bactérias nitrificantes com os microrganismos aeróbios heterótrofos. 


\subsubsection{ETAPA 1 - Vazão de ar utilizada: 2 a 3 L.min ${ }^{-1}$}

Neste ensaio utilizou-se uma vazão de ar entre 2 e 3 litros por minuto injetada no sistema. Pode-se observar neste caso que a e eficiência de remoção de nitrogênio foi muito baixa, aproximadamente 35\%. De acordo com a Figura 21, as concentrações de nitrato e nitrito foram muito baixas em todos os períodos e não foi observada nenhuma grande alteração destes compostos em todo o ensaio. Nos dois períodos anóxicos a concentração de nitrogênio amoniacal não foi alterada significativamente.

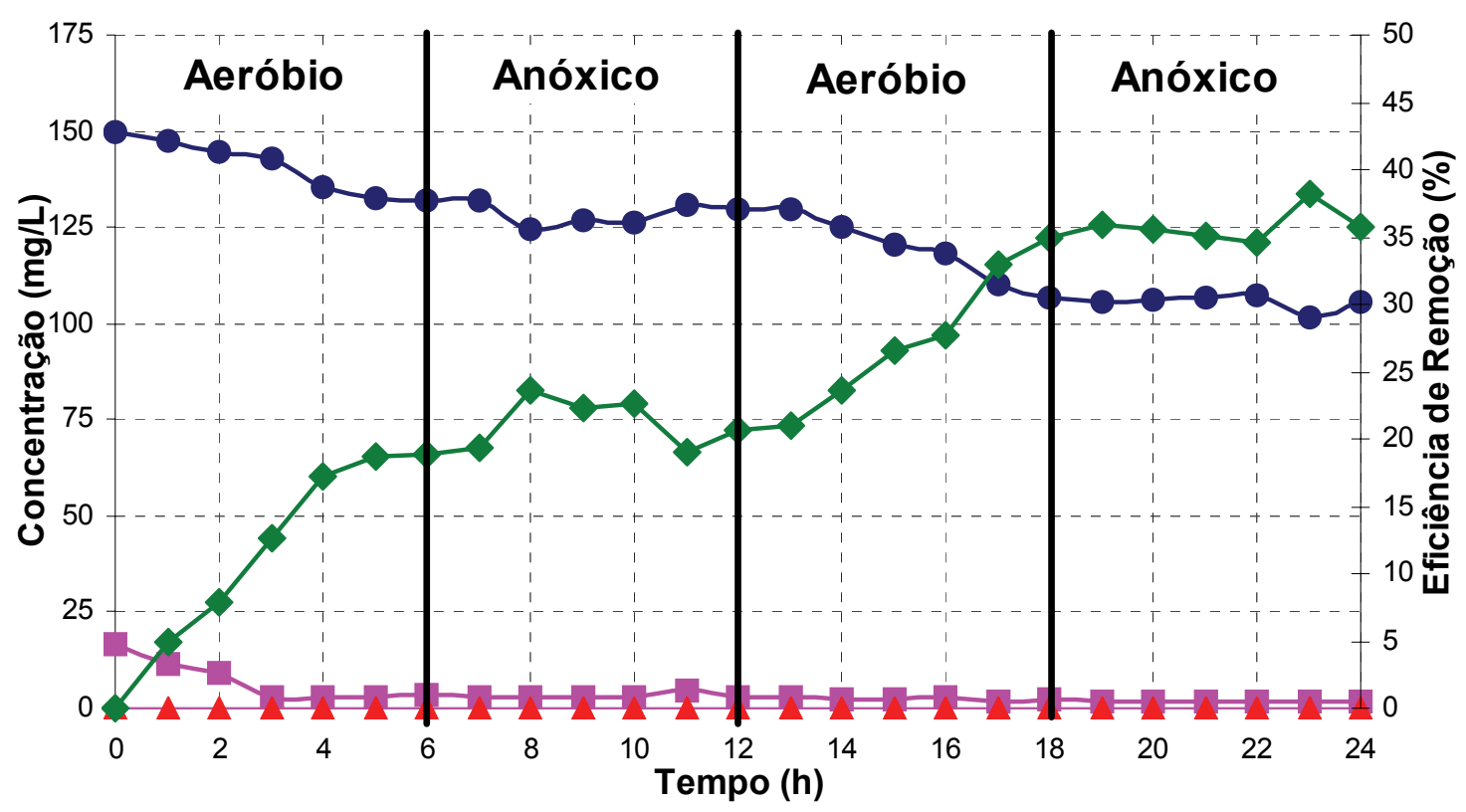

Figura 21: Perfil temporal de 24 horas de compostos de nitrogênio realizado na Etapa 1 com vazão de ar

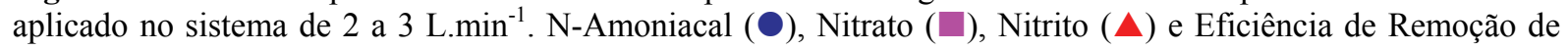
Nitrogênio $(\diamond)$.

Observa-se ainda, na Figura 21, que apesar das concentrações de nitrato e nitrito, nos períodos aeróbios, não serem perceptíveis, pode estar ocorrendo a nitrificação e a desnitrificação endógena simultânea, tendo em vista os pequenos acréscimos de eficiência neste período, verificado pelo sensível consumo de nitrogênio amoniacal nestas fases aeradas.

Como neste ensaio utilizou-se baixa vazão de ar (2 a 3 L.min $\left.{ }^{-1}\right)$, pode ter ocorrido, mesmo na presença de oxigênio, a redução de nitrato e nitrito. A desnitrificação no período aeróbio pode se confirmar com o desaparecimentto de uma parte do nitrato afluente. Neste perído, houve a presença de ácidos que podem ter sido utilizados pelas bactérias desnitrificantes para a redução dos compostos oxidados de nitrogênio. 
Observa-se a remoção do $\mathrm{N}$-amoniacal apenas na fase aeróbia. $\mathrm{Na}$ fase anóxica as concentrações de nitrato e nitrito não se alteraram, embora essas concentrações fossem muito baixas.

A velocidade de nitrificação, ou de conversão de nitrogênio amoniacal, na presença de ácidos $\left(3,57 \mathrm{mg} \mathrm{N}-\mathrm{NH}_{4}{ }^{+} \cdot l^{-1} \cdot \mathrm{h}^{-1}\right)$, foi menor que na nitrificação na ausência de ácidos $(4,70 \mathrm{mg}$ $\left.\mathrm{N}-\mathrm{NH}_{4}{ }^{+} \cdot l^{-1} \cdot \mathrm{h}^{-1}\right)$.

Para dar maior consistência aos dados obtidos, foi proposto um modelo simples e genérico para a remoção de nitrogênio. Este modelo é composto pelas fases nitrificante e denitrificante e foi aplicado tanto nas fases aeróbias quanto nas fases anóxicas, na presença e na ausência de ácidos voláteis. Com este modelo é possível vislumbrar variações imperceptíveis visualmente e pode-se aferir alguns fenômenos que estão ocorrendo no sistema.

Após inúmeros testes realizados para a proposição de um modelo que respondesse adequadamente às variações encontradas no sistema, definiu-se o modelo convencional e às respectivas ordens dos coeficientes para remoção de nitrogênio. Na Figura 22 está o esquema do modelo proposto. Os coeficientes cinéticos k1' de nitritação e k2' de nitratação são coeficientes aparentes de ordem zero, pois dependem da concentração de oxigênio dissolvido no sistema. $\mathrm{O}$ coeficiente $\mathrm{k} 3$, que denota a redução de nitrato a nitrito, é um coeficiente de ordem zero e o coeficiente cinético desnitrificante $\mathrm{k} 4$ é um coeficiente de primeira ordem com dependência da concentração de N-nitrito. Este modelo considera os compostos nitrogenados (N-Amoniacal, N-nitrato e N-nitrito) como limitantes no sistema. As equações do modelo cinético proposto podem ser observadas nas Equações 13 a 15.

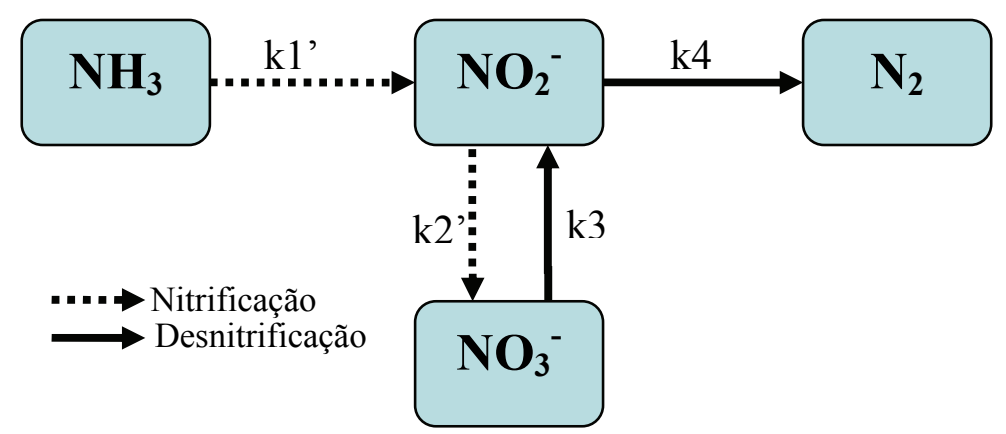

Figura 22: Esquema do modelo convecional para remoção de nitrogênio proposto. 


$$
\frac{\partial\left[N H_{3}\right]}{\partial t}=-k_{1}^{\prime}
$$

$\frac{\partial\left[N O_{2}^{-}\right]}{\partial t}=+k_{1}^{\prime}-k_{2}{ }^{\prime}+k_{3}-k_{4} \cdot\left[N O_{2}^{-}\right]$

$\frac{\partial\left[N O_{3}^{-}\right]}{\partial t}=+k_{2}^{\prime}-k_{3}$

O sistema das equações diferenciais ordinárias foi resolvido numericamente por planilha computacional baseada no método Runge-Kutta de $4^{\mathrm{a}}$ ordem desenvolvida por Debastiani (2002). O critério de convergência e otimização desta tabela foi modificado e melhorado a fim de propiciar uma solução mais confiável. Considerou-se para esta modificação os valores modulares dos desvios padrões, entre o modelo e os dados experimentais. Foram somados todos os desvios e multiplicados por uma constante arbitrária elevada $9 \times 10^{20}$ e, por meio da ferramenta "Solver" do Microsoft Execel ${ }^{\circledR}$ este valor foi minimizado.

Como dito anteriormente, este é um modelo simplificado que tem suas limitações, pois não considera:

- Efeitos de "stripping" da amônia na fase aeróbia;

- Assimilação de compostos de nitrogênio por microrganismos;

- Intermediários do processo desnitrificante;

- Efeitos hidrodinâmicos presentes no reator.

Apesar destas limitações, o modelo pode nos fornecer indicações importantes sobre o comportamento dos compostos nitrogenados no reator.

Tabela 5: Coeficientes cinéticos obtidos pelo modelo convencional de remoção de nitrogênio aplicado à ETAPA 1 - Vazão de ar utilizada: 2 a 3 L. $\min ^{-1}$

\begin{tabular}{|cccccc|}
\hline & Unidade & $\begin{array}{c}\text { Aeróbio 1 } \\
\text { c/ Ácidos }\end{array}$ & $\begin{array}{c}\text { Anóxico 1 } \\
\text { s/ Ácidos }\end{array}$ & $\begin{array}{c}\text { Aeróbio 2 } \\
\text { s/ Ácidos }\end{array}$ & $\begin{array}{c}\text { Anóxico 2 } \\
\text { s/ Ácidos }\end{array}$ \\
\hline \multirow{2}{*}{$\mathrm{k} 1{ }^{\prime}$} & $\mathrm{mg} \cdot l^{-1} \cdot \mathrm{h}^{-1}$ & 3,136839 & 0,000000 & 3,496403 & 0,000000 \\
\hline $\mathrm{k} 2$ & $\mathrm{mg} \cdot l^{-1} \cdot \mathrm{h}^{-1}$ & 0,036227 & 0,000000 & 0,894046 & 0,000000 \\
\hline $\mathrm{k} 3$ & $\mathrm{mg} \cdot l^{-1} \cdot \mathrm{h}^{-1}$ & 2,646756 & 0,000840 & 1,070630 & 0,080754 \\
\hline $\mathrm{k} 4$ & $\mathrm{~h}^{-1}$ & 90,972386 & 0,200048 & 60,770418 & 0,526581 \\
\hline
\end{tabular}

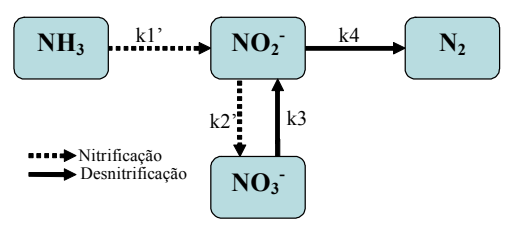


Segundo os coeficientes cinéticos mostrados na Tabela 5, na primeira fase aeróbia (na presença de ácidos voláteis), observa-se que k1' >> k2', portanto, tem-se como produto principal da nitrificação o nitrito. O nitrato formado foi logo convertido a nitrito, pois $\mathrm{k} 3>>$ k2', porém esse nitrito formado, tanto pela nitritação, quanto pela redução de nitrato à nitrito foi imediatamente consumido, pois o coeficiente de primeira ordem $\mathrm{k} 4$ foi muito elevado ( $\mathrm{k} 4$ $\left.=90,972386 \mathrm{~h}^{-1}\right)$. Este fato explica por que as concentrações de nitrato e nitrito foram muito baixas nesta fase aeróbia e, mesmo assim, observou-se o consumo de uma parcela do nitrogênio amoniacal.

Verifica-se pela Tabela 5 que na primeira fase anóxica, os coeficientes k1' e k2' foram iguais a zero, ou seja, não foi identificada a ocorrência da nitrificação. A redução de nitrato a nitrito nesta fase foi muito baixa $\left(\mathrm{k} 3=0,000840 \mathrm{mg} \cdot \mathrm{l}^{-1} \cdot \mathrm{h}^{-1}\right)$ e conjuntamente houve a redução de nitrito à nitrogênio gasoso $\left(\mathrm{k} 4=0,200048 \mathrm{~h}^{-1}\right)$.

$\mathrm{Na}$ segunda fase aeróbia, o valor do coeficiente k1' de nitritação, foi muito semelhante ao coeficiente k1' da primeira fase aeróbia, porém, a nitratação, representada pelo coeficiente k2', foi aproximadamente 25 vezes maior do que na primeira fase aeróbia (na presença de ácidos), indicando que os microrganismos nitratantes são mais suscetíveis à competição por oxigênio, ou seja, os requisitos por oxigênio são maiores para esses microrganismos.

O coeficiente k1', na segunda fase aeróbia, foi aproximadamente 4 vezes o valor do coeficiente $\mathrm{k} 2$ '. Este fato indica que a nitrificação se deu basicamente a nitrito. $\mathrm{O}$ nitrato formado foi logo convertido para nitrito, pois k3 > k2', devido à redução de nitrato a nitrito. Porém, todo o nitrito formado foi desnitrificado, tendo em vista o alto valor do coeficiente $\mathrm{k} 4$ $\left(60,770418 \mathrm{~h}^{-1}\right)$. Por esse motivo, as concentrações de nitrato e nitrito foram muito baixas, verificando-se acréscimo de eficiência pelo consumo de nitrogênio amoniacal.

Na segunda fase anóxica, o coeficiente k1' foi igual a zero, pois não houve a presença de nitrogênio amoniacal. Observa-se também que o coeficiente k2' foi nulo, ou seja, não está ocorrendo a nitratação, o que era bastante previsível. Observa-se também que a atividade desnitrificante nesta fase anóxica foi mais intensa do que na primeira fase anóxica.

Como mostrado na Tabela 5, a desnitrificação endógena ocorreu mais ativamente nas fases aeróbias do que nas fases anóxicas. Não se sabe exatamente o por quê deste fenômeno. 


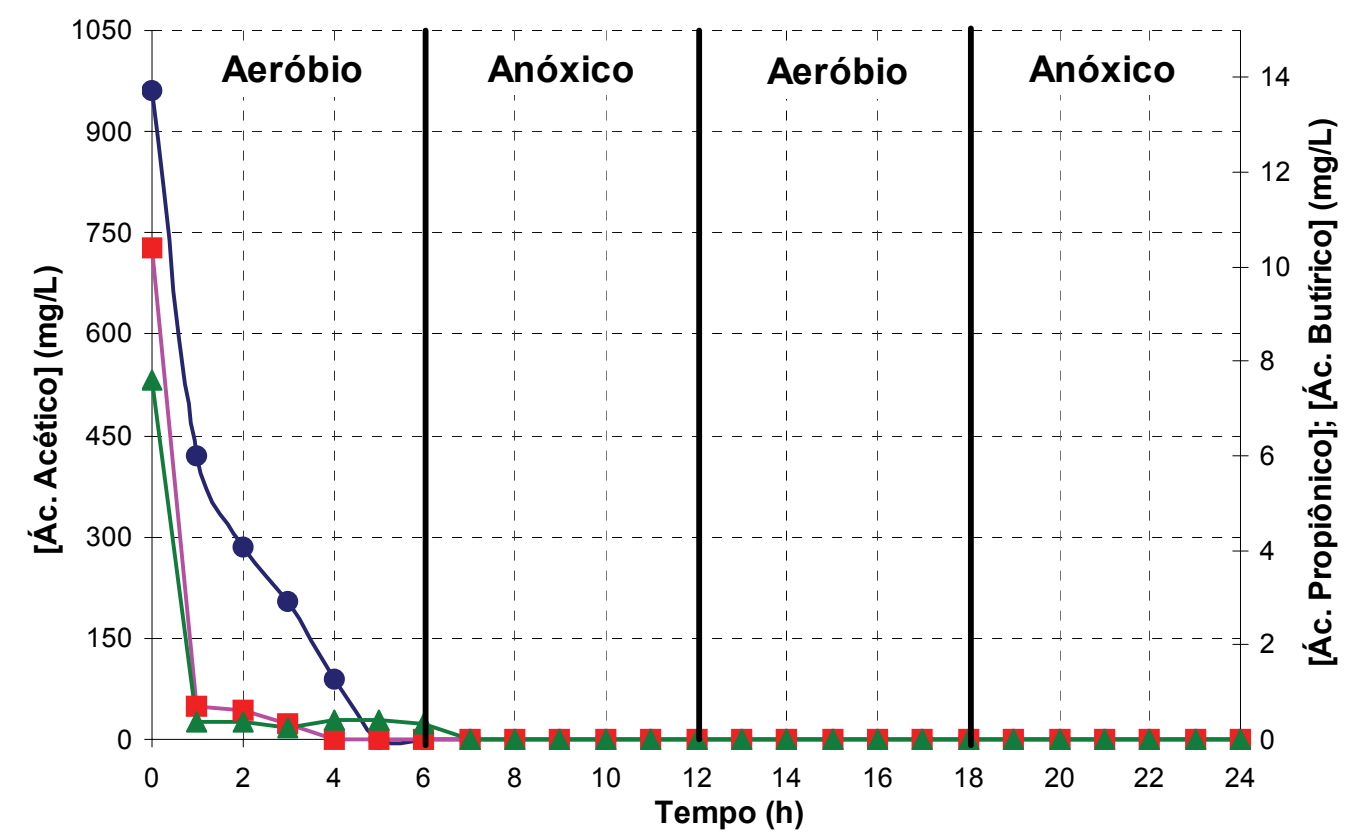

Figura 23: Perfil temporal de 24 horas de ácidos orgânicos realizado na Etapa 1 com vazão de ar aplicado no

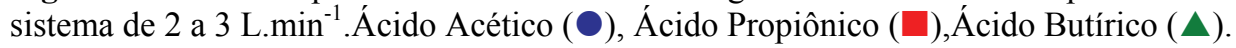

Neste ensaio, apesar de não verificar-se explicitamente a nitrificação, devido provavelmente à baixa aeração no sistema (vazão de ar entre 2 a 3 L.min ${ }^{-1}$ ), observa-se, conforme Figura 23, que houve o consumo de ácidos voláteis. A concentração de ácido acético afluente foi relativamente alta, em torno de $1000 \mathrm{mg} . l^{-1} \mathrm{e}$, no entanto, a aeração baixa foi suficiente para consumir estes ácidos. Pode-se aferir com esta constatação que os requisitos de oxigênio para as bactérias aeróbias heterótrofas são menores do que para as bactérias nitrificantes.

\subsubsection{ETAPA 1 - Vazão de ar utilizada: 4 a 6 L.min ${ }^{-1}$}

Neste ensaio utilizou-se uma vazão de ar entre 4 e 6 litros por minuto injetada no sistema. De acordo com a Figura 24, os comportamentos do nitrato e do nitrito e suas concentrações foram semelhantes (coeficiente de correlação igual a 0,99). A eficiência de remoção de nitrogênio com esta estratégia chegou à 50\%.

Observou-se que, no primeiro período anóxico, nada ocorreu com as concentrações de $\mathrm{N}$-amoniacal, nitrato e nitrito. No último período anóxico, apesar de não se ter nenhuma fonte de carbono adicionada, verificou-se uma sensível queda do nitrato e do nitrito devido, provavelmente, à desnitrificação endógena. 


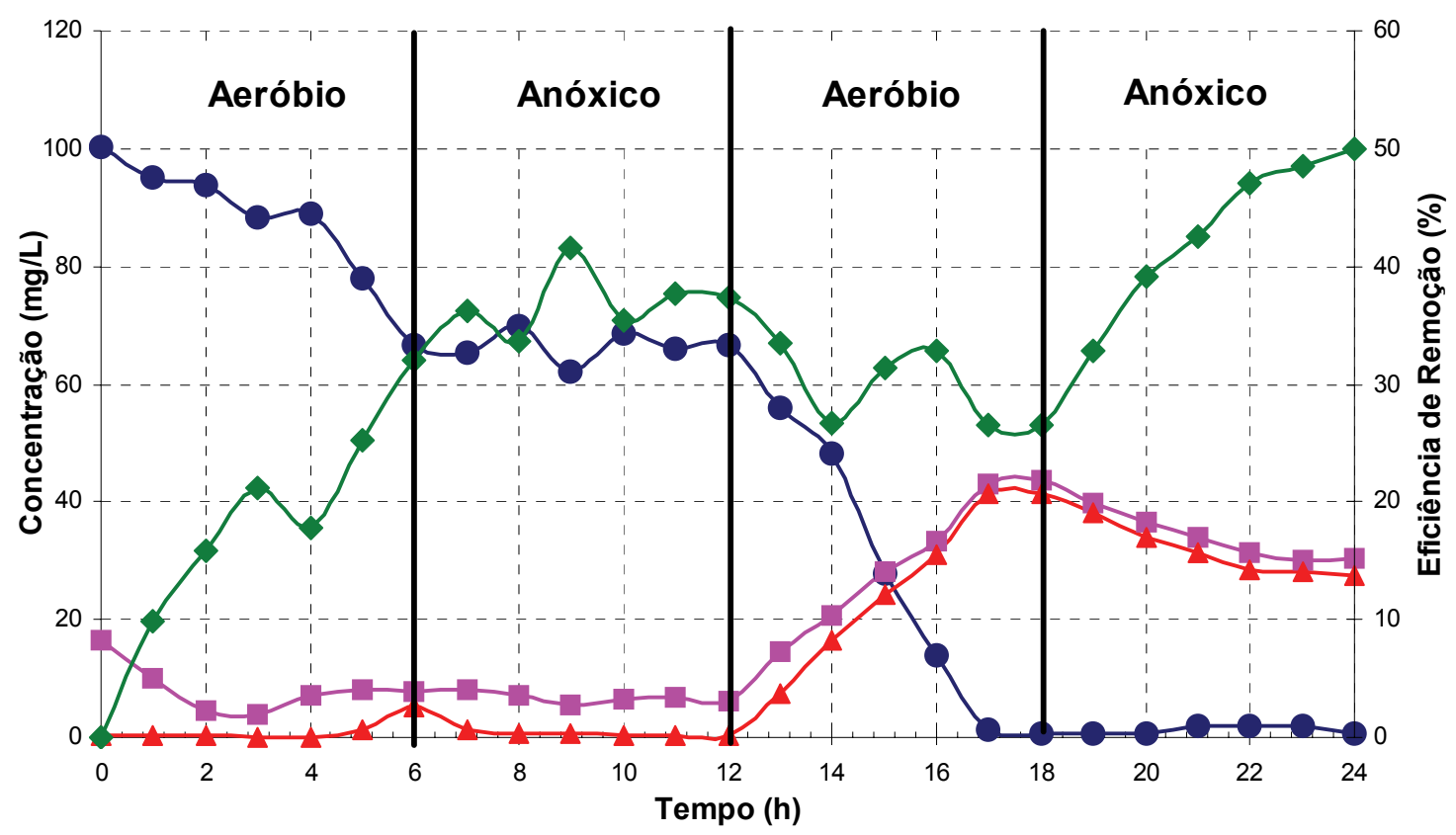

Figura 24: Perfil temporal de 24 horas de compostos de nitrogênio realizado na Etapa 1 com vazão de ar

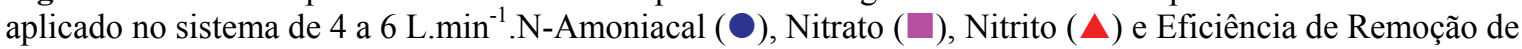
Nitrogênio $(\diamond)$.

No segundo período aeróbio observou-se a conversão do nitrogênio amoniacal restante em nitrato e nitrito. Porém, ao contrário do esperado, no primeiro período aeróbio, nota-se que houve um acréscimo de eficiência, devido ao decaimento do nitrogênio amoniacal. Este fato, foi inusitado, porém pode-se levantar algumas hipóteses para tal fenômeno, pois o acréscimo de eficiência nesta fase supera $30 \%$, o que foi bastante expressivo.

De acordo o ensaio complementar mostrado na Figura 66 (teste de "stripping"), a perda de nitrogênio por "stripping" é de aproximadamente 9,5\%, o que não justifica esta elevada eficiência de remoção de nitrogênio nesta fase aeróbia ao "stripping".

Uma hipótese para o consumo "inexplicável” de nitrogênio amoniacal sem a respectiva contrapartida de nitrato e nitrito é que pode ter ocorrido a desnitrificação simultaneamente à nitrificação. O que sustenta esta hipótese foi que, de acordo com a Figura 25 , tem-se um potencial de óxido redução negativo muito acentuado e, de acordo com a Figura 26, até aproximadamente a quarta hora do início da aeração, havia ácidos voláteis disponíveis no meio líquido. Portanto, apesar de haver oxigênio dissolvido, o meio líquido pode oferecer às bactérias desnitrificantes um poder redutor elevado para a ocorrência do processo desnitrificante. Verifica-se este fenômeno nas duas horas iniciais, que houve o desaparecimento de uma parcela do nitrato afluente. 
Tabela 6: Coeficientes cinéticos obtidos pelo modelo convencional de remoção de nitrogênio aplicado à ETAPA 1 - Vazão de ar utilizada: 4 a 6 L.min ${ }^{-1}$.

\begin{tabular}{|c|c|c|c|c|c|c|c|}
\hline \multirow{5}{*}{$\frac{\frac{0}{\pi}}{\frac{\pi}{g}}$} & & Unidade & $\begin{array}{l}\text { Aeróbio } 1 \\
\text { c/ Ácidos }\end{array}$ & $\begin{array}{c}\text { Aeróbio } 1 \\
\text { s/ Ácidos }\end{array}$ & $\begin{array}{l}\text { Anóxico } 1 \\
\text { s/ Ácidos }\end{array}$ & $\begin{array}{c}\text { Aeróbio } 2 \\
\text { s/ Ácidos }\end{array}$ & $\begin{array}{l}\text { Anóxico } 2 \\
\text { s/ Ácidos }\end{array}$ \\
\hline & $\mathrm{k} 1$ ' & $\mathrm{mg} \cdot \mathrm{l}^{-1} \cdot \mathrm{h}^{-1}$ & 3,842245 & 10,628901 & 0,091816 & 13,227940 & 0,000000 \\
\hline & $\mathrm{k} 2^{\prime}$ & $\mathrm{mg} \cdot \mathrm{l}^{-1} \cdot \mathrm{h}^{-1}$ & 0,760145 & 1,283213 & 0,000599 & 6,178077 & 0,000000 \\
\hline & k3 & $\mathrm{mg} \cdot l^{-1} \cdot \mathrm{h}^{-1}$ & 2,879159 & 0,790462 & 0,234061 & 0,000000 & 3,234389 \\
\hline & $\mathrm{k} 4$ & $\mathrm{~h}^{-1}$ & 25,525022 & 2,457962 & 1,294298 & 0,000000 & 0,175211 \\
\hline
\end{tabular}

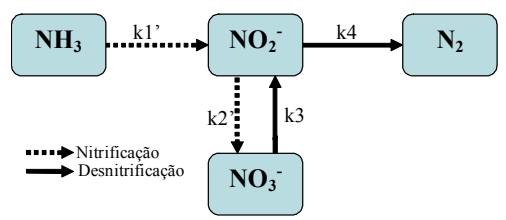

De acordo com a Tabela 6, a nitrificação na primeira fase aeróbia, mostrada pelos coeficientes k1' e k2', na presença de ácidos voláteis, foi inferior (na ordem de 4 vezes menor) à nitrificação nesta mesma fase na ausência dos ácidos. Apesar da presença de oxigênio, observou-se pelos coeficientes k3 e k4 que houve a denitrificação simultânea com a nitrificação. Verificou-se que a redução de nitrato a nitrito, representado pelo coeficiente k3, e a desnitrificação, representado pelo coeficiente $\mathrm{k} 4$, foram bastantes superiores na presança de ácidos voláteis, na primeira fase aeróbia.

Os coeficientes k1', na primeira fase aeróbia, foram superiores aos coeficientes k2' nesta mesma fase. Isto significa que o produto principal da nitrificação foi o nitrito (dicutido neste capítulo no item 4.6 - Comentários Gerais). Porém, como o coeficiente k4 na primeira fase aeróbia, na presença de ácidos, foi muito elevado $\left(\mathrm{k} 4=25,525022 \mathrm{~h}^{-1}\right)$, não se identificou a presença de nitrito no sistema, pois a velocidade de consumo foi muito superior à sua produção.

Observa-se na Tabela 6 que, na segunda fase aeróbia, os coeficientes cinéticos k3 e k4 foram iguais a zero, ou seja, não se verificou a desnitrificação. Os coeficientes de ordem zero k1' e k2' nesta fase aeróbia foram bem elevados. O coeficiente k1' (nitritação) foi quase o dobro do coeficiente k2' (nitratação). Isto indica que, nesta fase, a produção de nitrato foi muito semelhante à de nitrito. Comparando-se com a primeira fase aeróbia, na ausência de ácidos voláteis, o coeficiente $\mathrm{k} 1$ ' foi aproximadamente $20 \%$ superior na segunda fase aeróbia e a nitratação, caracterizada por k2', foi aproximadamente 4,8 vezes superior na segunda fase aeróbia em relação à primeira.

Verifica-se na segunda fase anóxica que os coeficientes k1' e k2' foram nulos, como esperado. Ainda, segundo a Tabela 6, na segunda fase anóxica, observa-se pelos coeficientes 
k3 e k4 que está ocorrendo a desnitrificação, provavelmente endógena, pois não se adicionou nenhuma fonte de carbono para o processo desnitrificante.

$\mathrm{Na}$ primeira fase anóxica, observa-se que, pelos coeficientes $\mathrm{k} 3$ e $\mathrm{k} 4$ da Tabela 6 , houve ocorrência da desnitrificação endógena, porém os coeficientes k1' e k2' foram diferentes de zero, apesar de serem bem inferiores em relação aos dos períodos aeróbios. Este fato foi inusitado, pois induz a pensar que está havendo a nitrificação na ausência de oxigênio e isto é teoricamente improvável.

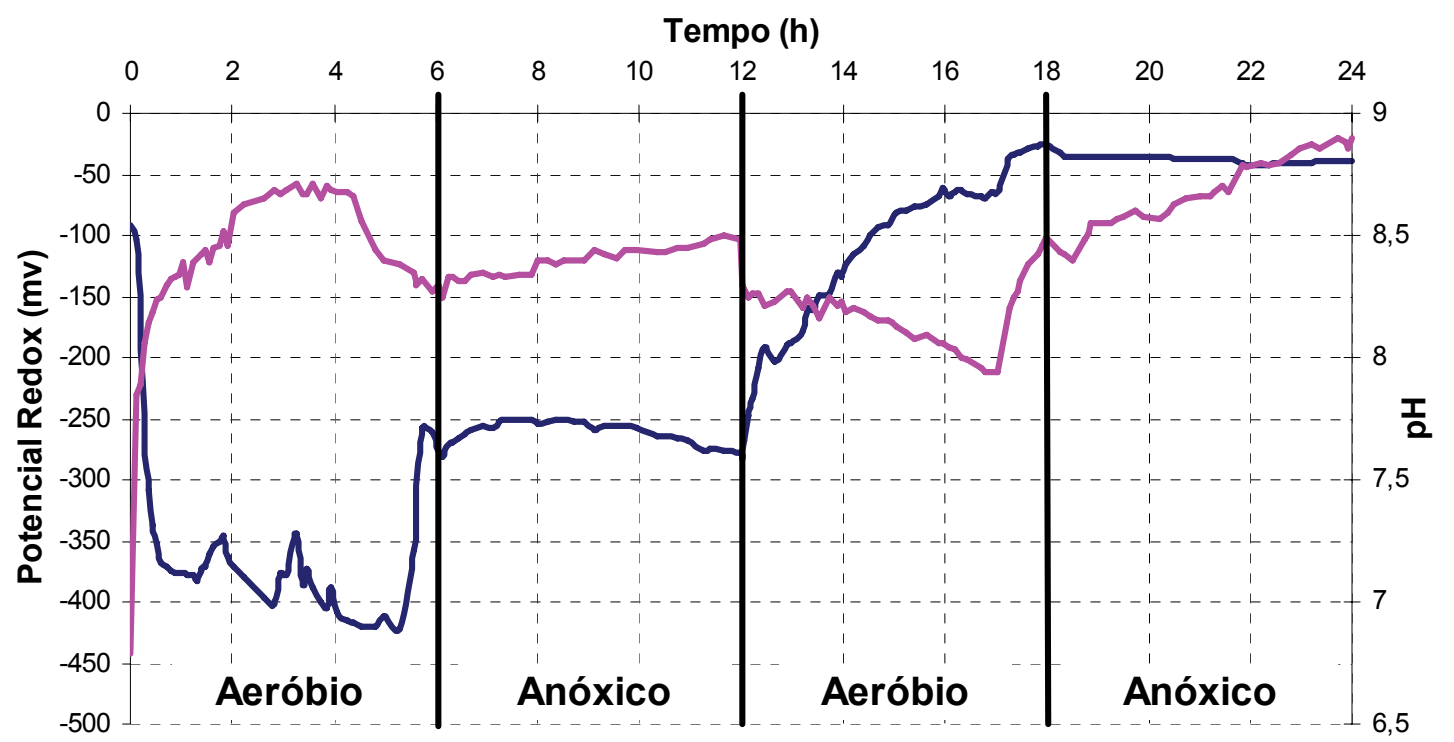

Figura 25: Perfil temporal de 24 horas de compostos $\mathrm{pH}$ e potencial Redox realinado na Etapa 1 com vazão de ar aplicado no sistema de 4 a 6 L.min ${ }^{-1}$ - Potencial Redox - $\mathrm{pH}$.

Com o início da aeração, conforme a Figura 25, houve um aumento brusco do potencial de óxido-redução e uma queda acentuada do pH. Em boa parte do segundo período aeróbio (de $12 \mathrm{~h}$ à $15 \mathrm{~h}$ ), o potencial REDOX teve uma pequena queda. O esperado seria um aumento do potencial REDOX, pois neste período houve constantemente o fornecimento de oxigênio, que é um composto com elevado potencial de óxido-redução.

Após o consumo dos ácidos voláteis, próximo do tempo 4 horas (Figura 26), observou-se uma brusca queda do potencial de oxido-redução. Observou-se também que no primeiro período anóxico houve um pequeno aumento gradativo do potencial REDOX e no segundo período anóxico houve aumento mais significativo.

Neste mesmo segundo período aeróbio, observa-se, ainda na Figura 25, no tempo 17 horas, uma elevação brusca do potencial REDOX coincidente com o consumo total do nitrogênio amoniacal e os picos de concentração de nitrato e nitrito. Este fenômeno pode ser 
importante, tendo em vista o controle operacional do tratamento terciário por um método simplificado, podendo por exemplo, indicar os tempos necessários para o cessamento de aeração.

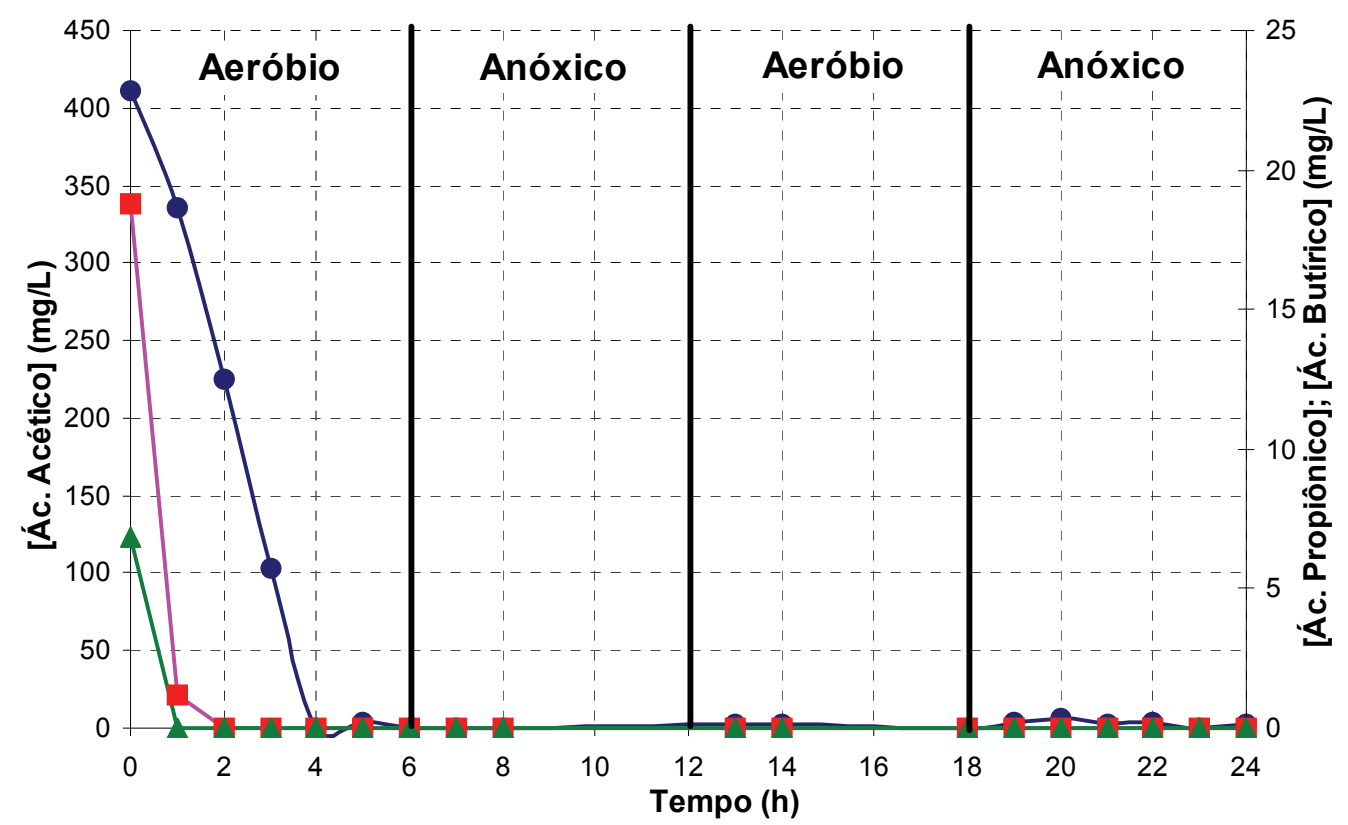

Figura 26: Perfil temporal de 24 horas de ácidos orgânicos realizado na Etapa 1 com vazão de ar aplicado no

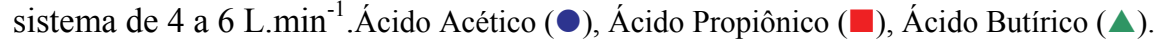

Observa-se ainda na Figura 24 conjuntamente com a Figura 26, que a velocidade de consumo de nitrogênio amoniacal (nitrificação) na presença de ácidos foi inferior $(3,7 \mathrm{mg} \mathrm{N}$ $\left.\mathrm{NH}_{4}{ }^{+} \cdot l^{-1} \cdot \mathrm{h}^{-1}\right)$ do que sem a presença de ácidos voláteis $\left(11,1 \mathrm{mg} \mathrm{N}-\mathrm{NH}_{4}{ }^{+} \cdot l^{-1} \cdot \mathrm{h}^{-1}\right)$. Após a quarta hora até o final da primeira fase aeróbia, verificou-se um sensível aumento de nitrato.

O consumo de ácidos no período aeróbio, favoreceu o desenvolvimento das bactérias aeróbias heterotróficas com conseqüente aumento de biomassa, requerendo altas concentrações de oxigênio.

\subsubsection{ETAPA 1 - Vazão de ar utilizada: 8 a 9 L.min ${ }^{-1}$}

Neste ensaio utilizou-se vazão de ar entre 8 e 9 litros por minuto injetada no sistema. Pode-se observar neste caso que a eficiência de remoção de nitrogênio foi bastante elevada, superior a 90\%. De acordo com a Figura 27, o nitrato e o nitrito foram consumidos quase que totalmente no último período anóxico. As concentrações de nitrato e nitrito, bem como seus comportamentos, foram muito semelhantes (coeficiente de correlação igual a 0,98 ). 
Observa-se na Figura 27, que o nitrogênio amonical foi completamente convertido na primeira fase aeróbia. Na segunda fase aeróbia, não foram observadas grandes variações das concentrações de nitrato e nitrito, pois não havia $\mathrm{N}$-amonical disponível para oxidação. Nas fases anóxicas notou-se um consumo de nitrato e nitrito sem a adição de uma fonte de carbono, indicando a desnitrificação endógena.

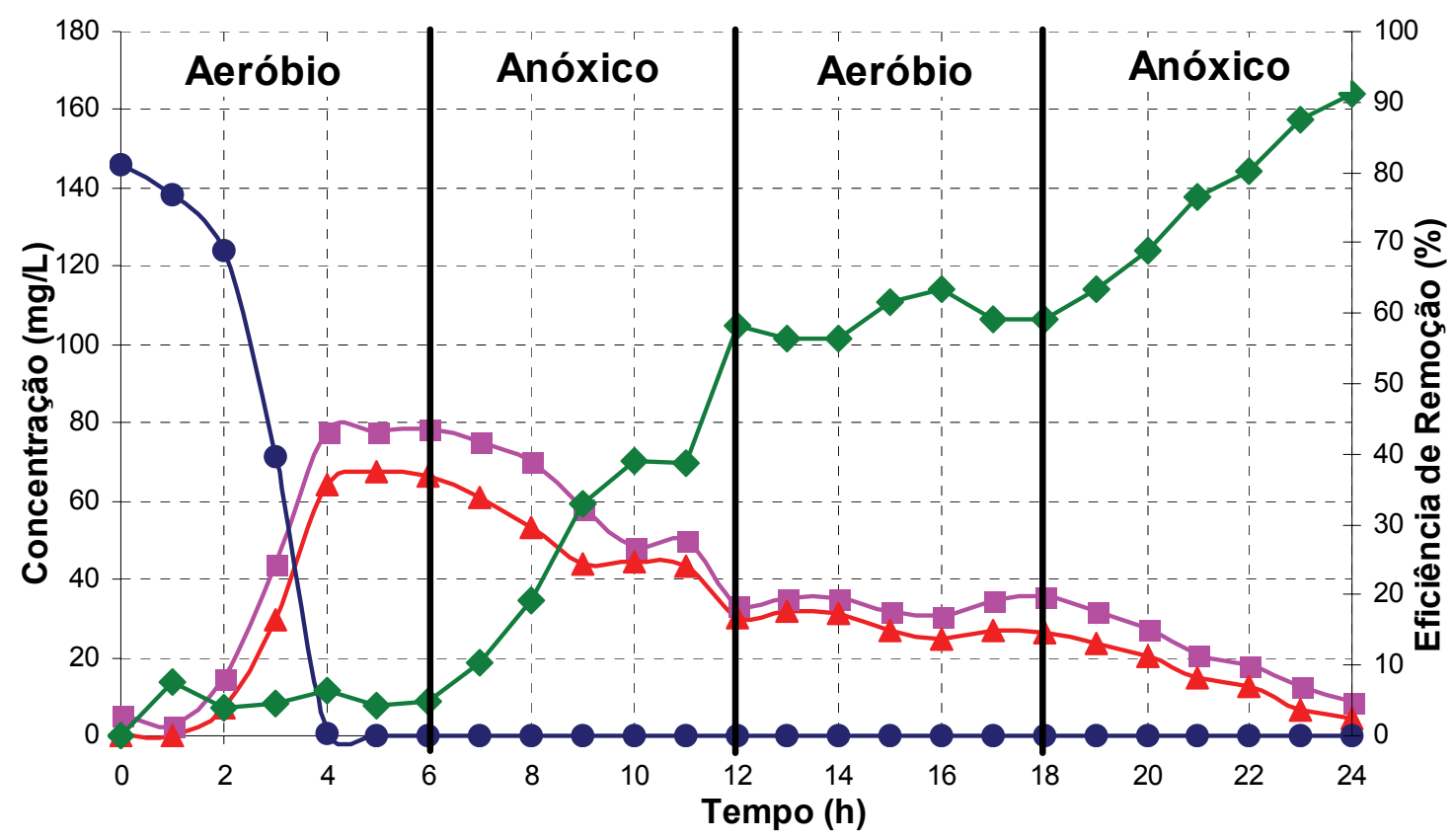

Figura 27: Perfil temporal de 24 horas de compostos de nitrogênio realizado na Etapa 1 com vazão de ar

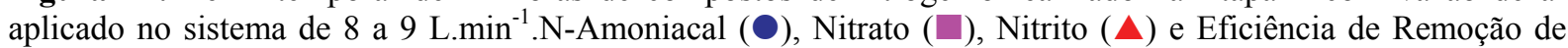
Nitrogênio $(\diamond)$.

Verifica-se ainda, segundo a Figura 27, que o acréscimo de eficiência de remoção de nitrogênio se dá basicamente nas fases anóxicas. Nas fases aeróbias não foram constatados acréscimos de eficiências significativos, indicando, portanto, apenas a remoção de compostos de nitrogênio nesta fase, como esperado.

Tabela 7: Coeficientes cinéticos obtidos pelo modelo convencional de remoção de nitrogênio aplicado à ETAPA 1 - Vazão de ar utilizada: 8 a 9 L. $\min ^{-1}$

\begin{tabular}{|c|c|c|c|c|c|c|c|}
\hline \multirow{5}{*}{ 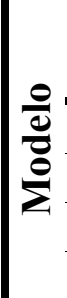 } & & Unidade & $\begin{array}{l}\text { Aeróbio } 1 \\
\text { c/ Ácidos }\end{array}$ & $\begin{array}{l}\text { Aeróbio } 1 \\
\text { s/ Ácidos }\end{array}$ & $\begin{array}{l}\text { Anóxico } 1 \\
\text { s/ Ácidos }\end{array}$ & $\begin{array}{c}\text { Aeróbio } 2 \\
\text { s/ Ácidos }\end{array}$ & $\begin{array}{l}\text { Anóxico } 2 \\
\text { s/ Ácidos }\end{array}$ \\
\hline & $\mathrm{k} 1{ }^{\prime}$ & $\mathrm{mg} \cdot \mathrm{l}^{-1} \cdot \mathrm{h}^{-1}$ & 7,960832 & 59,517944 & 0,000000 & 0,000000 & 0,000000 \\
\hline & $\mathrm{k} 2$ ' & $\mathrm{mg} \cdot l^{-1} \cdot \mathrm{h}^{-1}$ & 4,468382 & 31,737072 & 0,000000 & 0,000000 & 0,000000 \\
\hline & k3 & $\mathrm{mg} \cdot \mathrm{l}^{-1} \cdot \mathrm{h}^{-1}$ & 0,000000 & 0,000000 & 6,343904 & 0,756929 & 4,511347 \\
\hline & $\mathrm{k} 4$ & $\mathrm{~h}^{-1}$ & 0,000000 & 0,000000 & 0,220446 & 0,018578 & 0,465553 \\
\hline
\end{tabular}


$\mathrm{Na}$ Tabela 7 verifica-se, pelos coeficientes cinéticos k1' e k2' que a nitrificação na primeira fase aeróbia, na ausência de ácidos voláteis, foi bem superior (aproximadamente 7,5 vezes maior) do que na presença destes ácidos, provavelmente devido à competição por oxigênio dos microrganismos aeróbios heterotróficos com as bactérias nitrificantes. $\mathrm{O}$ coeficiente $\mathrm{k} 2$ ' foi aproximadamente $50 \%$ do coeficiente $\mathrm{k} 1$ ' na primeira fase aeróbia. Isto significa que quase $50 \%$ do nitrito formado foi oxidado à nitrato, obtendo como produto da nitrificação nitrato e nitrito com concentrações semelhantes. Nesta fase aeróbia, não foi identificada atividade desnitrificante, pois os coeficientes $\mathrm{k} 3 \mathrm{e} \mathrm{k} 4$ foram iguais a zero.

Nas fases anóxicas, não foi identificado nenhum fenômeno anômalo com os coeficientes k1' e k2', pois, como esperado, estes foram nulos. O coeficiente $\mathrm{k} 4$ na segunda fase anóxica foi quase que o dobro do mesmo coeficiente na fase anóxica anterior, indicando que a velocidade de desnitrificação dobrou na segunda fase anóxica em relação à primeira.

$\mathrm{Na}$ segunda fase aeróbia, os coeficientes $\mathrm{k} 1$ ' e k2' foram nulos, ou seja, não houve a nitritação (conversão de $\mathrm{N}$-amoniacal para nitrito) e nitratação (conversão de nitrito para nitrato), porém observa-se uma baixa redução de nitrato a nitrito $\left(\mathrm{k} 3=0,756929 \mathrm{mg} \cdot \mathrm{l}^{-1} \cdot \mathrm{h}^{-1}\right) \mathrm{e}$ baixa desnitrificação $\left(\mathrm{k} 4=0,018578 \mathrm{~h}^{-1}\right)$, mesmo na presença de oxigênio.

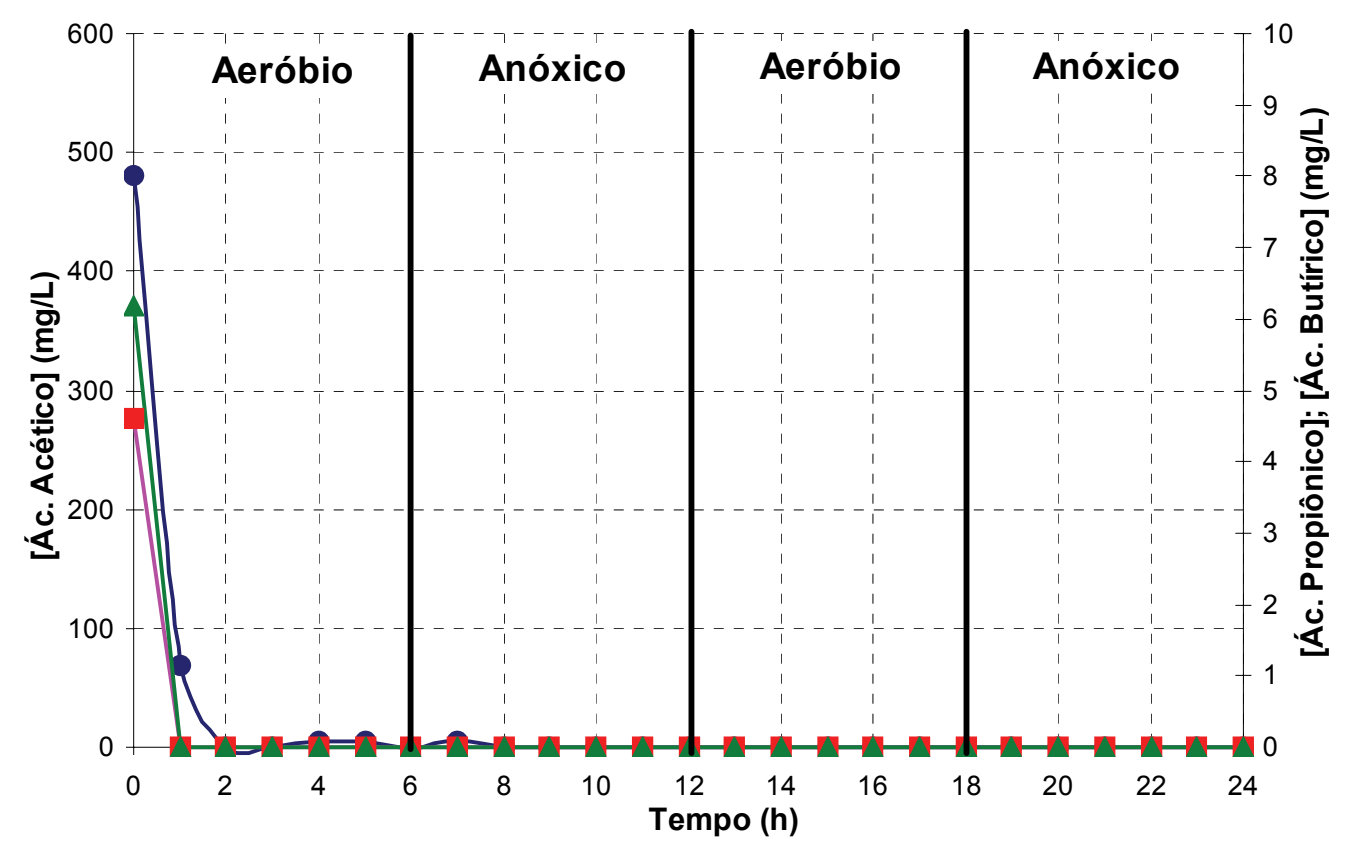

Figura 28: Perfil temporal de 24 horas de ácidos orgânicos realizado na Etapa 1 com vazão de ar aplicado no

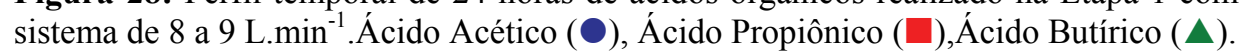

De acordo com a Figura 28, o consumo de ácidos se perfez nas duas primeiras horas. Observa-se também, segundo a Figura 27, que a nitrificação efetivamente ocorreu quando 
esses ácidos foram consumidos. A velocidade de consumo do nitrogênio amoniacal foi menor na presença dos ácidos $\left(11,0 \mathrm{mg} \mathrm{N}-\mathrm{NH}_{4}{ }^{+} \cdot l^{-1} \mathrm{~h}^{-1}\right)$ podendo-se atribuir este fato à competição das bactérias nitrificantes com as bactérias heterotróficas aeróbias. A velocidade de consumo de nitrogênio amoniacal na ausência de ácido foi de $71,1 \mathrm{mg} \mathrm{N}-\mathrm{NH}_{4}{ }^{+} \cdot l^{-1} \cdot \mathrm{h}^{-1}$.

\subsubsection{ETAPA 1 - Vazão de ar utilizada: 8 a 9 L.min ${ }^{-1}$}

Este perfil temporal de concentração (Figura 29) foi realizado como duplicata da melhor condição encontrada nesta primeira etapa da pesquisa (vazão de ar de 8 a 9 L.min $^{-1}$ ). Como se pode observar neste experimento, o comportamento dos compostos nitrogenados no sistema foi muito semelhante ao experimento anterior - Item 4.1.3 (coeficiente de correlação para N-Amoniacal, Nitrato e Nitrito de 0,999; 0,981 e 0,985, respectivamente).

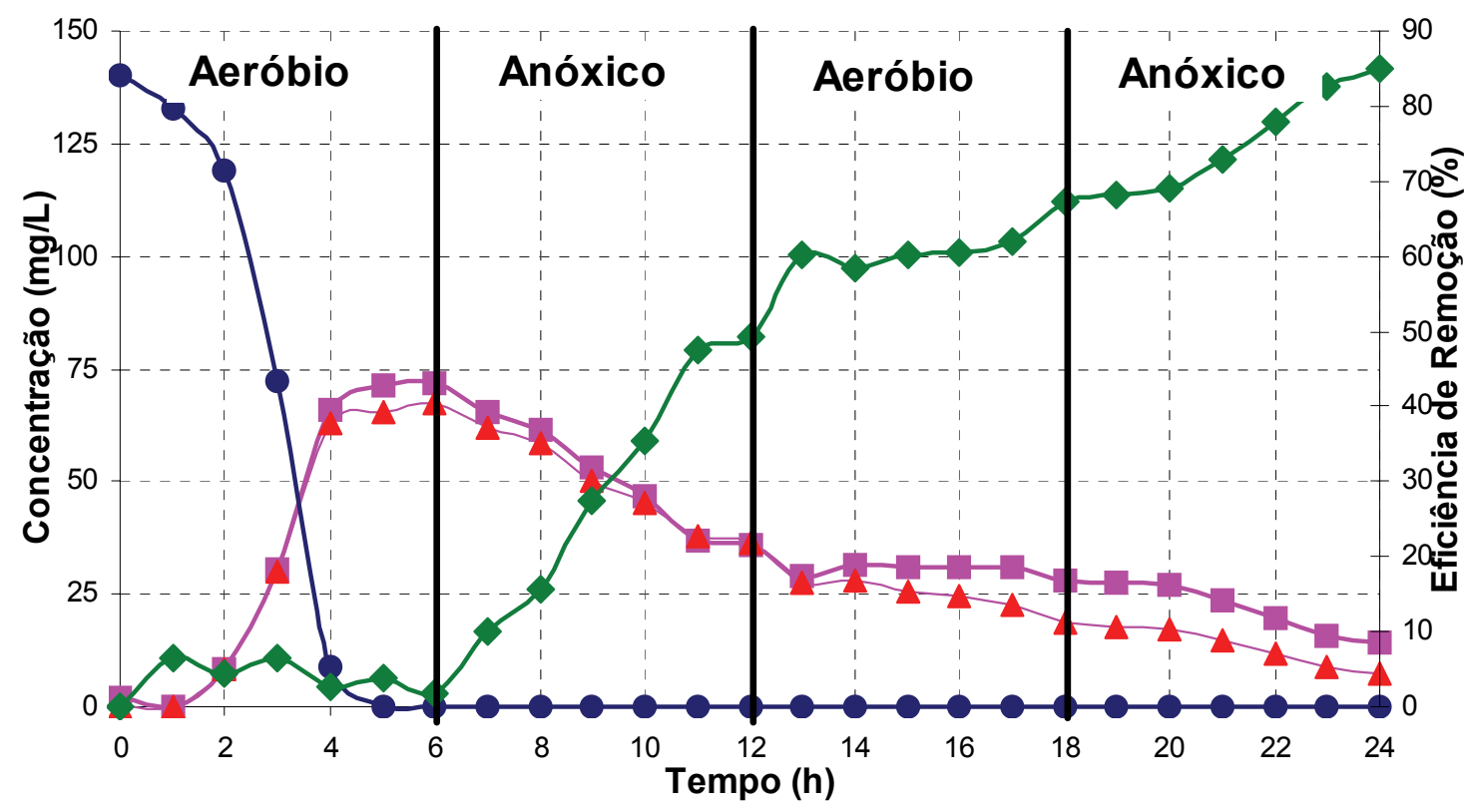

Figura 29: Duplicata do perfil temporal de 24 horas de compostos de nitrogênio realizado na Etapa 1 com vazão de ar aplicado no sistema de 8 a 9 L.min ${ }^{-1}$.N-Amoniacal $(\mathbf{O})$, Nitrato ( $\square$ ), Nitrito ( $\Delta$ ) e Eficiência de Remoção de Nitrogênio $(\diamond)$.

Foi utilizada a vazão de ar de 8 a 9 litros por minuto e esta foi a melhor encontrada nos experimentos anteriores, porém é relativamente alta, e isto foi devido provavelmente à alta concentração de biomassa presente no sistema $\left(8 \mathrm{mgSVT} . l^{-1}\right)$. Segundo as Figura 28 e Figura 30 verifica-se que os ácidos foram consumidos em 2 horas. 
Tabela 8: Coeficientes cinéticos obtidos pelo modelo convencional de remoção de nitrogênio aplicado à ETAPA 1 - Vazão de ar utilizada: 8 a 9 L. min $^{-1}$.

\begin{tabular}{|c|c|c|c|c|c|c|c|}
\hline \multirow{5}{*}{$\frac{\bar{d}}{\bar{c}}$} & & Unidade & $\begin{array}{l}\text { Aeróbio } 1 \\
\text { c/ Ácidos }\end{array}$ & $\begin{array}{l}\text { Aeróbio } 1 \\
\text { s/ Ácidos }\end{array}$ & $\begin{array}{l}\text { Anóxico } 1 \\
\text { s/ Ácidos }\end{array}$ & $\begin{array}{c}\text { Aeróbio } 2 \\
\text { s/ Ácidos }\end{array}$ & $\begin{array}{c}\text { Anóxico } 2 \\
\text { s/ Ácidos }\end{array}$ \\
\hline & $\mathrm{k} 1$ ' & $\mathrm{mg} \cdot \mathrm{l}^{-1} \cdot \mathrm{h}^{-1}$ & 8,923456 & 53,575923 & 0,000000 & 0,000000 & 0,000000 \\
\hline & $\mathrm{k} 2^{\prime}$ & $\mathrm{mg} \cdot l^{-1} \cdot \mathrm{h}^{-1}$ & 2,790660 & 27,468799 & 0,000000 & 0,000000 & 0,000000 \\
\hline & k3 & $\mathrm{mg} \cdot l^{-1} \cdot \mathrm{h}^{-1}$ & 0,000000 & 0,000000 & 6,629146 & 1,276405 & 2,037768 \\
\hline & $\mathrm{k} 4$ & $\mathrm{~h}^{-1}$ & 0,019411 & 0,000000 & 0,233759 & 0,155551 & 0,255770 \\
\hline
\end{tabular}

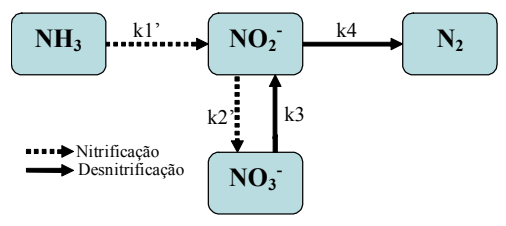

Conforme a Tabela 8, na primeira fase aeróbia na presença de ácidos voláteis, verificase que a oxidação do nitrogênio amoniacal, representado pelo coeficiente cinético k1' e o coeficiente k2' (nitratação) foi aproximadamente 6 e 10 vezes maior, respectivamente, do que os correspondentes coeficientes na mesma fase na ausência de ácidos voláteis. Nesta mesma fase, na ausência de ácidos voláteis, a relação entre k1' e k2' foi aproximadamente $50 \%$, ou seja, metade do nitrito produzido no sistema foi convertida em nitrato.

Mesmo na presença de oxigênio, ocorreu pequena desnitrificação $\left(k 4=0,019411 \mathrm{~h}^{-1}\right)$, porém este fato, na primeira fase aeróbia, se dá quando houve ácidos voláteis disponíveis no meio líquido. Nesta fase, não foi identificada a redução de nitrato a nitrito $(\mathrm{k} 3=0,000000$ $\left.\operatorname{mg} \cdot l^{-1} \cdot h^{-1}\right)$.

$\mathrm{Na}$ primeira fase anóxica, a redução de nitrato à nitrito, denotado pelo coeficiente cinético k3, foi quase 3 vezes maior, comparando-se com a segunda fase anóxica. Observa-se ainda, pela Tabela 8, que o coeficiente k4 (coeficiente cinético de desnitrificação) foi da mesma magnitude nas duas fases anóxicas.

$\mathrm{Na}$ segunda fase aeróbia, observa-se na Tabela 8 , que o coeficiente $\mathrm{k} 1$ ' foi igual a zero, pois não havia a presença de nitrogênio amoniacal para oxidação. O coeficiente k2' também foi nulo, ou seja, não houve a nitratação (conversão de nitrito a nitrato). Apesar da presença de oxigênio nesta fase, observa-se, ainda, a ocorrência da redução de nitrato à nitrito $\left(\mathrm{k} 3=1,276405 \mathrm{mg} \cdot l^{-1} \cdot \mathrm{h}^{-1}\right)$ e da desnitrificação endógena $\left(\mathrm{k} 4=0,155551 \mathrm{~h}^{-1}\right)$. 


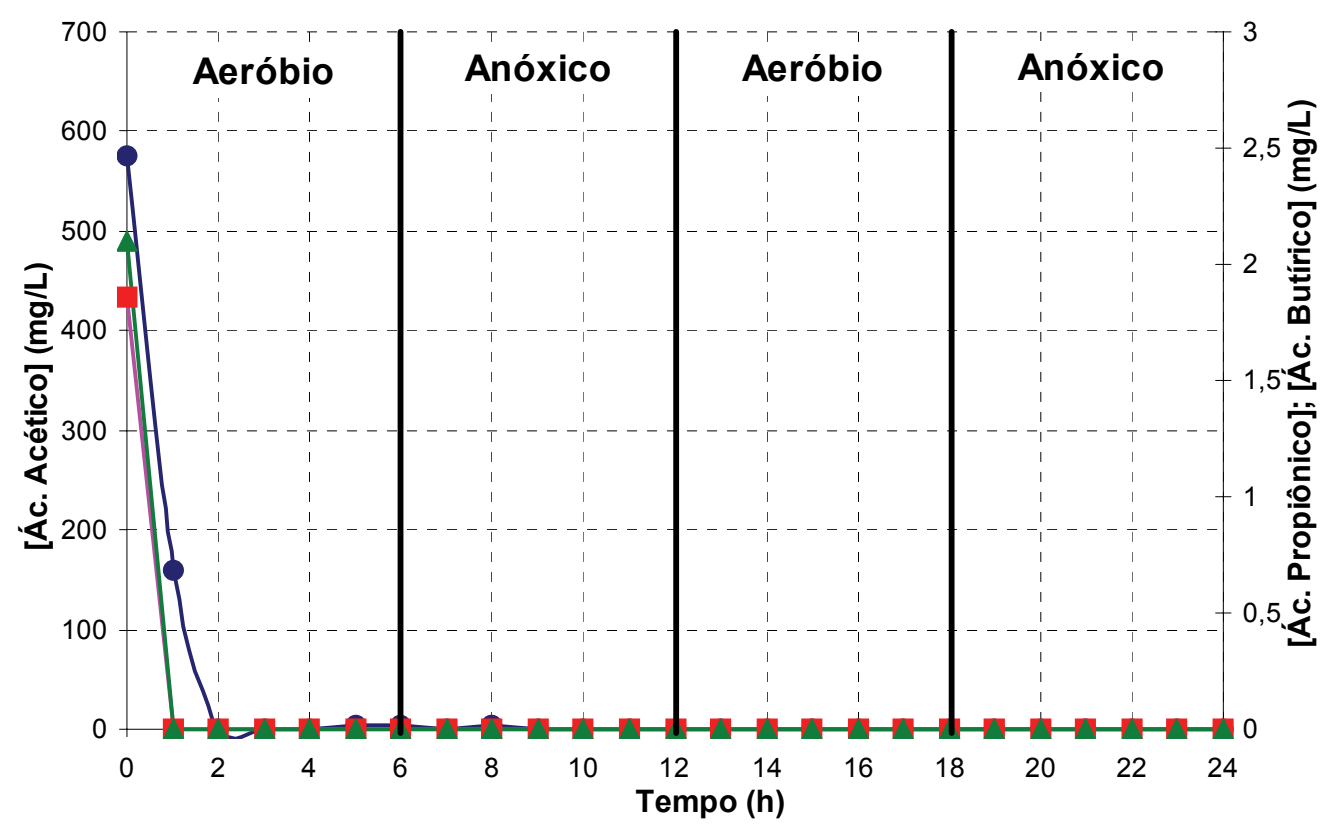

Figura 30: Duplicata do perfil temporal de 24 horas de ácidos orgânicos realizado na Etapa 1 com vazão de ar

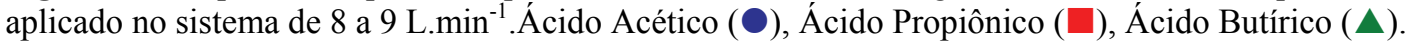

A estratégia inicial de se adotar 4 fases alternadas, aeróbias e anóxicas, com 6 horas cada, perfazendo um ciclo total de 24 horas, sem a adição de fonte de carbono para desnitrificação, mostrou-se viável tecnicamente. Porém, poder-se-ía suprimir a segunda fase aeróbia, resultando em uma única fase aeróbia seguida de uma fase anóxica estendida.

Outro fato relevante é que a concentração de biomassa foi muito elevada $\left(8,1 \mathrm{gSVT} . \mathrm{l}^{-}\right.$ ${ }^{1}$ ), o que exigia uma quantidade de ar fornecida para o sistema muito grande (8 a 9 L. $\left.\mathrm{min}^{-1}\right)$. Isto poderia inviabilizar o sistema terciário, tornando-o muito dispendioso, mesmo com alternativa da desnitrificação endógena.

Diante dos fatos apresentados, decidiu-se suprimir a primeira fase anóxica, visto que, nesta fase, praticamente nada ocorria. Almejou-se também otimizar o tempo necessário ao tratamento e, para isto, foi adicionado posteriormente afluente rico em ácidos voláteis orgânicos e outros compostos reduzidos na fase desnitrificante. Com esta estratégia, pretendeu-se utilizar estes compostos reduzidos, principalmente os ácidos voláteis para a ocorrência da desnitrificação, favorecendo o desenvolvimento de bactérias heterótrofas que realizam a redução de compostos oxidados de nitrogênio. Outra medida foi diminuir em 40 \% a quantidade de biomassa no sistema. 


\subsection{ETAPA 2}

Finalizada a Etapa 1 e dias antes do começo da Etapa 2, após 173 dias de operação, foi aplicada, não intencionalmente, durante aproximadamente 8 dias sucessivos, uma sobrecarga nitrogenada que proporcionou a falência do sistema. A concentração de nitrogênio amoniacal máxima medida aplicada no sistema chegou à $435 \mathrm{mgN}-\mathrm{NH}_{4}{ }^{+} \cdot l^{-1}$. Essa sobrecarga nitrogenada coincidiu com a mudança de condição do reator sulfetogênio, no qual foi quase triplicada a carga de sulfato a ser tratado e consequentemente tripicou-se a concentração de $\mathrm{N}$-amoniacal afluente. Tentou-se recuperar o sistema durante 15 dias, sem sucesso, e por esse motivo, optou-se pela reinoculação.

Nesta nova etapa, utilizou-se como estratégia de operação um ciclo total de 12 horas, compostas por duas fases: uma fase aerada e outra fase anóxica respectivamente, com duração de 6 horas cada. Reduziu-se também a concentração de biomassa para 5,8 $\mathrm{mgSVT} . l^{-1}$ (redução de aproximadamente $40 \%$ da biomassa suspensa presente no sistema).

Após a adaptação do lodo de inóculo nestas novas condições, foram realizados ensaios para determinação da melhor vazão de ar aplicado ao sistema nitrificante/desnitrificante. O afluente adicionado no sistema foi alcalinizado com bicarbonato de sódio $\left(\mathrm{NaHCO}_{3}\right)$ para que o processo nitrificante não se limitasse por alcalinidade. $\mathrm{Na}$ fase desnitrificante, foi adicionado parte do efluente do reator sulfetogênico e metanogênico, ricos em compostos reduzidos como ácidos orgânicos e sulfeto, para facilitar o processo desnitrificante.

Operou-se o sistema de biomassa suspensa nesta etapa durante 127 dias. De acordo com os dados de monitoramento, a carga nitrogenada aplicada no sistema com biomassa suspensa nesta Etapa 2 chegou à $0,61 \mathrm{kgN}-\mathrm{NH}_{4}{ }^{+} \cdot \mathrm{m}^{-3} \cdot \mathrm{dia}^{-1}$, com eficiência média de nitrificação de aproximadamente $85 \pm 12 \%$ no final da fase aeróbia, alcançando em muitos casos eficiência máxima de nitrificação de quase $100 \%$. Aproximadamente $98 \%$ do produto da nitrificação se deu à nitrito nesta etapa. A concentração média afluente de $\mathrm{N}$-amoniacal foi de $232 \pm 67 \mathrm{mgN} \mathrm{NH}_{4}{ }^{+} \cdot l^{-1}$ e a remoção média efetiva (remoção do meio líquido) de nitrogênio na fase desnitrificante foi de aproximadamente $42 \pm 21 \%$ em 6 horas e só se completou no tempo entre 12 e 15 horas. A concentração de sulfato no sistema foi de $724 \pm 90 \mathrm{mgSO}_{4}{ }^{-2} \cdot l^{-1}$; a concentração de sulfeto média foi de $154 \pm 136 \mu g \mathrm{SS}^{2-} . l^{-1}$ e não foi identificada a presença de sulfito no sistema. 


\subsubsection{Ajuste da aeração para o processo nitrificante}

Como a biomassa foi diminuída em aproximadamente $40 \%$ em relação à Etapa 1 inicial e o período de aeração foi diminuído, fez-se necessária a adequação da vazão de ar para favorecer a nitrificação, visando a otimização do sistema. Foram utilizadas 3 faixas de vazões de ar injetados no sistema: 2 a 3, 3 a 4 e 5 a 6 litros por minuto.

\subsubsection{ETAPA 2-Vazão de ar utilizada: 2 a 3 L.min $^{-1}$}

Para a realização deste experimento, foi utilizado o efluente do reator metanogênio. Não foi identificada a presença de ácidos durante todo o experimento. Nesta nova condição utilizou-se a concentração de biomassa média de 5,8 gSVT. $l^{-1}$. Verificou-se, neste caso, que a aeração (vazão de ar entre 2 e 3 L. min $^{-1}$ ) não foi suficiente para nitrificar no tempo desejado, conforme visto na Figura 31. Esperou-se nitrificar em 6 horas e para tanto foi necessário ajustar a aeração para que a oxidação de nitrogênio amoniacal fosse completa em tempo hábil.

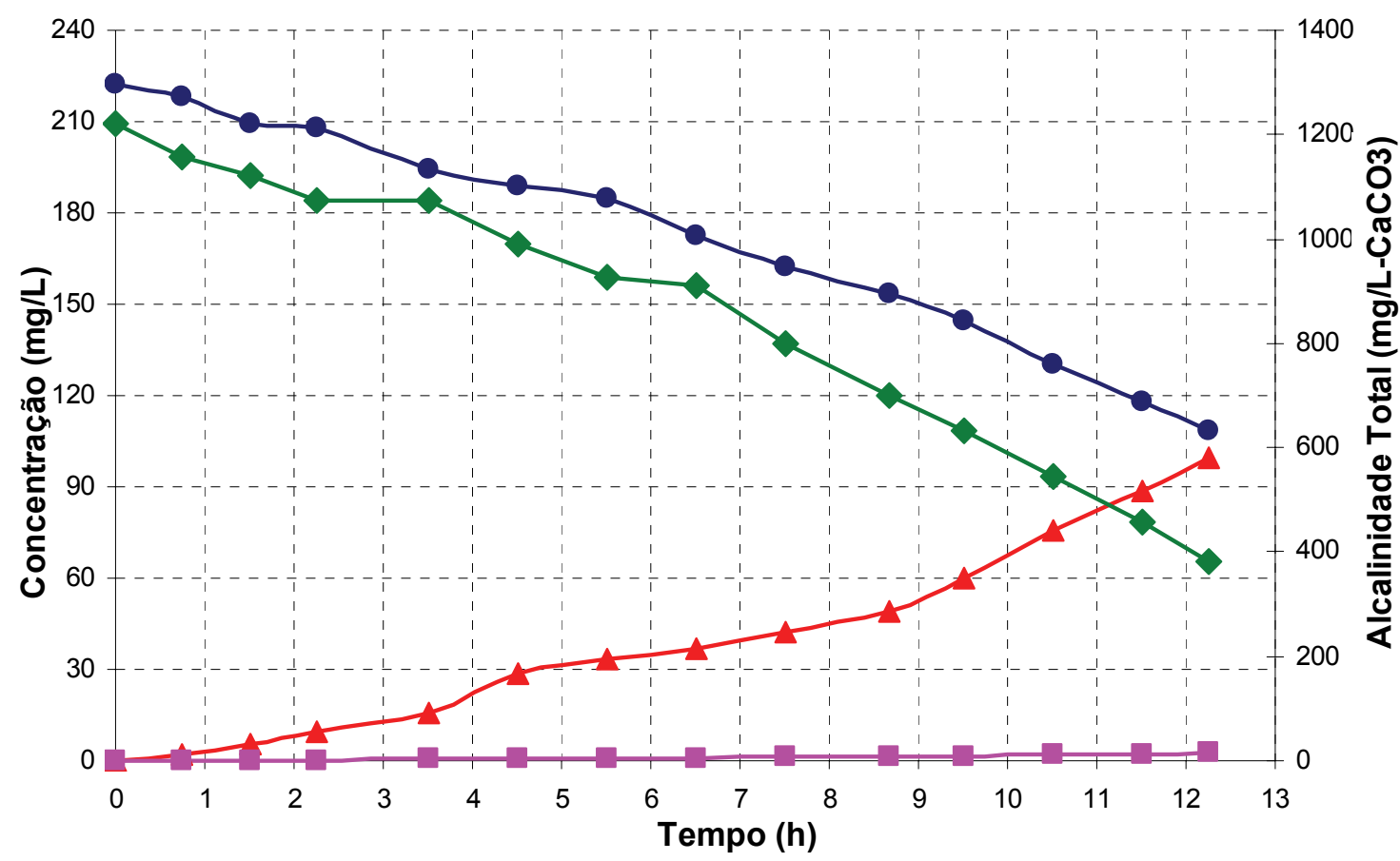

Figura 31: Ajuste da aeração para o processo nitrificante na Etapa 2. Vazão de ar utilizada de 2 a 3 L.min ${ }^{-1}$. NAmoniacal $(\bullet)$, N-Nitrato $(\square)$, N-Nitrito $(\boldsymbol{\Delta})$ e Alcalinidade Total $(\diamond)$.

Observa-se ainda na Figura 31, que houve um acúmulo de nitrito nesta etapa e a concentração de nitrato foi insignificante. Nota-se também que o decaimento do nitrogênio amoniacal foi acompanhado, com comportamento semelhante, ao decaimento da alcalinidade 
total (coeficiente de correlação de 0,998), indicando ser parâmetro de fácil e rápida análise para o monitoramento do nitrogênio amoniacal do sistema.

Tabela 9: Coeficientes cinéticos obtidos pelo modelo convencional de remoção de nitrogênio aplicado à ETAPA 2 no ajuste de aeração - Vazão de ar utilizada: 2 a 3 L.min ${ }^{-1}$.

\begin{tabular}{|c|c|c|c|c|c|c|c|}
\hline & & Unidade & Aeróbio 1 & & & & \\
\hline$\div$ & $\mathrm{k} 1{ }^{\prime}$ & $\mathrm{mg} \cdot \mathrm{l}^{-1} \cdot \mathrm{h}^{-1}$ & 7,929145 & $\mathrm{NH}_{3}$ & $\mathrm{NO}_{2}{ }^{-}$ & $\mathrm{k} 4$ & $\mathbf{N}_{2}$ \\
\hline$\frac{\mathscr{v}}{8}$ & k2' & $\mathrm{mg} \cdot \mathrm{l}^{-1} \cdot \mathrm{h}^{-1}$ & 0,165769 & & & & \\
\hline$\Sigma$ & k3 & $\mathrm{mg} \cdot \mathrm{l}^{-1} \cdot \mathrm{h}^{-1}$ & 0,012352 & & $\div 1$ & & \\
\hline & $\mathrm{k} 4$ & $\mathrm{~h}^{-1}$ & 0,020153 & & $\mathrm{NO}_{3}{ }^{-}$ & & \\
\hline
\end{tabular}

Observa-se na Tabela 9, que o coeficiente k1' foi muito maior do que k2' (k1' >> k2'), ou seja, houve o acúmulo de nitrito, pois a nitritação ocorreu numa velocidade muito superior (aproximadamente 50 vezes) do que a nitratação.

Apesar do constante fornecimento de oxigênio no sistema, verifica-se uma pequena atividade desnitrificante nesta fase aeróbia. Houve a ocorrência de uma pequena redução de nitrato a nitrito $\left(\mathrm{k} 3=0,012352 \mathrm{mg} \cdot l^{-1} \cdot \mathrm{h}^{-1}\right)$ e a redução de nitrito à nitrogênio gasoso $(\mathrm{k} 4=$ $\left.0,020153 \mathrm{~h}^{-1}\right)$. Isto se deve, provavelmente, a baixa aeração no sistema (2 a $3 \mathrm{~L} \cdot \mathrm{min}^{-1}$ ) e ao surgimento de zonas que favoreçem a desnitrificação devido à gradientes de oxigênio no interior do biofilme.

\subsubsection{ETAPA 2-Vazão de ar utilizada: 3 a 4 L.min $^{-1}$}

Utilizou-se para este experimento o efluente do reator metanogênico. Não foi identificada a presença de ácidos voláteis. Nota-se na Figura 32 que houve o acúmulo de nitrito e a concentração de nitrato foi muito baixa (máximo de $2,78 \mathrm{mg} . l^{-1}$ de N-Nitrato), porém o tempo para oxidação de todo nitrogênio amoniacal, ou a vazão de ar (3 a 4 L.min $\left.{ }^{-1}\right)$ para a biomassa presente não foram suficientes. Foi necessário, portanto, aumentar a vazão de ar, pois se desejou nitrificar em até 6 horas. 


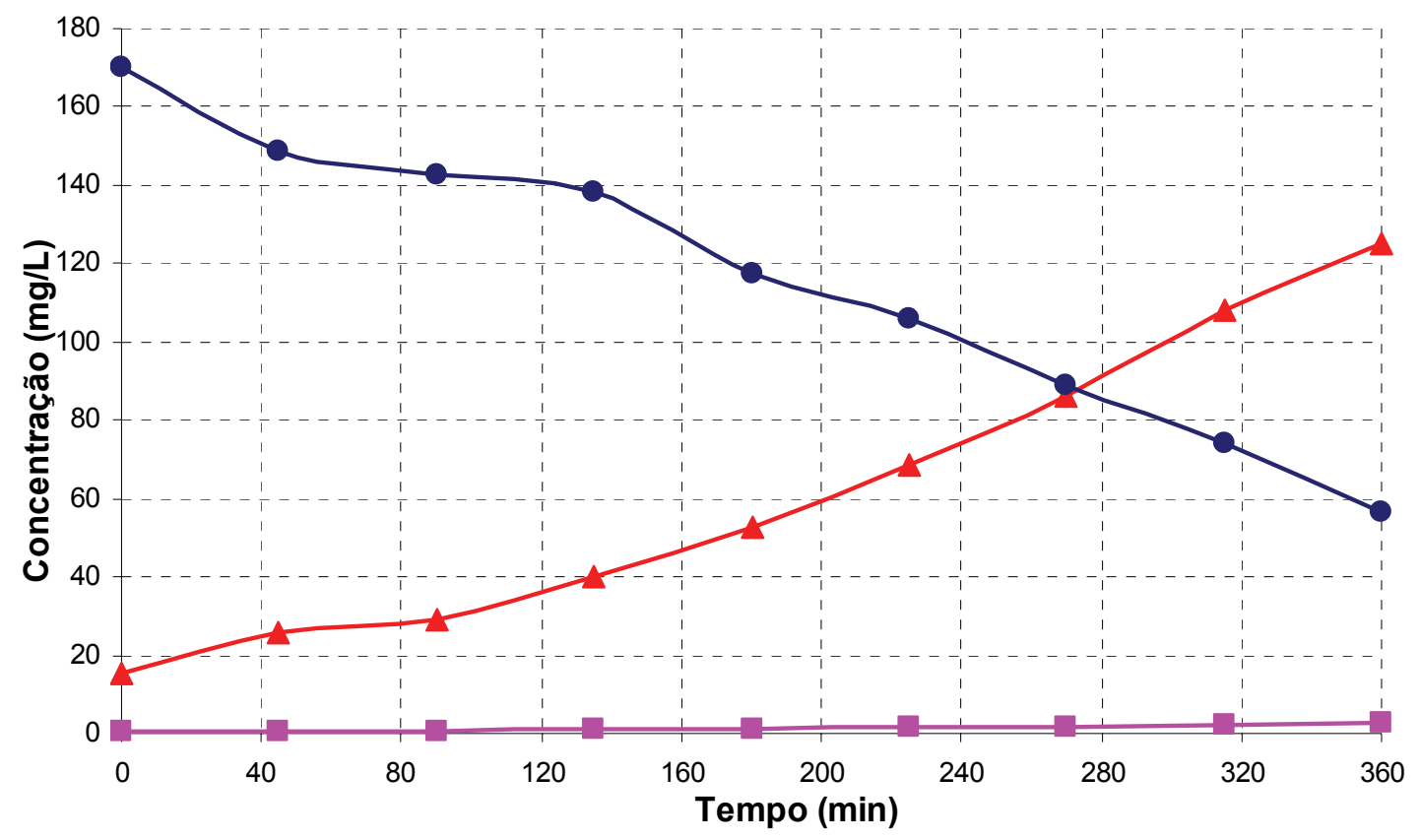

Figura 32: Ajuste da aeração para o processo nitrificante na Etapa 2. Vazão de ar utilizada de 3 a 4 L.min ${ }^{-1}$.N-

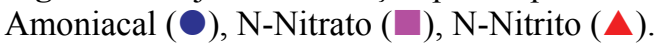

Tabela 10: Coeficientes cinéticos obtidos pelo modelo convencional de remoção de nitrogênio aplicado à ETAPA 2 no ajuste de aeração - Vazão de ar utilizada: 3 a 4 L.min ${ }^{-1}$.

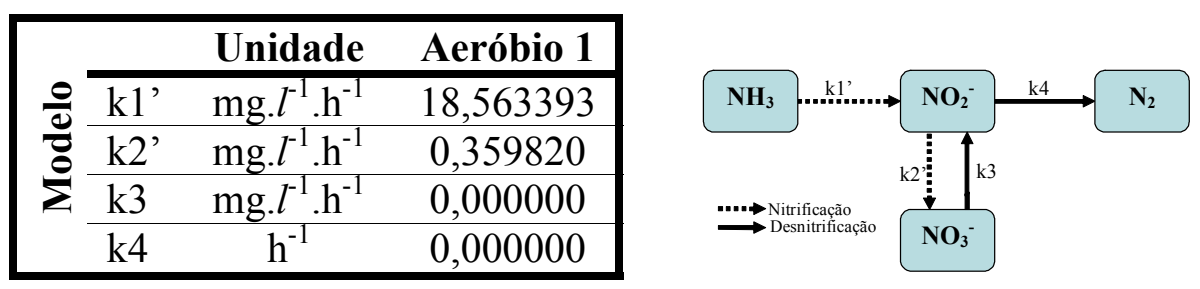

Observa-se na Tabela 10, que o coeficiente k1' foi muito maior do que k2' (k1' >> k2'), ou seja, houve o acúmulo de nitrito, pois a nitritação ocorreu numa velocidade muito superior (aproximadamente 50 vezes) do que a nitratação.

Nesta fase aeróbia, foi utilizada uma vazão de ar de 3 a 4 L. $\min ^{-1}$ (50\% superior ao experimento mostrado na Figura 31) e não foi identificada a ocorrência da redução de compostos nitrogenados.

\subsubsection{ETAPA 2-Vazão de ar utilizada: 5 a 6 L.mim $^{-1}$}

Utilizou-se para este experimento uma vazão de ar entre 5 e 6 litros por minuto. Verifica-se na Figura 33 que, a partir do tempo 5 horas, a concentração de nitrogênio amoniacal e a concentração de nitrito se mantiveram constantes. A nitrificação, neste caso, 
limitou-se à alcalinidade total no sistema, sendo esta zerada no tempo 5 horas, coincidente com a estabilização do nitrito e $\mathrm{N}$-amoniacal.

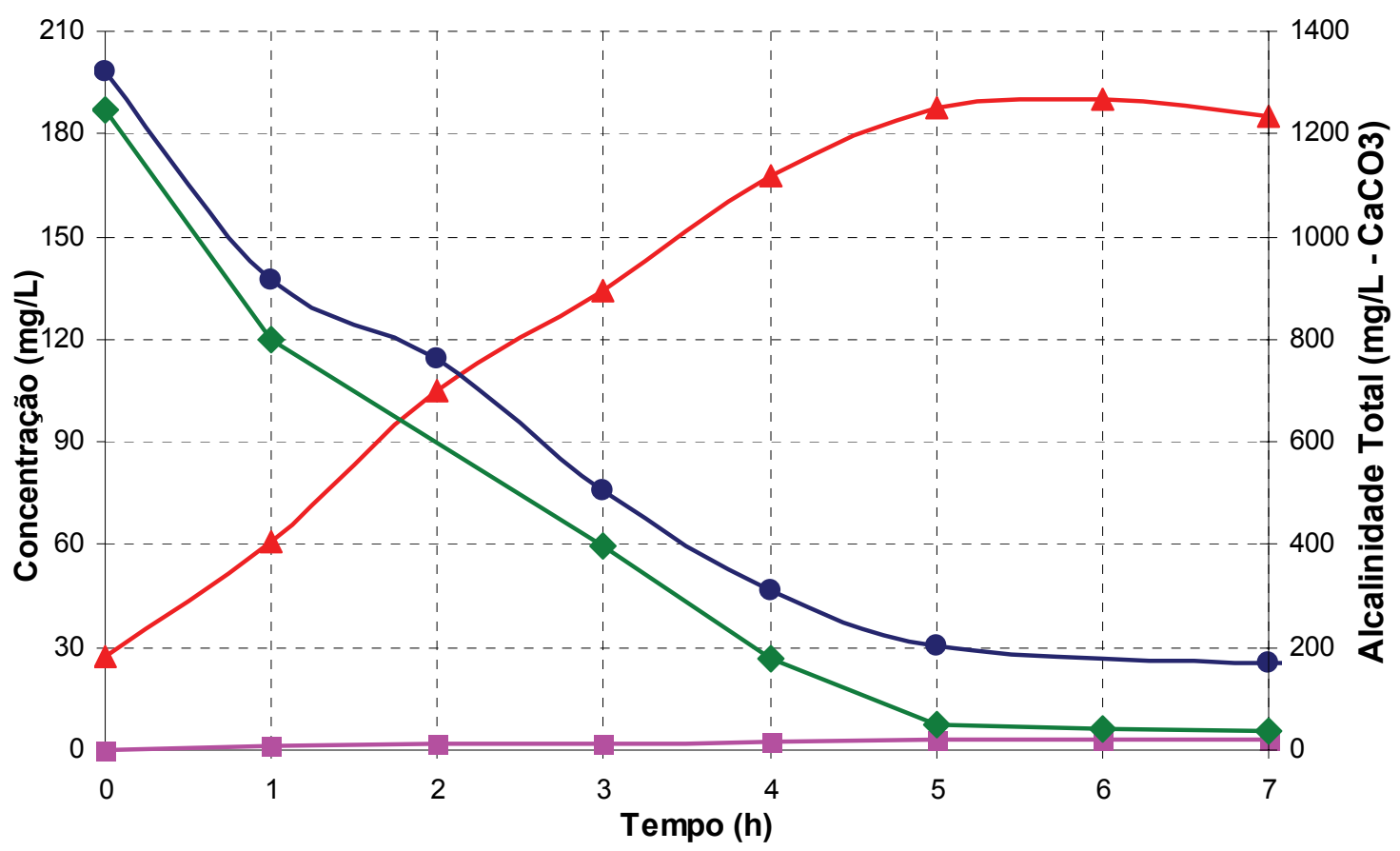

Figura 33: Ajuste da aeração para o processo nitrificante na Etapa 2. Vazão de ar utilizada de 5 a 6 L.min ${ }^{-1}$.NAmoniacal (○), N-Nitrato $(\square)$, N-Nitrito $(\Delta)$ e Alcalinidade Total $(\diamond)$.

A vazão de ar usada mostrou-se favorável para a nitrificação total até o tempo de 6 horas. Portanto, utilizou-se esta vazão para nitrificar, atentando-se para adicionar alcalinidade, de preferência em excesso para não limitar a nitrificação.

Tabela 11: Coeficientes cinéticos obtidos pelo modelo convencional de remoção de nitrogênio aplicado à ETAPA 2 no ajuste de aeração - Vazão de ar utilizada: 5 a 6 L.min ${ }^{-1}$.

\begin{tabular}{|cccc|}
\hline & & Unidade & Aeróbio 1 \\
\cline { 2 - 4 } & $\mathrm{k}{ }^{\prime}$ & $\mathrm{mg} \cdot l^{-1} \cdot \mathrm{h}^{-1}$ & 32,772405 \\
\hline & $\mathrm{k} 2$ & $\mathrm{mg} \cdot l^{-1} \cdot \mathrm{h}^{-1}$ & 0,668285 \\
\hline $\mathrm{k} 2$ & $\mathrm{mg} \cdot l^{-1} \cdot \mathrm{h}^{-1}$ & 0,000000 \\
\hline $\mathrm{k} 3$ & $\mathrm{~h}^{-1}$ & 0,000000 \\
\hline
\end{tabular}

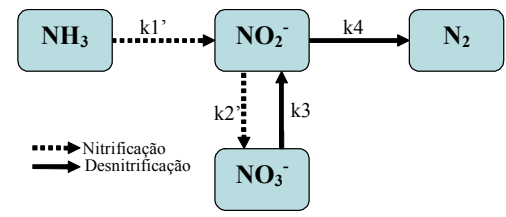

Observa-se na Tabela 11 que o produto principal da nitrificação foi o nitrito, pois a nitritação (convesão de nitrogênio amoniacal), denotado pelo coeficiente k1' foi aproximadamente 50 vezes superior à nitratação, representada pelo coeficiente k2'. Observa- 
se também, que os coeficientes k3 e k4 foram nulos, ou seja, não foi identificada a ocorrência do processo desnitrificante.

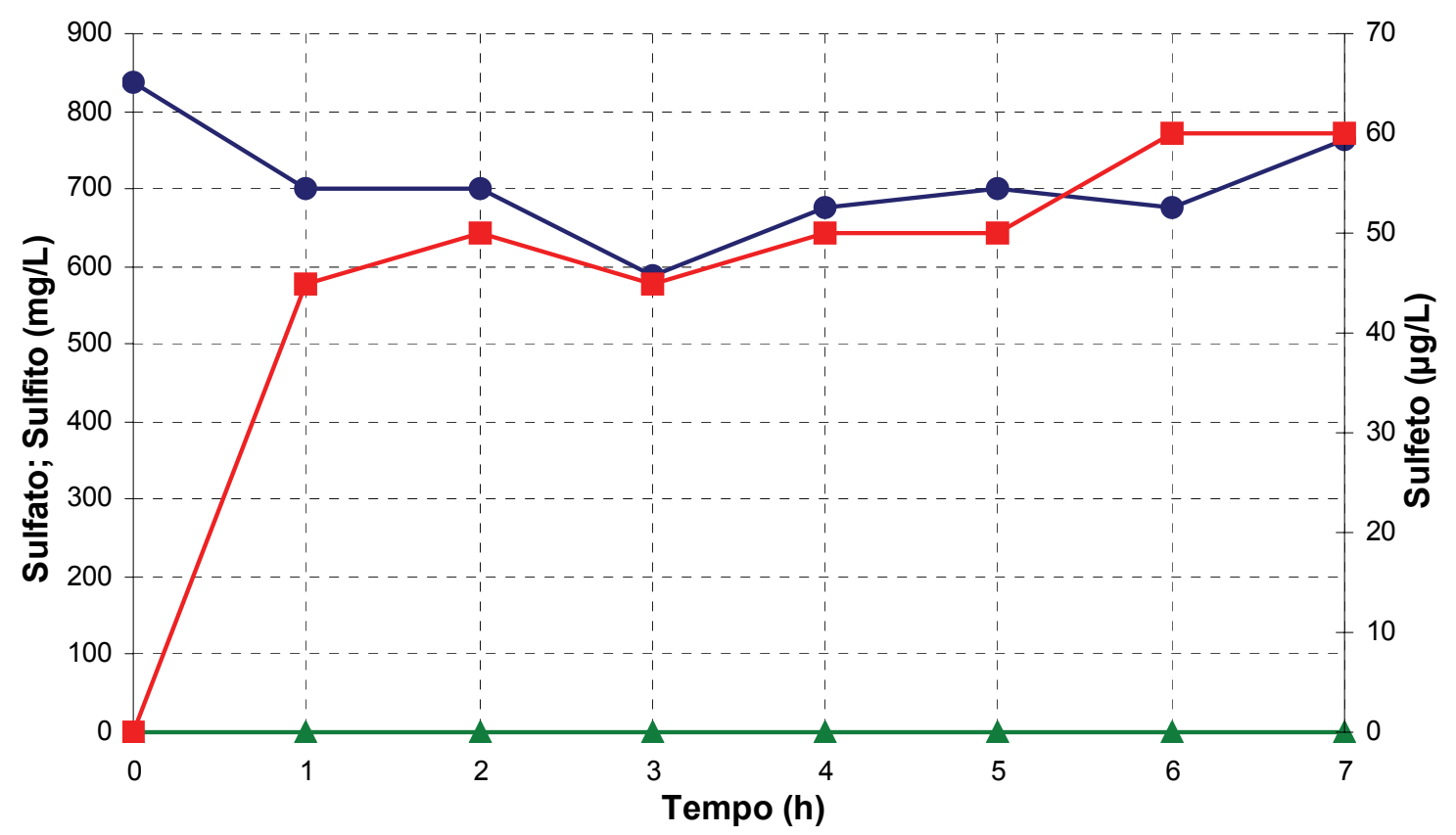

Figura 34: Perfil temporal de compostos de enxofre realizado conjuntamente com o ajuste da aeração para o

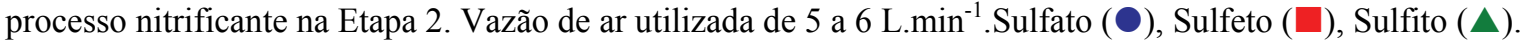

De acordo com a Figura 34, a concentração de sulfato presente no afluente era elevada, mantendo-se praticamente constante durante a fase nitrificante. Não foi notada interferência do sulfato na nitrificação. Apesar da condição aeróbia, manteve-se uma pequena concentração de sulfeto, aproximadamente $50 \mu \mathrm{g} . l^{-1}$, observando até uma certa tendência de aumento deste composto reduzido. Não foi identificada a presença de sulfito neste experimento.

\subsubsection{Verificação da desnitrificação}

Na Etapa 1 foi verificada a possibilidade de ocorrência da desnitrificação endógena. Nesta Etapa 2, com intuito de apurar a desnitrificação heterotrófica (utilizando compostos orgânicos) e a possível desnitrificação autotrófica (utilizando compostos inorgânicos) foi adicionada, na fase anóxica, uma parcela do afluente proveniente de reator metanogênico e sulfetogênico. $\mathrm{O}$ efluente destes dois reatores contém elevadas concentrações de compostos reduzidos que poderiam favorecer o processo de desnitrificação biológica. 


\subsubsection{ETAPA 2 -Adição de afluente na fase anóxica proveniente de reator metanogênico}

Para a realização deste ensaio, adicionou-se $600 \mathrm{~mL}$ de afluente preveniente de reator metanogênico na fase anóxica do experimento, para avaliação da desnitrificação. De acordo com a Figura 35, nesta fase desnitrificante, a concentração de $\mathrm{N}$-amoniacal não se alterou signficativamente. $\mathrm{O}$ decaimento de $\mathrm{N}$-amoniacal foi de aproximadamente $7,5 \mathrm{mg} \cdot \mathrm{l}^{-1}$. Observa-se que o produto principal da nitrificação da fase aeróbia anterior foi nitrito e a concentração de nitrato foi desprezível. Verifica-se que o tempo para remover o nitrito não foi suficiente.

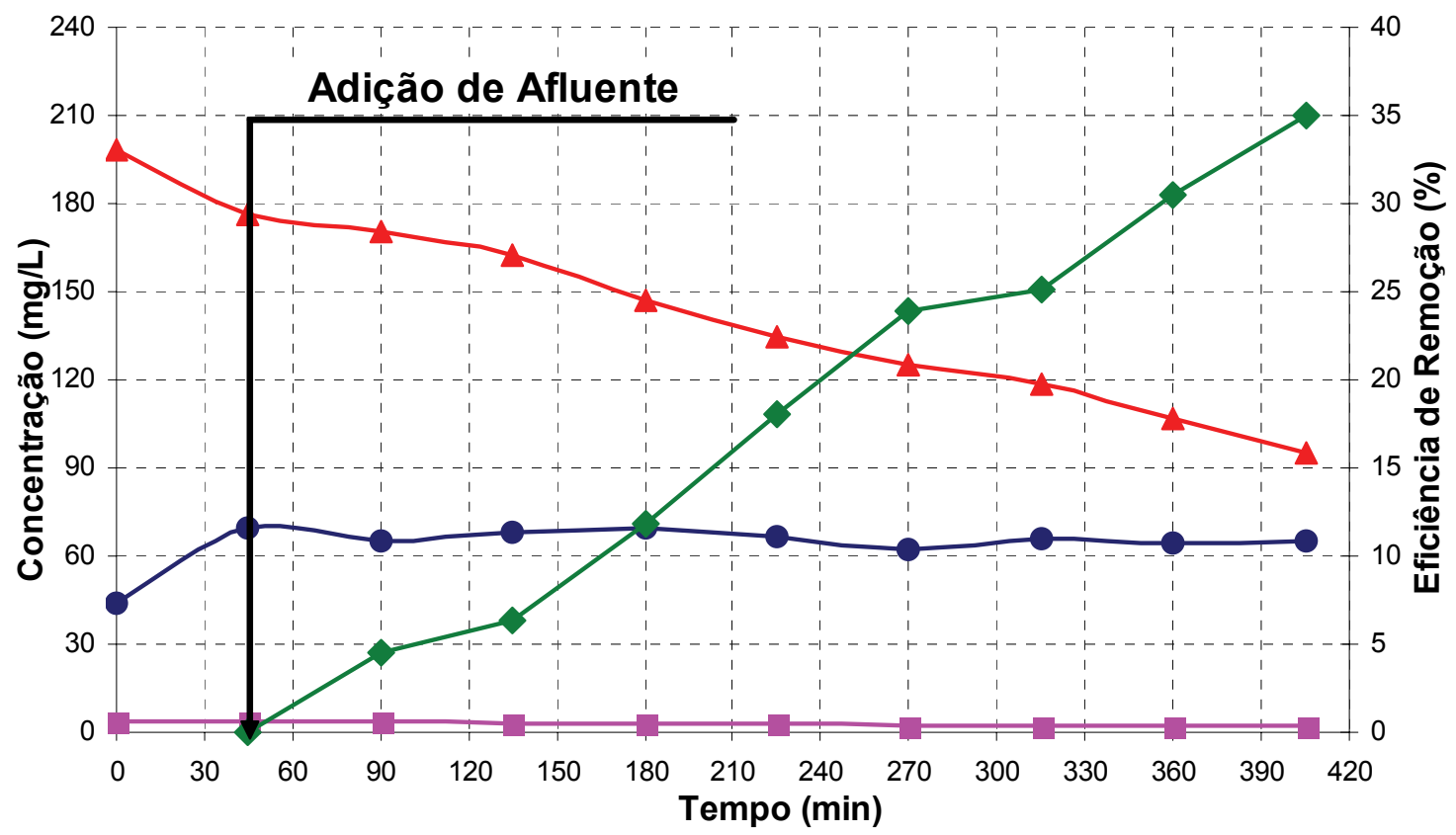

Figura 35: Verficação da desnitrificação na Etapa 2 com adição de afluente na fase anóxica proveniente de reator metanogênico. N-Amoniacal $(\mathbf{O})$, Nitrato $(\square)$, Nitrito $(\Delta)$ e Eficiência de Remoção de Nitrogênio $(\bullet)$.

Observa-se na Figura 38 que no tempo de 360 minutos, os ácidos foram completamente consumidos e, no entanto, o nitrito foi consumido após esse período podendo indicar a desnitrificação endógena.

Tabela 12: Coeficientes cinéticos obtidos pelo modelo convencional de remoção de nitrogênio aplicado à ETAPA 2 na fase desnitrificante, com adição de afluente proveniente de reator metanogênico.

\begin{tabular}{|c|c|c|c|}
\hline \multirow{5}{*}{$\frac{\frac{0}{0}}{\frac{0}{0}}$} & & Unidade & Aeróbio 1 \\
\hline & k1' & $\mathrm{mg} \cdot \mathrm{l}^{-1} \cdot \mathrm{h}^{-1}$ & 0,647817 \\
\hline & $\mathrm{k} 2$ ' & $\mathrm{mg} \cdot l^{-1} \cdot \mathrm{h}^{-1}$ & 0,000000 \\
\hline & k3 & $\mathrm{mg} \cdot l^{-1} \cdot \mathrm{h}^{-1}$ & 0,264098 \\
\hline & $\mathrm{k} 4$ & $h^{-1}$ & 0,097545 \\
\hline
\end{tabular}

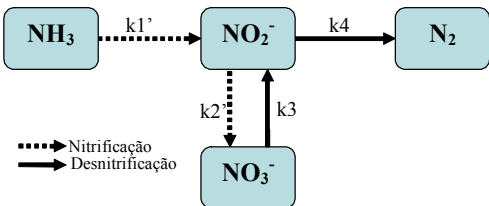


Verifica-se na Tabela 12, que nesta fase anóxica está ocorrendo a desnitrificação endógena, evidenciada pelo coeficiente k4. Observa-se também que houve a redução de nitrato à nitrito $\left(\mathrm{k} 3=0,264098 \mathrm{mg} \cdot l^{-1} \cdot \mathrm{h}^{-1}\right)$.

O coeficiente cinético de ordem zero k2' foi igual a zero, ou seja, não foi identificada a oxidação de nitrito a nitrato, como esperado em fase anóxica, na ausência de oxigênio. No entanto, observa-se que o coeficiente k1' foi diferente de zero. Este fato é bastante inusitado.

Um exame mais crítico do coeficiente $\mathrm{k} 1$ ' do modelo simplificado adotado remete à observância da ocorrência da oxidação do nitrogênio amoniacal na fase anóxica, mais conhecido como o fenômeno da ANAMMOX. Propõe-se, portanto, além do modelo de nitrificação e desnitrificação convencional, a aplicação de um modelo que englobe também a possibilidade de ocorrência da ANAMMOX, quando, em fase anóxica, k1' e k2' forem diferentes de zero.

Pode ser também que, além do processo ANAMMOX, esteja ocorrendo outro processo não convencional para remoção do nitrogênio, como o SURAMOX, porém atribuiuse essa remoção "inesperada" apenas ao fenômeno ANAMMOX, como discutido no item 4.6.4 deste mesmo capítulo (Comentários Gerais).

Na Figura 36 está o esquema do modelo proposto. Os coeficientes cinéticos k1' de nitritação, k2' de nitratação são coeficientes aparentes de ordem zero, pois dependem da concentração de oxigênio dissolvido no sistema e se relacionam também pela presença ou ausência de ácidos voláteis no sistema. O coeficiente k3 é um coeficiente de ordem zero e o coeficiente cinético k4 é um coeficiente de primeira ordem com dependência da concentração de N-nitrito. Os coeficientes k1', k2', k3' e k4' são idênticos ao modelo convencional para remoção de nitrogênio (Figura 22). Para determinação da ordem do coeficiente k5, realizou-se testes, variando-se à ordem deste coeficiente até obter um ajuste satisfatório. $\mathrm{O}$ coeficiente $\mathrm{k} 5$, de primeira ordem, tem dependência da concentração de N-amoniacal e representa a oxidação anaeróbia da amônia, mais conhecido como ANAMMOX. As equações do modelo cinético proposto podem ser observadas nas Equações 16 a 18. 


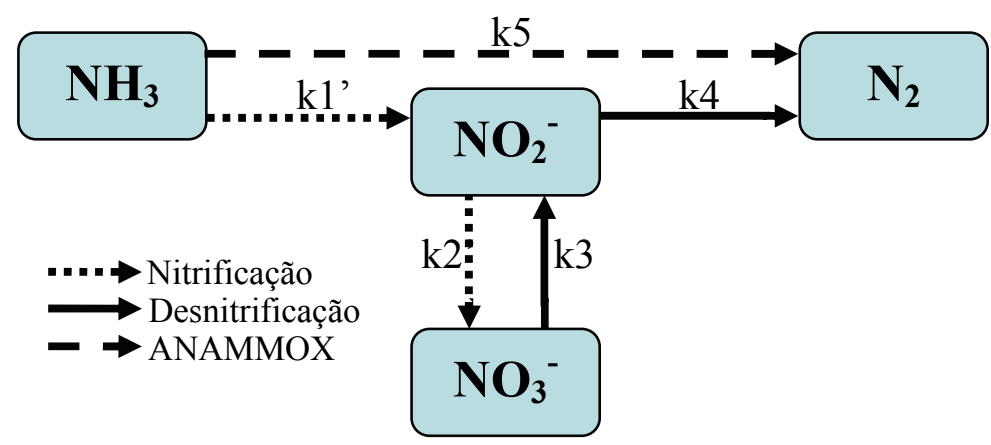

Figura 36: Esquema do modelo cinético adotado englobando a possibilidade de ocorrência da ANAMMOX.

$\frac{\partial\left[N H_{3}\right]}{\partial t}=-k_{1}{ }^{\prime}-k_{5} \cdot\left[N H_{4}^{+}\right]$

$\frac{\partial\left[N O_{2}^{-}\right]}{\partial t}=+k_{1}^{\prime}-k_{2}{ }^{\prime}+k_{3}-k_{4} \cdot\left[N O_{2}^{-}\right]$

$\frac{\partial\left[\mathrm{NO}_{3}^{-}\right]}{\partial t}=+k_{2}{ }^{\prime}-k_{3}$

O modelo da Figura 36 foi resolvido identicamente e tem as mesmas limitações e considerações do modelo convencional (Figura 22). Este modelo, chamado aqui de ANAMMOX, é um modelo complementar e será aplicado em casos excepcionais, quando:

- Em fase anóxica, no modelo convencional, os coeficientes de nitrificação k1' e k2' forem diferentes de zero;

- For detectada no sistema a presença de nitrogênio amoniacal;

- For detectada a presença de nitrito no sistema.

Tabela 13: Coeficientes cinéticos obtidos pelo modelo não-convencional de remoção de nitrogênio aplicado à ETAPA 2 na fase desnitrificante, com adição de afluente proveniente de reator metanogênico.

\begin{tabular}{|lll|}
\hline & Unidade & Anóxico \\
\cline { 2 - 3 } $\mathrm{k}{ }^{\prime}$ & $\mathrm{mg} \cdot l^{-1} \cdot \mathrm{h}^{-1}$ & 0,000000 \\
\hline $\mathrm{k} 2$ & $\mathrm{mg} \cdot l^{-1} \cdot \mathrm{h}^{-1}$ & 0,000000 \\
\hline $\mathrm{k} 3$ & $\mathrm{mg} \cdot l^{-1} \cdot \mathrm{h}^{-1}$ & 0,264122 \\
\hline $\mathrm{k} 4$ & $\mathrm{~h}^{-1}$ & 0,093029 \\
\hline $\mathrm{k} 5$ & $\mathrm{~h}^{-1}$ & 0,010142 \\
\hline
\end{tabular}

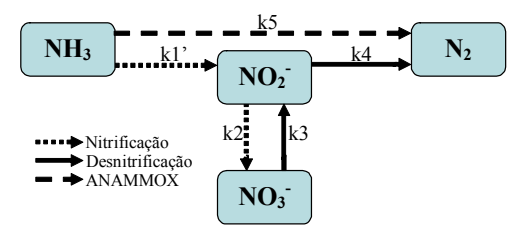


Observa-se na Tabela 13, os coeficientes otimizados do ajuste aos dados experimentais do modelo complementar ANAMMOX. Verifica-se que os coeficientes nitrificantes k1' e k2' foram nulos, ou seja, não foram identificadas as ocorrências da nitratação e da nitritação.

Nesta fase anóxica havia a redução, provavelmente dissimilativa, de nitrato a nitrito $\left(\mathrm{k} 3=0,264122 \mathrm{mg} \cdot l^{-1} \cdot \mathrm{h}^{-1}\right)$ e a desnitrificação heterotrófica $\left(\mathrm{k} 4=0,093029 \mathrm{~h}^{-1}\right)$.

Verifica-se que k5 foi diferente de zero, ou seja, foi identificada a presença da atividade ANAMMOX. Este coeficiente de primeira ordem k5 foi aproximadamente 9 vezes menor do que o coeficiente de desnitrificação convencional $\mathrm{k} 4$, portanto a atividade ANAMMOX presente no sistema foi muito tímida em relação à atividade desnitrificante convencional.

Esses dados do modelo que engloba o processo ANAMMOX da Tabela 13 estão mais coerentes do que os dados do modelo convencional, mostrados na Tabela 12, pois teoricamente, seria impossível obter a nitrificação em fase anóxica, ou seja, os coeficientes cinéticos $\mathrm{k} 2$ ' e principalmente $\mathrm{k} 1$ ' obrigatoriamente teriam que ser nulos ou muito próximos de zero, em fase anóxica.

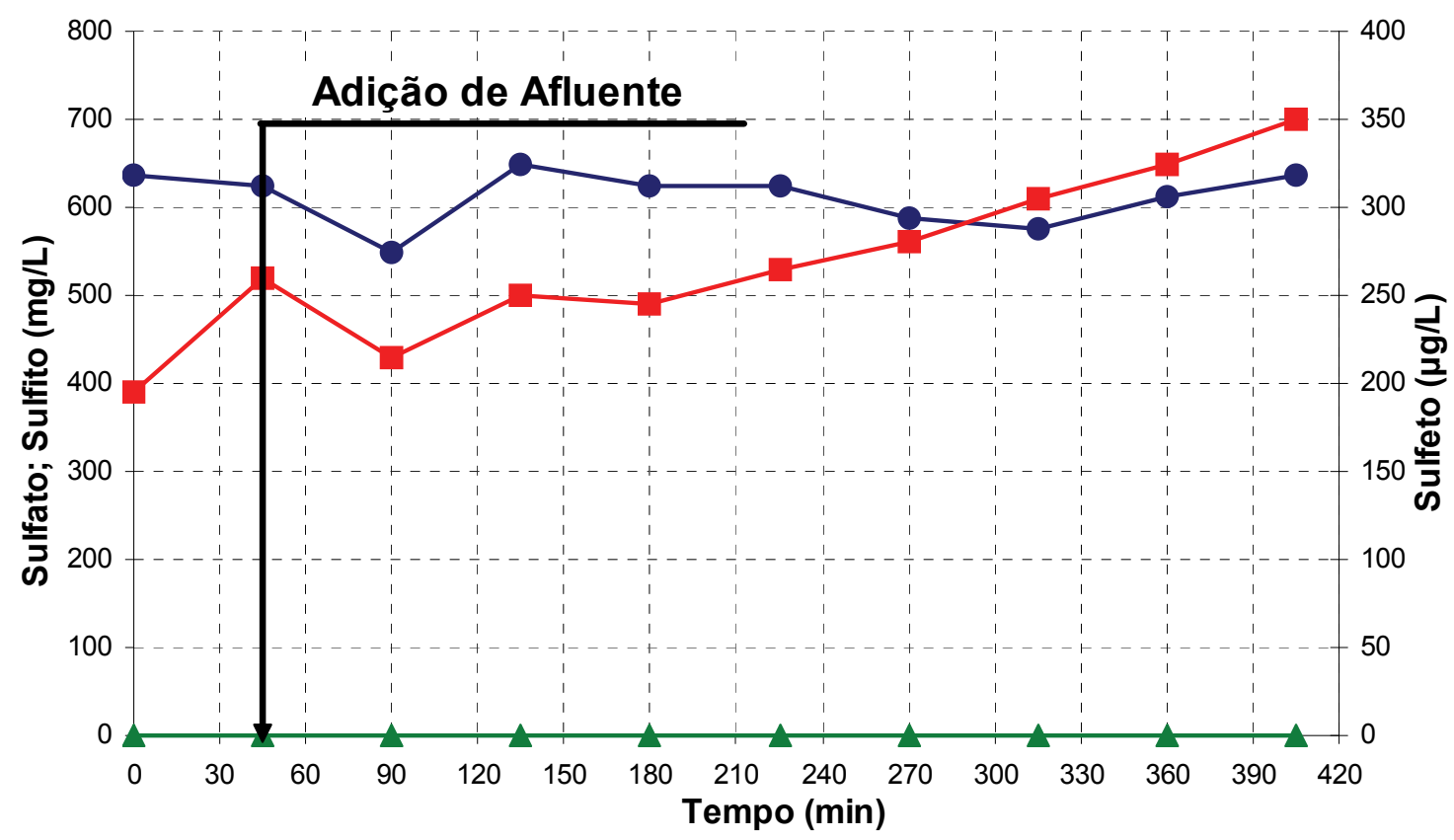

Figura 37: Acompanhamento dos compostos de enxofre na fase anóxica da Etapa 2 com adição de afluente proveniente de reator metanogênico. Sulfato $(\mathbf{O})$, Sulfeto $(\square)$, Sulfito $(\mathbf{\Delta})$ 
Não foi identificada a presença de sulfito em todo o perfil temporal de concentração e a concentração de sulfato permaneceu praticamente constante, como observado na Figura 37.

$\mathrm{O}$ aumento do sulfeto nesta fase anóxica indica que houve, conjuntamente com a redução de nitrito, a redução de sulfato. Uma hipótese interessante a ser levantada é que a desnitrificação endógena pode não ocorrer diretamente. Em águas residuárias ricas em sulfato, como neste caso, pode ter ocorrido a desnitrificação endógena "indireta", ou seja, em um primeiro momento a redução endógena de sulfato, produzindo sulfeto e a consequente desnitrificação autotrófica utilizando o sulfeto.

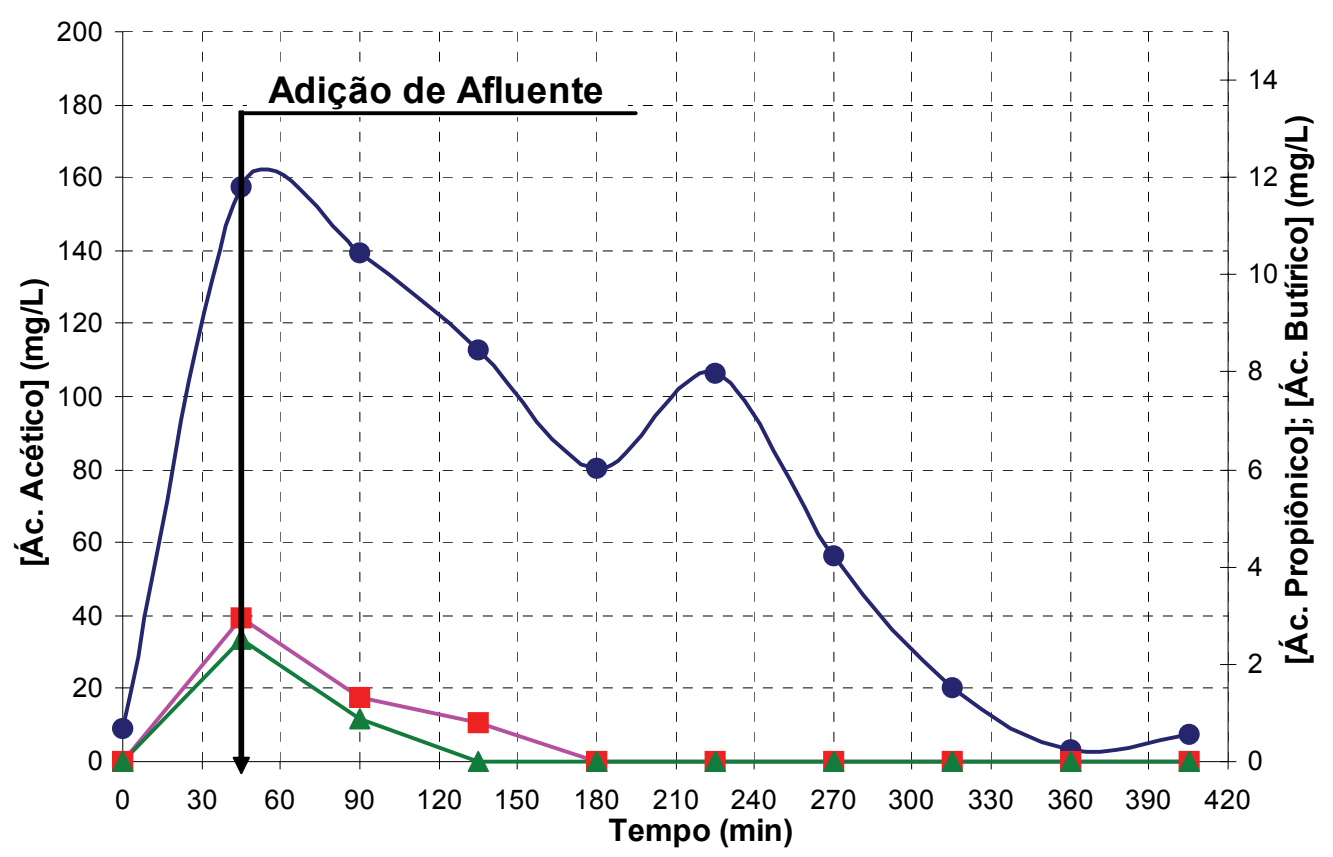

Figura 38: Acompanhamento de ácidos orgânicos na fase anóxica da Etapa 2 com adição de afluente

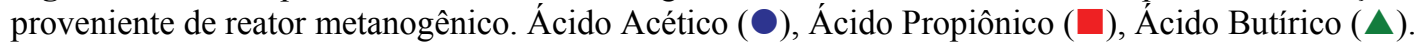

Verifica-se na Figura 38 que os ácidos, principalmente o ácido acético, foram vagarosamente consumidos, esgotando-se apenas no final do ciclo.

$\mathrm{O}$ afluente adicionado nesta fase foi originado do reator metanogênico. Observa-se uma baixa concentração de ácido acético (160 mg. $\left.l^{-1}\right)$ em comparação com o efluente do reator sulfetogênico, que chegava, em alguns casos, próximo de $1000 \mathrm{mg} . l^{-1}$ de ácido acético.

Algum distúrbio não identificado ocorreu entre os tempos 180 e 225 minutos, refletindo também no potencial de óxido redução (Figura 39), aumentando-o. O distúrbio coincidiu com o decrécimo do ácido propiônico, porém não se acredita que este tenha influenciado o distúbio ocorrido. 


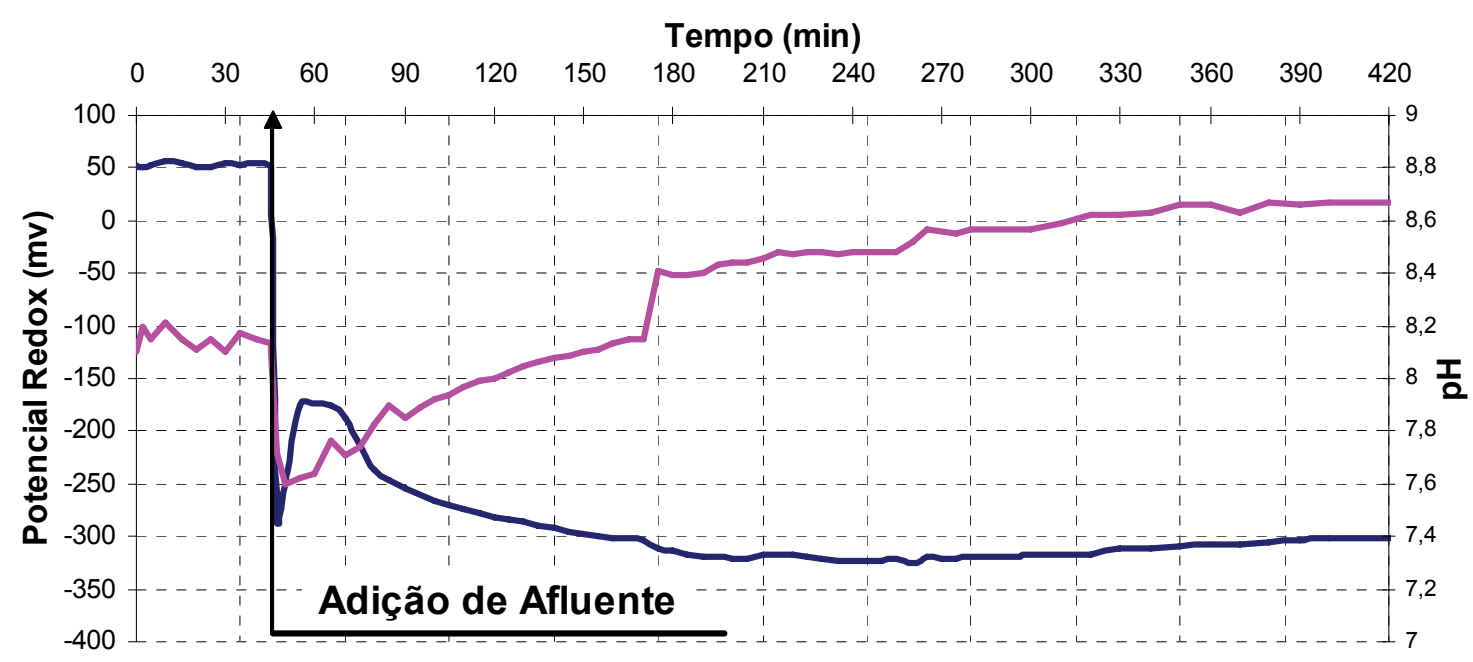

Figura 39: Acompanhamento do $\mathrm{pH}$ e do potencial Redoz na fase anóxica da Etapa 2 com adição de afluente proveniente de reator metanogênico.- - Potencial Redox, $-\mathrm{pH}$.

Observa-se na Figura 39 a queda brusca do pH e do potencial REDOX com a adição de afluente, pois este tem um $\mathrm{pH}$ baixo $(5,5)$ e um meio muito reduzido $(-350 \mathrm{mv})$.

Verficou-se uma tendência de aumento do potencial de óxido redução, provavelmente devido ao consumo de ácidos voláteis, que são compostos muito reduzidos. Após o tempo de 60 minutos, observou-se uma tendência de queda do $\mathrm{pH}$, ao contrário do que diz a literatura, pois a desnitrificação produz alcalinidade, elevando sensivelmente o $\mathrm{pH}$.

\subsubsection{ETAPA 2 - Adição de afluente na fase anóxica proveniente de reator sulfetogênico}

Adicionou-se para este experimento $500 \mathrm{ml}$ de afluente proveniente do reator sulfetogênico. Neste caso, não se sabe o motivo de não ter ocorrido a desnitrificação. Este foi um caso isolado. Verifica-se na Figura 40, que a concentração de nitrito não se alterou com o tempo, assim como a concentração de nitrogênio amoniacal. 


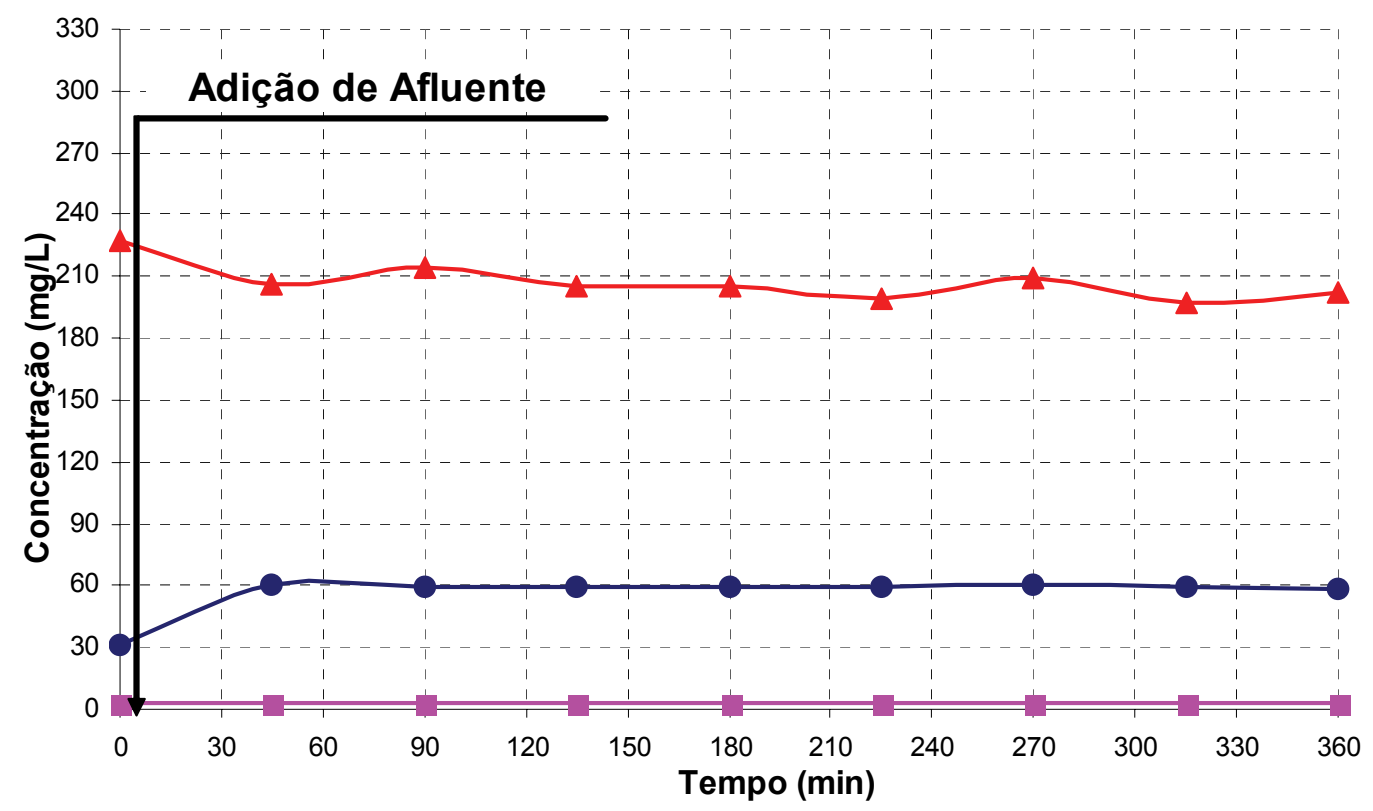

Figura 40: Verficação da desnitrificação na Etapa 2 com adição de afluente na fase anóxica proveniente de reator sulfetogênico. N-Amoniacal $(\mathbf{O})$, N-Nitrato $(\square)$, N-Nitrito $(\Delta)$.

Este pode ser um caso de toxicidade, lembrando que reatores de biomassa suspensa são mais susceptíveis à esses efeitos prejudiciais. O nitrito e o sulfeto podem ocasionar toxicidade em sistemas biológicos. Infelizmente, neste experimento não foram realizados ensaios da série de enxofre para poder aferir algo sobre a toxicidade causada pelo sulfeto. Observa-se uma alta concentração de nitrito $\left( \pm 200 \mathrm{mg} . \mathrm{l}^{-1}\right)$ e decaimento de $\mathrm{N}$-amoniacal de $2,4 \mathrm{mg} . l^{-1}$, muito baixo, provavelmente devido a assimilação por microrganismos.

Tabela 14: Coeficientes cinéticos obtidos pelo modelo convencional de remoção de nitrogênio aplicado à ETAPA 2 na fase desnitrificante, com adição de afluente proveniente de reator sulfetogênico.

\begin{tabular}{|c|c|c|c|c|c|c|}
\hline \multirow{5}{*}{$\frac{0}{\frac{0}{0}}$} & & Unidade & Aeróbio 1 & & & \multirow[b]{2}{*}{$\stackrel{\mathrm{k} 4}{\longrightarrow} \mathbf{N}_{2}$} \\
\hline & k1' & $\mathrm{mg} \cdot l^{-1} \cdot \mathrm{h}^{-1}$ & 0,162557 & \multirow{4}{*}{ 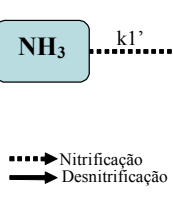 } & & \\
\hline & $\mathrm{k} 2{ }^{\prime}$ & $\mathrm{mg} \cdot \mathrm{l}^{-1} \cdot \mathrm{h}^{-1}$ & 0,000000 & & & \\
\hline & k3 & $\mathrm{mg} \cdot \mathrm{l}^{-1} \cdot \mathrm{h}^{-1}$ & 0,010322 & & $i 1$ & \\
\hline & $\mathrm{k} 4$ & $\mathrm{~h}^{-1}$ & 0,004720 & & $\mathrm{NO}_{3}{ }^{-}$ & \\
\hline
\end{tabular}

Observa-se nesta fase anóxica, pela Tabela 14, que houve-se uma baixa redução de nitrato à nitrito $\left(\mathrm{k} 3=0,010233 \mathrm{mg} \cdot \mathrm{l}^{-1} \cdot \mathrm{h}^{-1}\right)$ e uma baixa desnitrificação $\left(\mathrm{k} 4=0,004720 \mathrm{~h}^{-1}\right)$. 62 
Praticamente nada ocorreu com as concentrações de nitrato e nitrito. O coeficiente k2', que representa a oxidação de nitrito a nitrato foi igual a zero, como esperado, porém, verifica-se que o coeficiente cinético do modelo nitrificante/desnitrificante convencional k1', que indica a nitritação, foi diferente de zero, mas este fato é improvável que ocorra. Com base nesses dados, conclui-se que se pode aplicar o modelo que inclui o processo ANAMMOX, pois preenche todos os requisitos mínimos: em fase anóxica, quando o coeficiente k1' for diferente de zero e quando for detectada a presença de nitrito e nitrogênio amoniacal.

Tabela 15: Coeficientes cinéticos obtidos pelo modelo não-convencional de remoção de nitrogênio aplicado à ETAPA 2 na fase desnitrificante, com adição de afluente proveniente de reator sulfetogênico.

\begin{tabular}{|c|c|c|c|c|c|}
\hline$\not$ & & Unidade & $\begin{array}{l}\text { Anóxico } \\
\text { s/ Ácidos }\end{array}$ & & \\
\hline$\frac{}{0} \stackrel{0}{z}$ & $\mathrm{k} 1$ ' & $\mathrm{mg} \cdot l^{-1} \cdot \mathrm{h}^{-1}$ & 0,000000 & $\mathrm{NH}_{3} \ldots$ & $\stackrel{\mathrm{k} 4}{\longrightarrow} \stackrel{\mathrm{N}_{2}}{\longrightarrow}$ \\
\hline$\frac{\pi}{8}$ & $\mathrm{k} 2$ ' & $\mathrm{mg} \cdot l^{-1} \cdot \mathrm{h}^{-1}$ & 0,000000 & & \\
\hline$\sum \bar{z}$ & k3 & $\mathrm{mg} \cdot \mathrm{l}^{-1} \cdot \mathrm{h}^{-1}$ & 0,010306 & 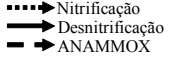 & $+\left.\right|^{503}$ \\
\hline 2 & $\mathrm{k} 4$ & $h^{-1}$ & 0,003926 & & $\mathrm{NO}_{3}^{-}$ \\
\hline & $\mathrm{k} 5$ & $\mathrm{~h}^{-1}$ & 0,002727 & & \\
\hline
\end{tabular}

Verifica-se na Tabela 15, que o coeficiente k3 foi muito semelhante ao da Tabela 14, ou seja, a redução de nitrato a nitrito no modelo convencional, não se alterou no modelo ANAMMOX. Os coeficientes $\mathrm{k} 1$ ' e k2' foram iguais a zero, significando que não houve a nitrificação. Esses dados são mais consistentes do que os apontados na Tabela 14 (modelo nitrificante/desnitrificante convencional), pois é improvável a ocorrência de processos oxidativos em fase anóxica .

Verifica-se pela Tabela 15, que $\mathrm{k} 5$ foi diferente de zero $\left(\mathrm{k} 5=0,002727 \mathrm{~h}^{-1}\right)$, ou seja, foi identificada a oxidação de nitrogênio amoniacal em fase anóxica (ANAMMOX). Este coeficiente de primeira ordem (k5) foi aproximadamente 30\% menor em comparação com o coeficiente de desnitrificação convencional $\mathrm{k} 4 \quad\left(0,003926 \mathrm{~h}^{-1}\right)$, porém a atividade desnitrificante e a atividade ANAMMOX foram muito reduzidas, quase imperceptíveis visualmente. 


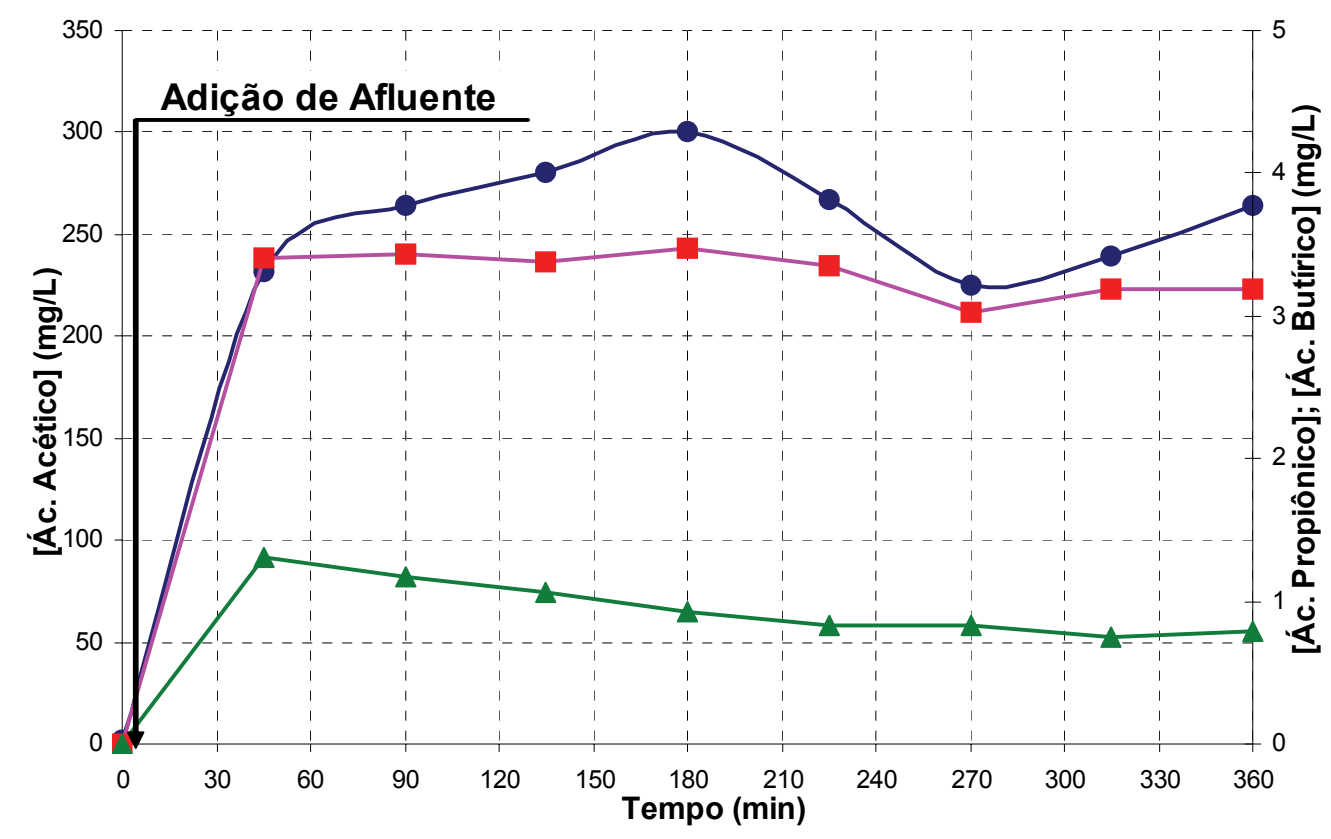

Figura 41: Acompanhamento de ácidos orgânicos na fase anóxica da Etapa 2 com adição de afluente

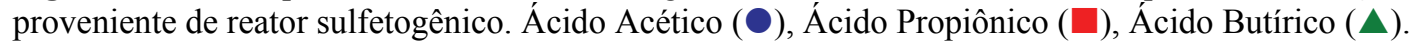

Observa-se na Figura 41, que havia ácidos disponíveis para a desnitrificação. Até o tempo 180 minutos, houve um acréscimo significativo de ácido acético (aproximadamente 50 mg. $l^{-1}$ ), provavelmente devido a hidrólise do lodo. Nos tempos entre 180 a 270 minutos verifica-se um decréscimo de $75 \mathrm{mg} . l^{-1}$ e um acréscimo posterior de aproximadamente 40 mg. $l^{-1}$ até o final do ciclo. Nota-se também, que houve uma tendência de decréscimo dos ácidos propiônicos e butírico, porém as concentrações destes no sistema foram muito reduzidas.

\subsubsection{Ensaio com Microsensor}

No sistema com biomassa suspensa (Etapa 2), verificou-se que o tempo médio de desnitrificação completa era próximo ou superior a 12 horas, tempo muito superior ao que se impôs inicialmente. Outro agravante é que o sistema foi muito sensível à compostos, que em determinada concentração ocasionaram toxicidade aos microrganismos, devido a facilidade de difusão nos flocos.

Outro problema deste reator é a sedimentação do lodo, ocasionando perda de biomassa significante que poderia afetar seriamente a nitrificação e a desnitrificação. 
Diante destes problemas apresentados no reator de biomassa suspensa na Etapa 2, pensou-se na possibilidade de minimizar os efeitos de toxicidade, diminuindo o fluxo difusivo de compostos tóxicos no biofilme.

Uma alternativa para esses problemas seria a utilização de biomassa imobilizada, porém, surgiram algumas dúvidas: Qual seria o melhor material suporte a escolher? Qual material suporte poderia favorecer o sistema nitrificante/desnitrificante?

Para elucidar estas e outras questões, utilizou-se técnica de microsensores para a avaliação do melhor meio suporte a utilizar neste caso específico. Com esses resultados, é possível vislumbrar também outras possibilidades, como a nitrificação e a desnitrificação simultâneas, em uma única etapa dentro do biofilme.

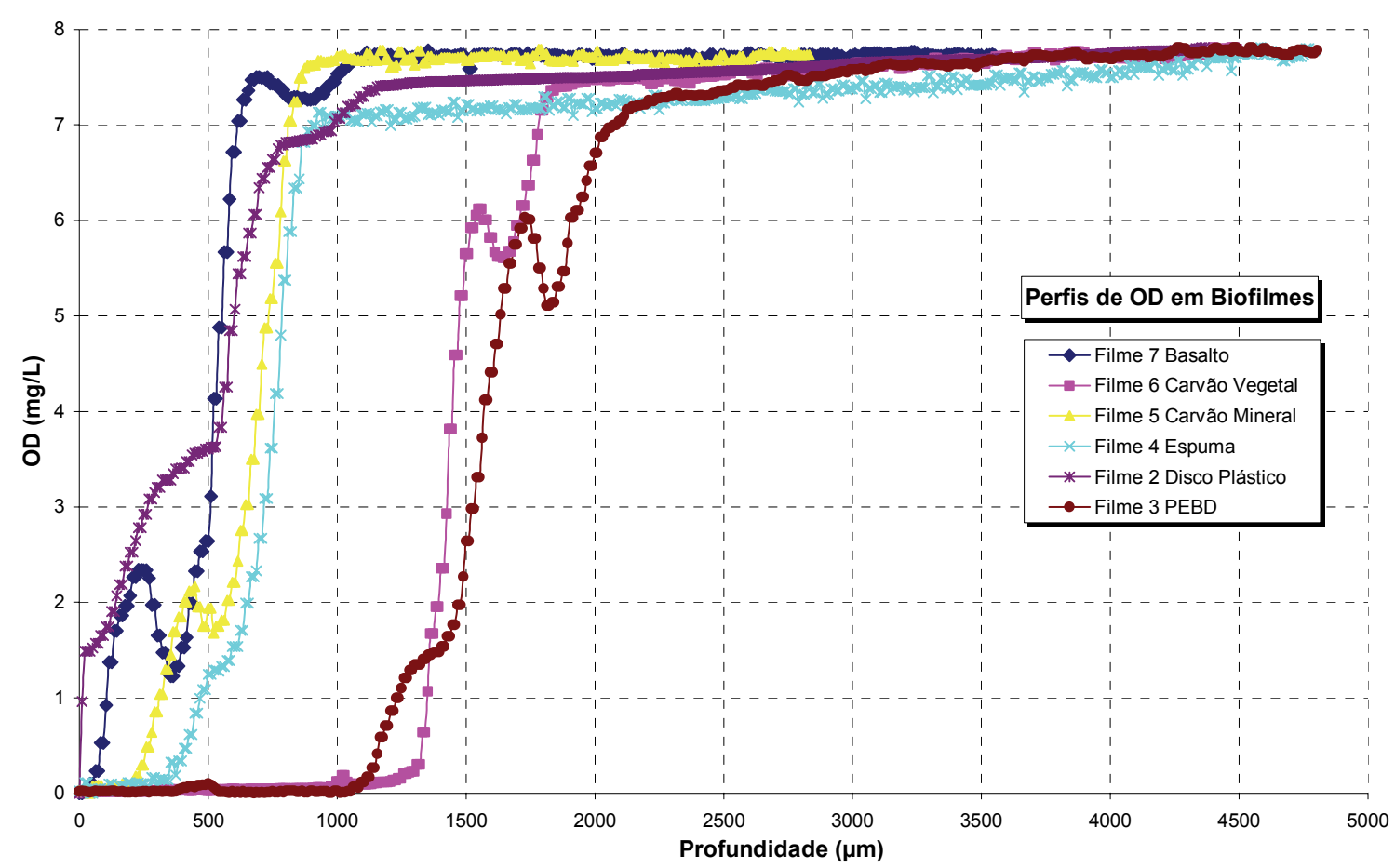

Figura 42: Resultados de diversos ensaios com microsensor em biofilmes. Relação da profundidade com a concentração de oxigênio dissolvido.

Neste experimento utilizou-se 6 tipos de materiais suportes diferentes: Brita basáltica; Carvão Vegetal; Carvão Mineral; Espuma de Poliuretano; Discos plástico; e Polietileno de Baixa Densidade, conforme mostrados nas Figura 43 a Figura 48 . Os perfis de concentração de oxigênio dissolvido no interior dos biofilmes estão compilados na Figura 42 e detalhados nas Figura 49 a Figura 52. 


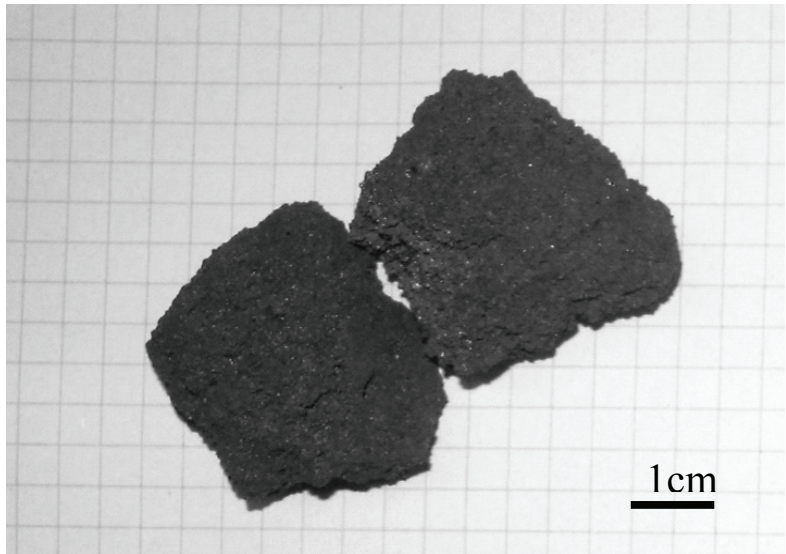

Figura 43: Foto do material suporte Carvão Mineral.

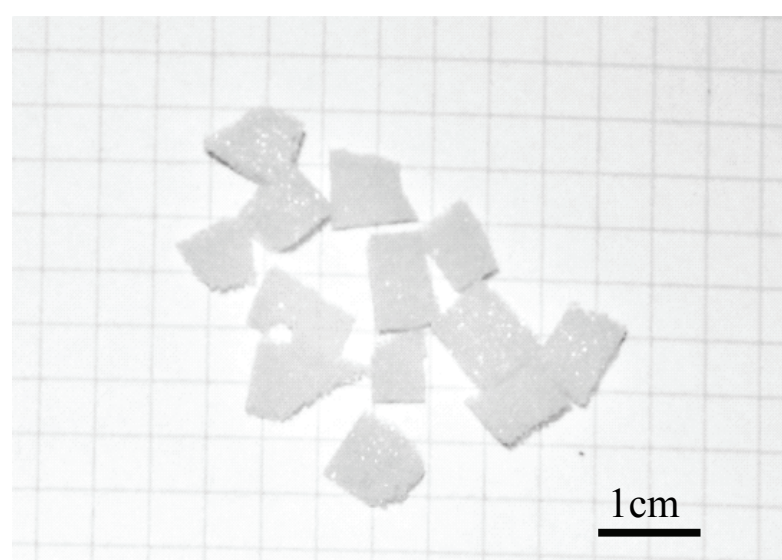

Figura 45: Foto do material suporte Espuma de Poliuretano.

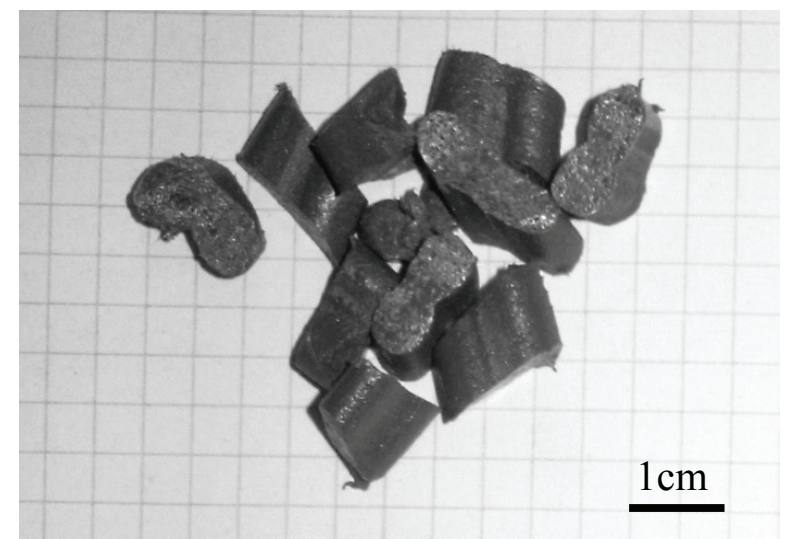

Figura 47: Foto do material suporte Polietileno de Baixa Densidade.

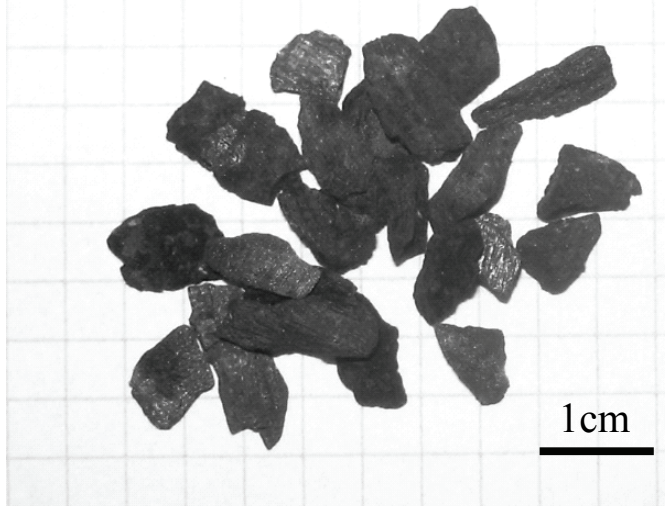

Figura 44: Foto do material suporte Carvão Vegetal.

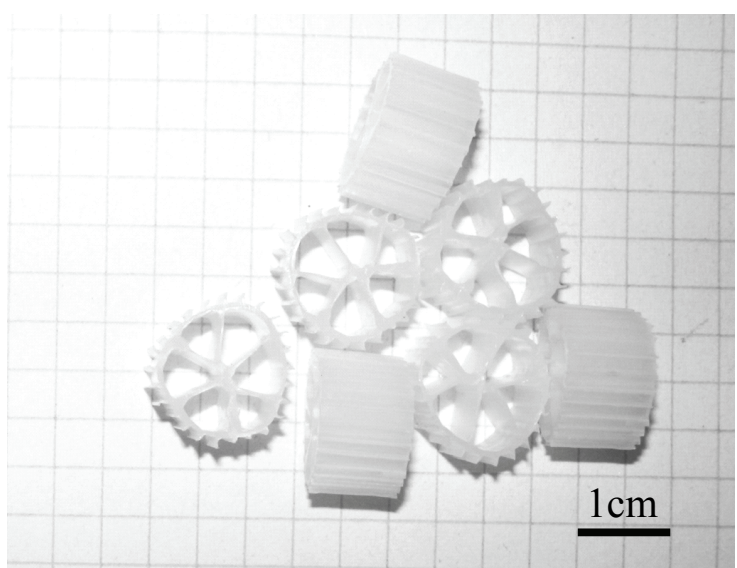

Figura 46: Foto do material suporte Discos Plásticos. (Polietileno)

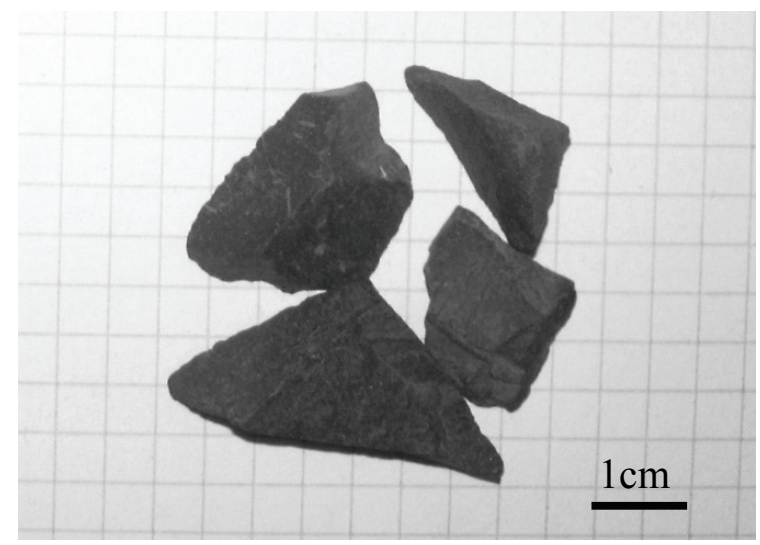

Figura 48: Foto do material suporte Brita Basáltica. 


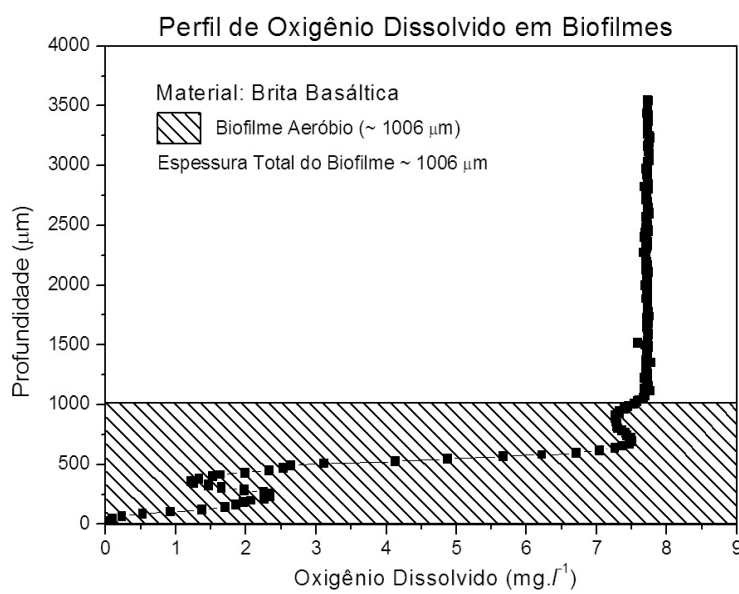

Figura 49: Perfil de oxigênio em biofilme. Material suporte - Brita Basáltica.

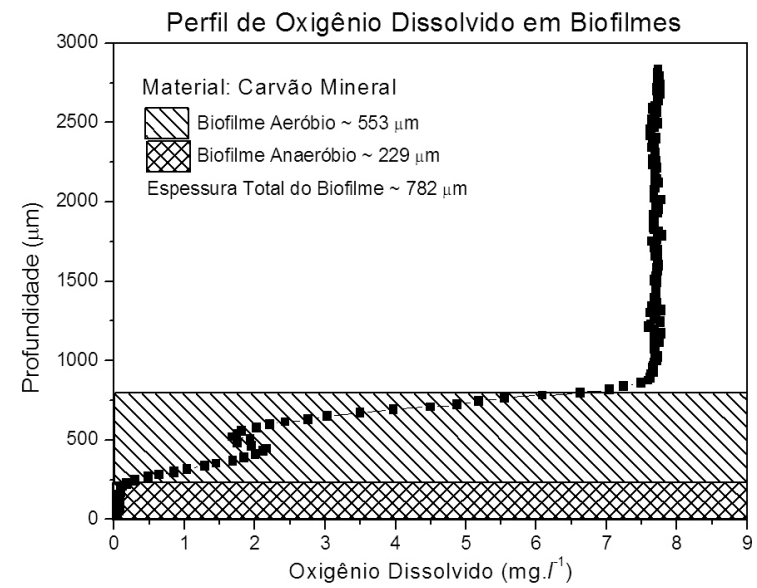

Figura 51: Perfil de oxigênio em biofilme. Material suporte - Carvão Vegetal.

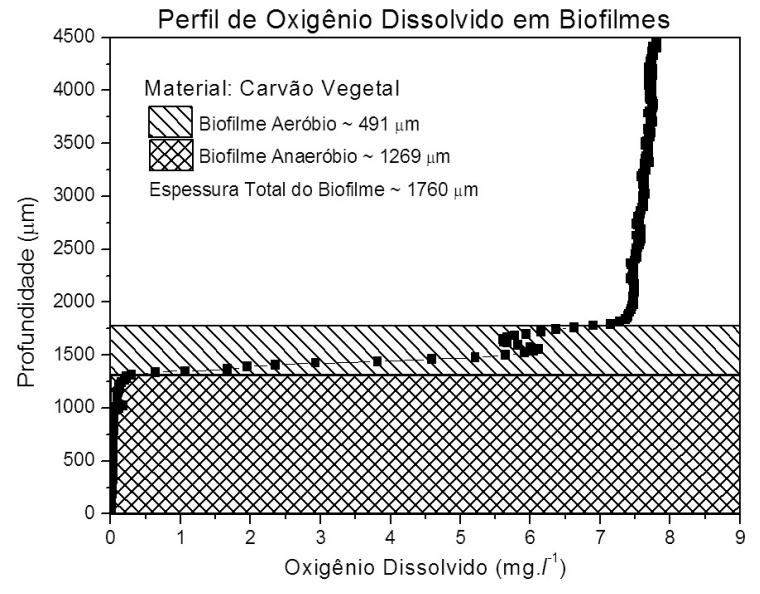

Figura 50: Perfil de oxigênio em biofilme. Material suporte - Carvão Mineral.

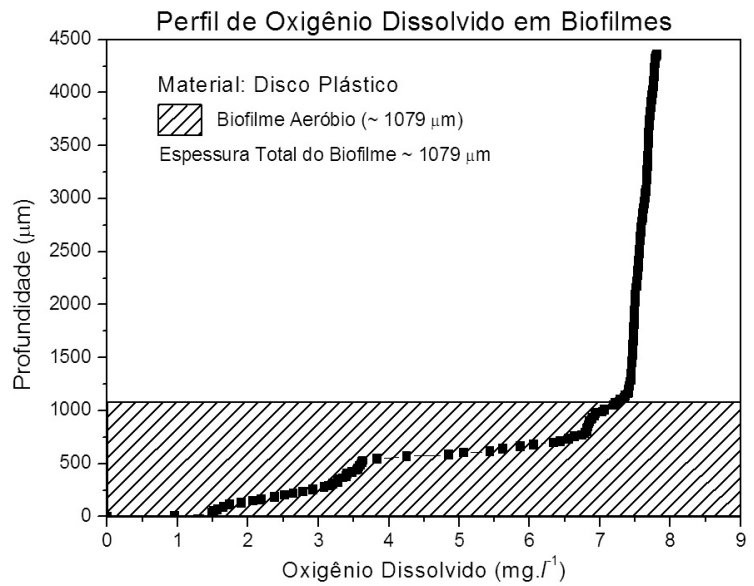

Figura 52: Perfil de oxigênio em biofilme. Material suporte-Disco Plástico.

Para se determinar o início do contato do microsensor no biofilme, tomou-se como base à pesquisa realizada por Lewandowski e colaboradores em 1991. Esses pesquisadores instrumentaram um microsensor para medição da concentração de oxigênio dissolvido com uma micro fibra-optica capilar. Sobrepondo os dois resultados obidos em seguidos e repetidos ensaios, os autores concluíram que o início do contato com o biofilme se dava no ponto de inflexão da curva de concentração com a profundidade. $\mathrm{O}$ biofilme anaeróbio foi determinado para concentração de oxigênio dissolvido menor do que $0,2 \mathrm{mgOD} \cdot I^{\mathbf{1}}$. 


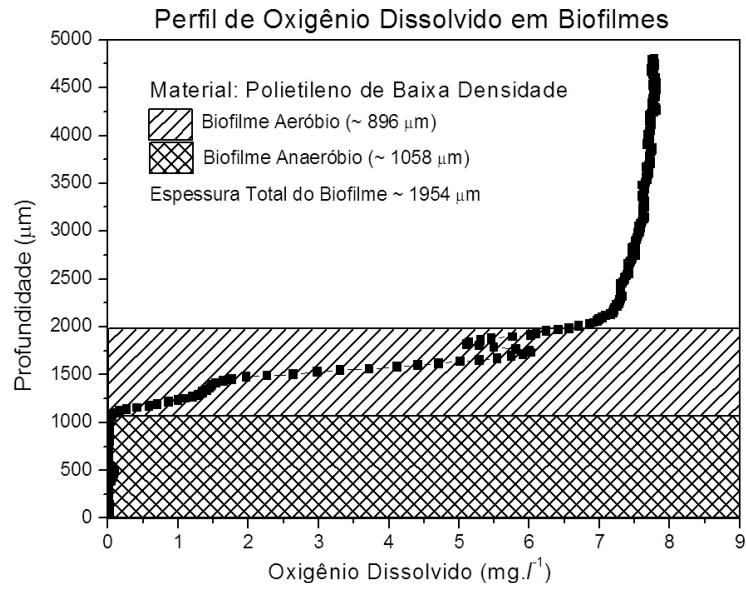

Figura 53: Perfil de oxigênio em biofilme. Material suporte -Polietileno de Baixa Densidade.

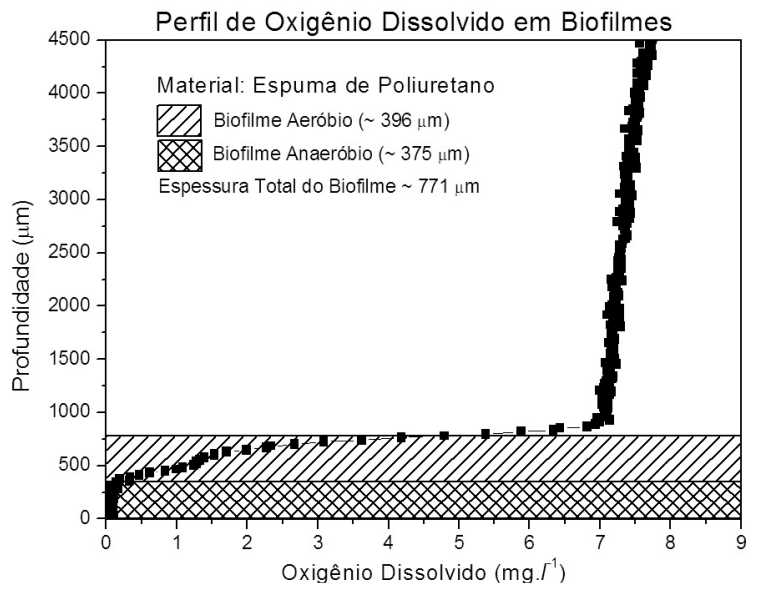

Figura 54: Perfil de oxigênio em biofilme. Material suporte-Espuma de Poliuretano.

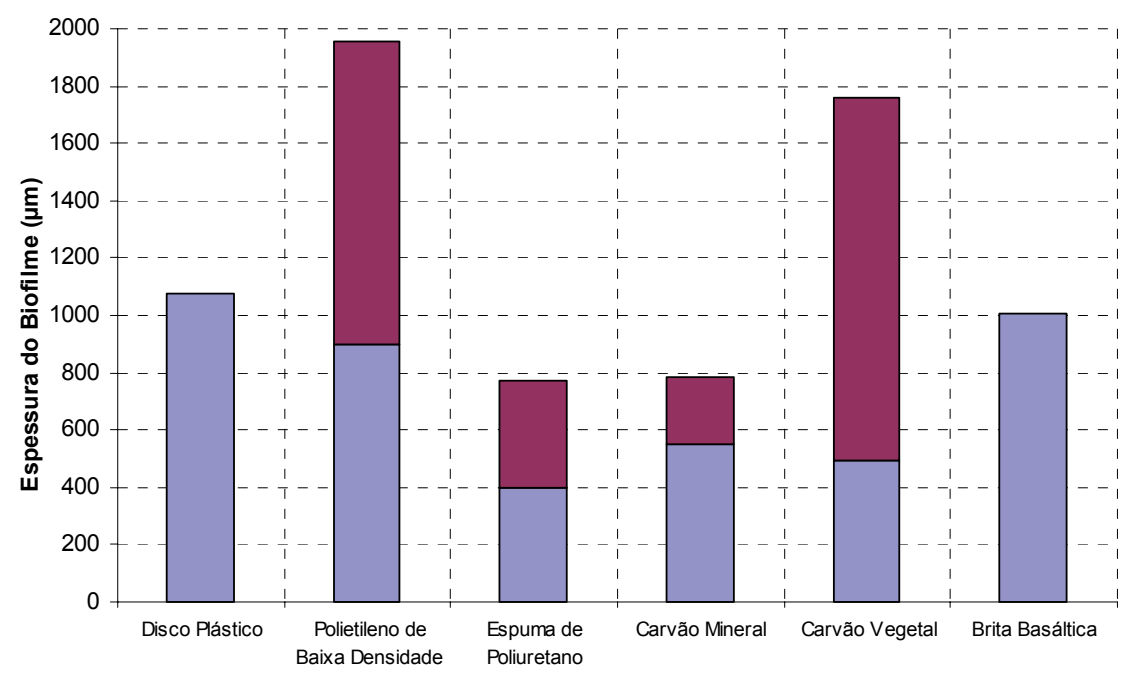

Figura 55: Comparação entre as espessuras dos biofilmes nos diferentes suportes: — Biofilme aeróbio e Biofilme Anóxico.

Escolheu-se como material suporte o carvão mineral tendo em vista que este material propiciou o surgimento de zonas aeróbias e anóxicas no mesmo biofilme, podendo, portanto, favorecer sua aplicação nos sistemas nitrificantes/desnitrificantes.

Segundo as Figuras 49 a 54 e Figura 55, não foram desenvolvidas zonas anóxicas nos biofilmes dos suportes "disco plástico" e "brita basáltica". O suporte "carvão vegetal" favoreceu um elevado desenvolvimento de biofilme aeróbio e principalmente anóxico. $\mathrm{O}$ suporte "polietileno de baixa densidade" também favoreceu um alto desenvolvimento microbiano aderido e espessuras dos biofilmes aeróbios e anóxicos foram semelhantes. A espessura dos biofilmes nos suportes "espuma de poliuretano" e "carvão mineral" foram 
muito semelhantes, porém bastante interiores aos dos suportes "polietileno de baixa densidade" e "carvão vegetal".

Como se trata de uma aplicação dos suportes inertes em reator nitrificante/desnitrificante, preocupou-se em determinar um suporte que favorecesse o desenvolvimento de biofilmes aeróbios e anóxicos e também em escolher um material suporte que não favorecesse excessivamente o crescimento microbiano, para não ocorrer a perda significativa do volume útil do reator, e conseqüentemente, a colmatação do leito. Tendo isto em vista, descartou-se, por conseguinte, os suportes "disco plástico" e "brita basáltica", por apresentarem apenas zonas aeróbias. Foram descartados também os suportes de "polietileno de baixa densidade" e "carvão vegetal", pois estes, apesar de apresentarem zonas aeróbias e anóxicas, tiveram um desenvolvimento microbiano bastante elevado.

Dentre os suportes "espuma de poliuretano" e "carvão mineral" optou-se pelo "carvão mineral", devido às propriedades mecânicas do suporte "espuma de poliuretano": desgaste à possíveis atritos internos e redução excessiva de volume na ausência de líquido devido ao achatamento do leito. Estes fatores poderiam propiciar a desagregação e prejudica a estrutura do biofilme e, conseqüentemente, prejudicar o desempenho do reator.

\subsection{ETAPA 3}

Nesta Etapa 3 utilizou-se reator com biomassa imobilizada, com a finalidade de comparar este novo sistema com o reator de biomassa suspensa utilizado na Etapa 2. Após realização de ensaios com microsensor, foi possível escolher o material suporte 'Carvão Mineral' para ser utilizado no reator nesta nova etapa, pois este era compatível com o sistema nitrificante/desnitrificante, por favorecer o desenvolvimento de zonas aeradas e não aeradas no interior do biofilme.

A operação do sistema com biomassa imobilizada desta Etapa 3 seguiu um padrão semelhante à operação do sistema de biomassa suspensa da Etapa 2. A batelada tinha duração de 12 horas, incluindo uma fase aeróbia com duração de 6 horas e fase anóxica com a mesma duração da fase anterior. Assim como na Etapa 2, foram adicionados na fase anóxica afluentes provenientes de reatores metanogênicos e sulfetogênico para acelerar o processo desnitrificante. Nesta etapa não foram realizados ensaios para ajuste da melhor vazão de ar a ser aplicado no sistema. Utilizou-se para a fase nitrificante a melhor vazão de ar encontrada na Etapa 2 (5 a 6 L.min $\left.{ }^{-1}\right)$. 
Operou-se o sistema de biomassa imobilizada nesta etapa durante 134 dias. De acordo com os dados do monitoramente, a carga nitrogenada aplicada no sistema com biomassa imobilizada nesta Etapa 3 chegou a $0,50 \mathrm{kgN}-\mathrm{NH}_{4}{ }^{+} \cdot \mathrm{m}^{-3} \cdot \mathrm{dia}^{-1}$, com eficiência média de nitrificação de $94 \pm 9 \%$ alcançando ao longo da operação valores próximos de $100 \%$ de eficiência do processo nitrificante em até 6 horas. O produto principal da nitrificação foi o nitrito e a concentração de nitrato não superou $5 \%$ em relação à concentração de nitrito (será discutido adiante neste mesmo capítulo no item 4.6 - Comentário Gerais). A concentração média afluente de $\mathrm{N}$-amoniacal foi de $177 \pm 31 \mathrm{mgN}^{-\mathrm{NH}_{4}}{ }^{+} \cdot l^{-1}$ e a remoção média efetiva (remoção do meio líquido) de nitrogênio na fase desnitrificante foi de aproximadamente $72 \pm 13 \%$ em, no máximo, 6 horas. Em muitos casos, obteve-se à remoção próximas de 100\% de nitrato e nitrio em tempo inferior a 6 horas. A concentração de sulfato no sistema foi de $325 \pm 33 \mathrm{mgSO}_{4}{ }^{-2} \cdot l^{-1}$; a concentração de sulfeto média no sistema foi de $498 \pm 729 \mu \mathrm{gS}^{2-} \cdot l^{-1}$ e a concentração de sulfito foi de $20 \pm 39 \mathrm{mgSO}_{3}{ }^{-2} \cdot l^{-1}$.

\subsubsection{Verificação da desnitrificação}

Como na Etapa 2 anterior, foi adicionada, após a fase aeróbia (fase nitrificante), na fase anóxica (fase desnitrificante), afluentes provenientes de reator sulfetogênico e metanogênico a fim de avaliar qual seria a melhor fonte de afluente a ser adicionado na fase desnitrificante.

\subsubsection{ETAPA 3 - Adição de afluente na fase anóxica proveniente de reator metanogênico}

Adicionou-se nesta fase desnitrificante $1500 \mathrm{~mL}$ de efluente do reator metanogênico. Observa-se na Figura 56 que a concentração de nitrito, proveniente da fase aeróbia anterior, foi predominante em relação à concentração de nitrato. Verifica-se uma pequena queda da concentração de $\mathrm{N}$-amoniacal (aproximadadamente $15 \mathrm{mg} . l^{-1}$ ) nesta fase anóxica. 


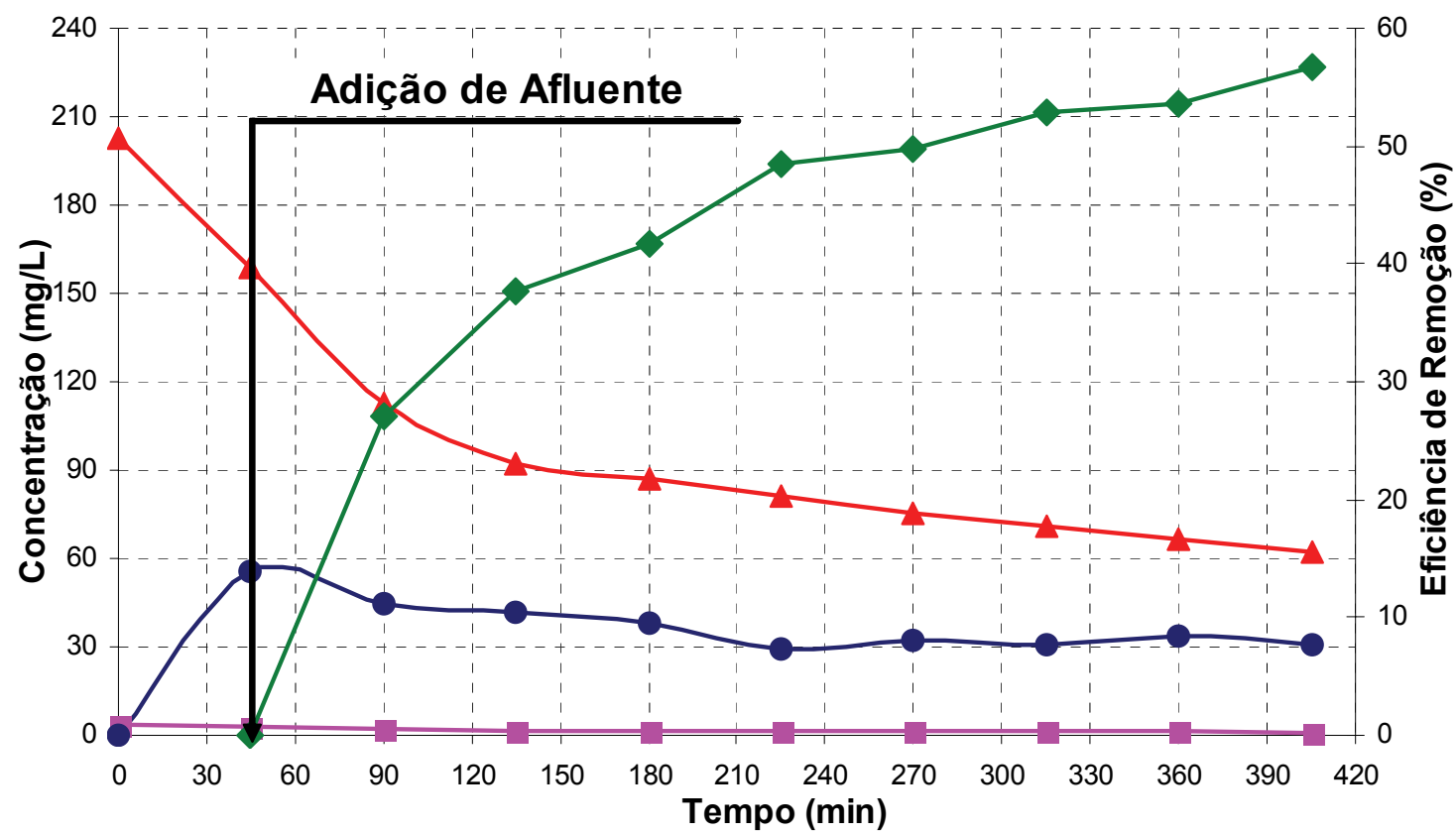

Figura 56: Verficação da desnitrificação na Etapa 3 com adição de afluente na fase anóxica proveniente de reator metanogênico. N-Amoniacal $(\mathbf{O})$, N-Nitrato $(\square)$, N-Nitrito $(\Delta)$ e Eficiência de Remoção de Nitrogênio $(\diamond)$.

Até aproximadamente 120 minutos, a velocidade de desnitrificação foi de $50,4 \mathrm{mgN}$ $\mathrm{NO}_{2}^{-} \cdot l^{-1}, \mathrm{~h}^{-1}$. Após esse tempo, verifica-se que a desnitrificação, provavelmente endógena, tem velocidade menor do que na desnitrificação heterotrófica $\left(6,6 \mathrm{mgN}-\mathrm{NH}_{4}{ }^{+} \cdot l^{-1} \cdot \mathrm{h}^{-1}\right)$. O tempo utlizado para a fase desnitrificante, neste caso, não foi suficiente.

Tabela 16: Coeficientes cinéticos obtidos pelo modelo convencional de remoção de nitrogênio aplicado à ETAPA 3 na fase desnitrificante, com adição de afluente proveniente de reator metanogênico.

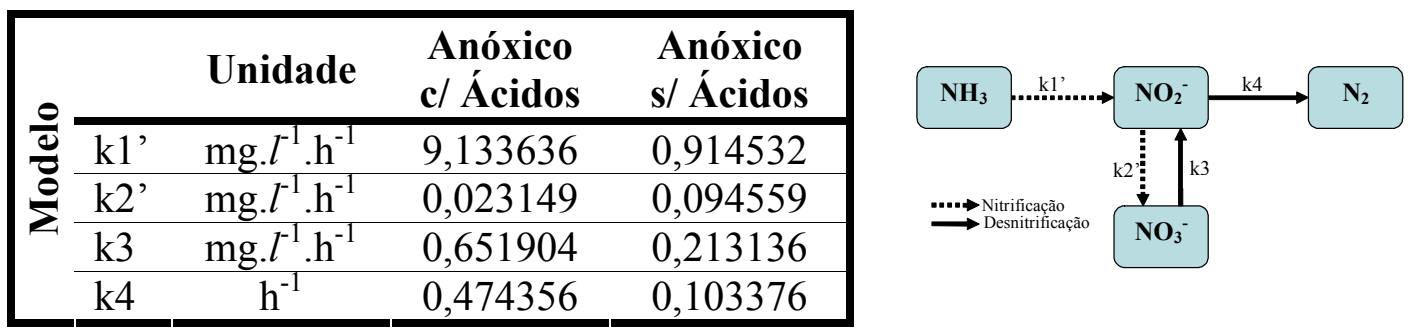

Verifica-se na Tabela 16, do modelo cinético convencional, que o comportamento do sistema foi diferente: na presença de ácidos voláteis, a desnitrificação (k4) foi aproximadamente 4,5 vezes maior do que na ausência de ácidos voláteis, ou seja, a desnitrificação heterotrófica foi aproximadamente 4,5 vezes maior do que a denitrificação endógena. A redução de nitrato a nitrito $(\mathrm{k} 3)$ foi aproximadamente 3 vezes maior na presença 
de ácidos voláteis. Porém, observa-se na Tabela 16, que os coeficientes que indicam a nitrificação (k1' e k2') foram diferentes de zero, tanto na presença de ácidos voláteis no meio líquido, quando na ausência destes, o que não pode ser possível em processos convencionais de desnitrificação. O coeficiente cinético k1', nesta fase anóxica, quando os ácidos voláteis estão presentes, tem um valor muito elevado $\left(\mathrm{k} 1^{\prime}=9,133636 \mathrm{mg} \cdot l^{-1} \cdot \mathrm{h}^{-1}\right)$ em comparação com este mesmo coeficiente na ausência de ácidos $\left(\mathrm{k} 1^{\prime}=0,914532\right)$. Portanto, será aplicado o modelo ANAMMOX, conforme mostrado na Tabela 17.

Tabela 17: Coeficientes cinéticos obtidos pelo modelo não-convencional de remoção de nitrogênio aplicado à ETAPA 3 na fase desnitrificante, com adição de afluente proveniente de reator metanogênico.

\begin{tabular}{|c|c|c|c|c|}
\hline \multirow{6}{*}{ 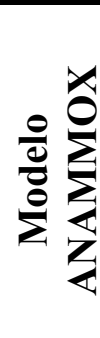 } & & Unidade & $\begin{array}{l}\text { Anóxico } \\
\text { c/ Ácidos }\end{array}$ & $\begin{array}{l}\text { Anóxico } \\
\text { s/ Ácidos }\end{array}$ \\
\hline & $\mathrm{k} 1{ }^{\prime}$ & $\mathrm{mg} \cdot \mathrm{l}^{-1} \cdot \mathrm{h}^{-1}$ & \multirow{5}{*}{$\begin{array}{c}\text { Não } \\
\text { Convergiu! }\end{array}$} & 0,000000 \\
\hline & $\mathrm{k} 2{ }^{\prime}$ & $\mathrm{mg} \cdot l^{-1} \cdot \mathrm{h}^{-1}$ & & 0,000000 \\
\hline & k3 & $\mathrm{mg} \cdot l^{-1} \cdot \mathrm{h}^{-1}$ & & 0,118590 \\
\hline & $\mathrm{k} 4$ & $\mathrm{~h}^{-1}$ & & 0,091290 \\
\hline & $\mathrm{k} 5$ & $\mathrm{~h}^{-1}$ & & 0,028267 \\
\hline
\end{tabular}

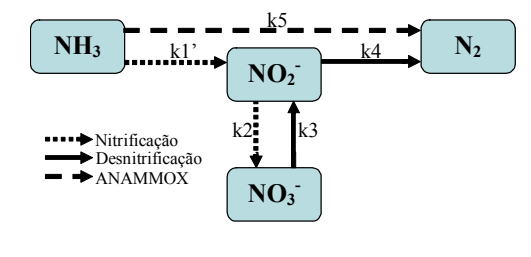

O resultado do modelo que inclui o processo ANAMMOX, mostrado na Tabela 17, não convergiu quando os ácidos voláteis estavam presentes. Portanto, nenhuma conclusão pode ser aferida ao comportamento anômalo do modelo cinético convencional na presença de ácidos voláteis. Já na ausência destes ácidos, verifica-se que os coeficientes cinéticos de nitrificação (k1' e k2') foram nulos. O coeficiente $\mathrm{k} 3$, na ausência de ácidos, foi aproximadamente 55\% menor no modelo ANAMMOX do que no modelo convencional. Verifica-se que o coeficiente $\mathrm{k} 5$, que indica a presença do processo ANAMMOX, foi baixo $\left(\mathrm{k} 5=0,028267 \mathrm{~h}^{-1}\right)$ e foi aproximadamente $30 \%$ menor do que o coeficiente de desnitrificação convencional k4. 


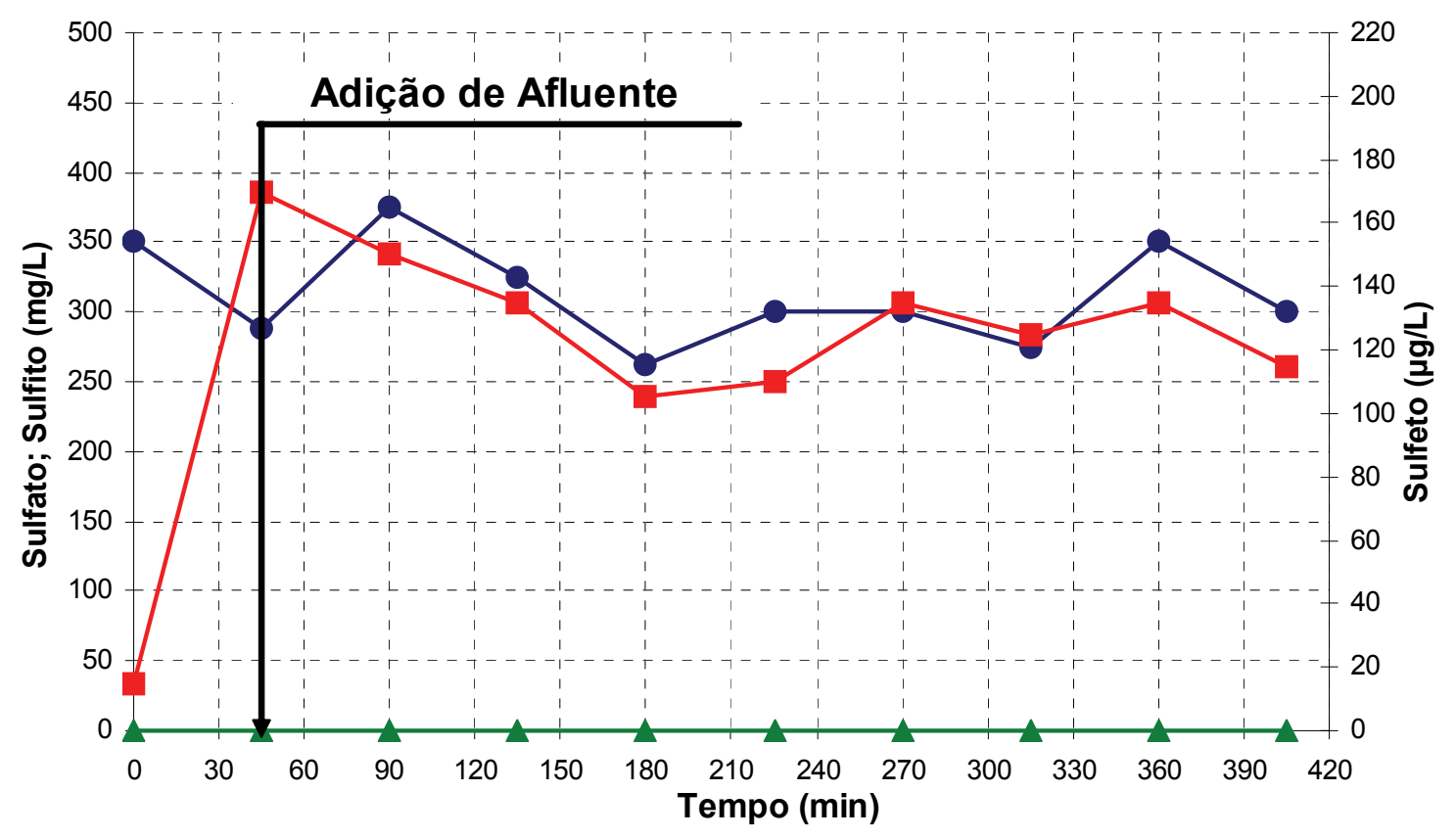

Figura 57: Acompanhamento dos compostos de enxofre na fase anóxica da Etapa 3 com adição de afluente proveniente de reator metanogênico. Sulfato $(\mathbf{O})$, Sulfeto $(\square)$, Sulfito $(\mathbf{\Delta})$.

Na Figura 57, nos tempos entre 90 e 180 minutos, tanto o sulfato como o sulfeto têm decréscimos simultâneos. Na fase anóxica, a tendência seria o decréscimo de compostos oxidados e o respectivo acréscimo de compostos reduzidos, como o sulfeto. $\mathrm{O}$ decréscimo de compostos oxidados e reduzidos de enxofre induz à hipótese de que está ocorrendo a redução de sulfato e o respectivo consumo de sulfeto provavelmente pela desnitrificação autotrófica, porém esta tendência não se prossegue após o tempo 180 minutos. Não foi detectada a presença de sulfito em todo experimento. 


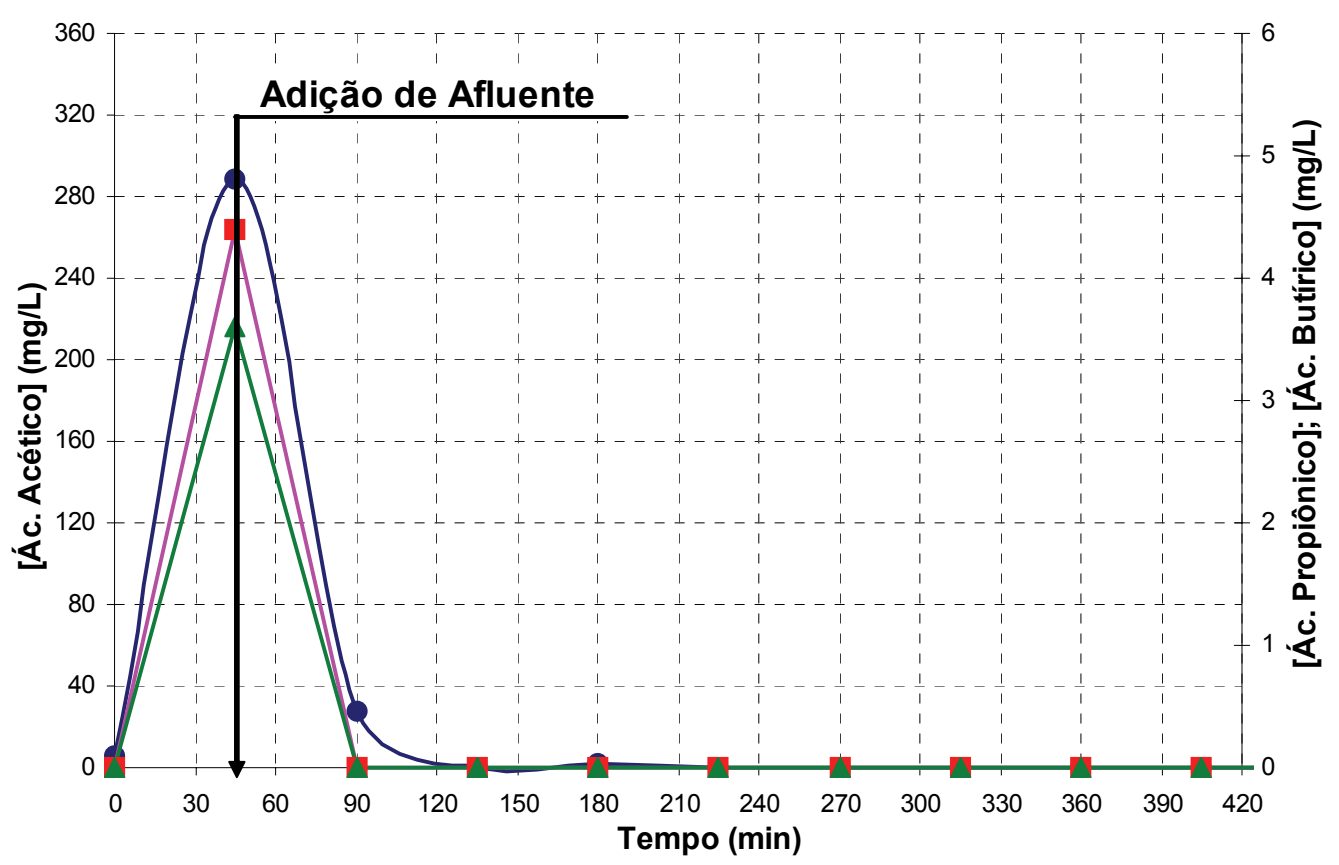

Figura 58: Acompanhamento de ácidos orgânicos na fase anóxica da Etapa 3 com adição de afluente

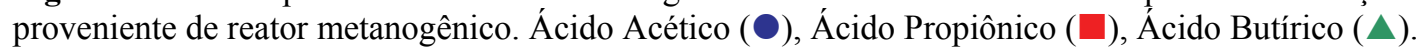

Nota-se na Figura 58 que havia uma baixa concentração de ácidos (em relação à outros experimentos), pois o afluente adicionado originou-se do reator metanogênico. Neste caso, verifica-se que pode ser interessante utilizar, para desnitrificação, o efluente do reator sulfetogênico, por apresentar maior concentração de ácidos e sulfeto, o qual também poderia ser utilizado pela desnitrificação autotrófica.

\subsubsection{ETAPA 3 - Adição de afluente na fase anóxica proveniente de reator sulfetogênico}

De acordo com a Figura 59, a concentração de nitrato da fase aeróbia anterior foi insignificante em relação a de nitrito e este foi consumido completamente no tempo 315 minutos.

Utilizou-se, neste experimento, $1500 \mathrm{~mL}$ do efluente da reator sulfetogênico para desnitrificação. Observa-se que houve um pequeno decréscimo de nitrogênio amoniacal entre os tempos 135 e 225 minutos, ainda na presença de nitrito. Entre os tempos 315 e 360 minutos, houve também um pequeno decréscimo do nitrogênio amoniacal, porém, neste caso, a presença de nitrito foi baixa ou nula. 


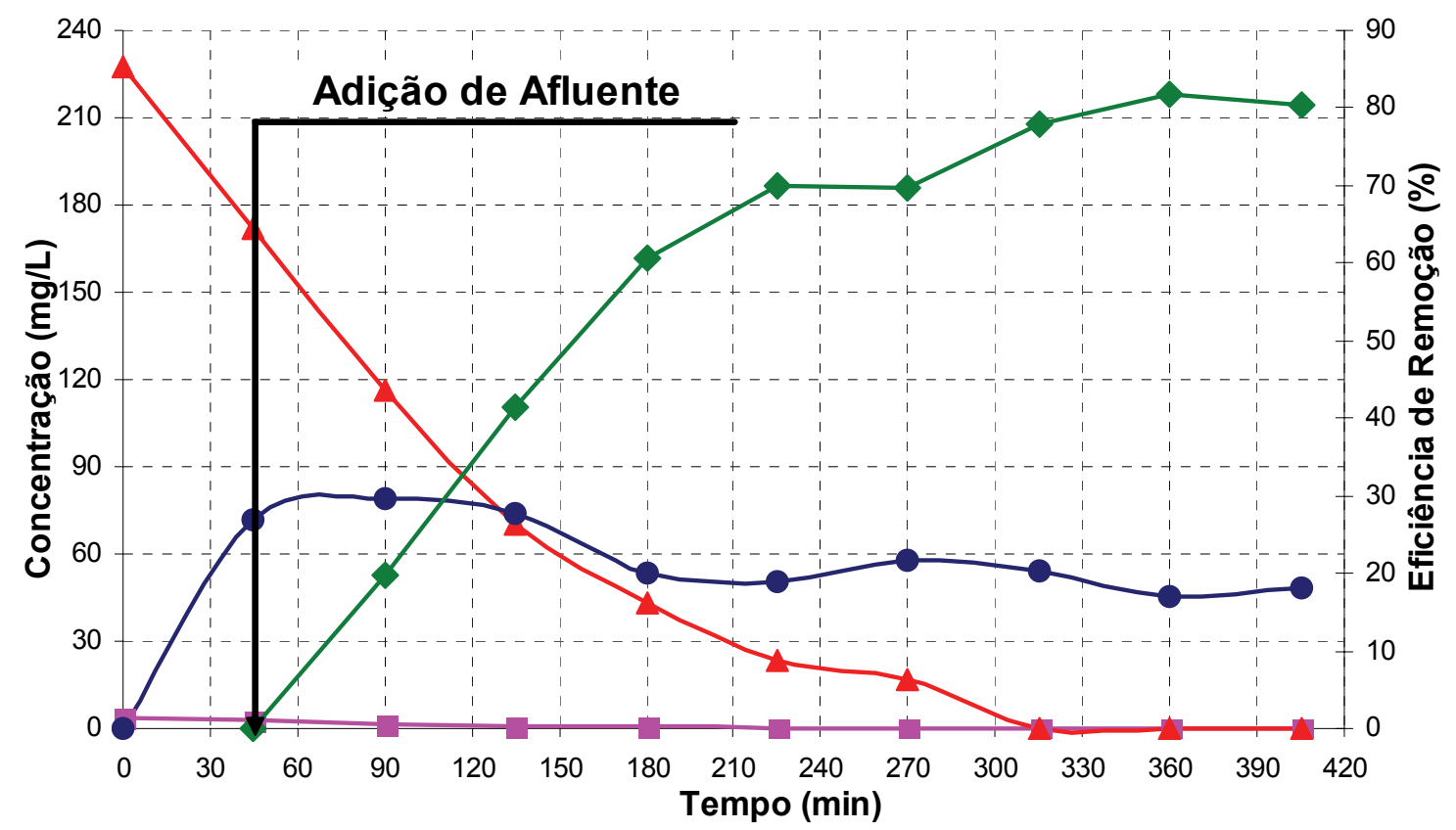

Figura 59: Verficação da desnitrificação na Etapa 3 com adição de afluente na fase anóxica proveniente de reator sulfetogênico. N-Amoniacal $(\mathbf{O})$, N-Nitrato $(\square)$, N-Nitrito $(\boldsymbol{\Delta})$ e Eficiência de Remoção de Nitrogênio $(\diamond)$.

De acordo com as Figura 59 e Figura 61, mesmo com consumo dos ácidos no tempo 180 minutos, a desnitrificação ocorreu com uma velocidade menor $\left(18,0 \mathrm{mgN}-\mathrm{NO}_{2}^{-} \cdot l^{-1} \cdot \mathrm{h}^{-1}\right)$ do que na presença dos ácidos $\left(63,0 \mathrm{mgN}-\mathrm{NO}_{2}^{-} \cdot l^{-1} \cdot \mathrm{h}^{-1}\right)$.

Tabela 18: Coeficientes cinéticos obtidos pelo modelo convencional de remoção de nitrogênio aplicado à ETAPA 3 na fase desnitrificante, com adição de afluente proveniente de reator sulfetogênico.

\begin{tabular}{|c|c|c|c|c|c|c|c|}
\hline & & Unidade & $\begin{array}{l}\text { Anóxico } \\
\text { c/ Ácidos }\end{array}$ & $\begin{array}{l}\text { Anóxico } \\
\text { s/ Ácidos }\end{array}$ & $\mathrm{NH}_{3}$ & & $\stackrel{\mathrm{k} 4}{\longrightarrow}$ \\
\hline$\frac{0}{0}$ & $\mathrm{k} 1{ }^{\prime}$ & $\mathrm{mg} \cdot l^{-1} \cdot \mathrm{h}^{-1}$ & 7,101261 & 0,000000 & & & \\
\hline$\frac{0}{2}$ & $\mathrm{k} 2$ ' & $\mathrm{mg} \cdot l^{-1} \cdot \mathrm{h}^{-1}$ & 0,001637 & 0,339762 & $\ldots \rightarrow$ Nitrifici & $\vdots 1$ & \\
\hline & k3 & $\mathrm{mg} \cdot l^{-1} \cdot \mathrm{h}^{-1}$ & 0,490529 & 0,000000 & & $\mathrm{NO}_{3}{ }^{-}$ & \\
\hline & $\mathrm{k} 4$ & $\mathrm{~h}^{-1}$ & 0,660479 & 0,800781 & & & \\
\hline
\end{tabular}

Verifica-se pelos coeficientes cinéticos do modelo nitrificante/desnitrificante convencional, mostrado na Tabela 18 que, na presença de ácidos, neste período anóxico, o coeficiente $\mathrm{k} 1$ ' foi igual a $7,101261 \mathrm{mg} \cdot l^{-1} \cdot \mathrm{h}^{-1}$. Este valor é relativamente alto, porém, neste caso,é muito improvável que bioquimicamente este processo nitrificante ocorra. O coeficiente $\mathrm{k} 2$ ’ também foi diferente de zero, porém com um valor inferior $\left(\mathrm{k} 2^{\prime}=0,001637 \mathrm{mg} \cdot \mathrm{l}^{-1} \cdot \mathrm{h}^{-1}\right)$. 
Observa-se também a ocorrência da redução de nitrato a nitrito $\left(\mathrm{k} 3=0,490529 \mathrm{mg} \cdot \mathrm{l}^{-1} \cdot \mathrm{h}^{-1}\right)$ e da desnitrificação heterotrófica, pois havia a presença de ácidos voláteis $\left(\mathrm{k} 4=0,660479 \mathrm{~h}^{-1}\right)$.

$\mathrm{Na}$ Tabela 18 verifica-se que, na ausência de ácidos voláteis, o coeficiente k1' foi igual a zero e foi observada a oxidação de nitrito a nitrato $\left(\mathrm{k} 2^{\prime}=0,339762 \mathrm{mg} \cdot \mathrm{l}^{-1} \cdot \mathrm{h}^{-1}\right)$. Não foi identificada a redução de nitrato à nitrito $(\mathrm{k} 3)$, porém a redução de nitrito a nitrogênio gasoso (k4) foi 12\% maior do que na presença de ácidos voláteis. A atividade redutora nesta fase anóxica, na ausência de ácidos voláteis, foi voltada totalmente para a desnitrificação (k4), porém não se sabe o motivo deste comportamento.

Tabela 19: Coeficientes cinéticos obtidos pelo modelo não-convencional de remoção de nitrogênio aplicado à ETAPA 3 na fase desnitrificante, com adição de afluente proveniente de reator sulfetogênico.

\begin{tabular}{|c|c|c|c|c|}
\hline \multirow{6}{*}{ 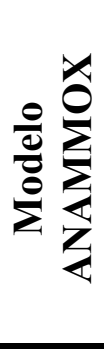 } & & Unidade & $\begin{array}{l}\text { Anóxico } \\
\text { c/ Ácidos }\end{array}$ & $\begin{array}{l}\text { Anóxico } \\
\text { s/ Ácidos }\end{array}$ \\
\hline & $\mathrm{k} 1{ }^{\prime}$ & $\mathrm{mg} \cdot \mathrm{l}^{-1} \cdot \mathrm{h}^{-1}$ & 0,000000 & 0,000000 \\
\hline & $\mathrm{k} 2^{\prime}$ & $\mathrm{mg} \cdot \mathrm{l}^{-1} \cdot \mathrm{h}^{-1}$ & 0,000000 & 0,339735 \\
\hline & $\mathrm{k} 3$ & $\mathrm{mg} \cdot \mathrm{l}^{-1} \cdot \mathrm{h}^{-1}$ & 0,489881 & 0,000000 \\
\hline & $\mathrm{k} 4$ & $\mathrm{~h}^{-1}$ & 0,591583 & 0,800782 \\
\hline & $\mathrm{k} 5$ & $\mathrm{~h}^{-1}$ & 0,103492 & 0,000000 \\
\hline
\end{tabular}

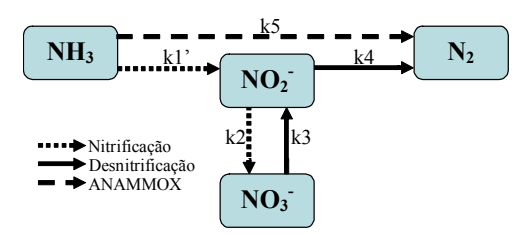

Verifica-se pela Tabela 19 que, na presença de ácidos voláteis na fase anóxica, os coeficientes cinéticos do modelo k1' e k2' foram nulos, ou seja, não foi identificada atividade oxidante no sistema. Observa-se a redução de nitrato à nitrito $\left(\mathrm{k} 3=0,489881 \mathrm{mg} \cdot l^{-1} \cdot \mathrm{h}^{-1}\right)$ e a desnitrificação heterotrófica $\left(\mathrm{k} 4=0,591583 \mathrm{~h}^{-1}\right)$. Além da desnitrificação convencional, observa-se também a atividade ANAMMOX, evidenciada, pelo coeficiente $\mathrm{k} 5$ de primeira ordem $\left(0,103492 \mathrm{~h}^{-1}\right)$. A atividade ANAMMOX foi aproximadamente $75 \%$ menor do que a atividade desnitrificante convencional.

Nesta fase anóxica, na ausência de ácidos voláteis no meio líquido, segundo a Tabela 19, os coeficientes cinéticos k1', k2', k3 e k4 do modelo que inclui o processo ANAMMOX, foram muito semelhantes ao do modelo convencional (Tabela 18). Neste caso, não foi identificada a oxidação de nitrogênio amoniacal anoxicamente (ANAMMOX), evidenciada pelo coeficiente cinético $\mathrm{k} 5$, porém, não se sabe o por quê do comportamento anômalo do coeficiente cinético de nitratação k2'. 


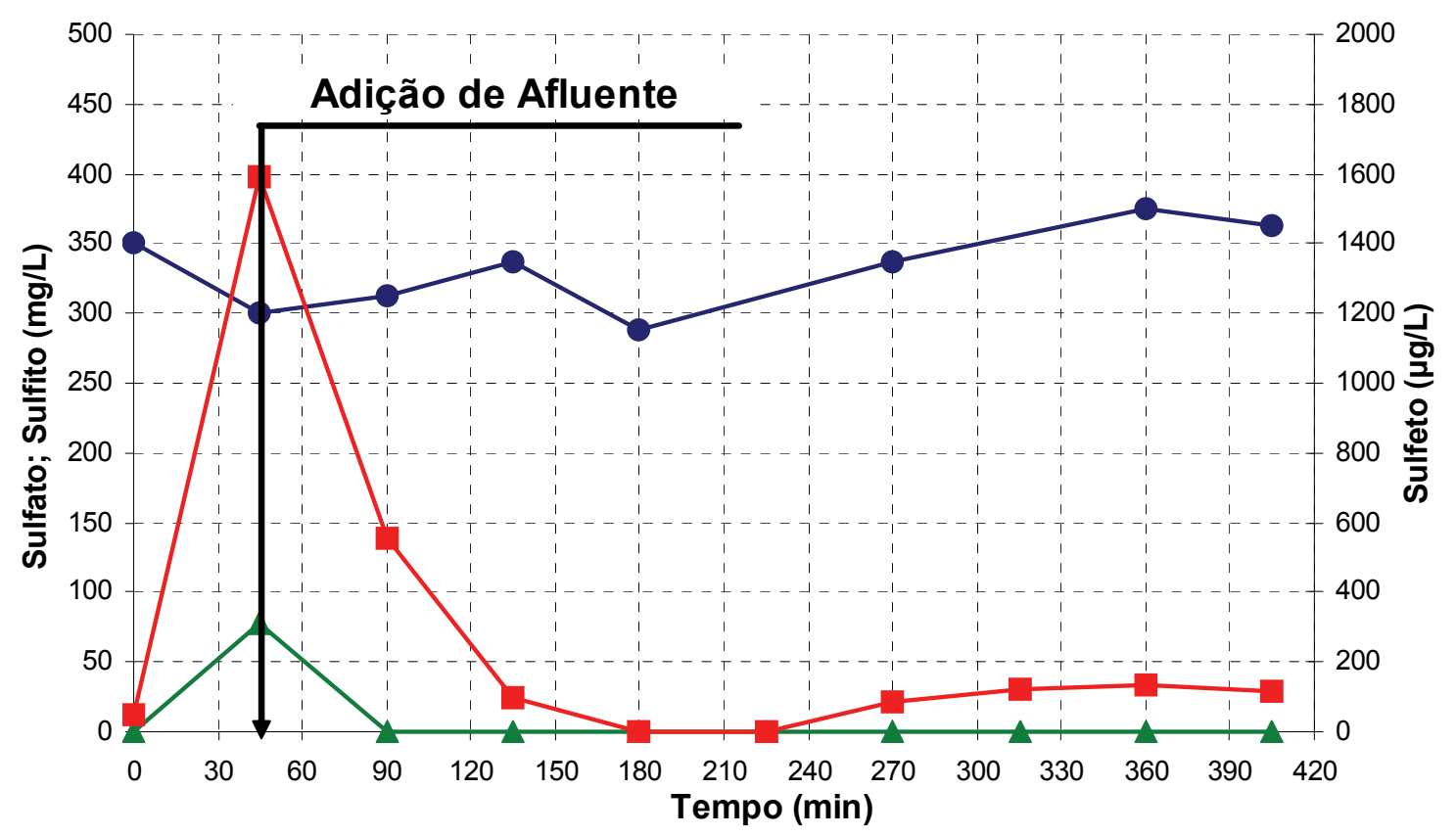

Figura 60: Acompanhamento dos compostos de enxofre na fase anóxica da Etapa 3 com adição de afluente

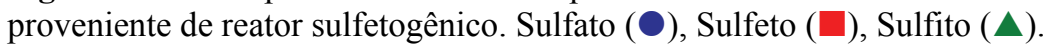

Segundo a Figura 60, o sulfito foi consumido completamente e a concentração de sulfeto do afluente adicionado foi relativamente elevada (1600 $\left.\mu \mathrm{g} . l^{-1}\right)$. O sulfeto foi consumido em sua totalidade no tempo de 180 minutos, porém no tempo 225 minutos, observa-se um acréscimo de sulfeto, provavelmente devido a redução endógena de sulfato, pois não se identificam ácidos voláteis presentes após este momento. Houve uma sensível tendência de aumento de sulfato.

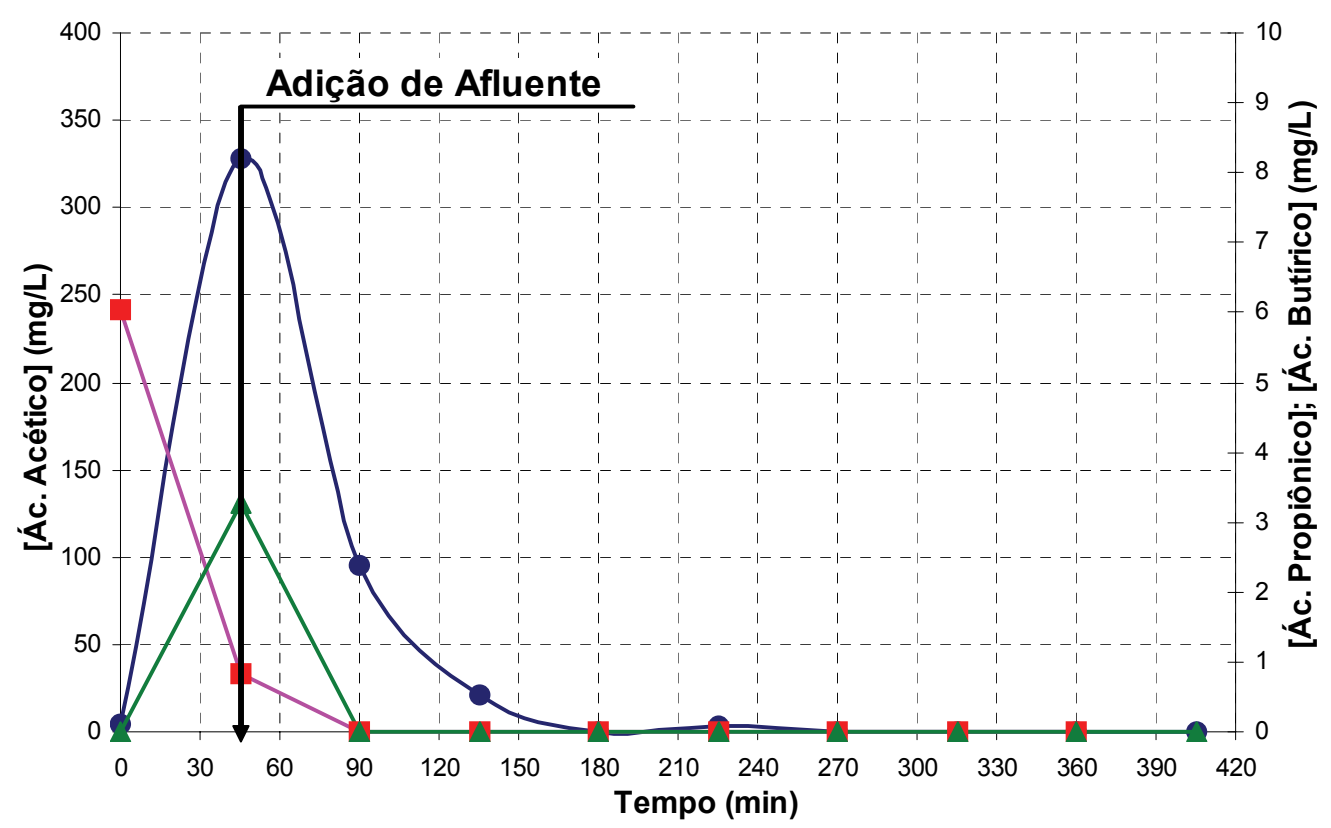

Figura 61: Acompanhamento de ácidos orgânicos na fase anóxica da Etapa 3 com adição de afluente

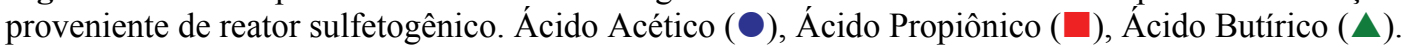


Verifica-se na Figura 61, que os ácidos voláteis foram completamente consumidos até o tempo de 180 minutos. O comportamento de decaimento do ácido acético foi semelhante ao decaimento do sulfeto (Figura 60), porém acredita-se que foi uma simples coincidência, sem haver relação de um composto com outro.

\subsubsection{ETAPA 3 -Adição de afluente na fase anóxica proveniente de reator sulfetogênico}

Utilizou-se neste experimento $1500 \mathrm{~mL}$ do efluente do reator sulfetogênico na fase anóxica e observa-se, segundo a Figura 62, um rápido consumo do nitrito. Mais uma vez a concentração de nitrato na fase aeróbia anterior foi insignificante em relação à concentração de nitrito. A partir do tempo 180 minutos, verifica-se um acréscimo de eficiência do sistema devido ao decréscimo de nitrogênio amoniacal (remoção de aproximadamente $23 \mathrm{mg} . l^{-1}$ ).

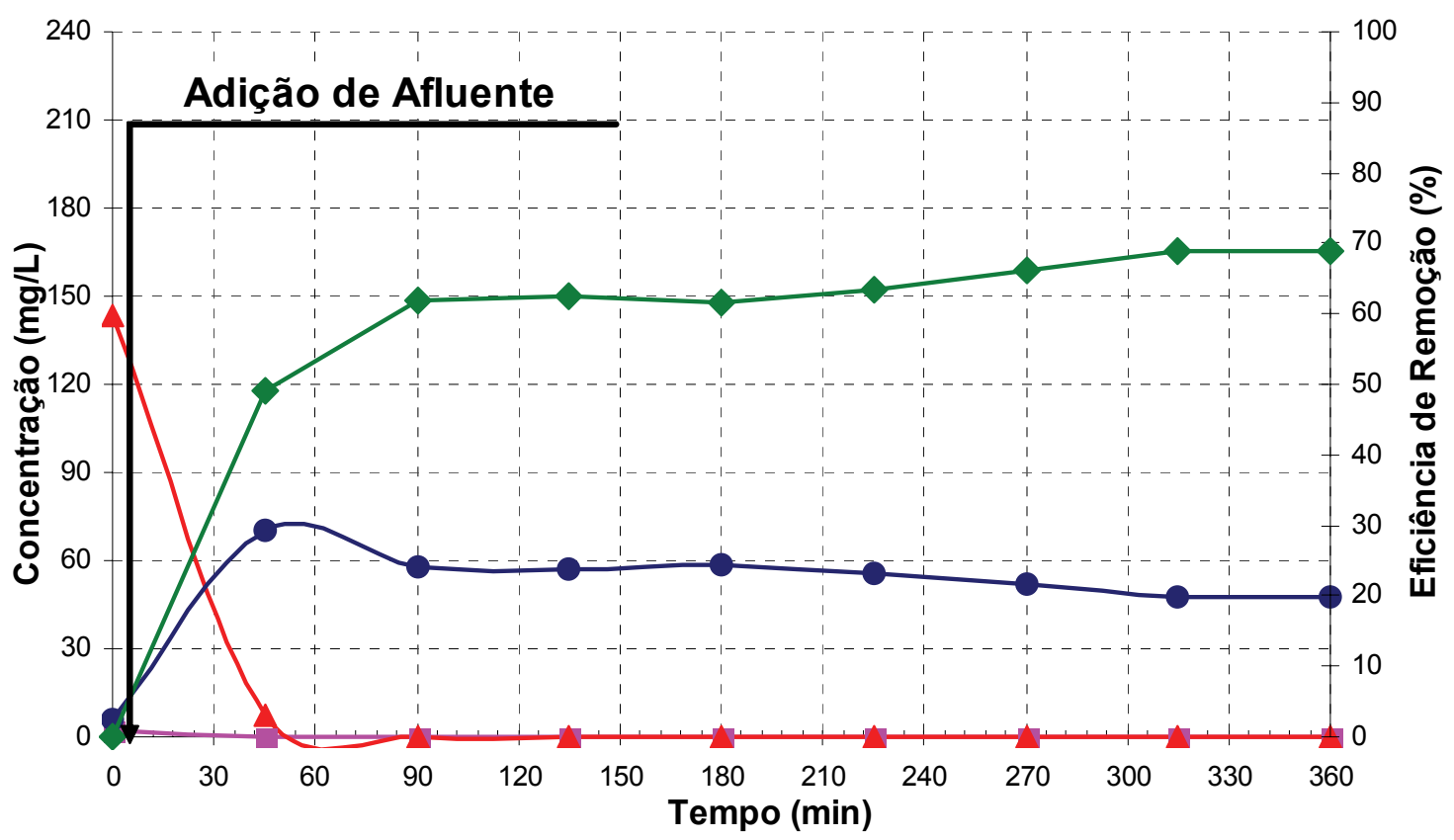

Figura 62: Verficação da desnitrificação na Etapa 3 com adição de afluente na fase anóxica proveniente de reator sulfetogênico. N-Amoniacal $(\mathbf{O})$, N-Nitrato $(\square)$, N-Nitrito $(\boldsymbol{\Delta})$ e Eficiência de Remoção de Nitrogênio $(\diamond)$.

Neste experimento, a velocidade de consumo de nitrito foi muito superior do que em outros casos. Acredita-se que a concentração de nitrito inicial na fase desnitrificante influencia na velocidade de desnitrificação. Neste ensaio, a concentração inicial de N-nitrito foi de aproximadamente $140 \mathrm{mg} . l^{-1}$ e a velocidade de desnitrificação foi de $\left(182,4 \mathrm{mgN}-\mathrm{NO}_{2}{ }^{-}\right.$ $\left.\cdot l^{-1} \cdot \mathrm{h}^{-1}\right)$. No experimento anterior (Figura 59), a concentração inicial de N-nitrito foi de 
aproximadamente $220 \mathrm{mg} . l^{-1}$ e a velocidade máxima de desnitrificação foi muito menor $(63,0$ $\left.\operatorname{mgN}-\mathrm{NO}_{2}^{-} \cdot l^{-1} \cdot \mathrm{h}^{-1}\right)$.

Tabela 20: Coeficientes cinéticos obtidos pelo modelo convencional de remoção de nitrogênio aplicado à ETAPA 3 na fase desnitrificante, com adição de afluente proveniente de reator sulfetogênico.

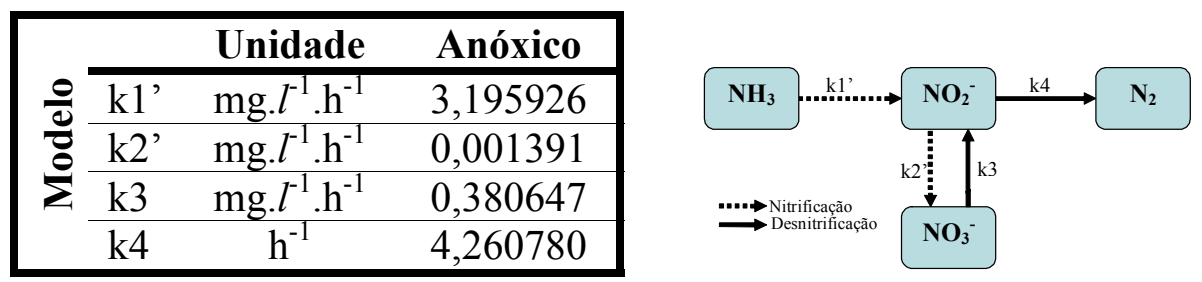

Observa-se na Tabela 20 que, neste fase anóxica, está ocorrendo a oxidação do nitrogênio amoniacal $\left(\mathrm{k} 1^{\prime}\right)$ e também a nitratação $(\mathrm{k} 2$ '), porém a ocorrência destes dois fenômenos em fase anóxica é improvável. Observa-se a redução de nitrato à nitrito $(\mathrm{k} 3=$ $\left.0,380647 \mathrm{mg} \cdot \mathrm{l}^{-1} \cdot \mathrm{h}^{-1}\right)$ e um elevado coeficiente desnitrificante de primeira ordem $(\mathrm{k} 4=$ $4,260780 \mathrm{~h}^{-1}$ ), indicando uma elevada atividade desnitrificante.

Apesar dos coeficientes k1' e k2' serem diferentes de zero nesta fase, não é possível a aplicação do modelo que engloba o processo ANAMMOX, pois uma condição fundamental para aplicação deste modelo complementar é a presença de nitrito para que o processo ANAMMOX ocorra.

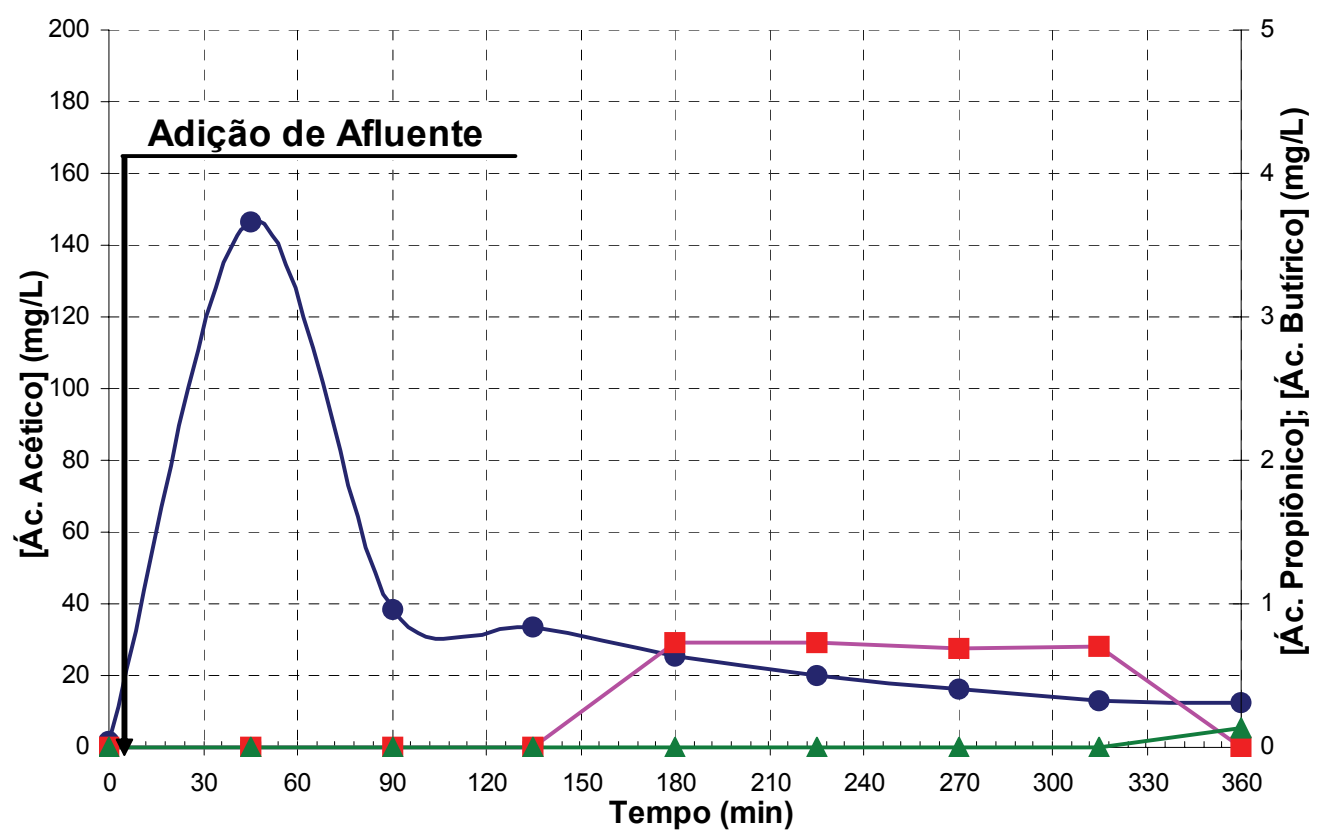

Figura 63: Acompanhamento de ácidos orgânicos na fase anóxica da Etapa 3 com adição de afluente

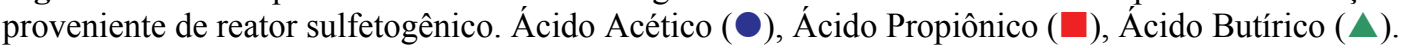


De acordo com a Figura 62, o nitrito foi consumido completamente no tempo 45 minutos, porém, observa-se na Figura 63 que os ácidos foram consumidos com uma velocidade superior até 90 minutos e após esse tempo a velocidade de consumo foi relativamente baixa, provavelmente devido a utilização destes para redução dissimilativa de sulfato.

\subsection{ENSAIOS COMPLEMENTARES}

Após o término das etapas principais previstas, foram realizados alguns ensaios complementares para tentar elucidar alguns aspectos julgados importantes dos processos.

\subsubsection{Utilização do efluente original da indústria diluído na fase nitrificante}

Neste ensaio utilizou-se aeração de aproximadamente de 5 a 6 litros e efluente "sintético", composto pelo efluente original bruto da indústria. A composição deste afluente foi de $30 \mathrm{~g}$ de bicarbonato de sódio, $30 \mathrm{~mL}$ de afluente bruto da indústria, diluído em 10 litros de água proveniente do sistema de abastencimento d'água local.

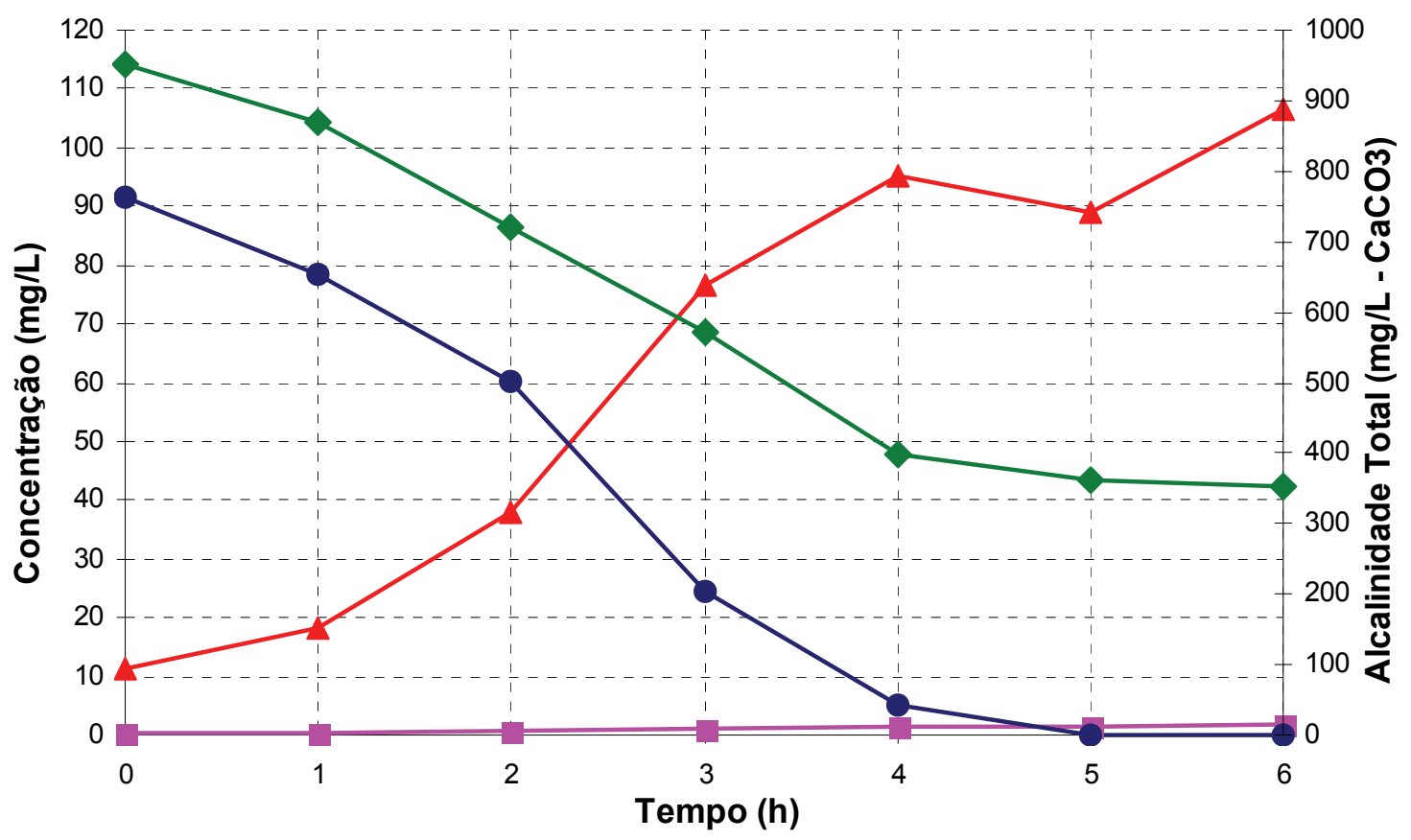

Figura 64: Utilização do efluente original da indústria diluído na fase nitrificante. N-Amoniacal (O), N-Nitrato $(\square)$, N-Nitrito $(\boldsymbol{\Delta})$ e Alcalinidade Total $(\diamond)$. 
Verifica-se neste ensaio (Figura 64) que a conversão do nitrogênio amoniacal se deu por completo no tempo aproximado de 5 horas. Desta vez não foi observada a limitação pela alcalinidade e nota-se que a nitrificação se deu basicamente até nitrito.

O comportamento da fase nitrificante com o efluente bruto diluído foi semelhante à dos outros experimentos nos quais foram utilizados efluentes do reator metanogênico (com concentrações de ácidos voláteis abaixo do limite de detecção). O decaimento da alcalinidade total seguiu padrão similar ao decaimento do nitrogênio amoniacal (coeficiente de correlação $0,995)$.

Não foi constatado nenhum comportamento estranho pela utilização direta do efluente diluído da indústria, indicando a viabilidade desta aplicação direta.

Tabela 21: Coeficientes cinéticos obtidos pelo modelo convencional de remoção de nitrogênio aplicado ao ensaio complementar que utiliza efluente original da indústria diluído na fase nitrificante.

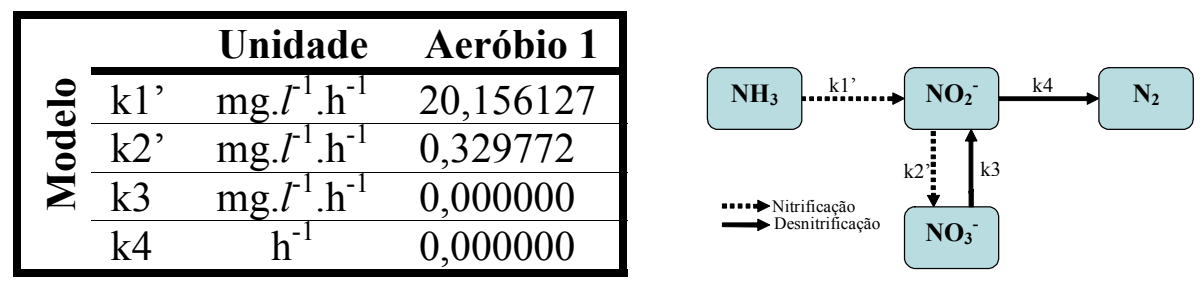

Mesmo utilizando o efluente original da indústria diluído e alcalinizado, observa-se pela Tabela 21 que o produto principal da nitrificação foi o nitrito, pois k1' >> k2'. Neste caso, utilizou-se uma vazão de ar de 5 a 6 litros e a relação k1'/k2' foi superior a 60, ou seja, a oxidação de amônia à nitrito foi 60 vezes superior do que a nitratação. Os coeficientes k3 e k4 foram iguais a zero, ou seja, não houve a desnitrificação nesta fase aeróbia.

\subsubsection{Verificação da nitrificação e do possível processo anammox sem interferentes}

Com a verificação do decaimento de uma pequena parcela de nitrogênio amoniacal, em algumas fases desnitrificantes do reator com biomassa imobilizada, foi realizado um experimento para verificação do consumo de $\mathrm{N}$-amoniacal sem nenhum outro interferente (sulfato, sulfeto, ácidos, etc) e também para avaliação da nitrificação sem possíveis interferentes. Preparou-se uma água residuária sintética contendo apenas nitrogênio amoniacal $\left(180 \mathrm{mgN}-\mathrm{NH}_{4}{ }^{+} \cdot l^{-1}\right)$ e alcalinidade $\left(1500 \mathrm{mgHCO}_{3}{ }^{-} \cdot l^{-1}\right)$ para ser utilizada neste experimento. 


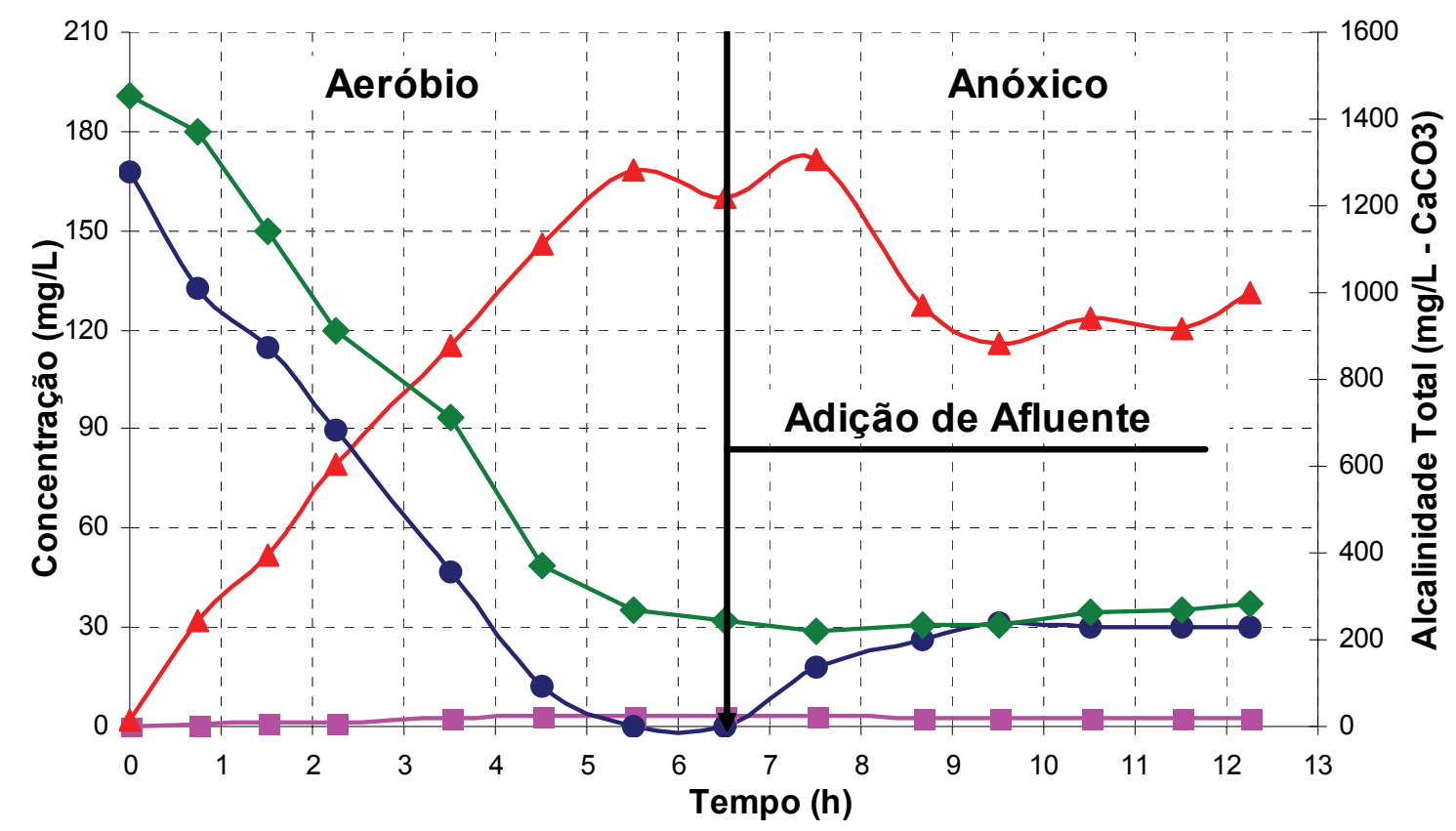

Figura 65: Verificação da nitrificação e do possível processo anammox sem interferentes na fase aeróbia e anóxica. N-Amoniacal ( $)$, N-Nitrato $(\square)$, N-Nitrito $(\mathbf{\Delta})$ e Alcalinidade Total $(\diamond)$.

Mesmo sem qualquer outro íon (sulfato, sulfeto, etc), segundo a Figura 65, houve o acúmulo de nitrito e a concentração de nitrato foi insignificante. Isto se deve provavelmente à biomassa já adaptda para nitrificação até nitrito. Verifica-se também que o decréscimo do nitrogênio amoniacal coincide com o decréscimo da alcalinidade total (coeficiente de correlação ' $r$ ' igual a 0,993). O tempo necessário para nitrificação foi de 5,5 horas.

No tempo 6,5 horas, cessou-se a aeração e adicionou-se o afluente sintético sem matéria orgânica. Observa-se que deste tempo de 6,5 horas até o tempo 9,5 horas (3 horas de diferença), houve uma elevação do nitrogênio amoniacal e um decréscimo do nitrito.

A partir do tempo 9,5 horas até o final da bateleda, verifica-se que não houve alteração do nitrogênio amoniacal, significando que pode ser necessário outro composto, combinado com o amoniacal, para seu consumo/tranformação.

Tabela 22: Coeficientes cinéticos obtidos pelo modelo convencional de remoção de nitrogênio aplicado ao ensaio complementar para verificação da nitrificação e da desnitrificação do possível processo anammox sem interferentes.

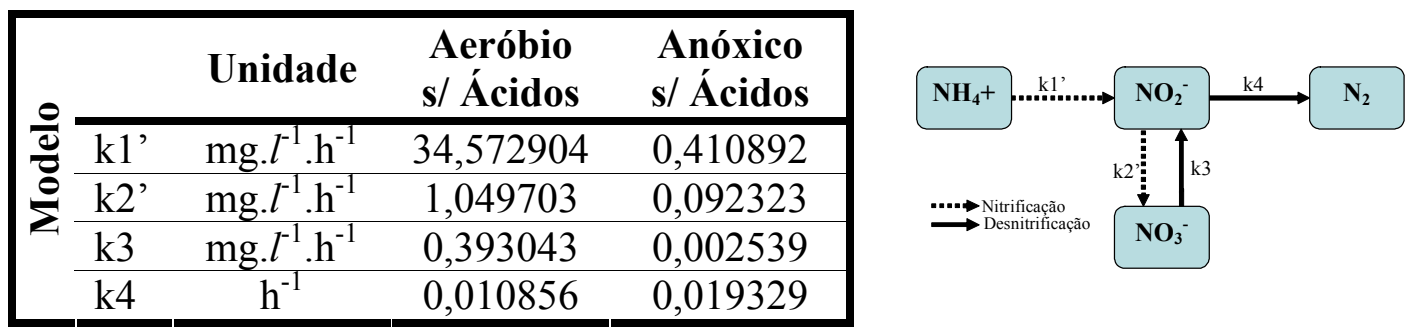


Observa-se na Tabela 22 que, na fase aeróbia, tem-se uma alta atividade nitrificante. $\mathrm{O}$ coeficiente $\mathrm{k} 1^{\prime}\left(34,572904 \mathrm{mg} . \mathrm{l}^{-1} \cdot \mathrm{h}^{-1}\right)$ foi muito maior do que o coeficiente $\mathrm{k} 2$ ' $(1,049703$ $\mathrm{mg} \cdot l^{-1} \cdot \mathrm{h}^{-1}$ ), ou $\mathrm{k} 1^{\prime}>>\mathrm{k} 2$ ', portanto houve o acúmulo de nitrito no sistema. Mesmo com uma alta vazão de ar (4 a 5 L. $\mathrm{min}^{-1}$ ), observa-se, pelos coeficientes k3 e k4 a redução de compostos de nitrogênio.

$\mathrm{Na}$ fase anóxica, observa-se pela Tabela 22 a oxidação de compostos nitrogenados. $\mathrm{O}$ coeficiente k1', que indica a oxidação de nitrogênio amoniacal, e o coeficiente k2', que representa a nitratação ou a oxidação de nitrito à nitrato, foram diferentes de zero. $\mathrm{O}$ coeficiente $\mathrm{k} 3$ foi muito baixo $\left(0,002539 \mathrm{mg} \cdot l^{-1} \cdot \mathrm{h}^{-1}\right)$, indicando uma pequena redução de nitrato à nitrito. $\mathrm{O}$ coeficiente $\mathrm{k} 4$ também apresentou valor baixo, ou seja, a atividade desnitrificante nesta fase anóxica foi bem tímida.

Apesar do cumprimento dos pré-requisitos para aplicação do modelo que inclui o processo ANAMMOX, este não se ajustou bem aos dados experimentais. Os coeficientes do modelo convencional, mostrados pela Tabela 22 da fase anóxica, não apresentam um sentido bioquímico real, portanto, nada se pode aferir neste caso. Porém, os comportamentos anormais, fornecem indícios de ocorrência de outros fatores ou processos desconhecidos, ou apontam às limitações do modelo proposto, como: assimilação de compostos de nitrogênio por microrganismos e efeitos hidrodinâmicos presentes no reator.

\subsubsection{Teste de "Stripping"}

Este ensaio foi realizado para eliminar a suspeita de grandes perdas de nitrogênio amoniacal devido à perda por "stripping". Foi utilizado 8 litros de afluente do reator metanogênico, alcalinizado com $10 \mathrm{~g}$ de bicarbonato de sódio. O meio foi autoclavado na garrafa utilizada para este experimento, assim como mangueiras, difusores de ar e rolha, para eliminar todo e qualquer tipo de contaminação biológica, a fim de garantir apenas perdas de nitrogênio amoniacal por arraste do ar. Utilizou-se a vazão de ar entre 8 e 9 litros por minuto e o pH do sistema permaneceu entre 9,0 e 9,6. 


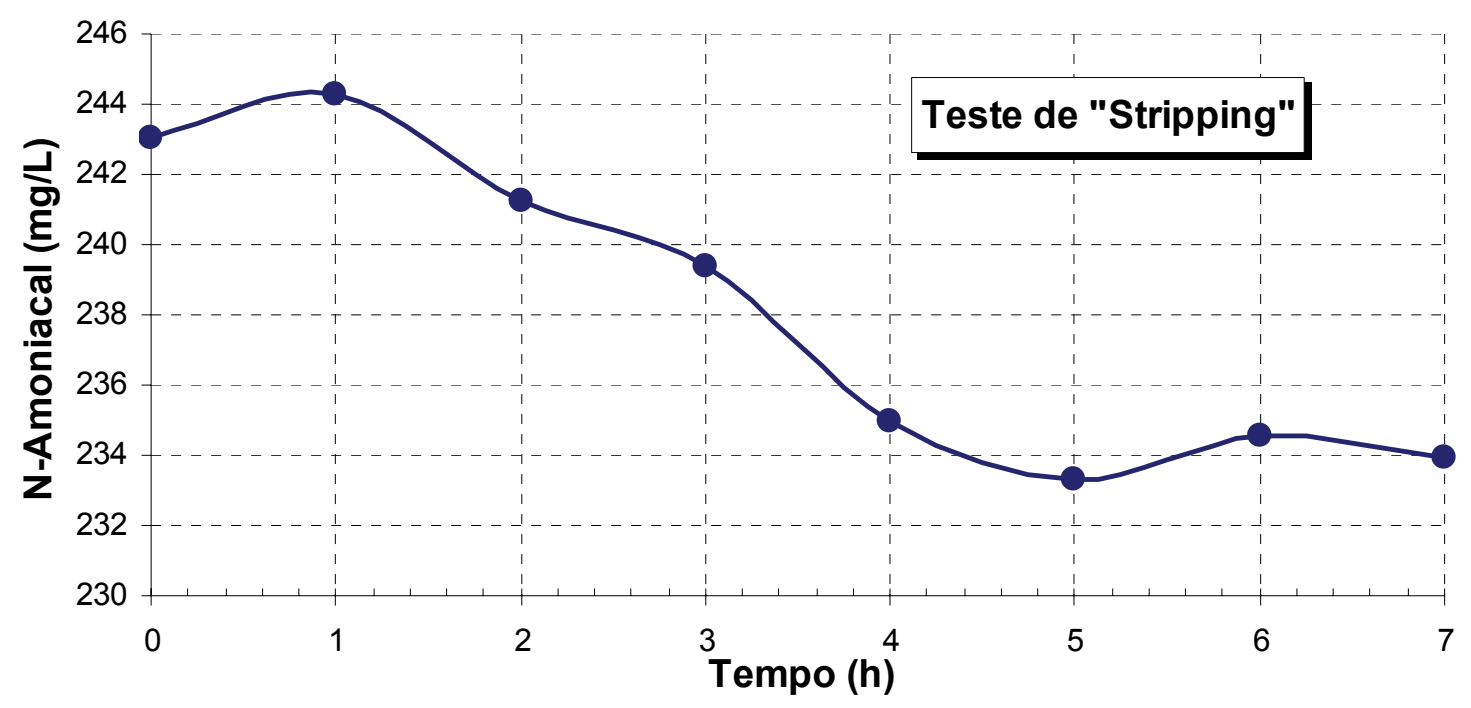

Figura 66: Teste de "Stripping".

Verifica-se pela Figura 66 que, neste teste houve um decaimento do nitrogênio amoniacal máximo de 9,5\% (considerando a maior e a menor concentração) e que não há uma perda constante de nitrogênio amoniacal, pois após o tempo 5 horas, a concentração se manteve estável.

\subsection{EXAMES MICROBIOLÓGICOS}

Foram realizados exames microbiológicos a fim de verificar as morfologias presentes no reator de biomassa suspensa (Etapa 1 e 2) e no reator de biomassa imobilizada (Etapa 3). Foram analisadas amostras sob microscopia de contrate de fase e fluorecência e, em algumas amostras, também foram realizadas microscopia eletrônica de varredura (MEV). Não foram identificados microrganismos que fluorescecem na presença da luz ultra-violeta.

Para avaliação da comunidade microbiana realizou-se ensaios de DGGE (eletroforese em gel de gradiente desnaturante) comparando-se o inóculo inicial utilizado com a biomassa presente no reator de biomassa imobilizada na Etapa 2, assim como a biomassa presente no reator com a biomassa imobilizada na Etapa 3. Além dessas amostras, comparou-se também grânulos presentes no reator de biomassa suspensa na Etapa 2 e também materiais biológicos aderidos nos diversos suportes inertes estudados nos ensaios com microsensores em reator de célula de fluxo. 


\subsubsection{Microscopia ótica da ETAPA 1}

$\mathrm{Na}$ Etapa 1 foram encontrados microrganismos com diversas morfologias: cocos, bacilos, filamentos, disposto de maneiras variadas: em colônias, em aglomerados envoltos por membrana (Clusters) e em tétrade. Verificou-se também que muitos dos microrganismos encontrados possuíam incrustrações internas.
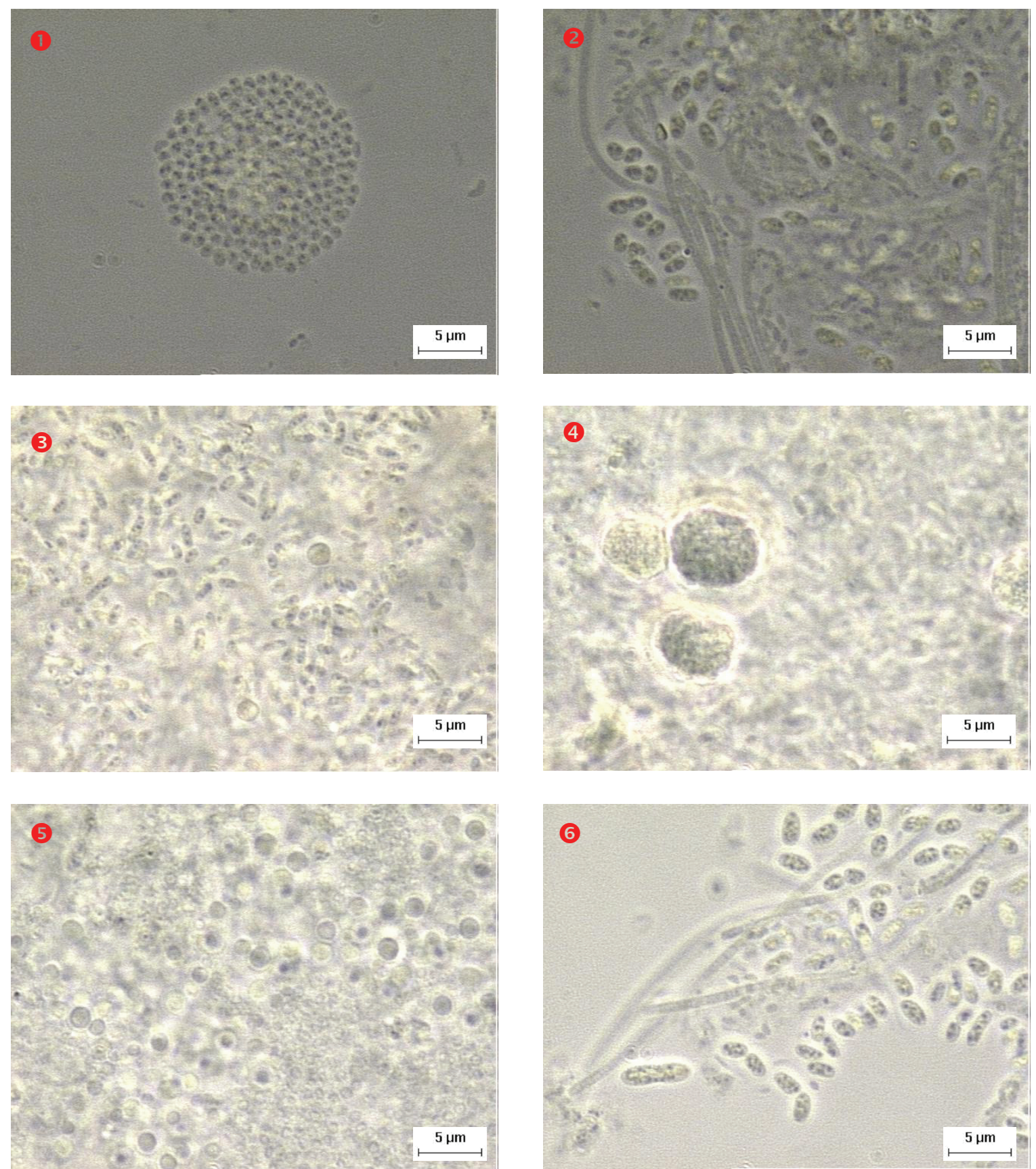

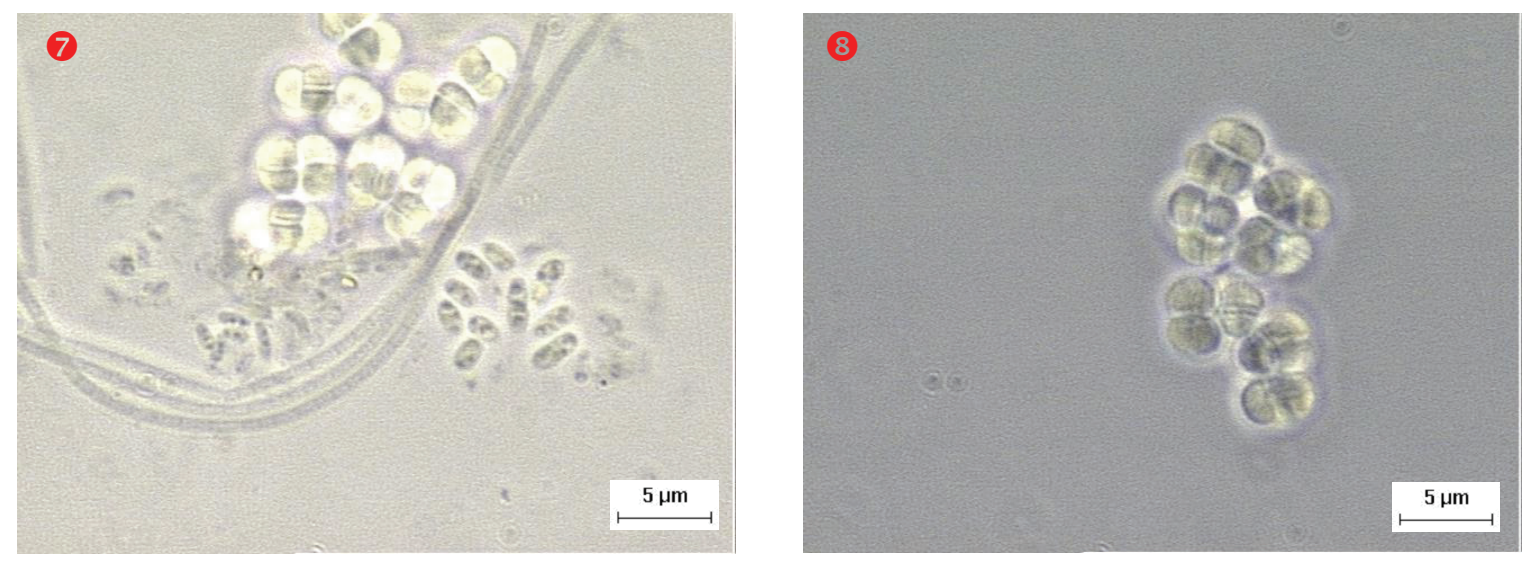

Figura 67: Morfologias encontradas no reator de biomassa suspensa na Etapa 1. (1) Cocobacilos coloniais com inclusões; (2) Filamentos e bacilos com inclusões e sem inclusões; (3) Bacilos com inclusões e cocos; (4) Aglomerado de bactérias semelhantes à 'Clusters' ANAMMOX; (5) Cocos semelhantes à nitrosococcus (maior); (6) Filamentos, bacilos com inclusões; (7) Filamentos, bacilos com inclusões e cocos em tétrade semelhantes à bactérias ' $\mathrm{G}^{\prime} ;(\mathbf{8})$ Cocos em tétrade semelhantes à bactérias ' $\mathrm{G}$ '.

Microrganismos semelhantes ao gênero Nitrosococcus foram encontrados no reator com biomassa suspensa. Estes microrganismos autotróficos são responsáveis pela oxidação de nitrogênio amoniacal em nitrito em fase aeróbia (JENKINS et al., 2003). Como na Etapa 1 verificou-se grande acúmulo de nitrito no sistema, provavelmente os microrganismos oxidadores de nitrogênio amoniacal estão em maior quantidade do que os microrganismos oxidadores de nitrito, ou as condições operacionais do reator favoreceram mais os microrganismos que produzem nitrito. Microrganismos semelhantes às nitrificante (Nitrosococcus) podem ser observados na Figura 67 (5).

Foram encontrados no reator microrganismos com a mesma morfologia e disposição das bactérias ANAMMOX. Esses microganismos são encontrados em ambientes com alta concentração de nitrito e nitrogênio amoniacal.

Encontrou-se também agrupamentos de cocos dispostos em tétrade. Esses microrganismos são semelhantes aos do gênero Tessaracoccus (MASZENAN, 1999) e Amaricoccus (MASZENAN, 1997) e estão associados à remoção de fósforo em sistemas com fases aeróbias e anóxicas alternadas e em sistemas de lodos ativados. Estes microganismos, também conhecidos como bactérias 'G' (CECH e HARTMAN, 1993 apud JENKINS et al., 2003), também são capazes de desnitrificar em ambientes anóxiicos (MASZENAN, 1999). 


\subsubsection{Microscopia ótica da ETAPA 2}

Nesta etapa foram encontrados diversas morfologias, semelhantes às da Etapa 1: cocos, bacilos, filamentos, dispostos de maneiras variadas: em colônias, em aglomerados envoltos por membrana (Clusters) e em tétrade. Observou-se em alguns microrganismos grânulos intra-celulares e também dois tipos diferentes de filamentos.
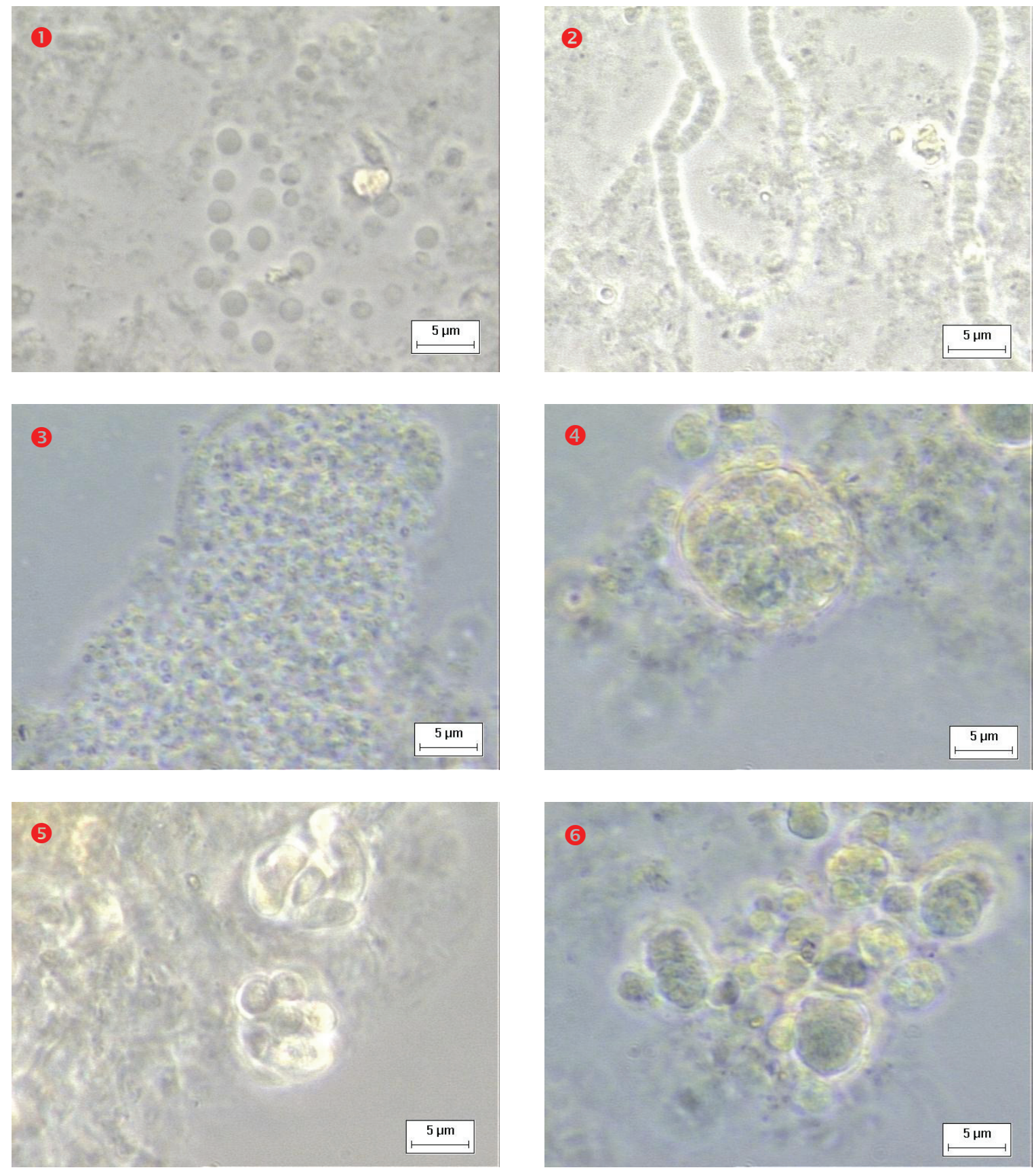

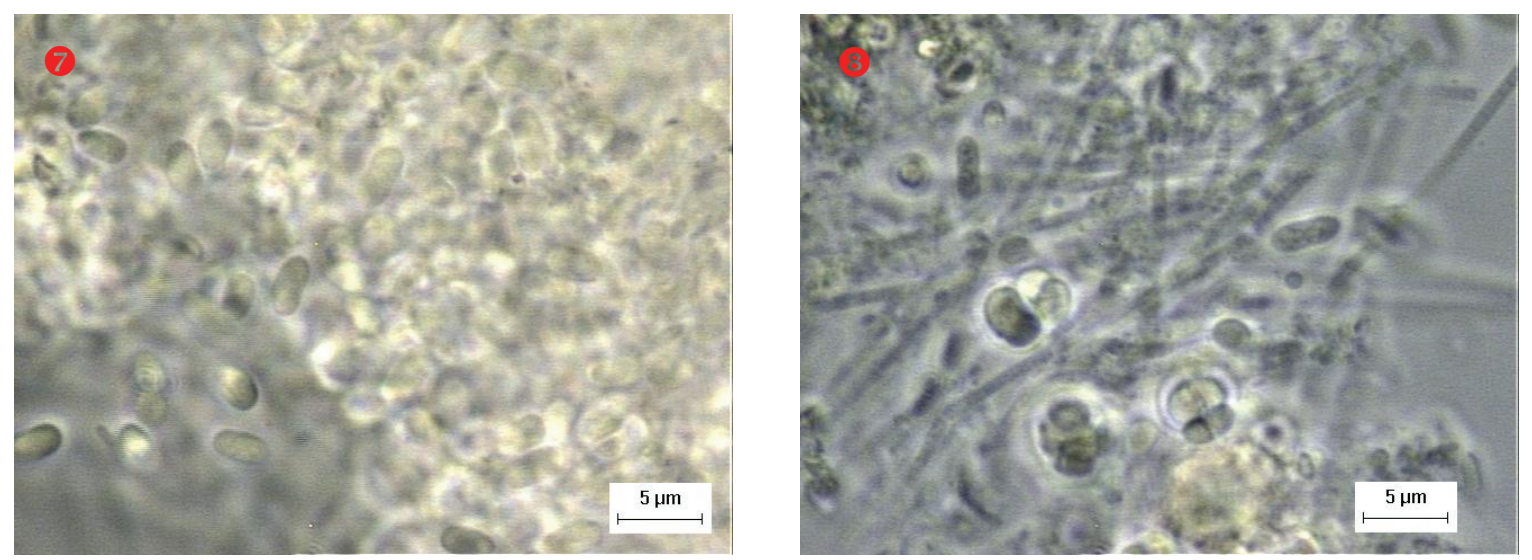

Figura 68: Microscopia óptica de contraste de fase na Etapa 2 do reator com biomassa suspensa. (1) Cocos semelhantes à nitrosococcus; (2) Filamentos com inclusões semelhantes à nostocoida limicola; (3) Cocobacilos coloniais com inclusões; (4) Aglomerado de cocos envolto por membrana semelhantes à 'Clusters' ANAMMOX; (5) Aglomerados de bacilos e cocos; (6) Aglomerado de microganismos envolto por membrana semelhantes à 'Clusters' ANAMMOX; (7) Bacilos semelhantes à bacterias fototróficas anoxigênicas; (8) Filamentos septados, bacilos com inclusões e bactérias 'G'.

Segundo Jenkins et al. (2003), Nostocoida limicola é geralmente encontrado em ambientes onde a concentração de oxigênio dissolvido é baixa. Estes microrganismos estão relacionados com a remoção de fósforo do meio, acumulando o PHB (Ácido Poly-ßhidroxibutrico).

Como na Etapa 1, encontrou-se nesta etapa microrganismos semelhantes à ANAMMOX, Nitrosococcus e Bactérias 'G'. Além destas bactérias, encontrou-se também microrganismos semelhantes às bactérias fototróficas anoxigênicas.

\subsubsection{Microscopia ótica da ETAPA 3}
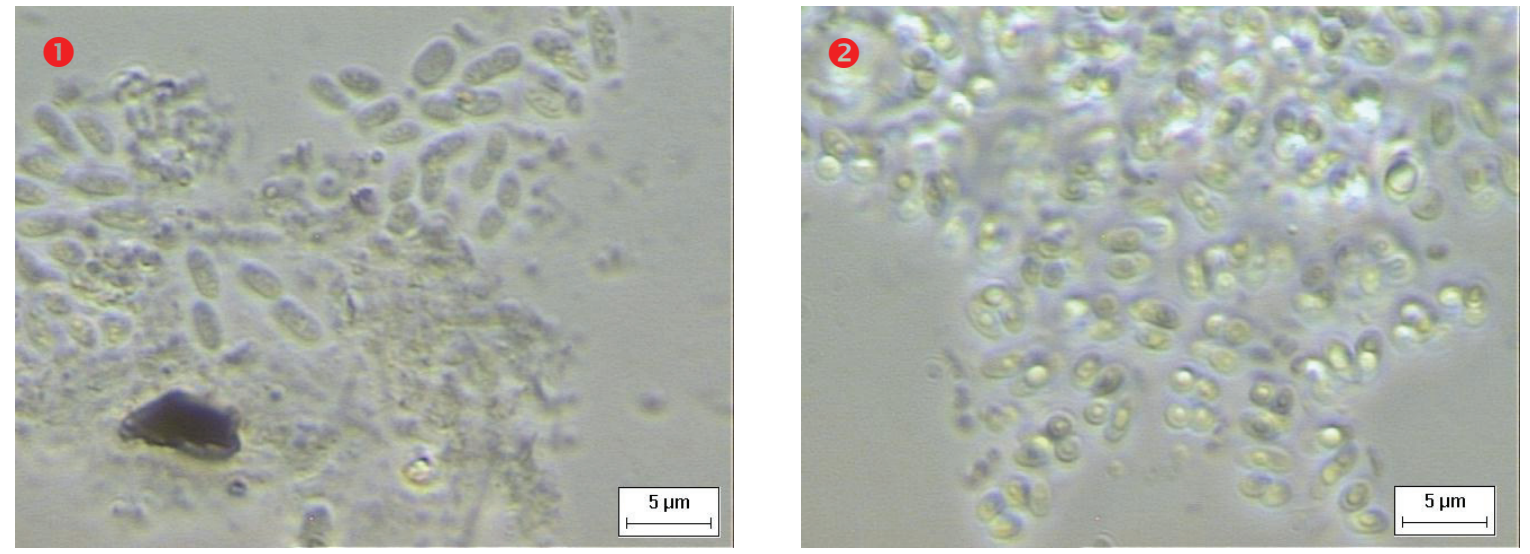

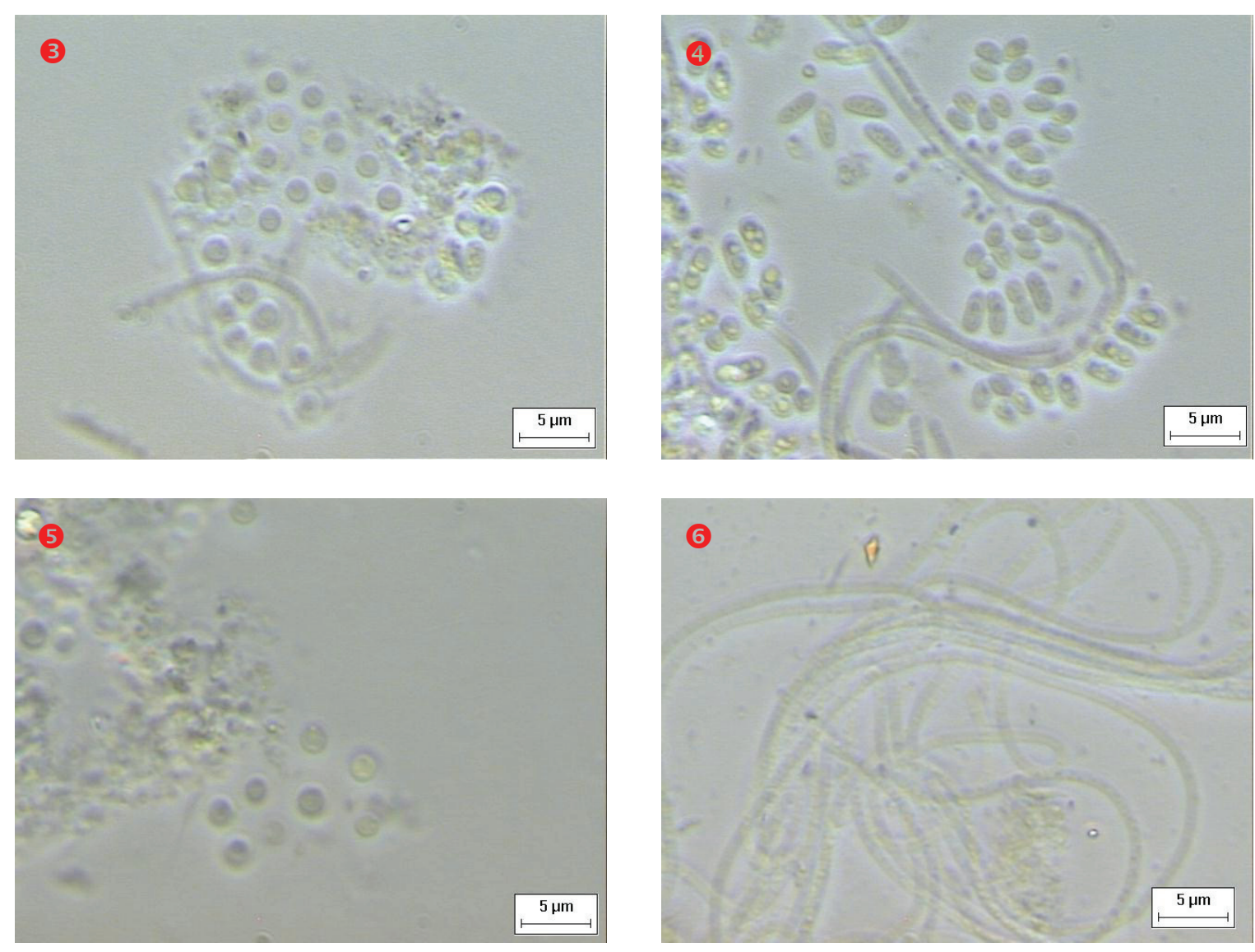

Figura 69: Microscopia óptica de contraste de fase na Etapa 3 do reator com biomassa imobilizada. (1) Bacilos com inclusões; (2) Bacilos com inclusões de enxofre; (3) Cocos semelhantes à Nitrosococcus; (4) Filamentos septados com inclusões, bacilos com inclusões diversas; (5) Cocos semelhantes à nitrosococcus; (6) Filamentos septados com inclusões semelhantes à Thiothrix.

Nesta etapa verifica-se microrganismos com dois tipos de padrões de inclusões: inclusões de pequenos grânulos (Figura 69, (1)) e inclusões com grânulos maiores (Figura 69, (2)). Segundo esses padrões, acredita-se que as inclusões com grânulos maiores sejam acúmulo intracelular de enxofre, por seus grânulos serem brilhantes visto ao microscópio, e que as pequenas inclusões sejam compostos de fósforo. No entanto, seriam necessários exames mais complexos, como EDX, para a comprovação efetiva destas observações.

Além dos microrganismos semelhantes ao gênero Nitrosococcus (Figura 69, (3) e (5)) encontra-se microrganismos com filamentos septados e com inclusões, semelhantes aos microrganismos do gênero Thiothrix (Figura 69, (4) e (6)). Segundo Jenkins et al. (2003), estes microrganismos estão associados à ambientes onde à concentração de nutrientes $(\mathrm{N}$ ou P) são limitados. Estes microrganismos também podem ser encontrados em águas contendo compostos específicos, com compostos de enxofre e/ou ácidos orgânicos, e com baixa concentração de oxigênio dissolvido. Segundo ainda os autores supracitados, esses 
microrganismos podem ser encontrados em ambientes aeróbios com elevado $\mathrm{pH}$. Os grânulos intracelulares podem ser tanto de compostos de enxofre como compostos de fósforo.

\subsubsection{Microscopia Eletrônica de Varredura da ETAPA 2}
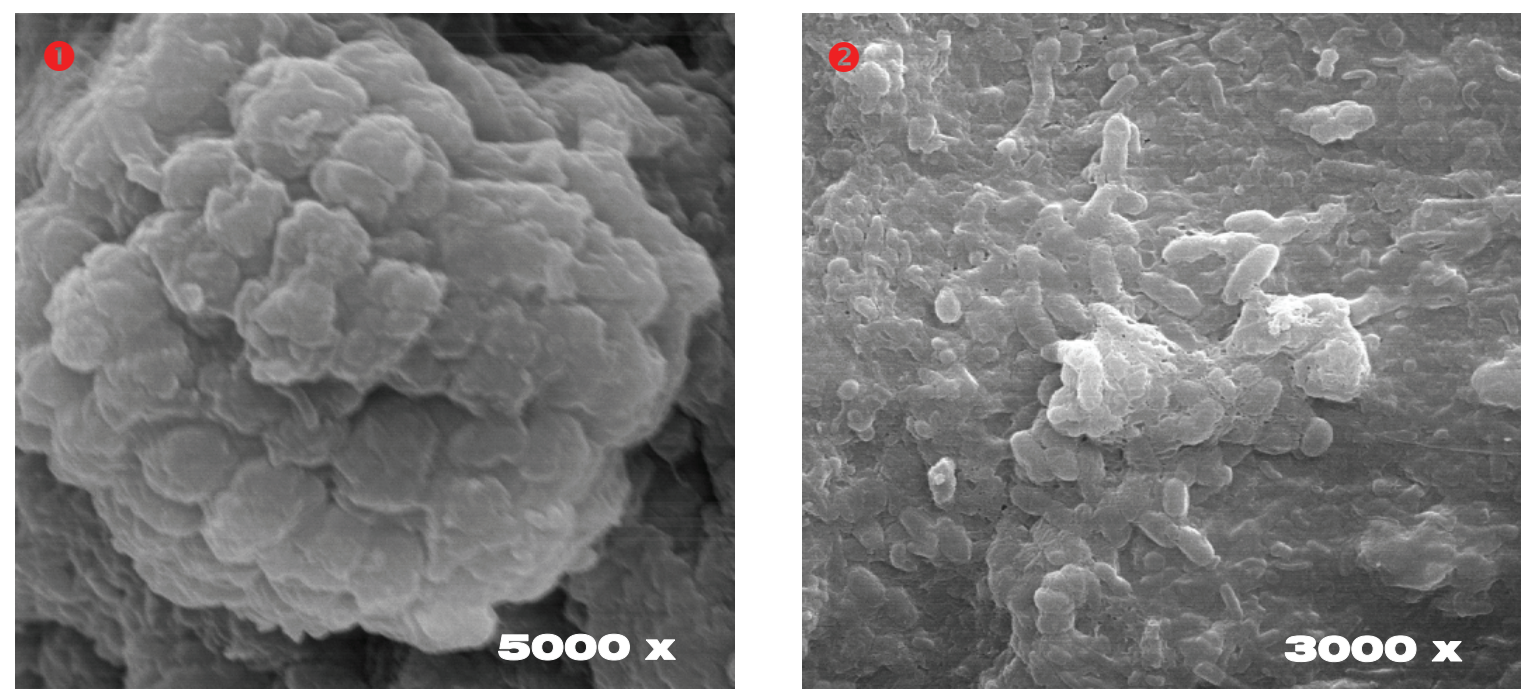

Figura 70: Microscopia eletrônica de varredura (MEV) de amostras do reator de biomassa suspensa da Etapa 2. (1) Aglomerado de cocos semelhantes às bactérias ANAMMOX; (2) Bacilos e cocos diversos.

A microscopia eletrônica de varredura (MEV) de amostra do reator de biomassa suspensa da Etapa 2, mostrou bacilos e cocos diversos (Figura 70, (2)) de diferentes tamanhos, porém o que mais chamou a atenção foi o aglomerado de cocos semelhantes aos “Clusters” ANAMMOX, mostrado na Figura 70 (1). Neste caso observa-se uma formação espacial de cocos conjugados. 


\subsubsection{Microscopia Eletrônica de Varredura da ETAPA 3}
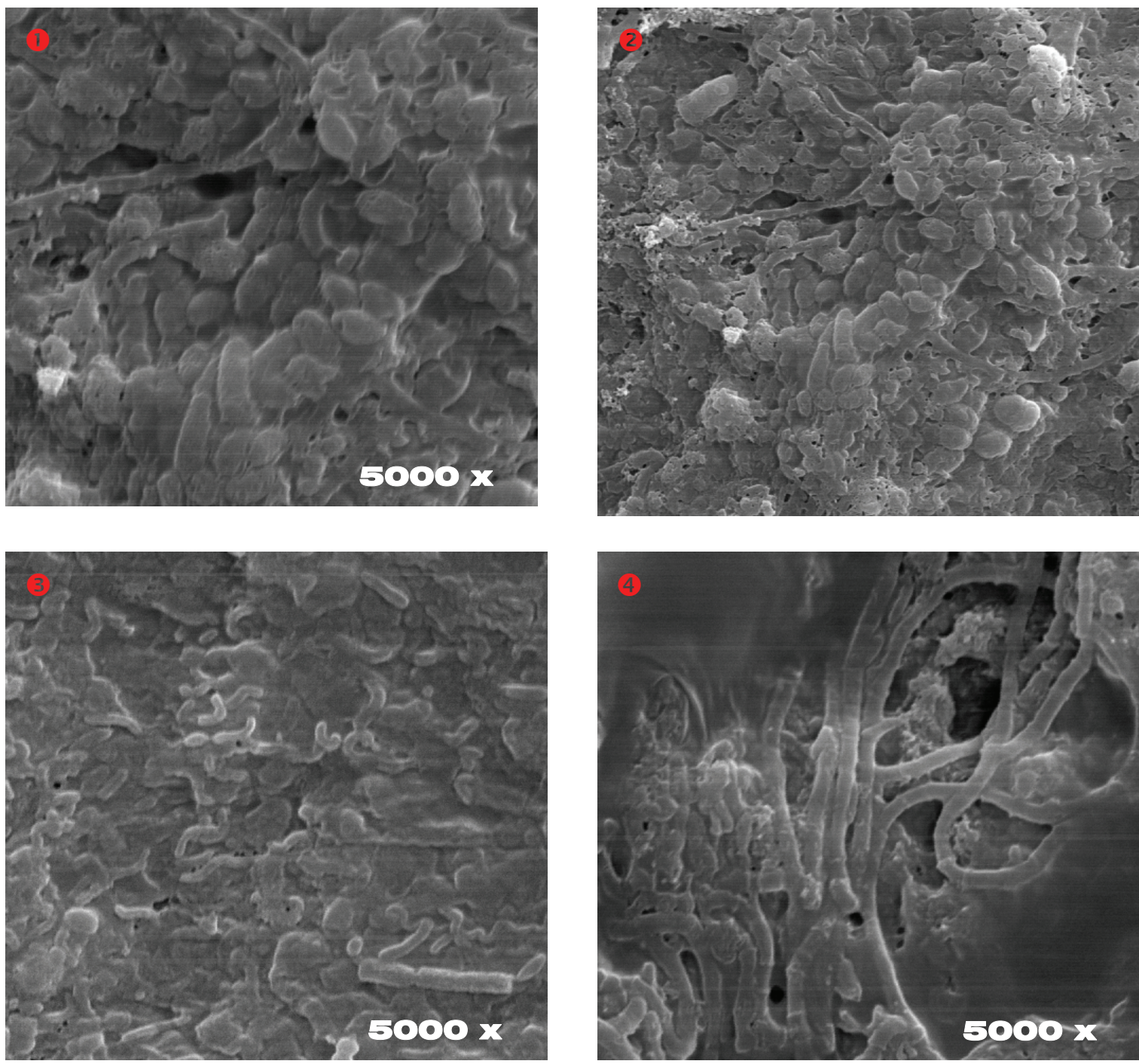

Figura 71: Microscopia eletrônica de varredura (MEV) de amostras do reator de biomassa suspensa da Etapa 2. (1) Bacilos diversos; (2) Bacilos e cocos diversos; (3) Bacilos curvos, semelhantes à BRS - Bactéria Redutora de Sulfato; (4) Filamentos septados.

$\mathrm{Na}$ microscopia eletrônica de varredura (MEV) de amostra do reator de biomassa imobilizada da Etapa 3, observa-se bacilos e cocos diversos (Figura 71, (1) e (2)). Verifica-se na Figura 71 (3) que havia bacilos curvos semelhantes à BRS (Bactérias Redutoras de Sulfato) que podem ter sido desenvolvidos nas zonas anaeróbias da estrutura do biofilme aderido. Observa-se na Figura 71 (4) filamentos septados semelhantes às bactérias do gênero Thiothrix, conforme visto na microscopia de contraste de fase da Etapa 3. 


\subsubsection{DGGE}

A avaliação de diversidades microbianas presentes nas amostras foi realizada por meio de técnicas de PCR/DGGE. Foram ensaiadas 10 amostras de diferentes lugares e condições, como mostrado na Tabela 23. As bandas B5 a B10 são de materiais biológicos que estavam presentes nos ensaios com microsensores em reator tipo célula.

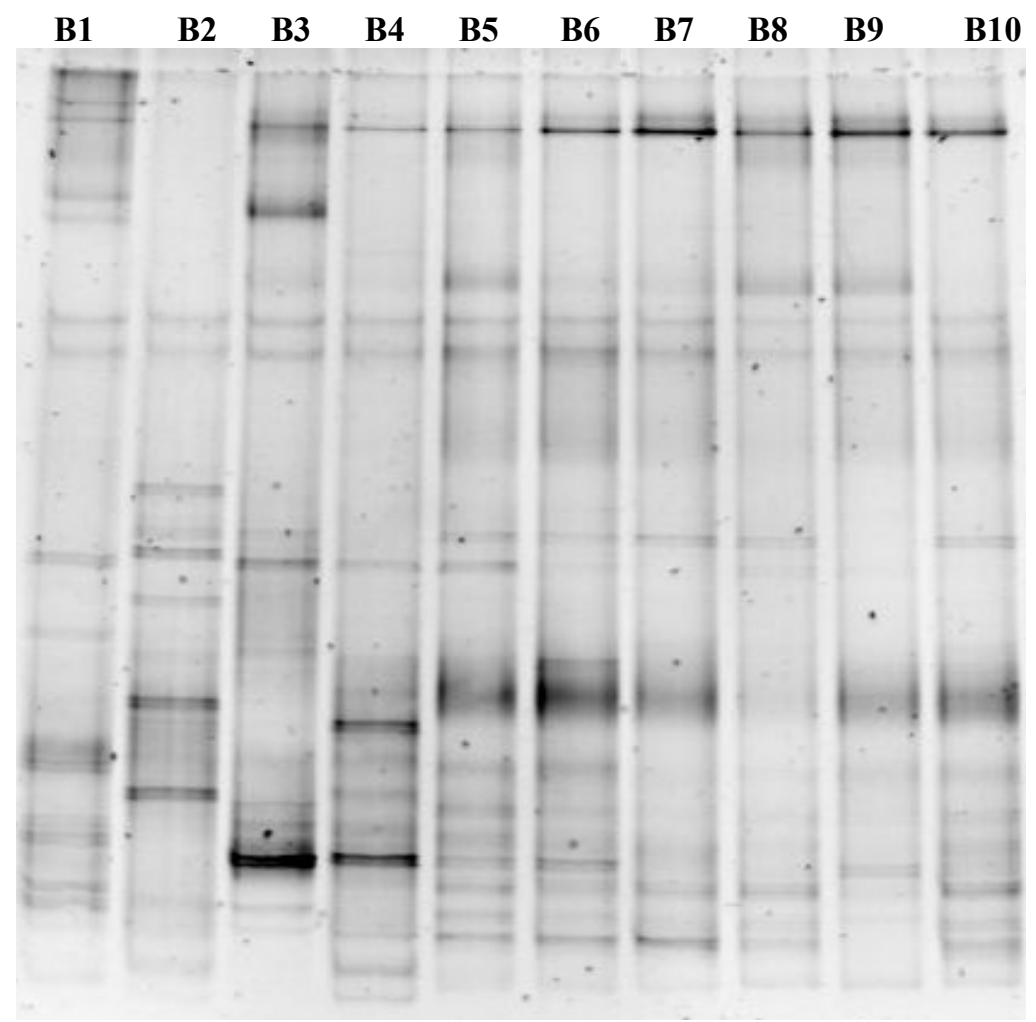

Figura 72: Fragmentos de DNA amplificados e separados por eletroforese em gel de gradiente desnaturante (DGGE).

Tabela 23: Descrição dos materiais biológicos utilizados para avaliação da comunidade microbiana em DGGE

\begin{tabular}{|c|c|c|}
\hline Banda & & Descrição \\
\hline B1 & & Reator biomassa suspensa - Etapa 2 \\
\hline B2 & & Inóculo proveniente de reator UASB de abatedouro de aves \\
\hline B3 & & Reator biomassa imobilizada - Etapa 3 \\
\hline B4 & & Grânulo do reator biomassa suspensa - Etapa 2 \\
\hline B5 & & Biomassa aderida no carvão vegetal \\
\hline B6 & Dె & Biomassa aderida no carvão mineral \\
\hline B7 & $\bar{D}$ & Biomassa aderida na espuma de poliuretano \\
\hline B8 & రิ & Biomassa aderida no disco plástico \\
\hline B9 & $\dot{z}$ & Biomassa aderida na brita basáltica \\
\hline B10 & & Biomassa aderida no polietileno de baixa densidade \\
\hline
\end{tabular}


Na comparação dos padrões das bandas do DGGE foi utilizada a equação de Gillian et al. (1998), que fornece uma aproximação da similaridade entre duas amostras isoladamente. Não foi considerada a intensidade das bandas, apenas a presença ou ausência destas. Para facilitar a comparação entre as comunidades microbianas nas diversas amostras, tabulou-se os valores de similaridade na Tabela 24.

Tabela 24: Comparação entre similaridade das comunidades microbianas (\%).

\begin{tabular}{ccccccccccc}
\hline & B1 & B2 & B3 & B4 & B5 & B6 & B7 & B8 & B9 & B10 \\
\hline B1 & 100 & - & - & - & - & - & - & - & - & - \\
B2 & 30,3 & 100 & - & - & - & - & - & - & - & - \\
B3 & 53,3 & 51,9 & 100 & - & - & - & - & - & - & - \\
B4 & 40,0 & 44,4 & 50,0 & 100 & - & - & - & - & - & - \\
B5 & 52,9 & 32,3 & 57,1 & 50,0 & 100 & - & - & - & - & - \\
B6 & 43,8 & 41,4 & 61,5 & 53,8 & 80,0 & 100 & - & - & - & - \\
B7 & 50,0 & 40,0 & 36,4 & 36,4 & 61,5 & 66,7 & 100 & - & - & - \\
B8 & 55,2 & 30,8 & 43,5 & 52,2 & 66,7 & 64,0 & 76,2 & 100 & - & - \\
B9 & 35,7 & 32,0 & 45,5 & 36,4 & 61,5 & 66,7 & 50,0 & 57,1 & 100 & - \\
B10 & 58,8 & 38,7 & 42,9 & 35,7 & 68,8 & 73,3 & 76,9 & 66,7 & 53,8 & 100 \\
\hline
\end{tabular}

Observa-se pela Tabela 24, que houve uma grande adaptação dos microrganismos nos diferentes sistemas, pois o inóculo (Banda B2) foi no máximo 51,9 \% similar à uma banda, no caso a banda B3 (reator de biomassa imobilizada).

Comparando-se a banda B1 (reator de biomassa suspensa - Etapa 2) com a banda B3 (reator de biomassa imobilizada - Etapa 3), verifica-se que a similaridade foi de apenas 53,3 $\%$, mostrando que houve o desenvolvimento de comunidades microbianas distintas em ambos os reatores, apesar das condições operacionais serem muitos semelhantes. Supõe-se que a diversidade microbiana foi maior no reator de biomassa imobilizada (Banda B3), pois o biofilme presente favorecia o surgimento de zonas anaeróbias e, conseqüentemente, o desenvolvimento de microrganimos não tolerantes à oxigênio.

No geral, não houve muita distinção entre as comunidades microbianas nos ensaios realizados em reator tipo célula utilizando diversos materiais suportes. A similaridade média foi de quase $70 \%$, atingindo, em alguns casos, uma similaridade de até $80 \%$. No entanto, alguns materiais suportes se diferenciaram fortemente: as comunidades microbianas presentes nos suportes espuma de poliuretano (Banda B7) e brita basáltica (Banda B9) tiveram uma similaridade de apenas $50 \%$ e as comunidades microbianas presentes novamente no suporte 
brita basáltica (Banda B9) e no polietileno de baixa densidade (Banda B10) tiveram uma similaridade de $53,8 \%$.

O reator de biomassa suspensa da Etapa 2 apresentava alguns grânulos inteiros que eram possivelmente grânulos do inóculo (lodo granular de reator UASB) que não se desfizeram no processo de aeração do reator. Pelo que consta na Tabela 24, o grau de similaridade entre esses grânulos (Banda B4) e o lodo de inóculo (Banda B2) foi muito baixa, aproximadamente 44\%, indicando uma adaptação dos grânulos às condições impostas no reator.

Observa-se, portanto que apesar das condições operacionais serem semelhantes, houve uma diversificação das comunidades microbianas, provavelmente devido à diferenciação na estrutura do biofilme.

\subsection{COMENTÁRIOS GERAIS}

\subsubsection{Acúmulo de nitrito em sistema nitrificante}

Um fato que merece atenção nos resultados foi o acúmulo de nitrito no sistema. Com a estratégia de operação de 24 horas com 4 fases alternadas, aeróbias e anóxicas (Etapa 1) verificou-se o acúmulo de nitrito nas fases aeróbias. As concentrações de nitrato e de nitrito foram aproximadamente iguais. Após a reinoculação (estratégia de operação de 12 horas de ciclo com fase aeróbia e anóxica) e a respectiva diminuição de biomassa do sistema (Etapa 2) e no reator com biomassa imobilizada (Etapa 3), nota-se que o produto principal da nitrificação foi nitrito, sendo o nitrato despresível em relação à concentração de nitrito. Observou-se um comportamento semelhante no reator com biomassa imobilizada.

A diferença de sensibilidade dos microrganismos nitritantes e nitratantes à diversos fatores ambientais, como oxigênio dissolvido, temperatura, $\mathrm{pH}$, amônia livre e óxido nitroso livre, determina o acúmulo de nitrito no meio, indicando que os microrganismos nitratantes são mais sensíveis que os microrganismos nitritante (PHILIPS, LAANBROEK e VERSTRAETE, 2002).

Segundo Anthonisen et al. (1976) a amônia livre e o óxido nitroso livre são as principais causas para acúmulo de nitrito no sistema. Esses autores desenvolveram gráfico com dependência da concentração de amônia total e nitrito em função do $\mathrm{pH}$. O gráfico mostrado na Figura 73, é dividido em zonas de inibição. A Zona $1\left(\mathrm{NH}_{3}>10-150 \mathrm{mgN}\right.$ $\left.\mathrm{NH}_{3} \cdot l^{-1}\right)$ representa a inibição total da nitrificação, na qual os microrganismos oxidadores de 
nitrogênio amoniacal e nitrito são inibidos. $\mathrm{Na}$ Zona $2\left(0,1-1,0 \mathrm{mgN}-\mathrm{NH}_{3} . l^{-1}<\mathrm{NH}_{3}<10-150\right.$ $\left.\mathrm{mgN}-\mathrm{NH}_{3} \cdot l^{-1}\right)$ a amônia livre apenas inibe os microrganismos oxidadores de nitrito, tendo como conseqüência o acúmulo de nitrito no meio. Na Zona $3\left(\mathrm{NH}_{3}<0,1-1,0 \mathrm{mgN}-\mathrm{NH}_{3} . l^{-1} \mathrm{e}\right.$ $\mathrm{HNO}_{2}<0,2-2,8 \mathrm{mgN}-\mathrm{HNO}_{2} \cdot l^{-1}$ ), não há nenhum tipo de inibição dos microrganismos nitrificantes, e na Zona 4, os microrganismos oxidadores de nitrito são inibidos pelo ácido nitroso livre $\left(\mathrm{HNO}_{2}>0,2-2,8 \mathrm{mgN}-\mathrm{HNO}_{2} \cdot l^{-1}\right)$, obtendo como resultado o acúmulo de nitrito.

O acúmulo de nitrito nos sistemas de biomassa suspensa e imobilizada encontrado nesta pesquisa pode ser devido à inibição por amônia livre e óxido nitroso livre. Como a concentração desses compostos inibidores depende do $\mathrm{pH}$ do meio, a amônia livre é o principal responsável pela inibição, quando o $\mathrm{pH}$ é maior do que $8(\mathrm{pH}>8)$. Já para $\mathrm{pH}<7,5$, o ácido nitroso livre é o principal inibidor em sistemas nitrificantes. Como o afluente dos sistemas eram alcalinizados, o pH afluente era superior à 7,5. No sistema, o pH geralmente subia, chegando, em alguns casos, próximo a 9. Portanto atribui-se a inibição dos microrganismos que oxidam nitrito principalmente por amônia livre no sistema.

No sistema com biomassa suspensa com estratégia de 24 horas de ciclo com 4 fases alternadas, observa-se que o produto da nitrificação era nitrato e nitrito em proporções semelhantes, indicando que o sistema estava em uma zona intermediária entre a zona de inibição dos microrganismos nitratantes (Zona2) e a zona de não inibição (Zona3). Já após a reinoculação do sistema de biomassa suspensa e no sistema de biomassa imobilizada, observou-se a permanência na Zona2, pois houve acúmulo de nitrito e o nitrato presente era insignificativo.

Anthonisen et al. (1976) verificaram os limites inibitórios em um sistema de biomassa suspensa; no entanto, é preciso ter ressalvas na aplicação destas faixas inibitórias, pois não são consideradas a estrutura do biofilme nem a configuração do reator. Prakasam e Loehr (1972) observaram que a concentração de $0,02 \mathrm{mgN}-\mathrm{HNO}_{2} . l^{1}$ era o valor mínimo para a ocorrência da inibição por óxido nitroso livre. Este valor está bem abaixo do encontrado por Anthonisen et al. (1976). 


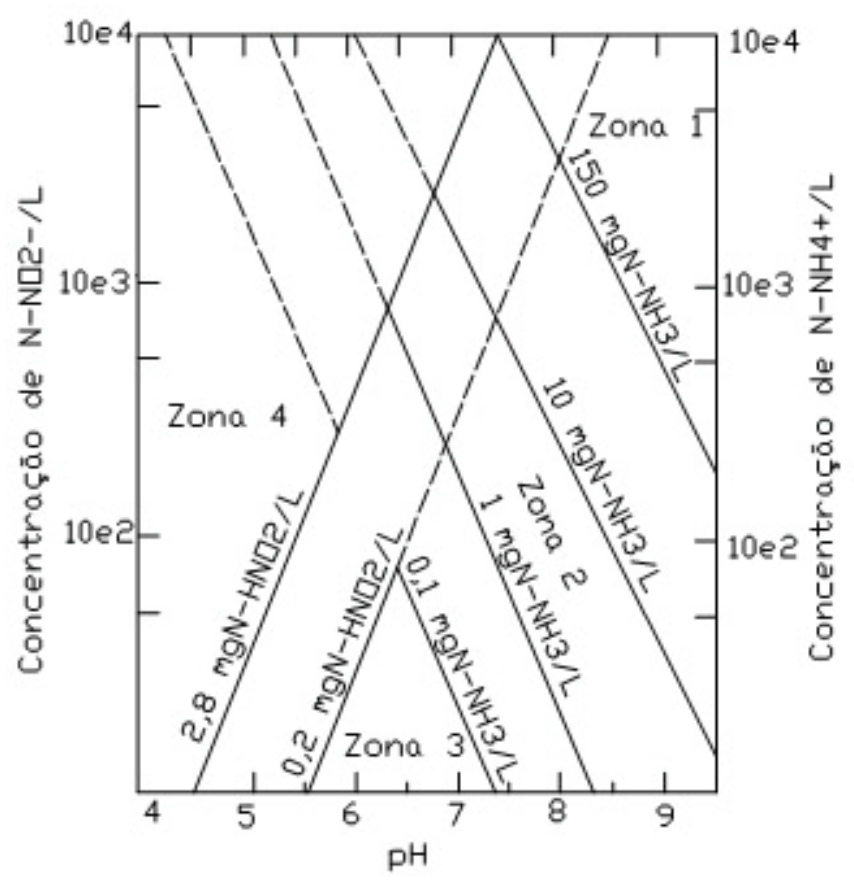

Figura 73: Relação entre a concentração de amônia e ácido nitroso e a inibição à bactérias nitrificantes adaptado de Anthonisen et al. (1976).

Para muitos autores, o oxigênio dissolvido é considerado um dos principais fatores limitantes da nitrificação. Segundo Philips et al. (2002), a deficiência de oxigênio é mais prejudicial para as bactérias nitratantes do que para as bactérias nitritantes. No entanto, nos experimentos realizados, mesmo na presença de uma elevada aeração (8 a 9 L-Ar.min ${ }^{-1}$ ), verificou-se que houve o acúmulo de nitrito.

Yang e Alleman (1992), operaram um sistema nitrificante em batelada, com concentração de oxigênio de $0,5 \mathrm{mgO}_{2} \cdot l^{-1}$ e $\mathrm{pH}$ médio de 7,5 e constataram que houve acúmulo de hidroxilamina $\left(\mathrm{NH}_{2} \mathrm{OH}\right)$ e a nitratação foi inibida com o conseqüente acúmulo de nitrito. Os autores atribuíram a inibição da nitratação pela hidroxilamina e não pela deficiência de oxigênio. Fux e colaboradores (2003) observaram o acúmulo de nitrito por inibição dos microrganismos que oxidam nitrito por baixas concentrações de hidroxilamina (1 $\left.\operatorname{mg} . l^{-1}\right)$.

O acúmulo de nitrito no sistema operado pode ser também devido a inibição por hidroxilamina aos microrganismos nitratantes. Como não foi medido este intermediário da nitrificação $\left(\mathrm{NH}_{2} \mathrm{OH}\right)$, não se pode afirmar este fenômeno, porém pode ser uma hipótese para tal fato. 


\subsubsection{Desnitrificação em fase aeróbia}

Nos experimentos realizados, foi verificada a atividade desnitrificante que, em muitos casos, superou 30\% da remoção total de nitrogênio. Em teste de "stripping" (Figura 66) realizado, a perda de nitrogênio amoniacal máxima em condições críticas de elevada aeração (8 a $9{\left.\mathrm{~L} \cdot \mathrm{min}^{-1}\right)}^{-1}$ e elevado $\mathrm{pH}(9$ a 9,6), não foi superior à $10 \%$. Sem dúvida, a remoção elevada de nitrogênio em fase aeróbia é um fato que merece atenção.

Remoção dessa magnitude em fase aeróbia é frequentemente encontrada em reator biológico para remoção de nitrogênio e lodos ativados em escala plena (U. S. EPA, 1987; RANDALL et al., 1992). Atribui-se este fenômeno devido a desnitrificação em microzonas anóxicas no interior do floco.

Pochana e Keller (1999) obersaram que, para altas concentrações de oxigênio no meio líquido, a desnitrificação é inibida, causando o acúmulo de nitrato e nitrito. Em experimento em batelada para remoção de nitrogênio, para baixas concentrações de oxigênio dissolvido ( 0,3 a $\left.0,8 \mathrm{mgO}_{2} \cdot l^{-1}\right)$, observaram uma diminuição da atividade nitrificante e a manifestação da atividade desnitrificante. Para os autores, o oxigênio dissolvido é o principal fator para o processo de nitrificação e desnitrificação simultânea (SND - Simultaneous Nitrification and Denitrification).

Segundo Von Münch et al. (1996), a nitrificação e a desnitrificação simultânea só ocorre com uma concentração de oxigênio abaixo de $0,5 \mathrm{mgO}_{2} \cdot l^{-1}$, ou seja, a desnitrificação pode ocorrer em zonas microaeróbias.

No sistema operado nesta pesquisa, com a estratégia de operação de 24 horas e 4 fases alternandas, observou-se a ocorrência da desnitrificação na fase aeróbia, tanto na presença de ácidos orgânicos quanto na ausência destes. Na ausência de matéria orgânica prontamente degradável, a desnitrificação se deve provavelmente à desnitrificação endógena, mesmo em fase aeróbia. Puznava, Payraudeau e Thornberg (2001) verificaram a nitrificação e a desnitrificação simultânea sem a adição de fonte de carbono e atingiram eficiências de até $70 \%$ em um filtro aeróbio que tratava água residuária sintética e variaram a concentração de nitrogênio amoniacal de 30 a $80 \mathrm{mgN}-\mathrm{NH}_{4}{ }^{+} \cdot l^{-1}$ e de oxigênio dissolvido de 0,5 a $3,0 \mathrm{mgO}_{2} \cdot l^{-1}$. 


\subsubsection{Desnitrificação endógena}

$\mathrm{Na}$ primeira etapa do experimento (verificação da desnitrificação endógena) encontrou-se resultados que superaram as expectativas. A eficiência média de remoção de nitrogêio nestes experimentos foi de $65 \pm 27 \%$ e em alguns casos chegou ser superior à $90 \%$. Neste tópico serão discutidas hipóteses para tentar elucidar elevadas remoções de nitrogênio.

Vocks et al. (2005) investigaram a desnitrificação combinada com a remoção de fósforo em um reator biológico de membrana sem a adição de fontes externas de carbono. Os autores encontraram uma velocidade de desnitrificação muito elevada e evidenciaram que a lise celular não contribuía de forma efetiva para o processo desnitrificante. O glicogênio, acumulado durante a fase aeróbia por organismos acumuladores de glicogênio (GAO Glycogen Accumulating Organisms) é posteriormente consumido na fase anóxica para o processo desnitrificante.

Segundo Mino et al. (1998) e Sudiana et al. (1999) fases alternadas aeróbias/anóxicas favorecem o desenvolvimento, entre outros, de microrganismos acumuladores de fósforo (PAO - Polyphosphate Accumulating Organisms) e microganismos acumuladores de glicogênio (GAO). Os microrganismos acumuladores de fósforo são capazes de acumular intracelularmente polifosfato em fase aeróbia, levando à remoção de fósforo do meio líquido. Em fase anaeróbia, esses microrganismos podem utilizar os ácidos voláteis do meio para formação intracelular de PHAs (poly-b-hidroxialcanoatos), liberando o fosfato novamente para o meio líquido.

No entanto, na presença de compostos oxidados de nitrogênio, os microrganismos acumuladores de fósforo (PAOs) utilizam o nitrato e nitrito como aceptores de elétrons, no lugar do oxigênio, levando ao acúmulo de polifosfatos intracelularmente e à desnitrificação simultaneamente (OEHMEN et al., 2007). Neste caso, o processo de acúmulo de fosfato é aproximadamente $40 \%$ menor do que na presença de oxigênio. Esse processo combinado pode ser interessante, pois diminui recursos com aeração e diminui ou até mesmo pode suprimir a adição de fontes de carbono no processo desnitrificante, tornado este processo muito atrativo (KUBA et al., 1996).

Infelizmente, no experimento realizado não foram medidas as concentrações de fósforo e glicogênio no meio. No entanto, foram encontrados microrganismos que continham grânulos intracelulares e bactérias similares às bactérias acumuladoras de glicogênio, chamadas de bactérias "G", semelhantes aos encontrados no reator submetido em condições 
alternadas aeróbias/anóxicas operado por Iamamoto (2005). As microscopias destes microrganismos são apresentadas na Figura 67 (7) e (8) e na Figura 68 (8).

A utilização dos microrganismos acumuladores de fósforo e glicogênio apresenta um grande potencial na remoção de nutrientes de águas residuárias em sistemas alternados aeróbios/anóxico, pois reduz significamente custos ao sistema de tratamento. No entanto, é necessário um maior conhecimento dos microrganismos envolvidos a fim de otimizar o tratamento terciário combinado para remoção de fósforo e nitrogênio. A remoção fósforo não foi contemplada neste estudo, porém, fica evidente a necessidade da verificação desse composto quando se alterna fases aeróbias/anóxicas.

São necessários ensaios mais específicos para comprovar a origem da fonte de carbono para o processo desnitrificante, porém a desnitrificação endógena que utiliza compostos que são de difícil biodegradação não está descartada. Os principais materiais orgânicos que são utilizados para esta desnitrificação são restos celares e polímeros extracelulares excretados por bactérias. Esses compostos são hidrolizados e transformados em substratos de fácil degradação utilizados pelos microrganismos desnitrificantes (CARUCCI et al., 1996).

A velocidade de desnitrificação utilizando compostos de fácil assimilação é na ordem de 3,5 vezes maior do que a desnitrificação endógena (CARUCCI et al., 1996; HENZE et al. (1994); EKEMA e MARAIS (1984) apud CARUCCI et al., 1996). No entanto a desnitrificação endógena pela lise ou hidrólise do lodo pode ser uma alternativa interessante, visto que não é necessária a utilização de fontes exógenas de carbono para o processo desnitrificante.

\subsubsection{Ocorrência de processos não convencionais de remoção de nitrogênio}

Nos experimentos realizados nesta pesquisa, ficou evidenciado que, em muitos casos, através da modelagem dos dados experimentais, houve a remoção de nitrogênio amoniacal em fase anóxica. A remoção de nitrogênio amoniacal chegou a $23 \mathrm{mgN}-\mathrm{NH}_{4}{ }^{+} \cdot l^{-1}$ e pode ser atribuída à processos não convencionais de remoção de nitrogênio, como o processo ANAMMOX e o SURAMMOX.

O processo ANAMMOX é um processo autotrófico e não necessita de fontes de carbono orgânico para a redução de nitrito (VAN DE GRAAF et al., 1996). Experimentos realizados por van de Graff et al. (1996) mostraram que compostos orgânicos como acetato, glicose e piruvato têm efeitos prejudiciais sobre a atividade ANAMMOX. Porém, Pathak et 
al. (2007), verificaram, através de técnicas de hibridação fluorescente in situ (FISH Fluorescence In Situ Hybridization) e através de técnicas de carbono marcado, a ocorrência do processo ANAMMOX e a desnitrificação convencional, com baixas concentrações de nitrogênio amoniacal na presença de matéria orgânica. Sumino et al. (2006) também evidenciaram a ocorrência do processo ANAMMOX concomitantemente com o processo de desnitrificação heterotrófica, utilizando acetato como fonte de carbono.

Atualmente não há muita informação sobre o processo não convencional de remoção de nitrogênio SURAMOX. Teoricamente este é um processo autotrófico que utiliza o nitrogênio amoniacal como fonte de energia inorgânica para redução de sulfato à enxofre elementar. Este processo é extremamente particular, pois apenas é viável se o sulfato se transformar em $S^{0}$ e o nitrogênio amoniacal passar diretamente para $\mathrm{N}_{2}$, não adimitindo intermediários, conforme pode ser visto na seqüência de reações descritas na Tabela 25.

Para a ocorrência do processo SURAMOX seria necessário um meio extremamente adaptado e em condições de desenvolver a cultura autotrófica, ou seja, sem a presença de matéria orgânica e com fonte inorgânica de carbono. A presença de matéria orgânica provavelmente inibiria esse processo, pois o processo SURAMOX tem uma energia livre muito pequena.

Uma alternativa para que este processo ocorresse seria através do deslocamento químico de intermediários da reação. Seria necessário que todo e qualquer intermediário da reação fosse removido do sistema para que a reação, mesmo termodinamicamente desfavorável, ocorresse, indicando a necessidade obrigatória de outros processos concomitantemente como, por exemplo, a desnitrificação autotrófica, utilizando compostos oxidados de nitrogênio $\left(\mathrm{NO}_{3}{ }^{-}\right.$e $\left.\mathrm{NO}_{2}{ }^{-}\right)$e compostos reduzidos de enxofre $\left(\mathrm{H}_{2} \mathrm{~S}, \mathrm{HS}^{-}\right.$e $\left.\mathrm{S}_{2}{ }^{-}\right)$ como fontes de energia. Só assim o processo SURAMOX seria viabilizado. 
Tabela 25: Reações teóricas do processo SURAMOX.

\begin{tabular}{|c|c|c|c|}
\hline $\mathrm{N}^{\circ}$ & Reação & $\Delta \mathrm{G}(\mathrm{kJ})$ & Produtos Finais \\
\hline 1 & $2 \mathrm{NH}_{4}^{+}+\mathrm{SO}_{4}^{-2} \rightarrow \mathrm{N}_{2}+\mathrm{S}+4 \mathrm{H}_{2} \mathrm{O}$ & -45 & $\mathrm{~N}_{2} / \mathrm{S}$ \\
\hline 2 & $8 \mathrm{NH}_{4}^{+}+3 \mathrm{SO}_{4}^{-2} \rightarrow 4 \mathrm{~N}_{2}+2 \mathrm{H}^{+}+3 \mathrm{H}_{2} \mathrm{~S}+12 \mathrm{H}_{2} \mathrm{O}$ & +58 & $\mathrm{~N}_{2} / \mathrm{H}_{2} \mathrm{~S}$ \\
\hline 3 & $8 \mathrm{NH}_{4}^{+}+3 \mathrm{SO}_{4}^{-2} \rightarrow 4 \mathrm{~N}_{2}+5 \mathrm{H}^{+}+3 \mathrm{HS}^{-}+12 \mathrm{H}_{2} \mathrm{O}$ & +63 & $\mathrm{~N}_{2} / \mathrm{HS}^{-}$ \\
\hline 4 & $8 \mathrm{NH}_{4}^{+}+3 \mathrm{SO}_{4}^{-2} \rightarrow 4 \mathrm{~N}_{2}+8 \mathrm{H}^{+}+3 \mathrm{~S}^{-2}+12 \mathrm{H}_{2} \mathrm{O}$ & +258 & $\mathrm{~N}_{2} / \mathrm{S}^{-}$ \\
\hline 5 & $2 \mathrm{NH}_{4}^{+}+3 \mathrm{SO}_{4}^{-2} \rightarrow \mathrm{N}_{2}+2 \mathrm{H}^{+}+3 \mathrm{SO}^{-2}+3 \mathrm{H}_{2} \mathrm{O}$ & +698 & $\mathrm{~N}_{2} / \mathrm{SO}_{3}^{-2}$ \\
\hline 6 & $\mathrm{NH}_{4}^{+}+\mathrm{SO}_{4}-2 \rightarrow \mathrm{NO}^{2-}+\mathrm{S}+2 \mathrm{H}_{2} \mathrm{O}$ & +315 & $\mathrm{NO}_{2}^{-} / \mathrm{S}$ \\
\hline 7 & $3 \mathrm{NH}_{4}^{+}+4 \mathrm{SO}_{4}^{-2}+2 \mathrm{H}^{+} \rightarrow 3 \mathrm{NO}^{3-}+4 \mathrm{~S}+7 \mathrm{H}_{2} \mathrm{O}$ & +1225 & $\mathrm{NO}_{3}{ }^{-} / \mathrm{S}$ \\
\hline 8 & $\mathrm{NH}_{4}^{+}+\mathrm{SO}_{4}^{-2} \rightarrow \mathrm{NO}^{3-}+\mathrm{H}_{2} \mathrm{~S}+\mathrm{H}_{2} \mathrm{O}$ & +449 & $\mathrm{NO}_{3}^{-} / \mathrm{H}_{2} \mathrm{~S}$ \\
\hline 9 & $\mathrm{NH}_{4}^{+}+\mathrm{SO}_{4}^{-2} \rightarrow \mathrm{NO}^{3-}+\mathrm{H}^{+}+\mathrm{HS}^{-}+\mathrm{H}_{2} \mathrm{O}$ & +489 & $\mathrm{NO}_{3}^{-} / \mathrm{HS}^{-}$ \\
\hline 10 & $4 \mathrm{NH}_{4}^{+}+3 \mathrm{SO}_{4}^{-2} \rightarrow 4 \mathrm{NO}^{2-}+5 \mathrm{H}^{+}+3 \mathrm{HS}^{-}+4 \mathrm{H}_{2} \mathrm{O}$ & +1503 & $\mathrm{NO}_{2}^{-} / \mathrm{HS}^{-}$ \\
\hline 11 & $\mathrm{NH}_{4}^{+}+\mathrm{SO}_{4}^{-2} \rightarrow \mathrm{NO}^{3-}+2 \mathrm{H}^{+}+\mathrm{S}^{-2}+\mathrm{H}_{2} \mathrm{O}$ & +560 & $\mathrm{NO}_{3}^{-} / \mathrm{S}^{-}$ \\
\hline 12 & $4 \mathrm{NH}_{4}^{+}+3 \mathrm{SO}_{4}^{-2} \rightarrow 4 \mathrm{NO} 2-+8 \mathrm{H}^{+}+3 \mathrm{~S}^{-2}+4 \mathrm{H}_{2} \mathrm{O}$ & +1716 & $\mathrm{NO}_{2}^{-} / \mathrm{S}_{2}^{-}$ \\
\hline 13 & $\mathrm{NH}_{4}^{+}+3 \mathrm{SO}_{4}^{-2} \rightarrow \mathrm{NO}^{2-}+2 \mathrm{H}^{+}+3 \mathrm{SO}^{-2}+\mathrm{H}_{2} \mathrm{O}$ & +1058 & $\mathrm{NO}_{2}^{-} / \mathrm{SO}_{3}^{-2}$ \\
\hline 14 & $\mathrm{NH}_{4}^{+}+4 \mathrm{SO}_{4}^{-2} \rightarrow \mathrm{NO}^{3-}+2 \mathrm{H}^{+}+4 \mathrm{SO}^{-2}+\mathrm{H}_{2} \mathrm{O}$ & +1399 & $\mathrm{NO}_{3}^{-} / \mathrm{SO}_{3}^{-2}$ \\
\hline
\end{tabular}

A energia livre de Gibs $(\Delta \mathrm{G})$ teórica para o processo ANAMMOX é de $-360 \mathrm{~kJ}$ e para o processo SURAMOX é de $-45 \mathrm{~kJ}$, indicando que o processo de oxidação do nitrogênio amoniacal utilizando o nitrito é mais favorável do que utilizando o sulfato e que, provavelmente, o processo ANAMMOX prevalece sobre o SURAMOX.

A aeração, nas fases aeróbias do reator, poderia inibir reversivelmente as bactérias ANAMMOX (JETTEN et al., 2003; GUT et al., 2007). No entanto, as condições do reator eram propícias ao desenvolvimento desta cultura, pois havia uma alta concentração de nitrogênio amoniacal e nitrito na fase anóxica para a ocorrência de tal processo. Além deste fato, foram encontrados microrganismos alocados em clusters (aglomerados) semelhantes aos microrganismos ANAMMOX, como visto na Figura 67 (4), Figura 68 (4) e (6) e Figura 70 (1).

Apesar das constatações encontradas, é difícil imputar isoladamente fenômenos em um sistema com uma biodiversidade complexa como neste reator aeróbio/anóxico. A constatação de processos não convencionais para remoção de nitrogênio amoniacal em fase anóxica pode ser atribuída majoritariamente ao processo ANAMMOX, pois através das reações teóricas dos possíveis intermediários do processo SURAMOX ficou clara a dificuldade da ocorrência deste processo. 


\subsubsection{Utilização de compostos de enxofre para o processo de desnitrificação autotrófica}

Nos experimentos realizados foi encontrada a remoção simultânea de nitrito $\left(\mathrm{NO}_{2}{ }^{-}\right)$e sulfeto $\left(\mathrm{S}^{2-}\right)$ e observou-se também que todo sulfito $\left(\mathrm{SO}_{3}{ }^{-2}\right)$ injetado no sistema na fase anóxica, na presença de compostos oxidados de nitrogênio, foi totalmente consumido, indicando a ocorrência da desnitrificação autotrófica. Para muitos autores esse é um processo viável e uma alternativa interessante para o processo de denitrificação heterotrófica, pois, segundo Zhang e Lampe (1999), não é necessário utilizar fontes exógenas de carbono, como etanol e metanol, para o processo autotrófico de desnitrificação e o crescimento da biomassa desnitrificante é menor, minimizando custos globais de operação e manutenção dos sistemas desnitrificantes.

Além do sulfeto $\left(\mathrm{S}^{2-}\right)$, outros compostos de enxofre como o gás sulfídrico $\left(\mathrm{H}_{2} \mathrm{~S}\right)$, o sulfeto de hidrogênio (HS $)$, o tiossulfato $\left(\mathrm{S}_{2} \mathrm{O}_{3}{ }^{-2}\right)$, o tiossulfito $\left(\mathrm{S}_{2} \mathrm{O}_{2}{ }^{-2}\right)$, o sulfito $\left(\mathrm{SO}_{3}{ }^{-2}\right)$ e até mesmo o enxofre elementar $\left(\mathrm{S}^{0}\right)$, podem servir como doadores de elétrons para o processo de desnitrificação autotrófica, utilizando fontes inorgânicas de carbono, como gás carbônico $\left(\mathrm{CO}_{2}\right)$ e bicarbonato $\left(\mathrm{HCO}_{3}{ }^{-}\right)$, para manutenção celular e crescimento (KLEEREBEZEM e MÉNDEZ (2002); KRISHNAKUMAR e MANILAL (1999); TROUVE et al. (1998); FURUMAI et al. (1996); KIMURA et al. (2002); SOARES (2002)).

Devido à limitações técnicas foi possível apenas realizar ensaios dos compostos de enxofre como sulfeto, sulfito e sulfato. Análises de compostos como enxofre elementar, tiossulfato e tiossulfito não foram realizadas.

Apesar da realização da análise de sulfato, esta não pode ser conclusiva devido à erros metodológicos inerentes à própria análise. Métodos analíticos mais precisos são necessários para o estudo da desnitrificação autotrófica utilizando compostos de enxofre, para ser possível identificar pequenas variações que muitas vezes são imperceptíveis visualmente. 


\section{Capítulo 5}

\section{Conclusões}

\subsection{CONCLUSÕES}

Os resultados obtidos com os reatores de biomassa suspensa e imobilizada nas Etapas 1, 2 e 3, nos ensaios complementares e nos exames microbiológicos, permitiram concluir que:

- Na estratégia inicial (Etapa 1), a carga nitrogenada aplicada no sistema chegou a 0,15 $\mathrm{kgN}-\mathrm{NH}_{4}{ }^{+} \cdot \mathrm{m}^{-3} \cdot$ dia $^{-1}$ e a remoção média de nitrogênio foi de $65 \pm 27 \%$, alcançando, em alguns casos, eficiência máxima superior a 90\%. A desnitrificação endógena se mostrou viável. Houve o acúmulo de nitrito na fase nitrificante. Aproximadamente $50 \%$ do produto da oxidação do nitrogênio amoniacal se deu a nitrito e os outros $50 \%$ se deu basicamente a nitrato. A nitrificação só ocorreu efetivamente quando os ácidos voláteis presentes no sistema eram consumidos. A melhor faixa de vazão de ar encontrada para nitrificar eficientemente foi de 8 a 9 L.min ${ }^{-1}$. A alta concentração de biomassa no sistema (aproximadamente 8 gSVT. $l^{-1}$ ) exigia uma quantidade de ar fornecida muito grande.

- Na Etapa 2, a carga nitrogenada aplicada no sistema com biomassa suspensa chegou à $0,61 \mathrm{kgN}-\mathrm{NH}_{4}{ }^{+} \cdot \mathrm{m}^{-3} \cdot \mathrm{dia}^{-1}$. A média de eficiência de desnitricação foi de $42 \pm 21 \%$. A desnitrificação completa só se deu após 6 a 9 horas depois do tempo previsto para a fase anóxica (6 horas). Com aproximadamente 40\% a menos de biomassa em relação à Etapa 1 anterior, a melhor faixa de vazão de ar encontrada para nitrificar eficientemente foi de 5 a $6 \mathrm{~L} \cdot \mathrm{min}^{-1}$. A eficiência média de nitrificação foi de aproximadamente $85 \pm 12 \%$, alcançando, em muitos casos, eficiência máxima de quase 100\%. Aproximadamente $98 \%$ do produto da nitrificação se deu até nitrito. A concentração de nitrato foi despresível. Não foi verificada vantagem na adição de afluente na fase desnitrificante, devido provavelmente a efeitos de toxicidade do nitrito (média superior à $200 \mathrm{mgN}-\mathrm{NO}_{2}{ }^{-}$) sobre os microrganismos desnitrificantes. 
- A carga nitrogenada aplicada no sistema com biomassa imobilizada na Etapa 3 chegou a $0,50 \mathrm{kgN}-\mathrm{NH}_{4}{ }^{+} \cdot \mathrm{m}^{-3} \cdot \mathrm{dia}^{-1}$, com eficiência média de nitrificação de $94 \pm 9 \%$, alcançando, em muitos casos, $100 \%$ de eficiência em até 6 horas. O produto principal da nitrificação foi o nitrito e a concentração de nitrato não superou $5 \%$ em relação à concentração de nitrito. A remoção média efetiva de nitrogênio na fase desnitrificante foi de aproximadamente $72 \pm 13 \%$ em, no máximo, 6 horas. Em muitos casos, obtevese à remoção completa de $100 \%$ de nitrato e nitrito em tempo inferior a 6 horas. Este reator mostrou-se menos sensível a efeitos de toxicidade e favoreceu o processo nitrificante e desnitrificante, provavelmente devido à estrutura do biofilme desenvolvida em suporte inerte.

- A modelagem cinética de perfis temporais de concentração, de modelos convencionais e não convencionais de remoção de nitrogênio, foi uma ferramenta importante na interpretação dos resultados obtidos. Através dos modelos propostos foi possível identificar processos não convencionais de remoção de nitrogênio, atribuídos aqui à ANAMMOX e também fenômenos como desnitrificação em fase aeróbia.

- A utilização de técnicas de microsensores mostrou-se interessante para avaliação do melhor material suporte a ser utilizado em sistema nitrificante/desnitrificante. $\mathrm{O}$ material suporte escolhido foi carvão mineral por apresentar zonas aeróbias e anaeróbias no interior do biofilme, além de não propiciar um crescimento excessivo do biofilme.

- Os compostos de enxofre não tiveram grande influência na nitrificação. Verificou-se em alguns casos que o sulfeto pode ter sido utilizado para o processo desnitrificante.

Os resultados demonstram que a remoção de nitrogênio, com períodos aeróbio e anóxico, em ciclo de 12 horas, mostrou-se viável principalmente no reator com biomassa imobilizada. Nesse reator, conclui-se que a adição de parcela do afluente foi fundamental para a aceleração do processo desnitrificante, no entanto, é necessário que este afluente adicionado contenha material orgânico prontamente degradável suficiente para a desnitrificação heterotrófica. 


\section{Capítulo 6}

\section{Referências}

\subsection{REFERÊNCIAS}

ABELING, U.; SEYFRIED, C.F. (1992). Anaerobic-aerobic treatment of high-strength ammonium wastewater. Nitrogen removal via nitrite. Water Science Technology. v.26, n.5-6, pp.1007-15.

AHN, Y.H. (2006). Sustainable nitrogen elimination biotechnologies: A review. Process Biochemistry. v.41, n.8. pp. 1709-1721.

ANDERSSON I.C.; \& LEVINE J.S. (1986). Relative rates of $\mathrm{NO}$ and $\mathrm{N}_{2} \mathrm{O}$ production by nitrifiers, denitrifiers and nitrate respirers. Applied and Environmental Microbiology, v.51, pp.938-945.

ANTHONISEN, A.C., LOEHR, R.C., PRAKASAM, T.B.S. E SRINATH, E.G. (1976). Inhibition of nitrification by ammonia and nitrous acid. Journal of Water Pollution Control Federation. V.48, pp.835-852.

ARAÚKO, J.C; TÉRAN F.C; OLIVEIRA, R.A; NOUR, E.A.AÇ MONTENEGRO, M.A.P; CAMPOS, J.R. E VAZOLLER, R.F. (2003). Comparison of hexamethyldisilazane and critical point drying treatments for SEM analysis of anaerobic biofilms and granular sludge. Journal of Electron Microscopy. v.52, pp.429-433.

CARUCCI, A.; RAMADORI, R.; ROSSETTI, S. e TOMEF, M.C. (1996). Kinetics of denitrification reactions in single sludge systems. Water Research. v.30, n.1, pp.51-56.

CASTIGNETTI D.; GUNNER H.B. (1980). Sequential nitrification by an Alcaligenes sp. and Nitrobacter agilis. Canadian Journal of Microbiology, v.26, pp.1114-1119.

ÇEÇEN, F.; GÖNENÇ I.E. (1994). Nitrogen removal characteristics of nitrification and denitrification filters. Water Science and Technology. v.29, n.10-11, pp 409-416.

ÇEÇEN, F.; GÖNENÇ I.E. (1995). Criteria for nitrification and denitrification of highstrength wastes in two upflow submerged filters. Water Environment Research. v.67, n.2, pp. 132-142.

DANIEL, L.M.C. (2005). Remoção de nitrogênio via nitrito em reator operado em bateladas seqüenciais contendo biomassa imobilizada e aeração intermitente. Tese (Doutorado) - Escola de Engenharia de São Carlos, Universidade de São Paulo. 
DEBASTIANI W.G. (2002). Resolução numérica utilizando o método Runge-Kutta 4 em Microsoft Excel ${ }^{\circledR}$ - http://www.geocities.com/giorgiodebastiani/

DRISCOLL C.T; BISOGNI J.J. (1978). The use of sulfur and sulfide in packed bed reactors for autotrophic denitrification. Journal Water Pollution Control Federation, v.50, pp.569-577.

FDZ-POLANCO F.; FDZ-POLANCO M.; FERNANDEZ N.; URUENA M.A.; GARCIA P.A.; VILLAVERDE S. (2001). New process for simultaneous removal of nitrogen and sulphur under anaerobic conditions. Water Research, v.35, n.4, pp.1111-4.

FURUMAI, H., TAGUI, H., FUJITA, K. (1996). Effects of pH and alkalinity on sulphurdenitrification in a biological granular filter. Water Science Technology. v.34, pp.355362 .

FUX, C.; LANGE, K.; FAESSIER, A.; HUBER, P.; GRUENIGER, B.; SIEGRIST, H. (2003). Nitrogen removal from digester supernatant via nitrite - SBR or SHARON? Water Science Technology. v.48, n.8, pp.9-18.

GILLIAN, D.; SPEKSNIJDER, A.; ZWART, G. E RIDDER, C. (1998) Genetic diversity of the biofilm covering Montacuta ferruginosa (Mollusca, Bivalvia) as evaluated by denatruring gradient gel electrophoresis analysis and cloning of PCR-Amplified gene fragments coding for 16S rRNA. Applied Environmental Microbiology. v.64(9), pp. 3464-3472.

GÒMEZ-HERNANDEZ, J., LEMA-RODICIO, J. M e MÉNDEZ-PAMPÍN, J. R. (1995). La nitrificaciòn biológica con cultivos axénicos o lodos activados. Ciencia. pp. 507-523.

GOMMERS, P.J.F.; BIJLEVELD, W.; KUENEN, J.G. (1988). Simultaneous Sulfide and Acetate Oxidation in a Denitrifying Fluidized Bed Reactor I: Start-Up and Reactor Performance. Water Research. v.22, n.9, pp. 1075-1083.

GRIFFITHS, R.I.; WHITELEY, A.S. E O'DONNELL, A.G. (2000). Rapid method for coextration of DNA from natural enviroments for analysis of ribossomal DNA and rRNA-based microbiological community composition, Applied and Environmental Microbiology. v.66(12). pp.5488-5491.

GUPTA, A.B. (1997). Thiosphaera pantotropha: a sulfur bacterium capable of simultaneous heterotrophic nitrification and aerobic denitrification. Enzyme and Microbial Technology. v.21, pp.589-595.

GUT, L.; PLAZA, E.; HUTMAN, B. (2007). Assessment of a two-step partial nitritation/Anammox system with implementation of multivariate data analysis. Chemometrics and Intelligent Laboratory Systems.v.86, pp. 26-34.

HENZE, M.; HARREMOES, P.; JANSEN, J.L.C.; ARVIN, E. (1997). Wastewater treatment, 2.ed. Germany, Springer. 
HENZE M., HOLM KRISTENSEN G. AND STRUBE R. (1994). Rate-capacity characterization of wastewater for nutrient removal processes. Water Science and Technology. v.29, pp.101-107.

HUNIK, J.H.; MEIJER, H.J.G.; TRAMOER, J. (1993). Kinetcs of Nitrobacter agilis at extreme substrate, product and salt concentrations. Applied and Microbiology Biotechnology, v.40 pp.442-448.

IAMAMOTO, C.Y. \& FORESTI, E. (2005). Nitrificação e desnitrificação em reator operado em batelada seqüencial tratando águas residuárias com alta concentração de nitrogênio amoniacal. Anais do IV Seminário do Projeto Temático: Desenvolvimento, Análise, Aprimoramento e Otimização de Reatores Anaeróbios para Tratamento de Águas Residuárias. Escola de Engenharia de São Paulo, São Carlos, SP.

IAMAMOTO, C.Y. (2006). Remoção de nitrogênio de água residuárias com elevada concentração de nitrogênio amoniacal em reator contendo biomassa em suspensão operado em bateladas seqüenciais e sob aeração intermitente. Tese (Doutorado) Escola de Engenharia de São Carlos, Universidade de São Paulo.

JENKINS, D.; RICHARD, M.G.; DAIGGER, G.T. (2003). Manual of the causes and control of activated sludge bulking, foaming and other solids separation problems. $3^{\text {rd }}$ ed. Boca Raton. Lewis Publishers.

JETTEN, M.S.M.; LOGEMANN, S.; MUYZER, G.; ROBERTSON, L.A; DE VRIES, S.; VANLOOSDRECHT, M.C.M.; KUENEN, J.G. (1997). Noval principles in the microbial conversion of nitrogen compounds. Applied Water Management Research (STOWA), v.71, pp.75-93.

JETTEN, M.S.M.; SLIEKERS, A.O.; THIRD, K.A.; ABMA, W.; KUENEN, J.G. (2003). Canon e anammox in a gas-lift reactor. FEMS Microbiology Letters. v.218, pp.339344.

KALYUZHNYI S, GLADCHENKO M, MULDER A, VERSPRILLE B. (2006). DEAMOX-new biological nitrogen removal process based on anaerobic ammonia oxidation coupled to sulphide-driven conversion of nitrate into nitrite. Water Research. v.40. pp. 3637-45.

KIMURA, K., NAKAMURA, M., WATANABE, Y. (2002). Nitrate removal by a combination of elemental sulphur-based denitrification and membrane filtration. Water Research. v.36 (7), pp.1758-1766.

KLEEREBEZEM, R., MÉNDEZ, R. (2002). Autotrophic denitrification for combined hydrogen sulphide removal from biogas and post-denitrification. Water Science and Technology. v.45 (10), pp.349-356.

KRISHNAKUMAR, B., MANILAL, V.B. (1999). Bacterial oxidation of sulphide under denitrifying conditions. Biotechnol. Lett. v.21, pp.437-440. 
KUAI, L.;VERSTRAETE, W. (1998). Ammonium Removal by the Oxygen-Limited Autotrophic Nitrification-Denitrification System. Applied and Environmental Microbiology. v.64, n.11, pp. 4500-4506.

KUBA, T., MURNLEITNER, E., VANLOOSDRECHT, M.C.M., HEIJNEN, J.J., (1996). A metabolic model for biological phosphorus removal by denitrifying organisms. Biotechnol. Bioeng. v.52 (6), pp.685-695.

KUENEN J.G.; ROBERTSON L.A. (1987). Ecology of nitrification and denitrification. In: J. A. Cole and S. Ferguson (Eds.). The Nitrogen and sulfur cycles. Cambridge University Press Cambridge, UK, pp. 162-218.

LAMON, A.W. et al. (2007). Microsensores com tecnologia nacional. Ciência Hoje. v.40, n.235, pp.64-66.

LEWANDOWSKI, Z.; WALSER, G.; CHARACKLIS, W.G. (1991). Reaction kinetics in biofilms. Biotechnology and Bioengineering. v.38, n.8, pp. 877-882.

MADIGAN, M. T.; MARTINKO, J. M.; PARKER, J. (1997). Brock biology of microorganisms. New Jersey. Eighth Edition. Prentice Hall.

MASZENAN, A.M.; SEVIOUR, R.J.; PATEL, B.K.C.; REES, G.N.; MCDOUGALL, B.M. (1997) Amaricoccus gen. nov., a Gram-Negative Coccus Occurring in Regular Packages or Tetrads, Isolated from Activated Sludge Biomass, and Descriptions of Amaricoccus veronensis sp. nov., Amaricoccus tamworthensis sp. nov., Amaricoccus macauensis sp. nov., and Amaricoccus kaplicensis sp. nov. Internacional journal of Systematic Bacteriology. v.47, pp.727-734.

MASZENAN, A.M.; SEVIOUR, R.J.; PATEL, B.K.C.; SCHUMANN, P.; REES, G.N. (1999). Tessaracoccus bendigoensis gen. nov., sp. nov.,a Gram-positive coccus occurring in regular packages or tetrads, isolated from activated sludge biomass. Internacional journal of Systematic Bacteriology. v.49, pp.459-468.

MINO, T., VAN LOOSDRECHT, M.C.M., HEIJNEN, J.J., (1998). Microbiology and biochemistry of the enhanced biological phosphate removal process. Water Research. v.32 (11), pp.3193-3207.

MORAES, E.M.; ADORNO, M.A.T.; ZAIAT, M.; FORESTI, E. (2000). Determinação de ácidos voláteis por cromatografia gasosa em efluentes de reatores anaeróbios tratando resíduos líquidos e sólidos. In: OFICINA E SEMINÁRIOS LATINO AMERICANO DE DIGESTÃO ANAERÓBIA, 6., 2000, Recife-PE. Anais. Editora Universitária UFPe, pp. 2813-2823.

MULDER, A.; VAN DE GRAAF, A.A.; ROBERTSON, L.A.; KUENEN, J.G. (1995). Anaerobic ammonium oxidation discovered in a denitrifying fluidized bed reactor. FEMS Microbiology Ecology. v.16, pp.177-184.

MULDER, J.W., VAN KEMPER, R. (1997). N-removal by SHARON. Water Quality International, v.2, pp.20-31. 
MULDER, A. (2003). The quest for sustainable nitrogen removal technologies. Water Science and Technology, v.48(1), pp.67-75.

MUNCH E.V.; LANT M.P.; KELLER M.J. (1996). Simultaneous nitrification and denitrification in bench-scale sequencing batch reactors. Water Research. v.30,n.2,pp. 277-284.

NEDOVIĆ, V.; WILLAERT, R. (2005). Applications of Cell Immobilization Biotechnology. Springer. pp.566, ISBN 1402032293.

NIELSEN M.; BOLLMANN A.; SLIEKERS A.O.; JETTEN M.S.M.; SCHMID M.; STROUS M.; SCHMIDT.I.; LARSEN L.H.; NIELSEN L.P.; REVSBECH N.P. (2005). Kinetics, diffusional limitation and microscale distribution of chemistry and organisms in a CANON reactor. FEMS Microbiol Ecology. v.51, n.2, pp.247-56.

NIELSEN, A.T.; LIU, W.T.; FILIPE, C.; GRANDY, L.; MOLIN, S.; STAHL, D.A. (1999). Identification of a novel group of bacteria in sludge from a deteriorated biological phosphorous removal reactor. Applied and Environmental Microbiology. v.65(3) pp.1251-1258.

OEHMEN, A..; LEMOS, P.C.; CARVALHO, G.; YUAN, Z.; KELLER, J.; BLACKALL, L.L.; REIS, M.A. (2007). Advances in enhanced biological phosphorus removal: from micro to macro scale. v.41(11), pp. 2271-300.

PATHAK, B.K.; KAZAMA, F.; SAIKI, Y.; SUMINO, T. (2007). Presence and activity of anammox and denitrification process in low ammonium-fed bioreactors. Bioresource Technology. v.98, pp. 2201-2206.

PATUREAU D.; GODON J.J.; DABERT P.; BOUCHEZ T.; BERNET N.; DELGENES J.P.; MOLETTA R. (1998). Microvirgula aerodenitrificans gen. nov., sp. nov., a new gramnegative bacterium exhibiting co-respiration of oxygen and nitrogen oxides up to oxygen-saturated conditions. International Journal of Systematic Bacteriology. v.48, pp.775-782.

PHILIPS, S., LAANBROEK, H.J. \& VERSTRAETE, W. (2002). Origin, causes and effects of increased nitrite concentrations in aquatic environments. Reviews in Environmental Science and Bio/Technology. v.1, pp.115-141.

POCHANA, K.; KELLER, J. (1999). Study of factors affecting simultaneous nitrification and denitrification (SND). Water Science and Technology, v39, n.6, pp.61-68.

PRAKASAM, T.B.S. \& LOEHR, R.C. (1972). Microbial nitrification and denitrification in concentrated wastes. Water Research. v.6, pp.859-869.

PROSSER, J. (1989). Autotrophic nitrification in bacteria. Em: ROSE, A. e TEMPEST, D. Advances in microbial physiology. Academic Press, Londres, pp. 125-181.

PUZNAVA, N.; PAYRAUDEAU, M.; THORNBERG, D. (2001). Simultaneous nitrification and denitrification in biofilters with real time aeration control. Water Science and Technology. v.43, n.1, pp.269-276. 
RANDALL, C.W.; BUTH, D. (1984). Nitrite buildup in activated sludge resulting from combined temperature and toxicity effects. Water Pollution Control Federation annual conference. v.56, n.9, pp. 1045-1049.

RANDALL C. W., BARNARD J. L. AND STENSEL H. D. (1992). Design and retrofit of wastewater treatment plants for biological nutrient removal. Water Quality Management Library, v.5.

ROBERTSON L.A.; KUENEN J.G. (1988). Heterotrophic nitrification in Thiosphaera pantotropha —oxygen uptake and enzyme studies. Journal of General Microbiology, v.134, pp 857-863.

ROS, M. (1995). Denitrification kinetics ina an activated sludge system. Water Science Technology. Vol 32. No. 9-10. pp. 323-330.

SCHAUBER, R. \& KRÖGER, A. (1993). Bacterial Sulphur Respiration. Archives of Microbiology. v.159, pp. 491-497.

SCHMIDT, I. et al.(2003). New concepts of microbial treatment processes for the nitrogen removal in wastewater. FEMS Microbiology Reviews. v.27, n.4, pp. 481-492.

SHOLTEN E.; LUKOW, T.; AULING G.; KROPPENSTEDT R.M.; RAINEY F.A.; DIEKMANN H. (1999). Thauera mechernichensis sp. nov., an aerobic denitrifier from a leachate treatment plant. International Journal of Systematic Bacteriology. v.49, pp.1045-1051.

SLIEKERS, A.O.; DERWORT, N.; CAMPOS GOMES, J.L.; STROUS, M.; KUENEN, J.G; JETTEN, M.S.S. (2002). Completely autothrophic nitrogen removal over nitrite in one single reactor. Water Research, v.36, pp.2475-2482.

SOARES, M.I.M. (2002). Denitrification of groundwater with elemental sulphur. Water Research. v.36 (5), pp.1392-1395.

STANDARD METHODS FOR THE EXAMINATION OF WATER AND WASTEWATER (1998). 19 th ed. Amer. Public Health Assoc., Americ. Water Works Association, Water Pollution Control Federation, Washington, D.C., 1134p.

SUDIANA, I.M., MINO, T., SATOH, H., NAKAMURA, K., MATSUO, T. (1999). Metabolism of enhanced biological phosphorus removal and non-enhanced biological phosphorus removal sludge with acetate and glucose as carbon source. Water Science Technology. v.39 (6), pp.29-35.

SUMINO, T.; ISAKA, K.; IKUTA, H.; SAIKI, Y. E YOLOTA, T. (2006). Nitrogen removal from wastewater using simultaneous nitrate reduction and anaerobic ammonium oxidation in single reactor. Journal of Bioscience and Bioengineering. v.102, n.4, pp. 346-351. 
SUTHERSAN S.; GANCZARCZYK, J.J. (1986). Inhibition of nitrite oxidation during nitrification. Some observations. Water pollution research journal of Canada. v.21, $\mathrm{n}$. 2, pp. 257-266.

TROUVE C.; CHAZAL P.M.; GUEROUX B.; SAUVAITRE N. (1998). Denitrification by new strains of thiobacillus denitrificans under non-standard physicochemical conditions. effect of temperature, ph, and sulphur source. Environmental Technology, v.19, n.6, pp. 601-610.

U. S. EPA (1987). Technology Transfer Design Manual Phosphorus Removal. USEPA/625/187/001 CERI Cinn., OH 45268.

VAN DE GRAAF, A.A.; BRUIJIN, P.; ROBERTSON, L.A.; JETTEN, M.; KUENEN, J.G. (1996). Autotrophic Growth of Anaerobic Ammonium-oxidizing micro-organismsin a fluidized bedreactor. Microbiology, v.142, pp.2187-2196.

VAN HAANDEL, A.; MARAIS, G. (1999). O comportamento do sistema de lodo ativado, teoria e aplicações para projetos e operação. Campina Grande-PB. Epgraf.

VAN LOOSDRECHT, M. C. M.; JETTEN, M. S. M. (1998). Microbiological conversions in nitrogen removal. Water Science Technology. Vol 38. No. 1. pp. 1-7.

VAN NIEL E.W.J.; ROBERTSON L.A.; KUENEN J.G. (1987). Heterotrophic nitrification in denitrifying bacteria. Proceedings of 4th European Congress on Biotechnology, v.3, pp.363.

VESTRAETE, W.; PHILIPS, S. (1998). Nitrification-denitrification processes and technologies in new contexts. Environmmental Pollution. v.102, pp.717-72.

VILLAVERDE, S.; GARCIA, E.P.A.; LACALLE, M.L.; FERNANDEZ-POLANCO, F. (2000). New operational strategy for SBR technology for total nitrogen removal from industrial wastewaters highly loaded with nitrogen. Water Science Technology. v.41, n.12.pp.85-93.

VILLAVERDE, S. (2004). Recent developments on biological nutrient removal processes for wastewater treatment. Reviews in Environmental Science and Biotechnology. v.3, n.2, pp. 1572-9826.

VOLKS, M.; ADAM, C.; LESJEAN, B.; GNIRSS, R.; KRAUME, M. (2005). Enhanced postdenitrification without addition of an external carbon source in membrane bioreactors. Water Research. v.39, pp. 3360-3368.

VON MÜNCH, E., LANT, P., KELLER, J., (1996). Simultaneous nitrification and denitrification in bench-scale sequencing batchreactors. Water Research. v.30,pp.277-284.

WANG, Y.; HUANG, X.; YUAN, Q. (2005). Nitrogen and carbon removals from food processing wastewater by an anoxic/aerobic membrane bioreactor. Process Biochemistry. v.40, pp. 1733-1739. 
YANG, L.; ALLEMAN, J.E. (1992). Investigation of batchwise nitrite build-up by an enriched nitrification culture. Water Science Technology. v.26, n.1-12. pp.997-1005.

ZHANG, T.C., LAMPE, D.G. (1999). Sulfur:limestone autotrophic denitrification processes for treatment of nitrate-contaminated water: batch experiments. Water Research.v.33 (3), pp.599-608. 